ISSN 2391-5110

vol. $13 / 2018$
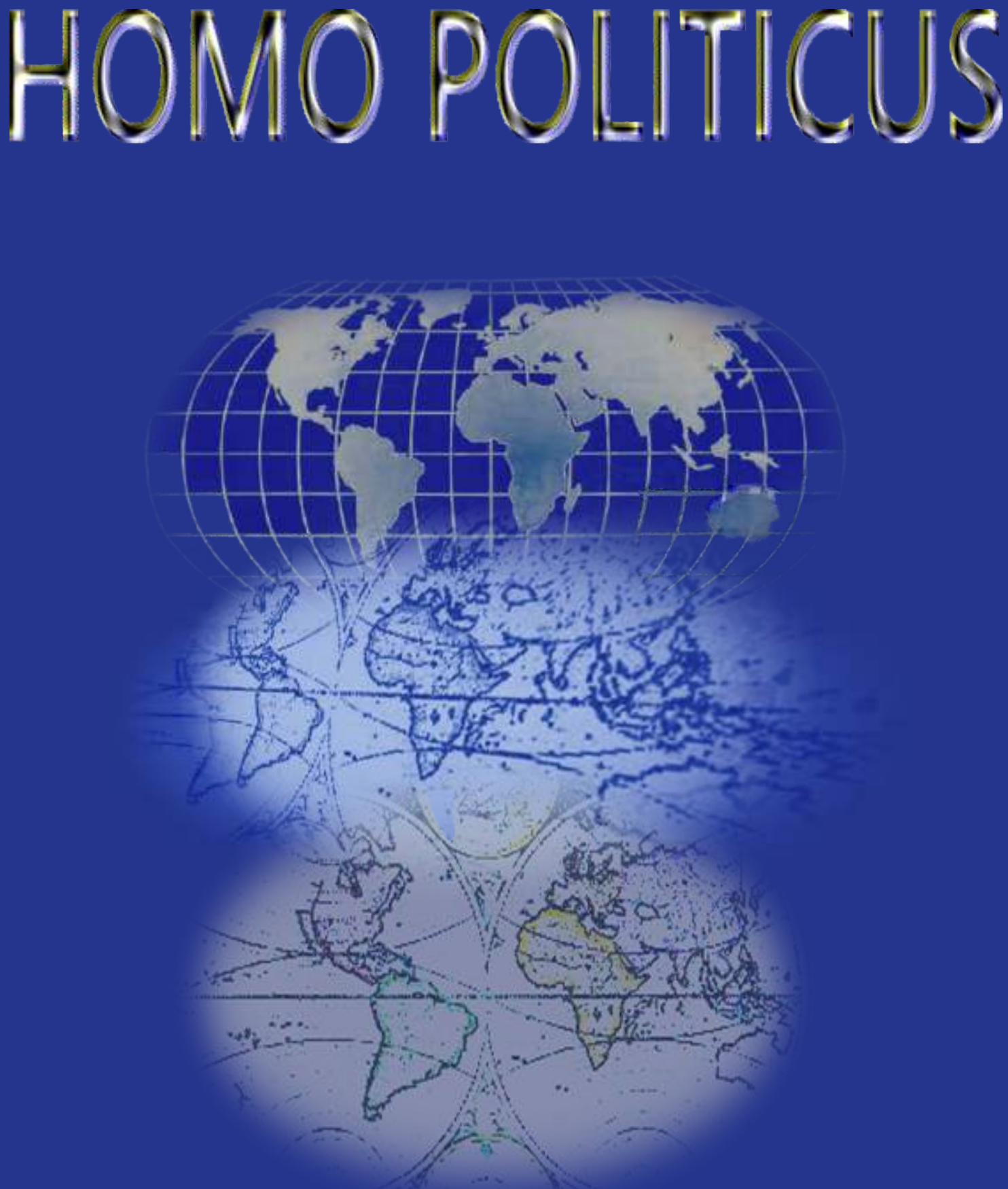
ROCZNIK POLITOLOGICZNY

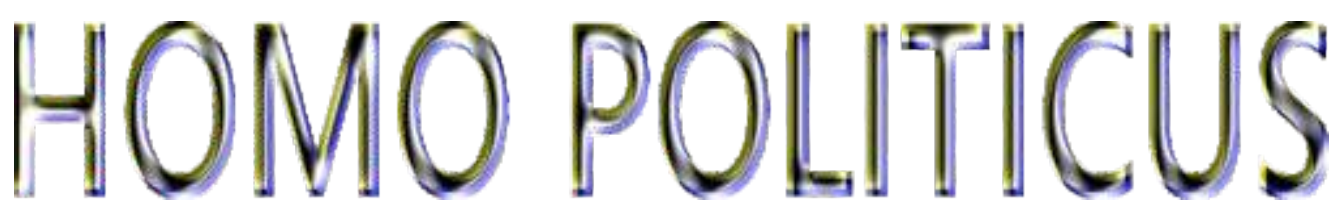

ISSN 2391-5110

vol. 13/2018 


\section{Redaktor naczelny \\ prof. dr hab. Andrzej K. Piasecki \\ Redakcja tematyczna \\ dr Radosław Kamiński (sekretarz) \\ Redakcja językowa \\ Ph. D. Michael Fleming (AHE) (j. angielski)}

\section{Rada programowa}

prof. dr hab. Zbigniew Rau (UŁ)

prof. dr hab. Stanisław Sulowski (UW)

prof. dr hab. Konstanty Adam Wojtaszczyk (UW)

prof. dr hab. Marek Żmigrodzki (UMCS Lublin)

prof. dr hab. Arkadiusz Żukowski (UWM Olsztyn)

prof. dr hab. Katarzyna Żukrowska (SGH)

dr hab. prof. WAT Janusz Świniarski (WAT)

\section{Redaktor odpowiedzialny za vol. 13/2018 \\ dr Radosław Kamiński}

\section{Recenzenci}

Lista recenzentów publikowana jest na stronie internetowej czasopisma www.homopoliticus.ahe.lodz.pl

\section{Redakcja czasopisma „Homo Politicus”}

Akademia Humanistyczno-Ekonomiczna w Łodzi

90-212 Łódź, ul. Sterlinga 26

tel. 0-42 6315070

(C) Copyright by Akademia Humanistyczno-Ekonomiczna w Łodzi Łódź 2018

ISSN 1896-1770

(wersja drukowana jest wersją pierwotną)

Wersja elektroniczna

e-ISSN 2391-5110

(numery stron zgodne $\mathrm{z}$ wersją drukowaną)

Korekta Iwona Cłapińska

Skład DTP Monika Poradecka

Wydawnictwo Akademii Humanistyczno-Ekonomicznej w Łodzi

90-212 Łódź, ul. Sterlinga 26

tel. +426315908

wydawnictwo@ahe.lodz.pl

www.wydawnictwo.ahe.lodz.pl 


\section{Spis treści}

Waldemar Janosiewicz

Samorząd terytorialny w Polsce - zarys historyczny

Andrzej Piasecki, Paulina Rus

Ekonomia społeczna w samorządzie terytorialnym

Sylwia Rapicka

Pomówienie w polityce. Wybrane aspekty prawne i empiryczne

Emilia Szczęsna

Unijne przepisy o ochronie danych osobowych w jednostkach samorządu terytorialnego

Jakub Olech

Modele sądowej kontroli administracji - próba syntezy

Lilija Twardosz

Wdrożenie przepisów UE dotyczących spraw spadkowych do porządku prawnego Rzeczypospolitej Polskiej

Małgorzata Kmak

Kontrola administracji publicznej - ujęcie systemowe (wybrane aspekty)

Anna Janus

Zarządzanie w sektorze publicznym - wybrane zagadnienia

Mateusz Bodzek

Zielone i społecznie odpowiedzialne zamówienia publiczne jako narzẹdzie zrównoważonego rozwoju transportu publicznego 
Marta Wysogląd

Realizacja Zintegrowanych Inwestycji Terytorialnych na obszarze aglomeracji

jeleniogórskiej przez jednostki samorządu terytorialnego

Piotr Kuźniak

Opieka wytchnieniowa - uwarunkowania rozwoju usług na poziomie lokalnym 


\section{Content}

Waldemar Janosiewicz

Territorial local government in Poland - an historical overview

Andrzej Piasecki, Paulina Rus

Social economy in local government

Sylwia Rapicka

Defamation in politics. Selected legal and empirical aspects

Emilia Szczesna

EU regulations on the protection of personal data in local government units

Jakub Olech

Models of judiciary control over administration - a synthetic approach.

Lilija Twardosz

The adoption of EU laws regarding inheritance into the law of the Republic of Poland

Małgorzata Kmak

Public administration control - system approach (selected aspects)

Anna Janus

Management in the public sector - selected issues

Mateusz Bodzek

Green and socially responsible public procurement as a tool for the sustainable development of public transport 
Marta Wysogląd

Implementation of Integrated Territorial Investments in the area

of the Jelenia Góra Agglomeration by local government units

Piotr Kuźniak

Respite care - determinants of the development of services at the local level 


\section{Samorząd terytorialny w Polsce - zarys historyczny}

Samorząd terytorialny jest w Polsce trwałym elementem ustroju państwa. Historia samorządu terytorialnego na naszych ziemiach sięga czasów średniowiecza. W dziejach każdego narodu wydarzeniem fundamentalnym było kształtowanie się państwa. Najstarszą formą osiadłego trybu życia, za sprawą rozwoju rolnictwa, stawała się wieś. Wraz z wyodrębnianiem się grup Słowian na przełomie V i VI wieku tworzyły się wspólnoty rodowe. Opole było pierwotną wspólnotą terytorialno-osadniczą, z której z czasem powstała wieś. Okres pierwszych Piastów to proces przekształcania się struktury rodowo-plemiennej w system prowincjonalny, tworzono okręgi grodowe z komesami grodowymi na czele, a opola utrzymywane były przez władze centralne jako jednostki pomocnicze. Na przełomie wieków XII i XIII opola zastąpiono organizacjami kasztelańskimi, kasztelani byli urzędnikami mianowanymi i pozostawali najważniejszymi przedstawicielami władzy książęcej ${ }^{1}$.

W Polsce dzielnicowej wraz z osadnictwem na prawie niemieckim (XIII wiek) pojawił się urząd sołtysa, który z czasem stał się i jest do dnia dzisiejszego jednym z najbardziej charakterystycznych elementów społeczności wiejskiej. W tym samym czasie w mieście zaistniała instytucja wójta, ale w ciągu XV stulecia instytucję wójta przeniesiono na wieś, i w ten sposób sołtys (od XIII wieku), a wójt (przełom XV i XVI wieku) stali się liderami społeczności wiejskich. Urzędowi sołtysa towarzyszyła instytucjonalna forma powstającego stopniowo samorządu terytorialnego - ława wiejska. W XVI wieku zniesiono dziedziczność urzędu sołtysa. Panowie wykupywali dziedziczne sołectwa, a na czele wsi stawiali wyznaczonego przez siebie wójta. Urząd sołtysa tracił znaczenie na rzecz urzędu wójta².

${ }^{1}$ J. Hebda, Z soltysem i wójtem przez wieki. Opowieść o dziejach urzędu soltysa i wójta w Polsce, Muzeum Historii Polskiego Ruchu Ludowego, Tarnów-Warszawa 2016, s. 25-45.

2 Tamże, s. 47-76. 
W czasach zaborów, niezależnie od zaborowego zróżnicowania prawa, okrzepł samorząd terytorialny. Zaborcy wkomponowali urząd sołtysa i wójta w system administracji państwa na najniższym szczeblu. Po uwłaszczeniu samorząd wiejski wzmocnił swoje struktury i znaczenie, wielu sołtysów i wójtów rozwijało karierę, przechodząc do polityki państwowej. W czasach II RP do przestrzeni publicznej sołectw i gmin zaczęły przenikać ideologie partii chłopskich („Piast”, Stronnictwa Ludowego) ${ }^{3}$.

W plemiennych państwach słowiańskich instytucją pozwalającą rozwiązywać kwestie dotyczące ogółu był wiec, czyli zgromadzenie starszyzny plemiennej w celu podjęcia decyzji dotyczących na przykład spraw bezpieczeństwa czy wyboru władcy. W średniowiecznej Polsce od czasownika wietati ${ }^{4}$ (mówić) określano radę możnych decydującą o sprawach dzielnicy, szczególnie w okresie rozbicia feudalnego. W tym czasie sprawy państwowe rozpatrywano na lokalnych zjazdach feudalnych: wiecach, kolokwiach, rokach oraz roczkach sądowych, które w XIV wieku przekształciły się w sejmiki'. Sejmiki ziemskie, czyli zjazd szlachty danej ziemi od schyłku XIV wieku pozostawał podstawowym organem samorządu szlacheckiego obejmującym określone terytorium. Sejmiki generalne były organem samorządu danej prowincji. Sejmiki podejmowały uchwały dotyczące między innymi wyznaczenia zakresu obowiązku chłopów, kar za zbiegostwo chłopów, wysokość dziesięciny uzgadniały z przedstawicielami Kościoła. Sejmiki dysponowały własnym skarbem. Część funduszy przeznaczano na opłacanie wysyłanych do króla posłów ${ }^{6}$.

Przywilej koszycki nadany w 1374 roku przez króla Ludwika Węgierskiego pozwalał szlachcie wpływać na wybór następcy tronu. Król nie tylko zmniejszył wysokość podatków dla szlachty, ale również zobowiązał się do niewprowadzania nowych podatków bez zgody stanu szlacheckiego. Ponadto zwolnił szlachtę z obowiązku budowy i naprawy zamków obronnych i z obowiązku utrzymywania króla podczas jego podróży po kraju. Dokument nakładał na szlachtę obowiązek obrony kraju, ale też obiecywał wynagrodzenie za udział w wyprawach zagranicznych. Na urzędy grodzkie i państwowe mieli być powoływani tylko Polacy. Przywilej ograniczał częściowo władzę króla na rzecz szlachty. Przywilej koszycki zapoczątkował niebezpieczne dla ustroju Polski praktyki nadawania przez kolejnych władców przywilejów zwiększających wpływ stanu szlacheckiego na prawodawstwo. Obejmujący rządy w 1386 roku Władysław Jagiełło wydał przywileje w Jedlni (1430) i Krakowie (1433). W celu zapewnienia panowania dynastii Jagiellonów w Polsce król obiecał szlachcie nienaruszalność osobistą oraz wyłączność na obejmowanie wyższych stanowisk kościelnych ${ }^{7}$.

Wydane w czasie wojny trzynastoletniej (1454) statuty cerekwicko-nieszawskie nadawały sejmikom funkcje ustawodawcze ${ }^{8}$. Znacząco ograniczały władzę króla na rzecz uprawnień sejmików generalnych i ziemskich. Król bez zgody sejmików szlacheckich nie miał prawa zwołać pospolitego ruszenia, nałożyć nowych podatków, zawierać sojuszy czy wydawać nowych ustaw. Statuty wprowadzały również zakaz łączenia urzędów kasztelana i woje-

\footnotetext{
${ }^{3}$ Tamże, s. 602-605.

${ }^{4}$ A. Brückner, Stownik etymologiczny języka polskiego, Wiedza Powszechna, Warszawa 1985, s. 614.

${ }^{5}$ H. Samsonowicz, Historia Polski do roku 1795, WSiP, Warszawa 1985, s. 106.

${ }^{6}$ Encyklopedia szkolna. Historia, WSiP, Warszawa 1995, s. 587.

7 Tamże, s. 480-481.

8 Tamże, s. $480-481$.
} 
wody z urzędem starosty. Król nie miał prawa zastawiania starostw grodowych. Natomiast wojewodowie zostali wyposażeni w prawo ustanawiania cenników na wyroby rzemieślnicze w miastach. Kasztelanom ograniczono kompetencje karno-sądowe i zlikwidowano sądy kasztelańskie. Cofnięto niektóre przywileje dla Żydów. Postanowienia statutów nieszawskich powtórzono i rozszerzono w przywileju piotrowskim z 1496 roku. W celu zdobycia zgody szlachty na udział w wyprawie do Mołdawii król Jan Olbracht dołożył do dotychczasowych przywilejów prawo kupowania i sprzedawania towarów za granicę bez opłacania cła. Dodatkowo na korzyść szlachty działały zakazy obejmowania urzędów i posiadania ziemi przez mieszczan oraz opuszczania wsi przez chłopów (w ciągu roku jeden chłop miał prawo przenieść się do miasta). Powyższe postanowienia uczyniły ze szlachty grupę wyjątkowo uprzywilejowaną pod względem politycznym i ekonomicznym9

Ukoronowaniem zdobyczy stanu szlacheckiego było ustanowienie za rządów Aleksandra Jagiellończyka (1505) konstytucji Nihil novi (łac. nic nowego), odtąd na potomne czasy nic nowego stanowionym być nie ma przez nas i naszych następców, bez wspólnego zezwolenia senatorów i posłów ziemskich, co by było ujmą i ku uciążeniu Rzeczypospolitej oraz ze szkodo i krzywdą czyjąkolwiek tudzież zmierzało ku zmianie prawa ogólnego i wolności publicznej"10. W ten sposób ukształtował się ustrój monarchii stanowej, w której w sprawowaniu władzy obok króla uczestniczył tylko i wyłącznie stan szlachecki. Pozostałe stany były bardzo ograniczone w swoich prawach (mieszczanie) lub ich zupełnie pozbawione (chłopi). Rzeczpospolita szlachecka funkcjonująca w latach 1454-1795 obejmuje trzy fazy ustrojowe: - demokrację szlachecką od daty nadania przywilejów cerekwicko-nieszawskich do zerwania sejmu zasadą liberum veto (1454-1652),

- oligarchię magnacką do sejmu konwokacyjnego (1652-1764),

- monarchię konstytucyjną do obalenia Konstytucji 3 maja (1764-1792) ${ }^{11}$.

Wprowadzony od 1493 roku zwyczaj zwoływania przez króla sejmu walnego ${ }^{12}$ miał ograniczyć wpływy magnaterii, a zwiększyć kompetencje średniej szlachty. Posłowie szlacheccy obradowali oddzielnie w izbie poselskiej, natomiast wcześniejsza rada królewska przekształciła się w senat. W rezultacie ukształtował się sejm o trzech stanach sejmujących; królu, senacie i izbie poselskiej. Najważniejszymi kompetencjami sejmu było uchwalanie podatków, zwoływanie pospolitego ruszenia, zawieranie pokoju i sojuszy, przyjmowanie poselstw dyplomatycznych. Sejm walny posiadał również uprawnienia dotyczące kontroli monarchy. Powstanie sejmu ograniczyło rolę sejmików szlacheckich i wpłynęło na zmianę ich funkcji. Sejmiki zachowały swoje uprawnienia w obrębie danej ziemi lub prowincji. Funkcjonowały jako sejmiki przedsejmowe, generalne, kapturowe i deputackie. Najważniejsze były przedsejmowe, gdyż ich zadaniem był wybór posłów danej ziemi na sejm walny. Najczęściej na jedno województwo przypadał jeden sejmik. W województwach dzielących się na ziemie każda z ziem miała swój sejmik. Były one zwoływane przez wojewodę lub starostę na podstawie uniwersału królewskiego na pewien czas przed zwołaniem sejmu walnego.

\footnotetext{
9 H. Samsonowicz, dz. cyt., s. 106-108.

10 Konstytucja Nihil novi (1505 r.), https:/historia.org.pl/2009/10/27/konstytucja-nihil-novi-1505-r/

11 Encyklopedia szkolna. Historia, dz. cyt., s. 625, 359, 231.

12 H. Samsonowicz, dz. cyt., s. 106-108.
} [dostęp: 31.10.2018]. 
W obradach sejmiku uczestniczyli magnaci, szlachta średnia, zagrodowa i gołota. Obrady prowadził wybierany przez nich marszałek. Tematem obrad sejmików przedsejmowych było wysłuchanie listu królewskiego dotyczącego powodów zwołania sejmu, wybór posłów na sejm i ułożenie im instrukcji poselskiej. Instrukcja zawierała zalecenia dla posłów w sprawie stanowiska, jakie mają zająć wobec problemów przedkładanych przez króla. Rzadziej dawano posłom swobodę działania tzw. zupełną mocą. Sejmiki generalne zbierały się dla: Małopolski w Nowym Mieście Korczynie, Wielkopolski w Kole, Mazowsza w Warszawie, Prus Królewskich w Malborku lub Grudziądzu, Litwy w Wołkowysku lub Słonimiu, Rusi w Sądowej Wiszni. Przedmiotem obrad było uzgodnienie wspólnego stanowiska prowincji wobec spraw rozstrzyganych na sejmie walnym. Po zakończeniu sejmu walnego zwoływano sejmiki relacyjne, na których posłowie składali szlachcie sprawozdanie ze swojej działalności na sejmie walnym. Zastanawiano się również nad sposobem realizowania uchwał podjętych przez sejm. Sejmiki relacyjne obradowały regularnie od 1589 roku. Sejmiki elekcyjne zajmowały się wyborem kandydatów na wakujące urzędy ziemskie. Od 1572 roku funkcjonowały sejmiki kapturowe, których zadaniem było przejęcie władzy w danej ziemi w okresie bezkrólewia i zapewnienie bezpieczeństwa na danym terenie. Sejmiki deputackie funkcjonowały od czasów utworzenia Trybunału Koronnego (1578), ich zadaniem był wybór deputatów trybunalskich. Uchwały sejmikowe zwane laudami od końca XVI wieku wprowadzano do ksiąg grodzkich. Znaczenie sejmików ziemskich wzrosło na przełomie XVII i XVIII wieku, kiedy podupadł sejm walny, a sejmiki stały się miejscem ścierania się różnych frakcji magnackich posługujących się swoją klientelą szlachecką. W drugiej połowie XVII wieku rozpoczął się okres rządów sejmikowych, które przejmowały znaczną część funkcji administracyjnych od coraz słabiej działających władz centralnych. Sejmiki uchwalały i ściągały podatki, decydowały o ich przeznaczeniu, administrowały częścią podatków państwowych, powoływały pod broń żołnierzy powiatowych i opłacały dowódców. Początkowo stosowana zasada jednomyślności była od drugiej połowy XVII wieku coraz częściej zrywana. Uprawnienia podatkowe sejmików ograniczały od 1717 roku postanowienia Sejmu Niemego. Sejm Niemy ograniczył też zakres uprawnień senatu i wprowadził zakaz tworzenia konfederacji. W XVIII wieku sejmiki ziemskie zostały zdominowane przez frakcje magnackie ${ }^{13}$.

Sejm walny zwoływany był przez króla, a w czasach bezkrólewia przez prymasa. Początkowo król zwoływał go, gdy zaszła potrzeba, a miejsce obrad nie było stałe. Po 1569 roku obrady odbywały się w Warszawie, natomiast od 1673 roku co trzeci sejm walny odbywał się w Grodnie. Od 1573 roku sejmy walne zwyczajne zwoływano co dwa lata na sześć tygodni, w razie potrzeby zwoływane były sejmy nadzwyczajne obradujące przez dwa tygodnie. Nie opracowywano ścisłego porządku obrad. Przyjęte było, że po nabożeństwie senatorowie spotykali się z królem, a izba poselska pod przewodnictwem najstarszego z posłów dokonywała wyboru marszałka. Po sprawdzeniu mandatów poselskich posłowie udawali się do króla i wspólnie obradowano. Powody zwołania sejmu przedstawiał kanclerz. Przyjmowano posłów z innych państw i słuchano sprawozdań finansowych. Następnie głos zabierali senatorowie, wygłaszając tak zwane wota senatorskie. Dalszy ciąg obrad toczył

${ }^{13}$ Tamże, s. 216-217. 
się oddzielnie w senacie i oddzielnie w izbie poselskiej. Posłowie przedstawiali projekty ustaw marszałkowi, ale to król decydował o tym, czy będą one przedmiotem obrad sejmu walnego. Deputaci wytypowani przez izbę poselską i senat wzajemnie informowali się o przebiegu obrad. W końcowym etapie obrad sejmu walnego głos zabierał król, zasięgając opinii senatu, odpowiadał na pytania poselskie. Wraz z ograniczaniem władzy królewskiej wzrastały kompetencje sejmu walnego. Po ogłoszeniu konstytucji Nihil novi tylko sejm walny miał prawo decydować o zawieraniu sojuszy czy warunkach traktatów pokojowych. Od pierwszych lat XVII wieku przysługiwało mu prawo wypowiadania wojny, sprawowania kontroli nad urzędnikami ministerialnymi oraz królem (za pośrednictwem tzw. senatorów-rezydentów). Sejm walny miał prawo łaski i amnestii ${ }^{14}$.

Od połowy XVII wieku sejm walny działał w coraz trudniejszych warunkach (liberum veto, liczne wojny, decentralistyczne działania magnaterii). Rosła liczba zrywanych sejmów, coraz trudniej było podjąć uchwałę. Za rządów Augusta III Sasa (1733-1763) tylko jeden sejm doszedł do skutku. Coraz częściej obrady sejmu były wykorzystywane do załatwiania interesów reprezentowanych przez państwa sąsiednie Rzeczypospolitej. Szczególnie aktywni byli dyplomaci rosyjscy i pruscy. Senat będący izbą wyższą sejmu walnego skupiał arcybiskupów, biskupów, wojewodów, kasztelanów i ministrów, którzy zasiadali w nim dożywotnio. Liczył 140 senatorów. Przewodniczącym senatu był król. Głównym zadaniem senatu było przyjmowanie projektów ustaw opracowanych w izbie poselskiej. Załatwiano również sprawy bieżące, zwłaszcza wymagające podjęcia decyzji, co było istotne w okresach, gdy sejmy były zrywane. Izba poselska to niższa izba sejmu walnego. Stanowiło ją 170 posłów (z czego 48 z Litwy). Była reprezentacją wyłącznie stanu szlacheckiego. Konstytucja Nihil novi ugruntowała pozycję szlachty, ograniczyła rolę magnaterii. W myśl jej postanowień jedynie sejm walny mógł stanowić nowe ustawy, a bez zgody sejmu walnego nie wolno było zmieniać postanowień przywilejów szlacheckich.

Liberum veto użyte zostało po raz pierwszy w 1652 roku przez posła upickiego Władysława Sicińskiego z inspiracji magnata Janusza Radziwiłła. Zasada była krytykowana dopiero pod koniec XVIII wieku, jej likwidację postulował Sejm Czteroletni, a znosiła ją Konstytucja 3 maja. Konstytucja majowa definiowała pojęcie narodu jako wspólnotę szlachty, mieszczan i chłopów, a termin obywatel odnosił się do wszystkich mieszkańców Rzeczypospolitej. Na mocy jej uchwał szlachta pozostawała stanem uprzywilejowanym, ale pozbawiona była prawa najwyższej zwierzchności wobec chłopów, których ustawa brała „pod opiekę prawa i rządu krajowego”. Konstytucja pozostawiała sejm najwyższym organem władzy w kraju, dawała mu kompetencje w zakresie ustawodawstwa, uchwalania podatków, kontrolowania rządu. Ustawa precyzowała regulamin obrad sejmowych oraz narzucała zasadę podejmowania uchwał większością głosów. Na sejmikach zapewniała głos tylko szlachcie - posesjonatom, szlachta gołota miała nie uczestniczyć w pracach sejmiku. Konstytucja utrzymała sejmiki elekcyjne (wybierające posłów na sejm) oraz sejmiki relacyjne, które miały możliwość pozbawić posła mandatu. Połączono sejmiki deputackie z gospodarczymi. Senat miał prawo zawiesić uchwałę sejmową, jednak w przypadku ponownego jej uchwalenia przez izbę poselską wchodziła ona w życie bez głosowania w senacie. Król

${ }^{14}$ Encyklopedia szkolna ..., dz. cyt., s. 587-588. 
stracił rolę „trzeciego stanu sejmującego”. Otrzymał funkcję przewodniczącego Straży Praw (organ władzy wykonawczej). Obok niego w rządzie zasiadali prymas i pięciu ministrów oraz marszałek sejmu i następca tronu (bez prawa głosu). Konstytucja wprowadzała po raz pierwszy w świecie zasadę odpowiedzialności ministra za jego działalność. Sejm miał prawo pozbawić ministra urzędu przez uchwalenie wotum nieufności większością dwóch trzecich głosów sejmu i senatu. Konstytucja z 3 maja 1791 roku zawierała ordynację miejską oraz prawo o sejmikach. Wprowadzała trójpodział władzy. Regulowała prawo własności mieszczan, prawo nabywania szlachectwa, posiadania majątków ziemskich, zajmowania stanowisk oficerskich. Konstytucja znosiła wolną elekcję i zastąpiła ją władzą dziedziczną. Wprowadzono stałą armię w liczbie 100 tysięcy żołnierzy, ustanowiono podatki w stałej wysokości 10 procent dla szlachty i 20 procent dla duchowieństwa. Ustalono jednocześnie możliwość zbierania się sejmu konstytucyjnego w celu uaktualniania zapisów w konstytucji. Powołano dwuizbowy parlament, w którym izba poselska liczyła 204 posłów szlachty ziemiańskiej i 24 plenipotentów reprezentujących miasta królewskie, a izba senacka liczyła 132 członków, w jej skład wchodzili senatorowie, wojewodowie kasztelani, ministrowie oraz biskupi. Władzą wykonawczą została rada królewska, którą tworzyli król (jako przewodniczący), pięciu ministrów, prymas Polski (jako przewodniczący Komisji Edukacji Narodowej) oraz (bez prawa głosu) następca tronu, marszałek sejmu i dwóch sekretarzy ${ }^{15}$.

Konstytucja 3 maja wywołała ostrą reakcję ze strony Rosji. Postanowienia ustawy majowej nie weszły nigdy w życie. Po trzecim rozbiorze Polacy związali swoje nadzieje na niepodległość z Francją. Konstytucja Księstwa Warszawskiego nadana przez Napoleona Bonaparte 22 lipca 1807 roku obalała nierówności społeczne, znosiła feudalne przywileje stanowe, zapewniała chłopom wolność osobistą, niestety bez prawa do własności ziemi. Nie zwalniała ich też z obowiązków świadczenia pańszczyzny. Wprowadzała zasadę równości wobec prawa (art. 4). Konstytucja likwidowała odrębne sądy i ujednolicała system sądownictwa dla wszystkich obywateli Księstwa Warszawskiego. Przyznawała prawa wyborcze części mieszczan, jednak przy wyborach do sejmu zachowywała uprzywilejowaną pozycję szlachty (art. 35). Wprowadzała świeckie prawo małżeńskie, rozwody i śluby cywilne. Zasady ustrojowe były wzorowane na porządku politycznym we Francji. Królowi pozostawiono prawo inicjatywy ustawodawczej, zatwierdzanie ustaw, możliwość wydawania dekretów oraz stosowania prawa łaski. Sejm pozostawał dwuizbowy, z prawem obradowania co dwa lata (nie dłużej niż 15 dni) w Warszawie. Projekty ustaw miały być głosowane tajnie i zatwierdzane większością głosów, a następnie kierowane do senatu (art. 22). Konstytucja pozostawiała sejmiki, zgromadzenia szlachty powiatu (art. 50) oraz zgromadzenia gminne wszystkich mieszkańców gminy (art. 51) ${ }^{16}$.

Po klęsce Napoleona I ziemie Księstwa Warszawskiego zostały na nowo podzielone między trzech zaborców, a zasadniczą ich część zagarnęła Rosja. Konstytucja Królestwa Polskiego nadana przez cara Aleksandra I w 1815 roku czyniła z Królestwa monarchię konstytucyjną połączoną z Cesarstwem Rosyjskim unią personalną. Była konstytucją liberalną, nadającą obywatelom polskim szerokie uprawnienia, między innymi wolność wyznania, nietykalność osobistą, swobodę druku, gwarancję używania języka polskiego. Król mianował

\footnotetext{
${ }^{15}$ H. Samsonowicz, dz. cyt., s. 263-264.

${ }^{16}$ Encyklopedia szkolna..., dz. cyt., s. 263-265.
} 
marszałków sejmików i zgromadzeń gminnych oraz zwoływał zgromadzenia wyborcze. Zwoływał, odraczał i rozwiązywał sejmy zwyczajne i nadzwyczajne. Zachował prawo powoływania senatorów i wyższych urzędników, dysponował inicjatywą ustawodawczą, miał prawo sankcji ustaw sejmowych. Sejm pozostawał w składzie trzech stanów sejmujących: króla, senatu i izby poselskiej, zachowując pełnię władzy prawodawczej. Posłów wybierano na sześć lat, zmieniając co dwa lata jedną trzecią składu izby. Prawo wyborcze przyznano jedynie szlachcie, która w 77 powiatach wybierała po jednym pośle, natomiast w 51 okręgach gminnych wyborcy nienależący do stanu szlacheckiego wybierali jednego deputowanego. Czynne prawo wyborcze przysługiwało mężczyznom po 21. roku życia, mającym prawa obywatelskie. Bierne prawo wyborcze posiadały osoby o określonym cenzusie wykształcenia i cenzusie majątkowym. Praw wyborczych nie posiadali wojskowi pozostający w służbie czynnej. Izba poselska podejmowała decyzje w zakresie sądownictwa, administracji i spraw cywilnych. Decydowała o sprawach podatkowych, zaciągu do wojska i systemie monetarnym w zakresie zleconym przez króla. Sprawowała kontrolę nad rządem i miała prawo składania petycji ${ }^{17}$.

Na skutek zaborów prawo na ziemiach polskich dostosowano do praw zaborców. W Królestwie Kongresowym funkcjonowanie samorządu terytorialnego było w dużym zakresie ograniczone. Nieco inaczej było w zaborze pruskim, gdzie wprowadzono podział administracyjny trójstopniowy. Najlepiej sytuacja wyglądała na obszarze zaboru austriackiego, na terenie którego bardzo mocno wykształcił się samorząd w miastach, a po 1867 roku wprowadzono szerokie swobody obywatelskie i narodowe. O pełnym zakresie działania samorządu terytorialnego w Polsce możemy mówić od momentu odzyskania niepodległości w 1918 roku i zjednoczenia ziem trzech zaborów, różniących się kulturowo, społecznie, a przede wszystkim gospodarczo. Konstytucja Rzeczypospolitej Polskiej z 17 marca 1921 roku (art. 65) wprowadzała podział państwa na województwa, powiaty, gminy miejskie i wiejskie będące równocześnie jednostkami samorządu terytorialnego. Konstytucja głosiła oparcie ustroju państwa ,na zasadzie szerokiego samorządu” terytorialnego i zawodowego (art. 3 i 68) oraz decentralizację administracji państwowej, a wzmocnienie czynnika obywatelskiego powoływanego w drodze wyborów (art. 66). Wyjątkiem był tu Śląsk, którego jednoizbowy Sejm Śląski na mocy Statutu Organicznego z dnia 15 lipca 1920 roku zachował autonomię i zyskał kompetencje ustawodawcze (bez kompetencji związanych z wojskiem oraz polityką zagraniczną) $)^{18}$.

Po przewrocie majowym (1926) ustrój Polski ulegał procesowi centralizacji. W 1933 roku tzw. ustawa scaleniowa ${ }^{19}$ i wprowadzona w 1935 roku konstytucja kwietniowa ${ }^{20}$ doprowadziły do ujednolicenia struktur samorządu terytorialnego na terenie całego kraju, przy jednoczesnym wzmocnieniu roli urzędów administracji ogólnej, czyli wojewodów i starostów, a ograniczeniu zakresu bezpośredniego oddziaływania społeczeństwa na działalność

17 Tamże, s. 251-252.

18 M. Adamczyk, S. Pastuszka, Konstytucje polskie w rozwoju dziejowym 1791-1982, WSiP, Warszawa 1985, s. 234.

19 Ustawa z dnia 23 marca 1933 r. o częściowej zmianie ustroju samorządu terytorialnego, Dz.U. 1933, nr 35, poz. 294.

${ }^{20}$ Ustawa Konstytucyjna z dnia 23 kwietnia 1935 r., Dz.U. 1935, nr 30, poz. 227. 
jednostek samorządu terytorialnego ${ }^{21}$. Konstytucja kwietniowa potwierdziła zapisy dotyczące trójszczeblowego podziału władzy w województwach, powiatach i gminach. W tym okresie w Polsce istniały 264 powiaty (w tym 23 grodzkie), 611 gmin miejskich, 3195 gmin wiejskich oraz 40 tysięcy gromad, które działały jako jednostki pomocnicze.

Funkcjonowanie tych struktur zostało przerwane w 1939 roku przez wojnę. W czasie działań wojennych starano się zachować trójstopniowy podział władzy. Polskie Państwo Podziemne stworzyło instytucje państwowe na wszystkich trzech szczeblach (gminy, powiaty, województwa), które były przygotowane do przejęcia władzy w momencie uzyskania niepodległości. Niestety rzeczywistość powojenna była nieco inna od zakładanej. Władze stalinowskie nie pozwoliły na odbudowę struktur. Po wyzwoleniu spod okupacji niemieckiej w 1944 roku deklaracje dotyczące modelu władzy państwowej i samorządu terytorialnego zawarte zostały w przepisach dekretu PKWN z dnia 21 sierpnia 1944 roku o trybie powoływania władz administracji ogólnej I i II instancji, które reaktywowały urząd wojewody i starosty w roli organów administracji rządowej. Natomiast dekret PKWN z 23 listopada 1944 roku o organizacji i zakresie działania samorządu terytorialnego przywracał instytucje tego samorządu w oparciu o ustawę samorządową z 1933 roku. Ustawa z dnia 11 września 1944 roku o organizacji i zakresie działania rad narodowych uzupełniła model administracji terenowej o system rad narodowych. Sfałszowane wybory 1947 roku dały nowej władzy możliwość wprowadzenia na wzór sowiecki wojewódzkich, powiatowych i gminnych rad narodowych, w których stanowiska były obsadzane przez ludzi służących nowej władzy i przez nią wyznaczanych. Ustawa $z$ dnia 20 marca 1950 roku o terenowych organach jednolitej władzy państwowej22 ${ }^{22}$ prowadzała rozwiązania zaczerpnięte z ustroju Związku Radzieckiego. Zlikwidowano urzędy wojewodów i starostów, ograniczono zasady samorządności, a uprawnienia zniesionych organów przejęły rady narodowe (art. 37).

Do 1950 roku w Polsce dokonano zmian w podziale administracyjnym i z dotychczasowych 14 województw utworzono 17 (dodatkowo Warszawa i Łódź były na prawach województwa). Zostało to zmienione w 1957 roku poprzez wyodrębnienie trzech kolejnych miast - Krakowa, Wrocławia i Poznania. W 1975 roku zmieniono dotychczasowy podział, w wyniku czego powstało 49 województw, zlikwidowano jednocześnie powiaty (podział ten obowiązywał do 1989 roku). Reformy samorządu terytorialnego w Polsce przeprowadzane w latach siedemdziesiątych i osiemdziesiątych XX wieku opierały się na wzorach z okresu II Rzeczypospolitej. Po okresie pełnej kontroli administracji państwowej nad wszystkimi dziedzinami życia społecznego i wszechwładzy PZPR zaczęto realizować postulaty odbudowy autentycznego samorządu terytorialnego opartego na wspólnocie ludzi wolnych $^{23}$. Środowiska opozycyjne lansowały koncepcje współdziałania małych i samodzielnych grup społecznych w celu realizowania swoich interesów. Powstanie w 1980 roku Niezależnego Samorządnego Związku Zawodowego „Solidarność” zapoczątkowało budowę społeczeństwa obywatelskiego. Postulowana przez związek reforma samorządowa miała

${ }^{21}$ M. Sidor, Samorząd terytorialny myśli politycznej II Rzeczypospolitej Polskiej, Wydawnictwo Adam Marszałek, Toruń 2010.

${ }^{22}$ Ustawa z dnia 20 marca 1950 r. o terenowych organach jednolitej władzy państwowej, Dz.U. 1950, nr 14, poz. 130.

${ }_{23}$ A. Michnik, Szanse polskiej demokracji. Artykuły i eseje, „Aneks”, Londyn 1984, s. 86-87. 
być programem przebudowy moralnej społeczeństwa ${ }^{24}$. Przyjęty 2 września 1981 roku dokument Podstawowe założenia reformy samorzadu terytorialnego w Polsce podkreślał, że podstawą samorządu terytorialnego jest społeczność lokalna, czyli gmina miejska lub wiejska rozumiana jako jednostka i korporacja terytorialna. Kryterium tworzenia tych jednostek miał stanowić interes lokalny, istnienie specyficznych potrzeb, które zaspokajane są przez wspólnotę w sposób samodzielny ${ }^{25}$.

Samorząd odzyskał swoje miejsce dopiero po odzyskaniu suwerenności w 1989 roku i pierwszych po wojnie wolnych wyborach. Przekształcenia ustrojowe pozwoliły odbudować samorząd terytorialny, czego zwieńczeniem były pierwsze wolne wybory do samorządów przeprowadzone w dniu 27 maja 1990 roku. Wybory samorządowe z maja 1990 roku to pierwsze wolne wybory od lat trzydziestych XX wieku. Trzeba wspomnieć, że Sejm RP w czerwcu 2000 roku ustanowił dzień 27 maja Dniem Samorządu Terytorialnego dla upamiętnienia wyborów z 1990 roku. Ustawa o samorządzie z 8 marca 1990 roku $^{26}$ miała zasadnicze znaczenie do przywrócenia dualizmu administracyjnego w kraju. Nastąpił podział organów dotychczasowej jednolitej władzy państwowej na organy terenowej administracji rządowej oraz organy samorządu terytorialnego. Ustawa ustalała wzajemne relacje między władzą ustawodawczą i wykonawczą Rzeczypospolitej Polskiej oraz zawierała zapisy o samorządzie terytorialnym ${ }^{27}$, zmieniając podział z dotychczasowego dwuszczeblowego (na szczeblu województw i gmin) na trójszczeblowy. Zapisy ustawy wniosły poza uzyskaniem podmiotowości prawnej znaczną niezależność ekonomiczną jednostek samorządowych. Ustawa wskazywała podział zadań oraz kompetencji pomiędzy samorządem a administracją rządową. Artykuł 1 ustawy o samorządzie terytorialnym znalazł odzwierciedlenie w Małej Konstytucji ${ }^{28}$ (art. 70 ust. 2), potwierdzając przepis, że jednostki samorządu terytorialnego posiadają osobowość prawną jako usankcjonowane prawem wspólnoty mieszkańców określonego terytorium. Mała Konstytucja z dnia 17 października 1992 roku określa ideę samorządu terytorialnego ,samorząd terytorialny jest podstawową funkcją organizacji lokalnego życia publicznego, a jednostki samorządu terytorialnego mają osobowość prawną i wykonują zadania publiczne na własną odpowiedzialność i w imieniu własnym w celu zaspokojenia potrzeb mieszkańców (art. 71 i art. 72). Konstytucja z dnia 2 kwietnia 1997 roku zawiera zapis, że ogół mieszkańców jednostek terytorialnych z mocy prawa stanowi wspólnotę samorządową ${ }^{29}$.

Samorząd terytorialny nie jest strukturą statyczną, znajduje się w ciągłym rozwoju. W Polsce w ostatnich latach nastąpiło wyraźne przesunięcie realizacji zadań z zakresu interesu publicznego ze szczebla rządowego na szczebel samorządowy, gdzie podstawową rolę odgrywają od 1990 roku gminy, a od 1999 roku kolejne szczeble samorządu: powiaty

${ }^{24}$ I Krajowy Zjazd Delegatów NSZZ „Solidarność”, Uchwała programowa z Aneksem, Biuro Informacji Prasowej Komisji Krajowej NSZZ „Solidarność”, Gdańsk 1981.

${ }^{25}$ K. Mieczkowska-Czerniak, K. Radzik-Maruszak (red.), 20 lat samorzadu terytorialnego $w$ Polsce: sukcesy, porażki, perspektywy, Wydawnictwo Uniwersytetu Marii Curie-Skłodowskiej, Lublin 2012, s. 22.

${ }^{26}$ Ustawa z dnia 8 marca 1990 r. o samorządzie terytorialnym, Dz.U. 1990, nr 16, poz. 95.

27 Tamże.

${ }^{28}$ Ustawa Konstytucyjna z dnia 17 października 1992 r. o wzajemnych stosunkach między władzą ustawodawczą i wykonawczą Rzeczypospolitej Polskiej oraz o samorządzie terytorialnym, Dz.U. 2002, nr 84, poz. 426 z późn. zm.

${ }^{29}$ Konstytucja Rzeczypospolitej Polskiej z dnia 2 kwietnia 1997 r., Dz.U. 1997, nr 78, poz. 489. 
i województwa rządowo-samorządowe. Zadania publiczne lokuje się możliwie jak najbliżej obywatela. Procesy demokratyzacji w Polsce i tworzenie gospodarki rynkowej to proces wprowadzania koncepcji społeczeństwa samorządnego. Społeczeństwo budowane oddolnie to społeczeństwo demokratyczne posiadające prawa i obowiązki przynależne wszystkim obywatelom wspólnoty. Biorąc udział w życiu lokalnej społeczności poprzez uczestnictwo w wyborach władz każdego szczebla obywatel może kształtować społeczno-gospodarcze otoczenie i przez to wykorzystywać swoje prawa nadane mu przez państwo demokratyczne. Radni wybrani przez mieszkańców mają wpływ na zatrudnienie urzędników, którzy działają na rzecz lokalnej społeczności. Regulacje prawne wprowadzone od 1990 roku pozwoliły na ukształtowanie trzyszczeblowej struktury samorządowej, tj. samorządu terytorialnego na szczeblu gminy, powiatu i województwa. Ustawa z 1990 roku regulowała zasady wprowadzenia samorządu gminnego $0^{30}$.

Europejska Karta Samorządu Terytorialnego, którą Polska ratyfikowała w kwietniu 1993 roku definiuje pojęcie samorządu lokalnego, wprowadza zasadę subsydiarności i reguluje istotę działalności organów władzy, będących najbliżej obywatela. Tylko zadania przekraczające możliwości gmin powinny zostać $\mathrm{w}$ gestii wyższych organów administracji publicznej. Kolejne lata to kolejne projekty i próby zmian liczby województw i powiatów. Prace nad zmianami w prawie dotyczącym samorządów zostały w 1993 roku zablokowane przez koalicję SLD-PSL. Późniejszy program pilotażowy wprowadzony 1 stycznia 1994 roku skierowany do władz największych polskich miast pozwalał przećwiczyć możliwość przejęcia dodatkowych zadań przez powiaty. Zapisy rozdziału VII Konstytucji z 1997 roku $^{31}$ pozwoliły wprowadzić zasady samodzielności, subsydiarności i domniemania kompetencji, a co za tym idzie, decentralizację władzy. Kolejnym krokiem przywracającym samorządność na szczeblach powiatowych i regionalnych była reforma administracji, która weszła w życie od 1 stycznia 1999 roku. Nastąpiła kolejna zmiana liczby województw, z dotychczasowych 49 utworzono 16, wydzielając jednocześnie ponad 370 powiatów oraz ponad 2450 gmin. Większość dotychczasowych miast wojewódzkich weszło do grupy miast na prawach powiatu ${ }^{32}$. Zmiany te wniosły jednocześnie zwiększenie uprawnień marszałka województwa i samorządu wojewódzkiego kosztem uprawnień wojewody. Wiązało się to z przekazaniem tym pierwszym udziału w podatku dochodowym od osób prywatnych, subwencji i dotacji. W 2002 roku wprowadzono ustawą bezpośrednie wybory wójtów, burmistrzów oraz prezydentów miast. W wyniku decentralizacji władzy samorząd wykonuje wiele zadań z zakresu umożliwia sprawniejsze jego zarządzanie, pozwala bowiem dotrzeć do każdego regionu wielokrotnie o różnej specyfice od pozostałych. Znaczącym bowiem kryterium w zarządzaniu jest jej jednolitość geograficzna, społeczna, gospodarcza, historyczna. Należy bowiem pamiętać, że samorząd to nie tylko urzędy, radni i urzędnicy w nich zasiadający, ale to wszyscy mieszkańcy gmin, wszyscy mieszkańcy powiatów oraz wszyscy mieszkańcy województwa.

\footnotetext{
${ }^{30}$ Ustawa z dnia 8 marca 1990 r. o samorządzie gminnym, Dz.U. 1990, nr 16, poz. 95.

${ }^{31}$ Konstytucja Rzeczypospolitej Polskiej z dnia 2 kwietnia 1997 r., dz. cyt.

32 Reforma administracyjna, Monitor Samorządowy, http://www.regioset.pl/monitor.php?lg=0\&ar$\mathrm{t}=6 \&$ unit=4 [dostęp: 31.10 .2018 ].
} 
Największą jednostką samorządu terytorialnego jest województwo. W Polsce mamy 16 województw, z czego największym pod względem obszaru jest mazowieckie liczące ponad $35558 \mathrm{~km}^{2}$, najmniejszym zaś opolskie liczące nieco ponad $9411 \mathrm{~km}^{2}$. Najwięcej mieszkańców liczy województwo mazowieckie - ponad 5188 tysięcy, najmniej lubuskie około 1008 tysięcy ${ }^{33}$.

Kompetencje samorządu wojewódzkiego to m.in.:

- posiadanie osobowości prawnej,

- tworzenie aktów prawnych obowiązujących na obszarze województwa,

- $\quad$ wykonywanie zadań publicznych w imieniu własnym i na własną odpowiedzialność,

- $\quad$ prowadzenie własnej gospodarki finansowej,

- rozwijanie i pielęgnowanie tożsamości lokalnej,

- $\quad$ troska o rozwój świadomości obywatelskiej i pielęgnowanie polskości,

- odpowiedzialność za gospodarkę przestrzenną,

- pobudzanie aktywności gospodarczej,

- pozyskiwanie funduszy,

- wspieranie rozwoju nauki,

- $\quad$ wspieranie działań na rzecz innowacji i postępu technologicznego,

- prowadzenie działań mających na celu ochronę dziedzictwa kulturowego,

- promowanie walorów województwa,

- wspieranie rozwoju kultury,

- dbanie o ochronę środowiska,

- $\quad$ prowadzenie pomocy społecznej i polityki prorodzinnej,

- aktywizacja rynku pracy.

Sejmik województwa jest organem o charakterze stanowiącym i kontrolnym zgodnie z zapisami ustawy z dnia 5 czerwca 1998 r. o samorządzie województwa. Sejmik województwa działa w obszarze ustalania strategii rozwoju województwa, jego budżetu, aktów prawa miejscowego. Jako organ kontrolny koncentruje się na sprawach związanych z wykonaniem budżetu przez zarząd województwa ${ }^{34}$.

Starostwo powiatowe to jednostka pomocnicza zarządu składająca się z wydziałów, które odpowiadają za konkretne rodzaje spraw. Najczęściej funkcjonują wydziały: finansowy, rolnictwa, kultury i sportu, geodezji, oświaty, gospodarki nieruchomościami, zarządzania kryzysowego. Samorząd powiatowy wypełnia określone ustawowo zadania publiczne ponadgminne. Pamiętać trzeba, że wysyłając wnioski czy pisma, zwracamy się do zarządu powiatu, a nie do starostwa powiatowego. W miastach na prawach powiatu nie ma starostwa powiatowego, a jego zadania wykonuje urząd miasta (rada miasta i prezydent miasta). Wykonują oni zadania według kompetencji odpowiednio rady gminy i rady powiatu oraz wójta (burmistrza) i starosty. Rada nie może wybierać organu wykonawczego i nie może go odwołać. Powiatowa administracja zespolona to trzy rodzaje urzędów składających się ze starostwa powiatowego, powiatowego urzędu pracy oraz jednostek organizacyjnych

\footnotetext{
33 Polska. Podziat terytorialny, Interia. Encyklopedia, https://encyklopedia.interia.pl/geografia-nauki-pokrewne/krainy-geograficzne/news-polska-podzial-terytorialny,nId,2025206 [dostęp: 31.10.2018].

${ }^{34}$ Ustawa z dnia 5 czerwca 1998 r. o samorządzie województwa, Dz.U. 1998, nr 91, poz. 576.
} 
stanowiących aparat pomocniczy kierowników powiatowych służb, inspekcji i straży. Do głównych obszarów zadań powiatu należą:

- edukacja publiczna,

- polityka prorodzinna,

- $\quad$ kultura fizyczna i turystyka,

- transport publiczny i zbiorowy,

- geodezja, kartografia i kataster,

- ochrona środowiska i przyrody,

- ochrona przeciwpowodziowa i przeciwpożarowa,

- aktywizacja lokalnego rynku pracy,

- $\quad$ współpraca z organizacjami pozarządowymi,

- promocja powiatu.

Rada gminy jest organem stanowiącym i kontrolnym. Jej kadencja trwa 4 lata, a członków rady wybierają pełnoletni mieszkańcy gminy. Rada gminy kontroluje działalność wójta, gminnych jednostek organizacyjnych oraz jednostek pomocniczych. Na jej czele stoi przewodniczący Rady Gminy. Skład rady gminy zależy od liczby mieszkańców: w gminach do 20 tysięcy mieszkańców - 15 radnych, do 50 tysięcy - 21 radnych, do 100 tysięcy mieszkańców - 23 radnych, do 200 tysięcy mieszkańców - 25 radnych, natomiast po 3 radnych na kolejne rozpoczęte 100 tysięcy mieszkańców (nie więcej niż 45 radnych). Do zadań rady gminy należy podejmowanie uchwał dotyczących uchwalania budżetu, wysokości wynagrodzenia wójta, planów zagospodarowania przestrzennego. Organami o charakterze wykonawczym są:

- $\quad$ wójt, stojący na czele zarządu gminy wiejskiej,

- $\quad$ burmistrz, stojący na czele zarządu gminy w mieście liczącym do 100 tysięcy mieszkańców,

- $\quad$ prezydent, stojący na czele zarządu gminy w mieście powyżej 100 tysięcy mieszkańców.

Wszyscy trzej powoływani są na czteroletnią kadencję. Wójt wykonuje zadania przy pomocy urzędu gminy i do jego zadań należy: wykonywanie budżetu, zatrudnianie i zwalnianie kierowników gminnych jednostek organizacyjnych, gospodarowanie mieniem komunalnym, przygotowanie projektów uchwał rady gminy i określanie sposobu ich realizowania. W funkcjonowaniu gminy pomagają jednostki pomocnicze. Sołectwo to jeden z tych organów. Sołectwem kieruje sołtys, który jest organem wykonawczym. Sołectwo może obejmować jedną lub więcej miejscowości, może istnieć również kilka sołectw w jednej miejscowości. Organem uchwałodawczym w sołectwie jest zebranie wiejskie. Gmina wykonuje wszystkie działania na własną odpowiedzialność, realizuje zlecone przez organy administracji rządowej zadania. Jej podstawowym obowiązkiem jest zaspokajanie potrzeb mieszkańców związanych z ładem przestrzennym, drogami, gospodarką nieruchomościami, ochroną środowiska, edukacją, pomocą społeczną, transportem zbiorowym, porządkiem publicznym, cmentarzami, wodociągami i kanalizacją, bibliotekami gminnymi ${ }^{35}$.

Znaczącą kwestią działań na rzecz rozwoju lokalnego jest partycypacja społeczna, która jest podstawą społeczeństwa obywatelskiego. Udział jednostek w działaniach zbiorowych,

\footnotetext{
${ }^{35}$ Ustawa z dnia 8 marca 1990 r. o samorządzie gminnym, dz. cyt.
} 
podejmowanych w społecznościach, do których przynależą, polega na udziale w wyborach, referendach, konsultacjach społecznych, akcjach bezpośrednich czy postępowaniu administracyjnym. Partycypacja społeczna daje możliwość aktywnej obecności w kształtowaniu i funkcjonowaniu grup obywatelskich, organizacji pozarządowych. Jest to zgodne z definicją samorządu lokalnego zawartą w Europejskiej Karcie Samorządu Lokalnego ${ }^{36}$ (uchwalona 15 października 1985 roku) potwierdzającej, że samorząd to wspólnoty lokalne upoważnione do regulowania i zarządzania na rzecz jej ludności w ramach prawa poprzez rady lub zgromadzenia członków tego samorządu wybranych w głosowaniu powszechnym, bezpośrednim, tajnym, wolnym i równym. Sprawy samorządności ważne są w każdym społeczeństwie, potwierdzeniem tego faktu jest uchwalenie Światowej Deklaracji Samorządu Lokalnego na 27. Światowym Kongresie Międzynarodowym Związku Władz Lokalnych, który miał miejsce w dniach 22-26 września 1985 roku w Rio de Janeiro. Dokument ten definiuje samorząd lokalny jako ,prawo i powinność władz lokalnych do lokalnego regulowania i zarządzania sprawami publicznymi dla dobra społeczności lokalnej” (art. 2 ust. 1) ) $^{37}$ Mimo że w różnych państwach funkcjonują różne modele samorządu terytorialnego i są jedną z podstawowych instytucji ustrojowo-prawnych, to w każdym istotą samorządności jest powyższe sformułowanie prawne.

\section{Bibliografia}

Adamczyk M., Pastuszka S., Konstytucje polskie w rozwoju dziejowym 1791-1982, WSiP, Warszawa 1985.

Brückner A., Słownik etymologiczny języka polskiego, Wiedza Powszechna, Warszawa 1985.

Bukowski Z., Kamosiński S., Samorzad terytorialny w Polsce. Wybrane aspekty funkcjonowania, Wydawnictwo Uniwersytetu Kazimierza Wielkiego, Bydgoszcz 2014.

Dolnicki B., Samorząd terytorialny, zagadnienia ustrojowe, Zakamycze, Kraków 1999.

Dziurak A., Gałęzowski M., Kamiński Ł., Musiał F., Od niepodległości do niepodległości. Historia Polski 1918-1989, IPN, Warszawa 2014.

Encyklopedia szkolna. Historia, WSiP, Warszawa 1995.

Hebda J., Z sottysem i wójtem przez wieki. Opowieść o dziejach urzędu sottysa i wójta w Polsce, Muzeum Historii Polskiego Ruchu Ludowego, Tarnów-Warszawa 2016.

I Krajowy Zjazd Delegatów NSZZ „Solidarność”. Uchwała programowa z Aneksem, Biuro Informacji Prasowej Komisji Krajowej NSZZ „Solidarność”, Gdańsk 1981.

Izdebski H., Kulesza M., Administracja publiczna: zagadnienia ogólne, Liber, Warszawa 2004.

Konstytucja Nihil novi (1505 r.), https://historia.org.pl/2009/10/27/konstytucja-nihil-novi-1505-r/ [dostęp: 31.10.2018].

Michnik A., Szanse polskiej demokracji. Artykuty i eseje, „Aneks”, Londyn 1984.

\footnotetext{
${ }^{36}$ Europejska Karta Samorządu Lokalnego, Dz.U. 1994, nr 124, poz. 607.

${ }^{37}$ Polski tekst Światowej Deklaracji Samorządu Lokalnego został opublikowany we wkładce do dwutygodnika „Gospodarka - Administracja Państwowa” z października 1988 r.
} 
Mieczkowska-Czerniak K., Radzik-Maruszak K. (red.), 20 lat samorzadu terytorialnego w Polsce: sukcesy, porażki, perspektywy, Wydawnictwo Uniwersytetu Marii Curie-Skłodowskiej, Lublin 2012.

Piasecki A., Samorzad terytorialny i wspólnoty lokalne, PWN, Warszawa 2009.

Polska. Podziat terytorialny, Interia. Encyklopedia, https://encyklopedia.interia.pl/geografia -nauki-pokrewne/krainy-geograficzne/news-polska-podzial-terytorialny,nId,2025206 [dostęp: 31.10.2018].

Reforma administracyjna, Monitor Samorządowy, http://www.regioset.pl/monitor.php?lg=0\&ar-

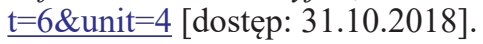

Roszkowski W., Historia Polski 1914-1990, PWN, Warszawa 1992.

Samsonowicz H., Historia Polski do roku 1795, WSiP, Warszawa 1985.

Sidor M., Samorzad terytorialny myśli politycznej II Rzeczypospolitej Polskiej, Wydawnictwo Adam Marszałek, Toruń 2010.

Tazbir J. (red.), Polska na przestrzeni wieków, PWN, Warszawa 1995.

\section{Akty prawne}

Europejska Karta Samorządu Lokalnego, Dz.U. 1994, nr 124, poz. 607.

Konstytucja Rzeczypospolitej Polskiej z dnia 2 kwietnia 1997 r., Dz.U. 1997, nr 78, poz. 489.

Ustawa z dnia 23 marca 1933 r. o częściowej zmianie ustroju samorządu terytorialnego, Dz.U. 1933, nr 35, poz. 294.

Ustawa z dnia 20 marca 1950 r. o terenowych organach jednolitej władzy państwowej, Dz.U. 1950, nr 14, poz. 130 .

Ustawa z dnia 8 marca 1990 r. o samorządzie gminnym, Dz.U. 1990, nr 16, poz. 95.

Ustawa z dnia 8 marca 1990 r. o samorządzie terytorialnym, Dz.U. 1990, nr 16, poz. 95.

Ustawa z dnia 8 marca 1990 r. o samorządzie terytorialnym. Metryka, Infor.pl, https://www. infor.pl/akt-prawny/DZU.1990.016.0000095, metryka, ustawa-o-samorzadzie-terytorialnym. html [dostęp: 8.02.2019].

Ustawa z dnia 5 czerwca 1998 r. o samorządzie województwa, Dz.U. 1998, nr 91, poz. 576.

Ustawa Konstytucyjna z dnia 23 kwietnia 1935 r., Dz.U. 1935, nr 30, poz. 227.

Ustawa Konstytucyjna z dnia 17 października 1992 r. o wzajemnych stosunkach między władzą ustawodawczą i wykonawczą Rzeczypospolitej Polskiej oraz o samorządzie terytorialnym, Dz.U. 2002, nr 84, poz. 426 z późn. zm.

\section{Streszczenie}

\section{Samorząd terytorialny w Polsce - zarys historyczny}

Początki samorządu terytorialnego na naszych ziemiach wiążą się z powstaniem państwa polskiego. Samorząd terytorialny przez minione stulecia ulegał zmianom, których podłożem były losy państwa i społeczeństwa. Samorządność w postaci starosłowiańskich wieców przekształciła się w XV wieku w szlacheckie sejmiki decydujące zarówno 
o sprawach lokalnych, jak i państwowych. Lata zaborów wpłynęły na ograniczenie kompetencji polskich instytucji samorządowych. Dopiero okres po odzyskaniu niepodległości sprzyjał budowaniu rodzimych struktur samorządu terytorialnego. Czas okupacji zmusił Polaków do tworzenia podziemnych struktur samorządowych. Z kolei lata powojenne narzuciły rozwiązania ustrojowe zaczerpnięte z wzorca sowieckiego. Przemiany ustrojowe 1989 roku otworzyły drogę do stworzenia społeczeństwa obywatelskiego.

Słowa kluczowe: samorząd terytorialny, wiec, sejmiki, sołtys, wójt, burmistrz, gmina, powiat, województwo, ustawa, konstytucja

\section{Summary \\ Territorial local government in Poland - an historical overview}

The beginnings of territorial local government in our lands are connected with the creation of the Polish state. Territorial local government has changed over the past centuries, based on the fate of the state and society. Local government in the form of Old Slavic rallies evolved in the fifteenth century into dietines held by gentry deciding both on local and state matters. Years of partitions had an impact on limiting the competences of Polish government institutions. The period after regaining independence was conducive to building native territorial local government structures. The time of occupation forced Poles to create underground local government structures. The post-war years imposed constitutional solutions taken from the Soviet pattern. The political changes of 1989 opened the way to create a civil society.

Keywords: territorial local government, rally, dietine, village administrator, mayor, mayor (provost), commune, county, voivodship, statute, constitution 


\section{Ekonomia społeczna w samorządzie terytorialnym}

Pierwsze zapisy świadczące o wyodrębnieniu się ekonomii jako nauki można było znaleźć ponad 250 lat temu ${ }^{1}$. Na przestrzeni czasu dziedzina ta ewoluowała, rozszerzała swoje zainteresowania, obierała nowe cele i ukierunkowana została na nowe zagadnienia. W ostatnich latach w celu likwidacji bezrobocia, wykluczenia społecznego, ubóstwa, zróżnicowania dochodów i innych negatywnych zjawisk zaczęto do ekonomii wprowadzać dwa modele: model państwa dobrobytu oraz model społecznej gospodarki rynkowej. Model społecznej gospodarki rynkowej znany jest od lat trzydziestych XX wieku. Kieruje się on zapobieganiem wykluczeniu i ochroną najsłabszych, zagwarantowaniem im świadczeń społecznych, łatwiejszego dostępu do edukacji, opieki zdrowotnej, kultury itp. Kolejny model - model państwa dobrobytu - ma swój początek w latach powojennych i szczególnie rozpowszechnił się w państwach skandynawskich. Ma on za zadanie chronić obywateli przed możliwością utraty zatrudnienia, zdrowia i związanym z tym ubóstwem czy bezrobociem oraz innymi działaniami mającymi związek z funkcjonowaniem gospodarki rynkowej. Model ten jest nakierowany na poszerzanie systemu świadczeń i usług socjalnych. Trzeba jednak zwrócić uwagę, że takie założenia można wprowadzać tylko w krajach o wysokim PKB, znajdujących się na zaawansowanym poziomie rozwoju gospodarczego. Wszystkie działania powinny być skorelowane między dobrami pracodawcy i pracownika oraz z zachowaniem harmonii dla wzrostu gospodarczego i sprawiedliwego podziału dóbr ${ }^{2}$.

${ }^{1}$ J. Pach, Innowacyjność ekonomii społecznej w kontekście rozwiazywania problemów społeczno-gospodarczych, [w:] D. Murzyn, J. Pach (red.), Ekonomia społeczna, między rynkiem, państwem a obywatelem, Difin, Warszawa 2018, s. 25.

2 Tamże, s. 28, 29. 
Pojęcia ekonomia społeczna użyto po raz pierwszy we Francji na początku XIX wieku³. Można wnioskować, że powstało ono na kanwie problemów rynku i państwa oraz braku współdziałania ich między sobą, a także chęci niwelowania problemów ekonomicznych. Obecnie nie ma jednoznacznej definicji ekonomii społecznej, można spotkać ich wiele, m.in. tę mówiącą, że ekonomia społeczna to gospodarka społeczna, ekonomia solidarności. W Krajowym Programie Ekonomii Społecznej widnieje wyjaśnienie: „ekonomia społeczna to sfera aktywności obywatelskiej, która poprzez działalność ekonomiczną i działalność pożytku publicznego służy: integracji zawodowej i społecznej osób zagrożonych marginalizacją społeczną, tworzeniu miejsc pracy, świadczeniu usług społecznych użyteczności publicznej (na rzecz interesu ogólnego) oraz rozwojowi lokalnemu"4. Powinna być ona traktowana jako element i jeden z obszarów rozwoju każdej społeczności ${ }^{5}$. Jednak odnosi się ona do wielu sfer życia społecznego. Ekonomia społeczna ma służyć likwidacji niesprawiedliwości społecznej, do czego przyczynia się poszukiwanie sposobów rozwiązywania problemów społecznych, bez względu na ich pochodzenie ${ }^{6}$. Ma ona związek z dostępem do równych szans w życiu społeczno-gospodarczym oraz politycznym, obiektywnym podziałem dóbr, a także prawem, które powinno być równe dla wszystkich ${ }^{7}$. Ekonomia społeczna związana jest nierozerwalnie z rozwojem gospodarki, która ma umożliwiać coraz lepsze warunki do życia ludzi. Swoje zainteresowanie zwraca ona ku naukom, których celem jest badanie aspektów społeczeństwa ${ }^{8}$.

W ekonomii społecznej ważne miejsce zajmuje także kultura oraz przestrzeganie podstawowych wartości. Połączona jest ona z gospodarowaniem bezpieczeństwem ekonomicznym i wzmacnianiem więzów społecznych, a co za tym idzie - rozwojem socjalnym. Ekonomia społeczna wchodzi w różnego typu relacje, by osiągnąć wyznaczone cele. Nawet pobieżny przegląd polityki gospodarczej państw Unii Europejskiej pokazuje szeroki zakres wdrażania tej nowej specjalności.

Ekonomia społeczna w Hiszpanii prowadzona jest m.in. poprzez program „Santiago Social”, który jest realizowany przez władze regionu Galicji, a także miasta Santiago de Compostela. Program ten ma na celu wspomaganie osób, które mają ograniczony dostęp do rynku pracy. Ma doprowadzić do rozwoju lokalnego i posługiwania się potencjałem, który płynie od mieszkańców regionu. Galicja jest obszarem w większości rolniczym, który położony jest w północno-zachodniej części Hiszpanii (to region Hiszpanii graniczący z Portugalią

${ }^{3}$ P. Sałustowicz, Pojęcie, koncepcje i funkcje ekonomii społecznej, „Ekonomia Społeczna Teksty” 2/2007, http://www.ekonomiaspoleczna.pl/files/ekonomiaspoleczna.pl/public/Biblioteka/2007.13.pdf [dostęp: 24.05.2018].

${ }^{4}$ Uchwała nr 164 Rady Ministrów z dnia 12 sierpnia 2014 r. w sprawie przyjęcia programu pod nazwą „Krajowy Program Rozwoju Ekonomii Społecznej”, M.P. 2014, poz. 811.

5 J. Kwiatkowski, Ekonomia społeczna: moda czy remedium? Wprowadzenie do dyskusji, [w:] J. Kwiatkowski, A. Okraszewska (red.), Ekonomia społeczna: moda czy remedium?, FRDL Małopolski Instytut Samorządu Terytorialnego i Administracji w Krakowie, Kraków 2008, s. 14.

${ }_{6}$ Z. Narski, Ekonomia społeczna, Wydawnictwo Adam Marszałek, Toruń 2012, s. 14.

7 J. Sztumski, Aktualność idei sprawiedliwość społeczna w polityce społecznej, [w:] B. Balcerzak-Parandowska, A. Rączaszek (red.), Międzynarodowa polityka społeczna - aspekty porównawcze, IPSS, Warszawa 2010, s. 67.

${ }_{8}$ T. Tylec, Ekonomia społeczna - idea i kierunki rozwoju koncepcji, [w:] D. Murzyn, J. Pach (red.), Ekonomia społeczna, między rynkiem, państwem a obywatelem, Difin, Warszawa 2018, s. 15. 
i Oceanem Atlantyckim). Z racji, iż jest to teren mało uprzemysłowiony, panuje tam wysokie bezrobocie (szacuje się, że wśród osób w wieku od 16 do 29 lat bezrobocie osiąga 26,6 procent) ${ }^{9}$. Santiago de Compostela jest regionem turystycznym, celem pielgrzymek, ponieważ znajdują się tam prochy św. Jakuba, który jest patronem Hiszpanii. Obszar ten cechuje się dużymi problemami z powtórną integracją społeczną i zawodową osób pozostających bez zatrudnienia oraz reemigrantów powracających do Hiszpanii ${ }^{10}$.

Program „Santiago Social” nastawiony jest na pomoc przy rozwoju lokalnym i wykorzystaniu miejscowych zasobów oraz ma na celu wzmocnienie rynku pracy. W kontekście Galicji najbardziej brane są pod uwagę turystyka oraz rolnictwo. Duże znaczenie ma tutaj kwestia reemigrantów, którzy w ostatnich latach coraz chętniej powracają do kraju oraz osób pozostających bez pracy. Program ten ma ułatwić zapoznanie się z regułami i prawami obowiązującymi w kraju oraz ma zapewnić pomoc w wykorzystaniu ich wiedzy czy doświadczenia, a przede wszystkim zjednoczyć z pozostałą częścią społeczności.

W sprawie realizacji tego programu powołano radę programu, która działa w imieniu rządu autonomicznego Galicji. ,Składa się ona z przedstawicieli władz regionu, samorządów gmin wchodzących w skład regionu, przedstawicieli NGO, lokalnego biznesu i spółdzielczości" ${ }^{11}$. W kompetencjach rady leży: wyznaczanie strategii działania, kierunków realizacji i obserwowanie oraz ewentualne wprowadzanie zmian w programie. Wszystkie te działania mają na celu łączenie osób wraz z regionalnym rynkiem pracy.

Do realizacji programu powołane są również jednostki analityczne, doradcze, programowe oraz z bliskiego otoczenia biznesu, które znajdują się na obszarze całego regionu. Ich działania charakteryzują się wspomaganiem rozpoczynania działalności nowych przedsiębiorstw i związanymi z tą działalnością dotacjami oraz ulgami podatkowymi, przywilejami w procedurach przetargowych, udzielaniem wsparcia technicznego, administracyjnego, z zakresu reklamy, a także przedstawianiem ofert szkoleń dla bezrobotnych chcących znaleźć pracę. Osoby czerpiące zyski z tego programu są dokładnie sprawdzane pod kątem potrzeb i możliwości. Pozwala to zoptymalizować i przygotować jak najlepsze wejście na rynek pracy. Taki beneficjent uczestniczy w projektach szkoleniowo-doradczych i symulacjach tworzenia miejsc pracy. Efekt tego programu to zakładanie nowych różnorodnych firm, które odpowiadają na lokalne zapotrzebowanie. Są wśród nich takie przedsiębiorstwa, jak sklepy, kawiarnie, restauracje, a także instytucje społeczne - spółdzielnie socjalne zatrudniające również osoby niepełnosprawne ${ }^{12}$. W Hiszpanii władze regionalne posiadają duże uprawnienia, dzięki czemu w większym stopniu niż w Polsce mogą doprowadzić do sytuacji, w której współpraca biznesu, administracji publicznej oraz organizacji społecznych na zasadach społecznej solidarności może wspomóc rozwój gospodarczy i społeczny.

Ekonomia społeczna we Włoszech skupia się na zapobieganiu marginalizacji na rynku pracy. Jednakże państwa te różnią metody wykorzystywane do realizacji tych zdań. We Włoszech ekonomia społeczna jest w rękach władz lokalnych oraz regionalnych i swoimi

${ }^{9}$ R. Rivas de Roca García, Galicja, kraina rozczarowanych młodych ludzi, https://cafebabel.com/pl/ article/galicja-kraina-rozczarowanych-mlodych-ludzi-5ae00b67f723b35a145e7781/ [dostęp: 8.06.2019].

10 J. Kwiatkowski, A. Okraszewska (red.), Ekonomia społeczna: moda czy remedium?, FRDL Małopolski Instytut Samorządu Terytorialnego i Administracji w Krakowie, Kraków 2008, s. 7, 8.

${ }^{11}$ Cyt. za: J. Kwiatkowski, A. Okraszewska, dz. cyt., s. 9.

12 Tamże, s. 8, 9. 
działaniami wykracza znacznie dalej. Ekonomia społeczna w tym państwie budowana jest na zasadzie demokracji lokalnej, podkreślane są tam zasady działania wspólnotowego i solidarności społecznej opartej na regułach rynkowych. Tworzy ona tam tzw. trzeci sektor, który na świecie zapoczątkowali premier Wielkiej Brytanii T. Blair i prezydent USA B. Clinton. We Włoszech stawia się na aktywność obywateli i przedsiębiorczość, która w konsekwencji ma przynosić społeczne i ekonomiczne korzyści dla wszystkich osób zamieszkujących daną wspólnotę. Dane z 2008 roku pokazują, że już w tym czasie aż 75 procent usług społecznych znajdowało się w rękach trzeciego sektora ${ }^{13}$.

Mieszkańcy Włoch angażują się w działalność fundacji, wolontariatów, stowarzyszeń pomocy społecznej czy spółdzielni socjalnych. Wymienione instytucje są ważnym partnerem administracji publicznej. Ekonomia społeczna już od samego początku uwzględniana jest w planowaniu zadań publicznych oraz ustalaniu priorytetów i celów polityki społecznej oraz gospodarczej mającej obejmować dany region. Można zatem stwierdzić, że ekonomia społeczna jest nie tylko kreatorem, ale i realizatorem polityki społeczno-gospodarczej.

Współpraca podmiotów ekonomii na poziomie krajowym we Włoszech odbywa się dzięki Forum Trzeciego Sektora. Każdy bank działający we Włoszech zobowiązany jest do udzielania bezinteresownej pomocy finansowej lub materialnej potrzebującym w wysokości 2 procent zysków. Dzięki temu możliwe jest utworzenie Funduszu Krajowego, który realizuje za pomocą trzeciego sektora przedsięwzięcia społeczne. Forum Trzeciego Sektora współpracuje ze stowarzyszeniem ACRI, które utworzyło i finansuje chociażby Fundację Południa (Fundazione Sud). Za cel tej fundacji przyjęto chęć zmniejszania różnic między północą a południem kraju ${ }^{14}$.

Co roku we Włoszech władze regionu określają szczegółowe zasady współdziałania z podmiotami ekonomii społecznej, a także typują nowe, które mogłyby dołączyć do tego grona. Podmioty ekonomii społecznej cieszą się wieloma przywilejami, m.in. mogą wykonywać usługi publiczne z wyłączeniem niektórych procedur przetargowych. Podkreślane są też procedury długookresowej współpracy i rozwoju z wykorzystaniem zasad społecznej odpowiedzialności lokalnej i urzędników oraz wyrównywaniem szans.

W jednym z włoskich miasteczek, Terni (miasto w Umbrii), przy zakładzie karnym działa spółdzielnia socjalna, która zajmuje się produkcją i sprzedażą wyrobów cukierniczych i pieczywa. Mieszkańcy chętnie kupują wymienione produkty, co pozytywnie wpływa na proces resocjalizacji więźniów i ponowną integrację ze społeczeństwem. Taka sytuacja pokazuje, jak szeroko może być rozumiana i wykorzystywana ekonomia społeczna ${ }^{15}$.

Jak widać, ekonomia społeczna coraz częściej pojawia się w wielu dziedzinach życia człowieka; ciągle ewoluuje, wiąże się z tworzeniem wielu programów pomocy społecznej i zwalczaniem wykluczenia. Pojawia się coraz więcej programów długookresowych, które są oparte na zasadzie solidarności społecznej. W proces ten zaangażowane są nie tylko jednostki administracji publicznej, ale przede wszystkim przedsiębiorstwa, tworzone spółdzielnie oraz nawet Unia Europejska, która wspiera finansowo powstałe działania. Znaczenie

${ }_{13}$ J. Bugajski, Ekonomia społeczna - nowość nie tylko polska, http://www.sprawynauki.edu.pl/features/ the-community/1443?task=view [dostęp: 8.06.2018]

14 J. Kwiatkowski, A. Okraszewska, dz. cyt., s. 12.

15 Tamże, s. 12. 
ekonomii społecznej stale rośnie, ponieważ uznaje się, że jest ona rozwiązaniem dobrym dla wszystkich. W pewnym momencie pozwala ona na niezależność, która daje możliwość brania odpowiedzialności za swoje otoczenie, a przede wszystkim za siebie samego.

W Polsce pierwsze wzmianki o ekonomii społecznej można znaleźć już w XIX wieku. Były one związane z rozwojem stowarzyszeń, fundacji czy spółdzielni. Największy wzrost zainteresowania tym pojęciem przypada na okres po 1989 roku, kiedy miała miejsce przemiana ustrojowa. Funkcję pracodawcy od państwa przejęły prywatne przedsiębiorstwa, które w coraz mniejszym stopniu dbały o ubezpieczenia społeczne swoich pracowników. Obecne polskie programy z dziedziny ekonomii społecznej to chociażby: Krajowy Program Rozwoju Ekonomii Społecznej, Długookresowa Strategia Rozwoju Kraju - Polska 2030. Trzecia fala nowoczesności, Strategia Rozwoju Kraju 2020 i inne ${ }^{16}$.

Ekonomia społeczna może przyczynić się do rozwoju gmin i powiatów. Postęp tej dziedziny na poziomie lokalnym jest możliwy dzięki ciągłemu podnoszeniu kwalifikacji osób pracujących w samorządzie i jego agendach. Niezbędne przy wprowadzaniu ekonomii społecznej jest budowanie dialogu i zaufania na zasadzie partnerstwa. Pomaga ona także w aktywizacji zawodowej mieszkańców danego regionu, do czego mogą się przysłużyć szkolenia osób bezrobotnych. Jest to powiązane z działalnością przedsiębiorczości społecznej i rozwojem społeczeństwa obywatelskiego.

W zakresie rozwoju gmin i powiatów oraz rozwiązywania ich problemów w książce A. Sobolewskiego wskazane jest, iż ekonomia społeczna może pomóc: ,,aktywizacji zawodowej i społecznej osób niepełnosprawnych; aktywizacji zawodowej osób wykluczonych; przedłużeniu aktywności zawodowej; tworzeniu dodatkowych możliwości zarobkowych; integracji społecznej; pozyskiwaniu środków zewnętrznych; przeciwdziałaniu ucieczce młodych; aktywizacji starszych mieszkańców (zawodowej i społecznej); przeciwdziałaniu alienacji i anonimowości nowych osiedli; oddłużaniu mieszkań komunalnych i spółdzielczych; przeciwdziałaniu uzależniania od pomocy społecznej, niezaradności życiowej; rosnącym wydatkom z budżetów"17.

Do podmiotów ekonomii społecznej w Polsce zaliczyć można chociażby: zakłady aktywności zawodowej (ZAZ), centra integracji społecznej (CIS), kluby integracji społecznej (KIS), spółdzielnie, organizacje pozarządowe, warsztaty terapii zajęciowej (WTZ), spółki non-profit.

Zakłady aktywności zawodowej (ZAZ) mogą być tworzone przez powiat, gminę, fundację, stowarzyszenie i inną organizację społeczną. Mogą one powstać na podstawie Ustawy z 27 sierpnia 1997 r. o rehabilitacji zawodowej i społecznej oraz o zatrudnieniu osób niepełnosprawnych, a także Rozporządzenia Ministra Pracy i Polityki Społecznej z 17 lipca 2012 r. w sprawie zakładów aktywności zawodowej. Celem tej organizacji jest podnoszenie poziomu życia osób niepełnosprawnych, a dokładniej wdrażanie ich w życie zawodowe i społeczne. Polska jest jednym z krajów o najniższym stopniu zatrudnienia osób niepełnosprawnych w Unii Europejskiej, dlatego też działania te są tak potrzebne. Każda

${ }^{16}$ E. Brzuska, I. Kukulak-Dolata, M. Wyka (red.), Ekonomia społeczna, teoria i praktyka przedsiębiorczości społecznej, Difin, Warszawa 2017, s. 11-13.

17 Cyt. za: A. Sobolewski, P. Klimek, J. Piekutowski (red.), Ekonomia społeczna w kreowaniu polityki lokalnej gmin i powiatów, Stowarzyszenie Czas Przestrzeń Tożsamość, Szczecin 2009, s. 9. 
osoba zgłaszająca się do ZAZ-u ma ułożony według własnych potrzeb program i harmonogram jego wykonywania. W zakładzie aktywności zawodowej co najmniej 70 procent zatrudnionych to osoby ze statusem niepełnosprawności, przy czym osoby z umiarkowanym stopniem niepełnosprawności nie mogą przekraczać 35 procent ogółu pracujących. Działalność ZAZ-u może być finansowana ze środków samorządu województwa w wysokości co najmniej 10 procent, ale przede wszystkim ze środków Państwowego Funduszu Rehabilitacji Osób Niepełnosprawnych ${ }^{18}$.

Centra integracji społecznej i kluby integracji społecznej zakładane są w oparciu o Ustawę z dnia 13 czerwca 2003 r. o zatrudnieniu socjalnym. Do instytucji tej przypisuje się szerszy krąg zainteresowanych w porównaniu do ZAZ-u. Ich celem jest przeciwdziałanie wykluczeniu społecznemu, jednak w szerszym zakresie niż wyżej opisanej instytucji. W kręgu ich zainteresowania są osoby długotrwale bezrobotne i bezdomne, niepełnosprawne, uzależnione, chore psychicznie, uchodźcy czy osoby zwalniane z zakładów karnych.

Centra integracji społecznej mogą powstawać w dwóch postaciach: samorządowej (funkcjonuje jako jednostka budżetowa lub samorządowy zakład budżetowy) i pozarządowej (wyodrębniona organizacyjnie i finansowo z koniecznością zgłoszenia do KRS). Status otrzymuje centrum po złożeniu wniosku do wojewody i jest on nadawany w drodze decyzji administracyjnej na okres 5 lat (istnieje możliwość przedłużenia, jeśli jednostka nieustannie pracuje i składa coroczne sprawozdania ze swojej działalności wojewodzie). CIS pomaga osobom dotkniętym wykluczeniem społecznym lub mogącym go doświadczyć, które nie mogą samodzielnie zaspokoić swoich podstawowych potrzeb. Osoby te mogą indywidualnie złożyć wniosek lub za pośrednictwem instytucji, tj. ośrodka pomocy społecznej, powiatowego centrum pomocy rodzinie, organizacji pozarządowych, KIS, instytucji zajmujących się leczeniem odwykowym. Podobnie jak w przypadku zakładu aktywności zawodowej centra oferują specjalny program, który określa zakres pomocy i jej formy. Osoba korzystająca z pomocy centrum otrzymuje świadczenie na poziomie zasiłku dla bezrobotnych. Cały okres trwania pomocy to 12 miesięcy (w tym miesiąc okresu próbnego). Po ukończeniu programu osoba zostaje skierowana do PUP, zatrudniona w CIS lub skierowana do konkretnego pracodawcy.

Kluby integracji społecznej tworzone są przez gminę lub organizację pozarządową, która w swych działaniach bierze pod uwagę kwestie integracji zawodowej i społecznej. Niezbędny do rozpoczęcia działalności takiej instytucji jest wpis do rejestru dokonywany na podstawie zgłoszenia podmiotu, który chce go otworzyć, i zatwierdzony przez wojewodę. KIS-y wspomagają te same grupy społeczne co CIS-y. Finansowanie tej organizacji jest zapewnione dzięki środkom z Unii Europejskiej lub dotacji z dochodów własnych gminy. Pomaga ona w: znalezieniu pracy, sprawach mieszkaniowych i socjalnych oraz zajmuje się poradnictwem prawnym ${ }^{19}$.

Samorząd terytorialny wyróżnia się wśród podmiotów publicznych szerokim zakresem stosowania zasad ekonomii społecznej. Wynika to z podstawowej zasady zarządzania publicznego, jaką jest subsydiarność. W uproszczeniu oznacza ona pomoc, jaką organy władzy centralnej powinny świadczyć jednostkom organizacyjnym w niższych struktu-

${ }^{18}$ E. Brzuska, I. Kukulak-Dolata, M. Wyka, dz. cyt., s. 30-34.

19 Tamże, s. 35-40. 
rach w realizacji zadań zaspokajających potrzeby obywateli. Interwencjonizm państwowy (uwzględniany także w ramach ekonomii społecznej) w świetle doktryny pomocniczości powinien dotyczyć przede wszystkim gmin, których administracja znajduje się najbliżej obywateli, dzięki czemu najlepiej rozpoznaje ich potrzeby ${ }^{20}$. Najbardziej klarowna definicja subsydiarności sprowadza się do formuły: tyle władzy, na ile to konieczne, tyle wolności, na ile to możliwe, oraz tyle państwa, na ile to konieczne, tyle społeczeństwa, na ile to możliwe. Stosowanie tych zasad w relacji jednostka-państwo ma pomóc w określeniu właściwych proporcji między tym, co żywiołowe i oddolne, a tym, co normowane odgórnie.

Podejmowanie decyzji na najniższym poziomie oznacza efektywną alokację ${ }^{21}$. Jednostki samorządu terytorialnego poprzez swoje działania finansowe odpowiadają za dostarczanie tych dóbr, dla których rynkowa (prywatna) alokacja jest zawodna. Gminy wydają najwięcej na oświatę i wychowanie oraz pomoc społeczną. Z kolei w stymulacji działalności gospodarczej gminy mają szansę korzystać z atutu lokalizacji i z gospodarczego modelu przyciągania polegającego na zachęcaniu inwestorów ulgami podatkowymi, tworzeniu stref ekonomicznych, obszarów strategicznych, porozumień gminnych, budowie infrastruktury ${ }^{22}$. W ten sposób mimo zmiennych uwarunkowań makroekonomicznych gminy mogą oddziaływać na przebieg procesu i zjawisk gospodarczych na swym terenie. Odbywa się to poprzez zarządzanie rozwojem lokalnym, czyli procesem informacyjno-decyzyjnym, polegającym na koordynacji harmonizującej działania różnych osób i instytucji oraz podmiotów. Takie zarządzanie opiera się na wielu instrumentach, które dzięki konsensusowi społecznemu mogą być wykorzystane w procesie interwencjonizmu lokalnego ${ }^{23}$.

Istotnym elementem wdrażania gospodarczych wizji, które na poziomie gminnym uwzględniają zasady ekonomii społecznej, jest przygotowanie strategii rozwoju. W jej współtworzeniu uczestniczą władze samorządowe, eksperci, przedstawiciele środowisk lokalnych, politycznych, gospodarczych i społecznych. W ten sposób gminna strategia opiera się na „czterech kapitałach”: gospodarczym, naturalnym, ludzkim i społecznym²4. Skuteczność strategii związana jest z przyjęciem zasady zrównoważonego rozwoju, w której zaspokajanie potrzeb nie odbywa się kosztem środowiska naturalnego i rozwoju przyszłych pokoleń. Do realizacji strategii samorząd powołuje specjalne agencje, spółki, związki partnerskie. Szerokie możliwości stwarza partnerstwo publiczno-prywatne, stosowane w Polsce zwłaszcza od czasu integracji z $\mathrm{UE}^{25}$.

20 J. Sługocki, Zasada subsydiarności poziomej $w$ teorii i w praktyce, [w:] B. Filipiak, A. Szewczuk, Samorząd terytorialny $w$ zintegrowanej Europie, t. 2, Wydawnictwo Naukowe Uniwersytetu Szczecińskiego, Szczecin 2006, s. 198-199.

21 A. Piasecki, Samorząd terytorialny $i$ wspólnoty lokalne, PWN, Warszawa 2009, s. 41.

22 J.J. Parysek, Podstawy gospodarki lokalnej, Wydawnictwo Naukowe Uniwersytetu im. Adama Mickiewicza, Poznań 2001, s. 58.

${ }^{23}$ M. Kogut, Oddzialywanie samorządu lokalnego na rozwój gospodarczy - istota i kryteria doboru instrumentów interwencjonizmu lokalnego, „Zeszyty Naukowe Uniwersytetu Szczecińskiego” 2006, nr 426, s. 233.

24 A. Płoszaj, ,, Cztery kapitały” w strategiach lokalnych, [w:] G. Gorzelak (red.), Polska regionalna i lokalna w świetle badań EUROREG-u, Wydawnictwo Naukowe „Scholar”, Warszawa 2007.

25 B. Zagożdżon, Partnerstwo publiczno-prywatne jako zalecany przez UE system finansowania inwestycji, „Samorząd Terytorialny” 2004, nr 9. 
Koncepcja partnerstwa w sposób operacyjny wiąże zasady ekonomii społecznej z priorytetami gminnego samorządu. Opiera się ona na powiązaniach między usługodawcami publicznymi a prywatnymi, w wyniku których obie strony wnoszą specyficzny wkład do wspólnego procesu świadczenia usług. W takim układzie stronę publiczną reprezentuje rząd (lub jego agencje), samorząd terytorialny albo regionalne fundusze. Po drugiej stronie mogą być wszystkie te podmioty, które są zainteresowane realizacją przedsięwzięć publicznych: firmy, przedsiębiorcy, mieszkańcy. Realizacja współpracy odbywa się na podstawie wieloletniej umowy cywilnoprawnej. W 2017 roku podpisano 113 takich umów o wartości 5,6 mld zł. Najmniejsza wartość przedsięwzięcia w ramach partnerstwa publiczno-prywatnego wyniosła 50 tys. zł (Wioska Kulinarna w Podcierniu), najdroższa dotyczyła budowy spalarni w Poznaniu w ramach Systemu gospodarki odpadami dla miasta $(925 \mathrm{mln} \text { zł })^{26}$.

W pierwszych kadencjach odrodzonego samorządu inwestycje gminne, które wpisują się w cele ekonomii społecznej, dotyczyły najczęściej infrastruktury lokalnej. Chodziło w nich o likwidację głównych barier dalszego rozwoju gospodarczego, na przykład poprzez stworzenie sieci wodociągów i kanalizacji. W ślad za tym szły inwestycje ekologiczne, tym bardziej że umożliwiały to publiczne fundusze gromadzone w ramach specjalnego funduszu. Pod koniec lat dziewięćdziesiątych udział gmin w nakładach inwestycyjnych na ochronę środowiska wynosił ponad $35 \%$, podczas gdy gminne budżety stanowiły poniżej $2 \%$ ich finansowania ${ }^{27}$. Bez takich inwestycji nie był możliwy zrównoważony rozwój.

Inwestycje komunalne miały na celu przede wszystkim podniesienie jakości życia mieszkańców. Dotyczyło to między innymi budownictwa mieszkaniowego, którego deficyt powodował w lokalnych wspólnotach zjawisko deprywacji. Już od 1995 roku specjalną ustawą rząd wspierał inicjatywy budowy tanich mieszkań czynszowych w ramach Towarzystwa Budownictwa Społecznego. Dwadzieścia lat później nowy impuls w tym zakresie dał program Mieszkanie Plus ${ }^{28}$. W XXI wieku z nowym podejściem do kwestii budownictwa (także mieszkaniowego) był zakrojony na szeroką skalę proces rewitalizacji.

W programach modernizacji starych części miasta czynnik społeczny odgrywa dużą rolę. Podstawą jest zawsze wszechstronne rozpoznanie potrzeb mieszkańców, umożliwienie niektórym z nich bezpośredniego uczestnictwa (w ramach partnerstwa publiczno-prywatnego). O skali programu Rewitalizacja Miast Polskich świadczy 12-tomowe wydawnictwo (pod takim właśnie tytułem) oraz I Kongres zorganizowany w Krakowie w czerwcu 2010 roku. Programy rewitalizacyjne z wykorzystaniem środków unijnych poza miastami wojewódzkimi realizowały między innymi: Aleksandrów Łódzki, Barwinów, Będzin, Bielsko-Biała, Chrzanów, Częstochowa, Działdowo, Gliwice, Głogów, Kędzierzyn-Koźle, Libiąż, Mielec, Nysa, Olecko, Otwock ${ }^{29}$, Pińczów, Pleszew, Przemyśl, Radom, Słupsk, Stary Sącz, Świecie, Tarnów, Tomaszów Lubelski, Trzebinia, Turek, Wałbrzych, Włoszczowa, Zakopane,

${ }^{26}$ J. Kamińska, Samorządy przekonuja się do PPP, „Wspólnota” 2018, nr 5.

${ }^{27}$ J. Kot, Rola inwestycji jednostek samorzadu terytorialnego w rozwoju gospodarczym regionu, [w:] A. Harańczyk (red.), Samorząd terytorialny: zadania - gospodarka - rozwój, Wyższa Szkoła Przedsiębiorczości i Marketingu w Chrzanowie, Chrzanów 2001, s. 169.

${ }^{28}$ Ł. Maryniak, Towarzystwa budownictwa społecznego - nowa stara forma, „Wspólnota” 2016, nr 20.

29 J. Król, Rewitalizacja zmienia i miasto, i ludzi, „Wspólnota” 2016, nr 15. 
Żyrardów, Żywiec ${ }^{30}$. Wszędzie tam wraz z unowocześnieniem infrastruktury nastąpiło jej uspołecznienie.

Warto przyjrzeć się dokładnie jednemu z takich projektów, zrealizowanemu w Turku, gdzie z małego Muzeum Rzemiosła Tkackiego stworzono kilkakrotnie większy obiekt, co zostało połączone z renowacją ratusza i zakupem dzieł Józefa Mehoffera. Realizacja projektu wykreowała nowy produkt kultury: ,Turek - miasto w klimacie Mehoffera”. Nazwa ta odzwierciedla kompleksowość projektu, który nie ogranicza się do bezpośredniej interwencji, ale służy wykorzystaniu kulturowego, edukacyjnego i turystycznego potencjału miasta. Unikalność projektu polega na tym, że nie ma na świecie miejsca o tak dużym skumulowaniu dzieł związanych z mistrzem Mehofferem. Projekt cechuje komplementarność, tzn. eksponaty znajdujące się w muzeum i prace wykonane w pobliskim kościele stanowią doskonale uzupełniający się produkt kulturowy. Zwiększyła się estetyka centrum miasta zlokalizowanego $\mathrm{w}$ przestrzeni urbanistycznej między ratuszem miejskim będącym siedzibą muzeum a kościołem. Wzmocniona została tożsamość mieszkańców Turku identyfikująca się z jego historią i kulturą. Nośne hasło marketingowe „Turek - miasto w klimacie Mehoffera" wpłynęło na zwiększenie zainteresowania turystyczną i kulturową ofertą miasta ${ }^{31}$.

Rewitalizacyjne inwestycje samorządów gminnych wpisują się w działania z zakresu ekonomii społecznej. W takich kategoriach można ocenić rewitalizację szpitala w Krotoszynie $^{32}$, budowę przystani jachtowej w Sopocie, remont zabytkowych fortyfikacji na Helu, Światowe Centrum Leczenia Częściowej Głuchoty w Nadarzynie, Europejskie Centrum Bajki im. Koziołka Matołka w Pacanowie, Rybnickie Centrum Kultury, rozwój regionu granicznego przez wspólną promocję i budowę Domu Polsko-Słowackiego w Czyrnej, Pasterski Szlak Papieski z infrastrukturą towarzyszącą Gminie w Węgierskiej Górce, Przebudowę Wiejskiego Domu Kultury w Jabłoniu, hotele w Elblągu, Iławie, Ostródzie, Kętrzynie, Lidzbarku Warmińskim ${ }^{33}$.

Połączenie misyjnej działalności samorządu terytorialnego (zaspokajanie potrzeb członków wspólnoty lokalnej) oraz rozbudowanych zasad ekonomii społecznej widoczne jest zwłaszcza na gruncie ekologii. To w tym obszarze mamy szeroko rozumiane stosowanie zrównoważonego rozwoju w sensie przestrzennym i czasowym. W tym kontekście szczególną rolę odgrywa gospodarka odpadami komunalnymi. Zajmujące się tym spółki gminne są mocno zakorzenione w lokalnej społeczności, tworzą stabilne miejsca pracy, a przede wszystkim, poza normalną działalnością gospodarczą, kładą nacisk na edukacyjny element swojej współpracy z mieszkańcami. Niektóre z nich po wysortowaniu odpadów sprzedają paliwa alternatywne ${ }^{34}$.

Poza gospodarką odpadami ekologiczne projekty samorządów miejskich obejmują zrównoważoną mobilność (ekologiczna komunikacja miejska, rowery), efektywność energetyczną budynków (termomodernizacja), gospodarkę wodną (stan zanieczyszczeń ujęć wody), za-

${ }^{30}$ W. Siemiński, T. Topczewska, Rewitalizacja miast w Polsce przy wsparciu funduszy UE w latach 2004-2008, Difin, Warszawa 2009.

${ }^{31}$ Na podstawie informacji uzyskanych od zastępcy burmistrza miasta Turku Mirosława Mękarskiego.

32 J. Kamińska, Rusza rewitalizacja szpitala w Krotoszynie, „Wspólnota” 2018, nr 2.

${ }_{33}$ Opracowano na podstawie prac magisterskich dotyczących wykorzystania środków unijnych oraz artykułu Wielkie projekty małych ojczyzn, „Eurofundusze”, dodatek do „Gazety Wyborczej”, 23 marca 2010.

34 J. Król, Nasza spótka przysporzyła miastu majątku, „Wspólnota” 2016, nr 9. 
rządzanie lokalnymi systemami energetycznymi ${ }^{35}$. W ramach programu „Polsko-norweska platforma współpracy dla poszanowania energii i klimatu” kilka samorządów otrzymało specjalne granty: Lublin na racjonalne wykorzystanie energii; Bielsko-Biała - na budowę ośrodka szkoleniowo-badawczego w zakresie odnawialnych źródeł energii i budownictwa energooszczędnego; Bydgoszcz - na Laboratorium Czystej Energii, Rumia - na innowacyjny system zaopatrzenia w energię elektryczną, ciepło i chłód części miasta; Płońsk - na program w stronę miasta zeroemisyjnego; Pałecznica - na Inteligentny Dom w Inteligentnej Wiosce; Raciechowice - na montaż pomp ciepła zasilanych z instalacji fotowoltaicznych w wybranych budynkach użyteczności publicznej; Sztum - na blisko zeroemisyjne budynki mieszkalne, termomodernizacje budynków wielorodzinnych przy zaangażowaniu mieszkańców z zastosowaniem innowacyjnych instalacji OZE; Sopot - na kompleksowe analizy i badania rynku związane z przygotowaniem i wdrożeniem pilotażowego projektu „Kompleksowa modernizacja energetyczna budynków użyteczności publicznej w Sopocie"36. W szeregu miast (Gdynia, Konic, Jarocin, Mielno, Głowno, Ostrów Wielkopolski) powstają plany mobilności, których istota polega na usprawnieniu komunikacji publicznej, ograniczeniu roli samochodu i popularyzacji roweru jako środka transportu. Taki plan to nie tylko działanie planistyczne, ale i narzędzie oddziaływania na świadomość społeczną poprzez inwestycje i całą politykę ekonomiczno-informacyjną ${ }^{37}$.

Wiele powyższych inicjatyw nabiera z czasem dynamicznego charakteru, łącząc społeczne wsparcie z samorządowymi priorytetami budżetowymi. Dotyczy to na przykład roweru miejskiego, którego liczba wypożyczeń w 2016 roku w skali kraju przekroczyła $10 \mathrm{mln}^{38}$. Bardziej innowacyjny charakter ma uruchamianie w miastach publicznych punktów dostępu do Internetu, tzw. hotspota ${ }^{39}$. Na obszarach wiejskich priorytetem jest dofinansowanie ze środków publicznych instalacji służących pozyskiwaniu energii odnawialnej ${ }^{40}$. To tylko niektóre przykłady wdrażania przez samorząd lokalny zasad zrównoważonego rozwoju, które leżą u podstaw ekonomii społecznej. Wśród polskich miast na prawach powiatu miano najbardziej „zrównoważonych” w rozwoju uzyskały kolejno: Warszawa, Sopot, Bielsko-Biała, Gdańsk, Kraków, Poznań, Koszalin, Wrocław, Bydgoszcz, Gdynia ${ }^{41}$.

W polityce społeczno-gospodarczej polskich gmin wśród wielu projektów wpisujących się w cele ekonomii społecznej szczególne znaczenie (również z powodów politycznych) ma współpraca z organizacjami pozarządowymi oraz inne przejawy zagospodarowania aktywności obywatelskiej. Badania pokazują spore zróżnicowanie w takich kwestiach, jak frekwencja wyborcza, działalność fundacji i stowarzyszeń, liczba zbiórek publicznych, zakres wsparcia finansowego dla $\mathrm{NGO}^{42}$. Organizacje pozarządowe w coraz większym stopniu realizują zadania publiczne, z kolei instytucje samorządowe częściej korzystają

${ }^{35}$ I twoje miasto może być Eko, „Wspólnota” 2016, nr 15.

36 A. Gniadowski, Zeroemisyjne miasta: utopia i moda, „Wspólnota” 2016, nr 22.

${ }^{37}$ K. Buczkowski, Gdynia pokazała swój Plan Zrównoważonej Mobilności Miejskiej, „Wspólnota” 2016, $\mathrm{nr} 22$.

${ }^{38}$ K. Buczkowski, Koszty i korzyści roweru miejskiego, „Wspólnota” 2016, nr 10.

39 S. Dąbek, Uruchomienie hotspota w gminie, „Wspólnota” 2016, nr 14.

${ }^{40}$ D. Krzysztofowicz, Pakt dla wsi, „Wspólnota” 2016, nr 10.

${ }^{41}$ J. Kamińska, Warszawa i Sopot najbardziej zrównoważone, „Wspólnota” 2016, nr 13.

${ }^{42}$ A. Miazga, P. Telsseyre, Społeczeństwo naprawdę obywatelskie, „Wspólnota” 2016, nr 10. 
z outsourcingu usług poprzez odejście od tworzenia jednostek organizacyjnych do realizacji zadań. Gminy mają ,zapewnić” konkretną usługę, ale niekoniecznie muszą ją bezpośrednio wykonywać. Wdrożenie licznych działań organizacji pozarządowych w misyjny charakter pracy jednostek samorządu terytorialnego sprzyja wzajemnej współpracy ocenianej bardziej w kategoriach jakościowych niż ilościowych ${ }^{43}$. Wśród miast, które w największym stopniu (w proporcji do liczby ludności) wspierają finansowo NGO są: Nowy Sącz, Przemyśl, Siedlce, Leszno, Legionowo, Konin, Ostrołęka, Zamość, Jelenia Góra, Piła.

Egzemplifikacja dotycząca ekonomii społecznej w Polsce może być bardzo rozbudowana. Warto jednak wskazać na najnowsze trendy, które pokazują kierunki wzmożonej aktywności samorządowych menedżerów. Można wybrać trzy przykłady takich obszarów ${ }^{44}$. Pierwszym jest tzw. srebrna polityka wynikająca z ogólnego procesu starzenia się społeczeństwa oraz wydłużającego się zachowania aktywności zawodowej i publicznej45. Możliwości gminy pokazuje Centrum Usług Społecznych w Oleśnicy, stanowiące nietypowe połączenie ośrodka opieki przedszkolnej, domu dziennego pobytu dla seniorów oraz kompleksu mieszkań chronionych z elementami klubu integracji społecznej. Wszystko to znajduje się w jednym wielokondygnacyjnym obiekcie ${ }^{46}$.

Drugim przykładem są tzw. karty miejskie. Taka karta ma zintegrować wiele usług oferowanych przez daną gminę (komunikacja miejska, parkowanie w strefie ograniczonego postoju, instytucje kulturalne itp.), jak i podmioty gospodarcze działające w tej jednostce administracyjnej. Są to różnorodne zniżki dla mieszkańców płacących tu podatki. W Krakowie jest to na przykład tańszy bilet w środkach komunikacji miejskiej, w Częstochowie zniżki w około 200 sklepach i punktach usługowych. Jest to swoisty program lojalnościowy wspierający rodzimych przedsiębiorców, usługodawców, handlowców ${ }^{47}$.

I wreszcie trzeci przykład będący ilustracją najnowszych priorytetów z tytułowej tematyki. Jest nim kapitał społeczny. Badania wykazują, że w jednostkach samorządu terytorialnego występują cztery typy instrumentów kapitału społecznego: 1) takie, które nie są związane z kapitałem społecznym i żaden poziom kapitału społecznego nie wzmacnia ich oddziaływania na przedsiębiorczość; 2) instrumenty, których występowanie nie jest ogólnie związane z kapitałem społecznym, ale wybrane poziomy kapitału społecznego wzmacniają ich oddziaływanie na przedsiębiorczość; 3) instrumenty, których występowanie jest ogólnie związane z kapitałem społecznym, ale żaden poziom kapitału społecznego nie wzmacnia ich oddziaływania na przedsiębiorczość; 4) instrumenty, których występowanie jest ogólnie związane z kapitałem społecznym, a wybrane poziomy kapitału społecznego wzmacniają ich oddziaływanie na przedsiębiorczośćc ${ }^{48}$.

${ }^{43}$ A. Dąmbska, Szorstka przyjaźń NGO i JST, „Wspólnota” 2018, nr 3.

${ }^{44}$ Metoda ,trzech aktów” była ulubioną formą prezentacji Steve’a Jobsa (C. Gallo, S. Jobs, Sztuka prezentacji, Znak, Kraków 2011, s. 17).

${ }^{4}$ J. Podgórska-Rykała, Rola samorzadów w kreowaniu $i$ wdrażaniu polityki senioralnej-przykład miasta Sosnowca, „Samorząd Terytorialny” 2018, nr 1-2.

${ }^{46}$ M. Kołaciński, Pomyst Oleśnicy na srebrna polityke, „Wspólnota” 2016, nr 2.

47 S. Bukowski, Częstochowa nagradza swoich mieszkańców, „Wspólnota” 2018, nr 2.

${ }^{48}$ E. Inglot-Brzęk, T. Skica, Kapitat społeczny jako czynnik determinujący skuteczność instrumentów wspierania przedsiębiorczości, „Samorząd Terytorialny” 2017, nr 7-8. 


\section{Podsumowanie}

Ekonomia społeczna stanowi system instytucjonalno-organizacyjno-prawny, którego zasady nierozłącznie wiążą się z samorządem terytorialnym. W Polsce na poziomie województwa widoczne jest to w programach działania (strategiach), a w samorządzie powiatowym w większym stopniu wdrażają to instytucje (na przykład do spraw bezpieczeństwa). Jednak najwięcej zadań z zakresu ekonomii społecznej realizowanych jest w gminach, gdzie głównym celem samorządowych inicjatyw jest zaspokojenie podstawowych potrzeb egzystencjalnych człowieka. Odbywa się to zarówno poprzez planowanie ${ }^{49}$, jak i szeroką partycypację obywatelską. Skutkuje zwiększeniem kapitału społecznego i przeciwdziałaniem wykluczeniu. Wpisuje się w ogólną politykę gospodarczą państwa.

Badania naukowe na ten temat nie tylko wzbogacają naszą wiedzę o otaczającej rzeczywistości, ale uczą umiejętności wartościowania zachodzących procesów gospodarczych, politycznych i prawnych. W efekcie tworzone są nawyki koncentrowania się na zjawiskach empirycznych i utylitarnego wykorzystania naukowych ustaleń.

\section{Bibliografia}

\section{Akty prawne}

Uchwała nr 164 Rady Ministrów z dnia 12 sierpnia 2014 r. w sprawie przyjęcia programu pod nazwą „Krajowy Program Rozwoju Ekonomii Społecznej”, M.P. 2014, poz. 811.

\section{Literatura}

Balcerzak-Parandowska B., Rączaszek A., Międzynarodowa polityka społeczna - aspekty porównawcze, IPSS, Warszawa 2010.

Borzaga C., Santuari A., Przedsiębiorstwa społeczne we Włoszech. Doświadczenia spótdzielni społecznych, Ministerstwo Pracy i Polityki Społecznej, Warszawa 2005.

Brzuska E., Kukulak-Dolata I., Wyka M. (red.), Ekonomia społeczna, teoria i praktyka przedsiębiorczości spolecznej, Difin, Warszawa 2017.

Filipiak B., Szewczuk A., Samorzad terytorialny w zintegrowanej Europie, t. 2, Wydawnictwo Naukowe Uniwersytetu Szczecińskiego, Szczecin 2006.

Frączak P., Wygnański J.J. (red.), Polski model ekonomii społecznej. Rekomendacje dla rozwoju, Fundacja Inicjatyw Społeczno-Ekonomicznych, Warszawa 2008.

Gallo C., Jobs S., Sztuka prezentacji, Znak, Kraków 2011.

Gorzelak G. (red.), Polska regionalna i lokalna w świetle badań EUROREG-u, Wydawnictwo Naukowe „Scholar”, Warszawa 2007.

Harańczyk A. (red.), Samorząd terytorialny: zadania - gospodarka - rozwój, Wyższa Szkoła Przedsiębiorczości i Marketingu w Chrzanowie, Chrzanów 2001.

\footnotetext{
${ }^{49}$ M. Karpiuk, Udziat czynnika społecznego w procesie sporzadzania miejscowego planu zagospodarowania przestrzennego, „Samorząd Terytorialny” 2017, nr 1-2.
} 
Kot J., Rola inwestycji jednostek samorzadu terytorialnego w rozwoju gospodarczym regionu, [w:] A. Harańczyk (red.), Samorząd terytorialny: zadania-gospodarka-rozwój, Wyższa Szkoła Przedsiębiorczości i Marketingu w Chrzanowie, Chrzanów 2001.

Kwiatkowski J., Ekonomia społeczna: moda czy remedium? Wprowadzenie do dyskusji, [w:] J. Kwiatkowski, A. Okraszewska (red.), Ekonomia społeczna: moda czy remedium?, FRDL Małopolski Instytut Samorządu Terytorialnego i Administracji w Krakowie, Kraków 2008.

Kwiatkowski J., Okraszewska A. (red.), Ekonomia społeczna: moda czy remedium?, FRDL Małopolski Instytut Samorządu Terytorialnego i Administracji w Krakowie, Kraków 2008.

Murzyn D., Pach J. (red.), Ekonomia społeczna, między rynkiem, państwem a obywatelem, Difin, Warszawa 2018.

Narski Z., Ekonomia społeczna, Wydawnictwo Adam Marszałek, Toruń 2012.

Pach J., Innowacyjność ekonomii społecznej w kontekście rozwiąywania problemów społeczno-gospodarczych, [w:] D. Murzyn, J. Pach (red.), Ekonomia społeczna, między rynkiem, państwem a obywatelem, Difin, Warszawa 2018.

Parysek J.J., Podstawy gospodarki lokalnej, Wydawnictwo Naukowe Uniwersytetu im. Adama Mickiewicza, Poznań 2001.

Piasecki A., Samorzą terytorialny i wspólnoty lokalne, PWN, Warszawa 2009.

Płoszaj A., ,, Cztery kapitały” w strategiach lokalnych, [w:] G. Gorzelak (red.), Polska regionalna i lokalna w świetle badań EUROREG-u, Wydawnictwo Naukowe „Scholar”, Warszawa 2007.

Podgórska-Rykała J., Rola samorządów w kreowaniu i wdrażaniu polityki senioralnej-przykład miasta Sosnowca, „Samorząd Terytorialny” 2018, nr 1-2.

Siemiński W., Topczewska T., Rewitalizacja miast w Polsce przy wsparciu funduszy UE w latach 2004-2008, Difin, Warszawa 2009.

Sługocki J., Zasada subsydiarności poziomej w teorii i w praktyce, [w:] B. Filipiak, A. Szewczuk, Samorzad terytorialny w zintegrowanej Europie, t. 2, Wydawnictwo Naukowe Uniwersytetu Szczecińskiego, Szczecin 2006.

Sobolewski A., Klimek P., Piekutowski J. (red.), Ekonomia społeczna w kreowaniu polityki lokalnej gmin i powiatów, Stowarzyszenie Czas Przestrzeń Tożsamość, Szczecin 2009.

Sztumski J., Aktualność idei sprawiedliwość społeczna w polityce społecznej, [w:] B. Balcerzak-Parandowska, A. Rączaszek (red.), Międzynarodowa polityka społeczna-aspekty porównawcze, IPSS, Warszawa 2010.

Tylec T., Ekonomia społeczna - idea i kierunki rozwoju koncepcji, [w:] D. Murzyn, J. Pach (red.), Ekonomia społeczna, między rynkiem, państwem a obywatelem, Difin, Warszawa, 2018.

\section{Prasa}

Buczkowski K., Gdynia pokazała swój Plan Zrównoważonej Mobilności Miejskiej, „Wspólnota” 2016, nr 22.

Buczkowski K., Koszty i korzyści roweru miejskiego, „Wspólnota” 2016, nr 10.

Bukowski S., Częstochowa nagradza swoich mieszkańców, „Wspólnota” 2018, nr 2.

Dąbek S., Uruchomienie hotspota w gminie, „Wspólnota” 2016, nr 14.

Dąmbska A., Szorstka przyjaźń NGO i JST, „Wspólnota” 2018, nr 3. 
Gniadowski A., Zeroemisyjne miasta: utopia i moda, „Wspólnota” 2016, nr 22.

I twoje miasto może być Eko, „Wspólnota” 2016, nr 15.

Inglot-Brzęk E., Skica T., Kapitał społeczny jako czynnik determinujący skuteczność instrumentów wspierania przedsiębiorczości, ,Samorząd Terytorialny” 2017, $\mathrm{nr} 7-8$.

Kamińska J., Rusza rewitalizacja szpitala w Krotoszynie, „Wspólnota” 2018, nr 2.

Kamińska J., Samorządy przekonują się do PPP, „Wspólnota” 2018, nr 5.

Kamińska J., Warszawa i Sopot najbardziej zrównoważone, „Wspólnota” 2016, nr 13.

Karpiuk M., Udział czynnika społecznego w procesie sporzadzania miejscowego planu zagospodarowania przestrzennego, ,Samorząd Terytorialny” 2017, nr 1-2.

Kogut M., Oddziaływanie samorządu lokalnego na rozwój gospodarczy-istota i kryteria doboru instrumentów interwencjonizmu lokalnego, „Zeszyty Naukowe Uniwersytetu Szczecińskiego" 2006, nr 426.

Kołaciński M., Pomyst Oleśnicy na srebrna politykę, „Wspólnota”2016, nr 2.

Król J., Nasza spółka przysporzyła miastu majątku, „Wspólnota” 2016, nr 9.

Król J., Rewitalizacja zmienia i miasto, i ludzi, „Wspólnota” 2016, nr 15.

Krzysztofowicz D., Pakt dla wsi, „Wspólnota” 2016, nr 10.

Maryniak Ł., Towarzystwa budownictwa społecznego - nowa stara forma, „Wspólnota” 2016, nr 20.

Miazga A., Telsseyre P., Społeczeństwo naprawdę obywatelskie, „Wspólnota” 2016, nr 10.

Wielkie projekty małych ojczyzn, „Eurofundusze”, dodatek do „Gazety Wyborczej”, 23 marca 2010.

Zagożdżon B., Partnerstwo publiczno-prywatne jako zalecany przez UE system finansowania inwestycji, „Samorząd Terytorialny” 2004, nr 9.

\section{Źródla internetowe}

Bugajski J., Ekonomia społeczna - nowość nie tylko polska, http://www.sprawynauki.edu.pl/ features/the-community/1443?task=view [dostęp: 8.02.2019].

Rivas de Roca García R., Galicja, kraina rozczarowanych młodych ludzi, https://cafebabel.com/ $\mathrm{pl} /$ article/galicja-kraina-rozczarowanych-mlodych-ludzi-5ae00b67f723b35a145e 7781/ [dostęp: 8.06.2018].

Sałustowicz P., Pojęcie, koncepcje i funkcje ekonomii społecznej, „Ekonomia Społeczna Teksty" 2/2007, http://www.ekonomiaspoleczna.pl/files/ekonomiaspoleczna.pl/public/Biblioteka/2007.13.pdf [dostęp: 24.05.2018].

Ekonomia społeczna, www.ekonomiaspoleczna.pl [dostęp: 8.06.2018]. 


\section{Streszczenie}

\section{Ekonomia społeczna w samorządzie terytorialnym}

Artykuł poświęcony jest ekonomii społecznej i jej zastosowaniu przez samorząd terytorialny. W pracy przytoczono przykłady z trzech państw, które stosują się do zasad gospodarki społecznej. Są to: Włochy, Hiszpania oraz Polska. W naszym państwie zadania ekonomii społecznej stosowane są szczególnie na poziomie gminy. Nadrzędnym celem jest likwidacja ubóstwa, bezrobocia, wykluczenia społecznego itp. Realizacja zasad ekonomii społecznej polega na opracowywaniu i wdrażaniu programów, niejednokrotnie długookresowych oraz ułatwianiu społeczeństwu dostępu do podstawowych dóbr. W artykule wykazano, że ekonomia społeczna związana jest z aktywnością obywateli i ich przedsiębiorczością, która w konsekwencji ma przynosić społeczne i ekonomiczne korzyści dla wszystkich osób zamieszkujących daną wspólnotę.

Słowa kluczowe: ekonomia społeczna; samorząd terytorialny; pomoc społeczna; gospodarka, pożytek publiczny; unowocześnienia; usprawnienie; fundacja; stowarzyszenie; spółdzielnia

\section{Summary}

\section{Social economy in local government}

This article is dedicated to the social economy and its adoption by local government. Examples from three countries which apply the rules of the social economy (Italy, Spain and Poland) are referred to. In Poland these principles are applied particularly at the municipal level. The main purpose of the social economy is the eradication of poverty, unemployment, social exclusion, etc. The implementation of social economy rules involves the development and adoption of long-lasting programs and the provision of basic goods for society. This article shows that the social economy is connected with citizens' activity and initiative. Consequently, it brings social and economic benefits for all people who live in a given community.

Keywords: social economy, local government, social assistance, economy, public benefit, modernization, rationalization, foundation, association, cooperative 
Sylwia Rapicka (iD https://orcid.org/0000-0003-3316-2084

Uniwersytet Pedagogiczny im. KEN w Krakowie, Wydział Politologii, Instytut Prawa, Administracji i Ekonomii

\section{Pomówienie w polityce. Wybrane aspekty prawne i empiryczne}

Przestępstwo pomówienia (używane jest też zamiennie określenie zniesławienie) istnieje w prawie karnym od wielu lat. Istniało już w kodeksie karnym z 1932 roku, miało swoje miejsce w kodeksie z 1969 roku i kontynuuje swój byt prawny w kodeksie aktualnym z 1997 roku. Zasadnicza konstrukcja prawna przepisów jest bardzo podobna, aczkolwiek ulegała kolejnym modyfikacjom, podobnie jak specyficzne zasady proceduralne.

Przez długie lata pomówienie stanowiło przestępczość ,niszową”, liczba postępowań karnych, rejestrowanych w statystyce kryminalnej (prowadzonej przez Komendę Główną Policji) oraz skazań utrzymywała się w przedziale około stu rocznie.

$\mathrm{Na}$ ogół obserwowany na przestrzeni lat mechanizm ścigania pomówień miał następujący schemat: jedna pani powiedziała o drugiej pani coś wielce niekorzystnego, ta - czując się zniesławiona - wnosiła sprawę do sądu. Sprawy takie, uzupełnione postępowaniami o przestępstwa podobne, na przykład znieważenie słowne lub czynne, bardzo lekkie uszkodzenia ciała, wśród pracowników wymiaru sprawiedliwości i palestry określane były nieco lekceważącym, żargonowym terminem pyskówka.

Równocześnie w ostatnich latach w praktyce wymiaru sprawiedliwości pojawiły się zupełnie nowe tendencje. Przepisy karne dotyczące pomówienia stały się swoistym elementem ,gry politycznej”, znacząca swoboda działalności medialnej spowodowała „odbicie” w kierunku rozgrywania na sali sądowej rzeczywistych czy mniemanych krzywd doznanych w publikacjach.

Swoistą cezurą prawną, ale i obyczajową okazał się znamienny fakt, iż dosłownie w dniu orzeczenia prawomocnego wyroku skazującego za pomówienie oskarżony (i skazany) odebrał z rąk prezydenta RP akt powołania na stanowiska wicepremiera i ministra. Notabene 
sam prezydent nieco wcześniej również przeszedł (nieukończoną ostatecznym wyrokiem) drogę oskarżonego z art. $212 \mathrm{kk}$. Los ten dotknął i dotyka wcale liczną rzeszę polityków z ,pierwszych stron gazet”. Z tym samym coraz częściej spotykają się dziennikarze i wydawcy, a wydawane w tych sprawach wyroki spotykają się z szerokim odzewem społecznym, publicystycznym oraz dyskusjami doktrynalnymi.

Takie ukierunkowanie rozważań pozwala na szukanie argumentacji i ścierających się poglądów w kilku niezmiernie istotnych kwestiach. Przede wszystkim w kwestii zakresu ochrony prawnej uprawnień konstytucyjnych w sferze swobody wypowiedzi w konfrontacji z prawem do ochrony prawnej dobrego imienia. Kolejną sprawą jest próba odpowiedzi na pytanie, czy skuteczna ochrona prawna wymaga sięgania po przepisy systemu prawa karnego, czy wystarczająca jest ochrona z systemu prawa cywilnego oraz jakie korelacje występują pomiędzy oboma ustawodawstwami. Niezmiernie ważne jest sięgnięcie do bogatego orzecznictwa Europejskiego Trybunału Praw Człowieka w Strasburgu, który wielokrotnie mierzył się z takimi sprawami i wypracował bardzo szerokie spektrum praktyki; ponadto do tego organu coraz częściej trafiają sprawy z Polski.

Ochrona czci przed bezprawnymi zamachami stanowi zagadnienie bardzo stare. Cześć, dobre imię, honor człowieka, zaufanie, jakim się cieszy, wywodzono nawet z ,praw naturalnych", w miarę upływu lat rozszerzając to pojęcie również do instytucji, osób prawnych, zrzeszeń, a nawet grup ludzi. Obecnie godność zyskała także rangę konstytucyjną, określoną w art. 30 Konstytucji: „Przyrodzona i niezbywalna godność człowieka stanowi źródło wolności i praw człowieka i obywatela. Jest ona nienaruszalna, a jej poszanowanie i ochrona jest obowiązkiem władz publicznych". Kolejne rozwinięcie tej zasady stanowi treść art. 47 Konstytucji: „Każdy ma prawo do ochrony prawnej życia prywatnego, rodzinnego, czci i dobrego imienia oraz do decydowania o swoim życiu osobistym".

Definicja deliktu pomówienia w aktualnych przepisach kodeksu karnego jest stosunkowo precyzyjna:

Art. $212 \S 1$. Kto pomawia inną osobę, grupę osób, instytucję, osobę prawną lub jednostkę organizacyjną niemającą osobowości prawnej o takie postępowanie lub właściwości, które mogą poniżyć ją w opinii publicznej lub narazić na utratę zaufania potrzebnego dla danego stanowiska, zawodu lub rodzaju działalności, podlega grzywnie, karze ograniczenia albo pozbawienia wolności do roku.

$\S 2$. Jeżeli sprawca dopuszcza się czynu określonego w $§ 1$ za pomocą środków masowego komunikowania, podlega grzywnie, karze ograniczenia wolności albo pozbawienia wolności do lat 2 .

$\S 3$. W razie skazania za przestępstwo określone w $\S 1$ lub 2 sąd może orzec nawiązkę na rzecz pokrzywdzonego, Polskiego Czerwonego Krzyża albo na inny cel społeczny wskazany przez pokrzywdzonego.

$\S 4$. Ściganie przestępstwa określonego w $§ 1$ lub 2 odbywa się z oskarżenia prywatnego. Art. $213 \S 1$. Nie ma przestępstwa określonego w art. $212 \S 1$, jeżeli zarzut uczyniony niepublicznie jest prawdziwy.

§ 2. Nie popełnia przestępstwa określonego w art. 212 § 1 lub 2, kto publicznie podnosi lub rozgłasza prawdziwy zarzut służący obronie społecznie uzasadnionego interesu; jeżeli zarzut dotyczy życia prywatnego lub rodzinnego, dowód prawdy może być przeprowadzony tylko wtedy, gdy zarzut ma zapobiec niebezpieczeństwu dla życia lub zdrowia człowieka albo demoralizacji małoletniego. 
Art. 214. Brak przestępstwa wynikający z przyczyn określonych w art. 213 nie wyłącza odpowiedzialności sprawcy za zniewagę ze względu na formę podniesienia lub rozgłoszenia zarzutu.

Art. 215. Na wniosek pokrzywdzonego sąd orzeka podanie wyroku skazującego do publicznej wiadomości.

W określeniach ustawowych, jak i wykładni doktrynalnej oraz praktyce orzeczniczej wytworzyły się szczególne formy zniesławienia:

- $\quad$ pomówienie - rozumiane jako zakomunikowanie chociażby jednej osobie wiadomości

o postępowaniu lub właściwościach innej osoby, mogącej poniżyć ją w opinii publicznej lub narazić na utratę zaufania ${ }^{1}$,

- $\quad$ oszczerstwo (potwarz) - złośliwe, celowe rozpowszechnianie wiadomości, które mogą poniżyć osobę pokrzywdzoną lub narazić na utratę zaufania².

Przedmiotem ochrony prawnej jest cześć - przysługujące każdemu domniemanie uczciwości, postępowania zgodnego z normami współżycia społecznego, należytych kompetencji i właściwości wykonywanego zawodu, pełnionej funkcji, braku przymiotów zasługujących na potępienie ${ }^{3}$.

Ochrona obejmuje każdą osobę, niezależnie od opinii, jaką posiada, nawet gdyby była pejoratywnie oceniana przez społeczeństwo (np. karana sądownie) czy wykonywała analogicznie pejoratywnie ocenianą profesję (np. prostytucji) ${ }^{4}$. Po równo ochronie podlegają osoby prawne, zrzeszenia, instytucje, grupy ludzi ${ }^{5}$.

Konkretyzując, za pomówienie można uważać rozpowszechnianie wobec osób trzecich zarzutów, które mogą kształtować ujemną, poniżającą opinię o pokrzywdzonym, jak również wpływać na obniżanie dotychczas dobrej opinii ${ }^{6}$.

Zniesławienie nie musi stawiać osoby pokrzywdzonej w ujemnym świetle z punktu widzenia zasad etyczno-moralnych, może natomiast podważać do tej osoby zaufanie, na przykład przez stwierdzenie: „rzemieślnik uczciwy, ale partacz”7.

Pomówienie musi mieć charakter wypowiedzi opartych na faktach, a nie na ocenach. Oceny bowiem nie są lub są bardzo trudne do weryfikacji. Z praktyki orzeczniczej ETPC wyraźnie wynika, że Trybunał staje na stanowisku, iż „wypowiedzi ocenne nie stanowią zniesławienia"; nic wszakże nie stoi na przyjęciu, że mogą wyczerpywać znamiona zniewagi, a więc innego przestępstwa ${ }^{8}$.

Faktyczne ,poniżenie” nie musi wystąpić, do bytu przestępstwa wystarczy bowiem, by istniało realne zagrożenie powstaniem poniżenia lub utraty zaufania. Jest bez znaczenia, czy przytaczane fakty mają charakter pochodzących ,z pierwszej ręki, czy pochodzą z za-

\footnotetext{
${ }^{1}$ Akty prawne, Katedra Prawa Karnego Procesowego i Kryminalistyki, https://prawo.ug.edu.pl/ wydzial/struktura wydzialu/katedry pracownie zaklady/katedra prawa karnego procesowego i kryminalistyki/zaklad kryminalistyki i prawa dowodowego/akty prawne [dostęp: 19.02.2019].

${ }^{2}$ O. Górniak (red.), Kodeks karny, komentarz, LexisNexis, Warszawa 2004, s. 644.

3 Tamże.

${ }^{4}$ A. Zoll (red.), Kodeks karny, część szczególna, t. 2, Zakamycze, Kraków 1999, s. 644.

5 J. Bafia, K. Mioduski, M. Siewierski, Kodeks karny, komentarz, Wydawnictwo Prawnicze, Warszawa 1977, s. 447.

${ }^{6}$ W. Kulesza, Zniestawienie i zniewaga, Wydawnictwo Prawnicze, Warszawa 1984, s. 35.

7 A. Zoll (red.), dz. cyt., s. 648.

${ }^{8}$ L. Gardocki, Prawo karne, Wydawnictwo C.H. Beck, Warszawa 1998, s. 257.
} 
słyszenia"; mogą także pochodzić z pogłosek, plotek, mogą stanowić wniosek z faktów lub zasłyszeń. O bycie przestępstwa decyduje fakt dotarcia z informacją do chociażby jednej osoby. Pomówienie wypowiadane wprost w kierunku pokrzywdzonego, bez jakiejkolwiek możliwości zapoznania się z nim innej osoby nie stanowi zniesławienia. Sprawca musi zarazem zdawać sobie sprawę, mieć pełną świadomość, że rozgłasza wiadomości mogące poniżyć osobę lub podważyć do niej zaufanie?.

Przestępstwo pomówienia ma charakter powszechny (a więc popełnić je może każdy), jest przestępstwem formalnym, bezskutkowym ${ }^{10}$.

Już od wejścia w 1932 roku w życie kk w praktyce zaczęły pojawiać się ogromne trudności interpretacyjne. Określenie znamion pomówienia jest de facto dalece niejasne, pozostawia równocześnie ogromne pole swobodnej interpretacji. Stosunkowo szybko stało się zatem przedmiotem licznego orzecznictwa sądowego, w tym orzecznictwa Sądu Najwyższego. Dążeniem było ujednolicenie interpretacji, stopniowo dążącej do zawężenia, a nawet ograniczenia zasięgu tego deliktu. Proces ten trwa zresztą do dziś, stopniowo coraz ostrzej definiując, jaki stan faktyczny nie jest uznawany za pomówienie. Pierwsza znacząca interwencja Sądu Najwyższego nastąpiła niespełna dwa lata od wejścia w życie kk. W orzeczeniu ZO IK 185/1934 ograniczono zasięg stosowania pomówienia, wyłączając spod niego następujące stany faktyczne:

- oświadczenia stanowiąca działanie w obronie naruszonych praw, a więc rozmaite skargi sądowe, pozwy, pisma do organów władzy, zawiadomienia o przestępstwach, zeznania świadków składane przed właściwymi organami, wyjaśnienia składane przez oskarżonych itp.,

- oświadczenia składane w ramach wykonywanych obowiązków służbowych, takie jak raporty policyjne, opinie pracownicze, referencje, czynności prokuratorów, policjantów, sędziów, adwokatów, urzędników państwowych itp.,

- oświadczenia będące uprawnieniem osoby do oceniania innych, na przykład polecenia i uwagi przełożonych w pracy, uwagi, karcenia oraz polecenia nauczycieli w stosunku do uczniów itp. ${ }^{11}$.

W okresie powojennym, podczas obowiązywania zarówno kk z 1932, jak i kk z 1969, zakres tych wyłączeń dalej rozszerzano. Do wspomnianych przesłanek negatywnych zaliczono krytykę artystyczną, literacką i naukową, orzeczenia sądów koleżeńskich, dyscyplinarnych itp., rozmaite opinie i referencje, charakterystyki zawodowe, a także skargi i zażalenia, wnioski w trybie regulowanym kpa itp. ${ }^{12}$.

Liczne spory toczyły się i toczą w zakresie oceny zeznań i wyjaśnień. Czy zeznanie świadka, składane (wszak pod rygorem odpowiedzialności karnej za zeznanie nieprawdy), a już szczególnie wyjaśnienia oskarżonych (podejrzanych) mogą stanowić podstawę prawną do przyjęcia ich za pomówienie? Oskarżonemu przysługuje prawo do obrony, nawet poprzez świadome kłamstwo. Jeśli zatem pomawia on inne osoby, zrzucając na nie podejrzenia, ujemnie oceniając ich role itd., to czy może zostać dodatkowo oskarżony za zniesławienie?

\footnotetext{
9 J. Bafia, K. Mioduski, M. Siewierski, dz. cyt., s. 448.

${ }^{10}$ A. Zoll (red.), dz. cyt., s. 648.

11 L. Gardocki, Prawo..., dz. cyt., s. 257.

12 J. Bafia, K. Mioduski, M. Siewierski, dz. cyt., s. 448.
} 
Ogólny pogląd przemawia za oceną okoliczności - jeśli jest to ewidentna forma obrony, związana z postępowaniem, wówczas nie ma mowy o zarzucie pomówienia ${ }^{13}$.

Ograniczenie stosowania pomówienia dotyczy również kwestii publicznego charakteru czynu - ocena istotna $\mathrm{z}$ uwagi na tryb kwalifikowany prowadzony w nowym kodeksie (art. 212 § 2). Przez „środki masowego przekazu” rozumieć należy: prasę, radio, telewizję, internet, możliwość rozplakatowania ogłoszeń, ulotek. Charakter publiczny mogą mieć także wystąpienia na wiecach i zebraniach publicznych, nagłośnienie itp. ${ }^{14}$

Nie może być uznane za działanie ,publiczne” skierowanie pisma do organu władzy, z którym zapoznaje się pewna liczba osób w ramach wykonywania obowiązków służbowych w zakresie ich kompetencji (OSNKW z. 1, poz. 6, z 1976 r.). Przyjmuje się również, że nie można zniesławić osoby nieżyjącej, chyba że pomówienie jest ewidentnie skierowane na chęć poniżenia czy podważenia zaufania do żyjących antenatów zmarłego ${ }^{15}$.

Zagadnienie odrębne stanowi stopniowe ograniczenie osób, które mogą być narażone czy pokrzywdzone zniesławieniem. Niezmiernie istotna staje się tu praktyka ETPC. Znaczące ograniczenia ochrony dotyczą osób publicznych, głównie polityków, ale także funkcjonariuszy publicznych. Tolerancja ,wrażliwości” jest tutaj przyjmowana jako znacznie ograniczona. Istnieje bowiem znaczący konflikt pomiędzy zasadą ochrony czci a prawem do krytyki i swobody wypowiedzi - czynnikami o niezwykłej doniosłości w życiu demokratycznych społeczeństw ${ }^{16}$.

Proces definiowania, interpretowania, ograniczeń przedmiotowych i podmiotowych w zakresie przestępstwa pomówienia rozwija się coraz intensywniej, do czego przyczynia się zarówno bieżąca praktyka orzecznicza, zaczątki rozstrzygnięć Trybunału Konstytucyjnego w tym zakresie, a także orzecznictwa ETPC. Przykładów dostarczają także inne kraje, w tym zrzeszone w rodzinie europejskiej (ale również pozaeuropejskie), które stopniowo ograniczają, a nawet wręcz depenalizują, to uregulowanie karne.

Postępowania karne w przedmiocie przestępstwa pomówienia podlegają nieco odrębnym zasadom proceduralnym. Generalną zasadą (wynikającą zresztą z prawa materialnego) jest ściganie go w trybie oskarżenia prywatnego, a więc ustawodawca oddał całkowicie inicjatywę wejścia na drogę postępowania karnego pokrzywdzonemu, zapewne w mniemaniu, że skoro czuje się zagrożony zniesławieniem, to powinien sam dochodzić swoich praw przed sądem.

Obecne przepisy kpk dają - jako wyjątek - możliwość prokuratorowi objęcia postępowania karnego odnośnie do pomówienia ściganiem z urzędu (art. $60 \mathrm{kpk}$ ), ale wyłącznie w przypadkach, gdy wymaga tego interes społeczny. Codzienna praktyka prokuratury wskazuje, że powszechnym zwyczajem jest oddalanie wniosków o wspomniany tryb. Przypadki ścigania z urzędu takich spraw należą do wyjątkowo rzadkich. Znacząca różnica dotyczy kwestii dowodowych. Chociaż przed laty zrezygnowano z zasady (wyrażonej w art. 255 $\S 2$ kk z 1932 r.) przedmiotowego ograniczenia możliwości dowodowych (zakazu dowodowego), to istotną różnicę stanowi przepis art. $213 \S 1 \mathrm{kk}$. Przepis ten wyraźnie przesuwa

\footnotetext{
13 A. Zoll (red.), dz. cyt., s. 648; L. Gardocki, Zniestawienie, „Palestra” 1994, nr 3-4, s. 55 i nast.

14 L. Gardocki, Prawo..., dz. cyt., s. 257-258.

15 J. Bafia, K. Mioduski, M. Siewierski, dz. cyt., s. 449.

16 Tamże, s. 450-451.
} 
ciężar dowodu na oskarżonego. Tworzy to sytuację, że to nie oskarżyciel (pokrzywdzony) ma udowodnić nieprawdziwość zarzutu, ale oskarżony zmuszony jest do udowodnienia prawdziwości zarzutu, będącego osnową aktu oskarżenia. Wedle wykładni doktrynalnej wątpliwości co do prawdziwości zarzutu niwelują zasadę domniemania niewinności sprawcy, więc przewagę zyskuje domniemanie dobrego imienia pokrzywdzonego (oskarżyciela) ${ }^{17}$.

Powstaje jednak pytanie, co z konstytucyjną zasadą domniemania niewinności, wyrażoną w art. 42, pkt 3 Konstytucji w słowach: „Każdego uważa się za niewinnego, dopóki jego wina nie zostanie stwierdzona prawomocnym wyrokiem sądu".

Tu pojawiają się zasadnicze spory doktrynalne. Zasada domniemania niewinności w sposób kategoryczny zrzuca ciężar dowodu na oskarżyciela. Oskarżony może we własnej obronie nie wykonać nawet najmniejszego ruchu. Jeśli oskarżyciel nie przeprowadzi skutecznego dowodu winy, wówczas wina zostaje nieudowodniona, a więc obowiązkiem sądu jest wydanie werdyktu uniewinniającego. Twierdzeń oskarżonego (i jego obrońcy) nie można automatycznie odrzucać. Jeśli nie uda się tego zrobić, należy je uznać za prawdziwe. Oskarżonemu przysługuje wprawdzie prawo dowiedzenia swojej niewinności, ale nie ma procesowego obowiązku tego czynić1 ${ }^{18}$.

Z drugiej strony konstrukcja prawna przepisów - art. 179 § 1 i 2 kk z 1969 r. i art. 213 § 1 i 2 kk niejako narzuca konieczność przeprowadzenia dowodu prawdy twierdzeń zawartych w treści zniesławienia, co logicznie i faktycznie przerzuca ciężar dowodu na oskarżonego, niejako zmuszając go do aktywnej (a nie biernej) obrony. Przy absolutnie ścisłej interpretacji zasady domniemania niewinności to oskarżyciel mógłby być zmuszony do prowadzenia dowodu prawdy, że nie jest na przykład łapownikiem, złodziejem ${ }^{19}$.

Jak dotąd kwestia ta nie została poddana pod ocenę Trybunału Konstytucyjnego. Cześć, godność, dobre imię człowieka (instytucji) korzystają ze szczególnej ochrony cywilnoprawnej, wyrażonej w art. 23 i 24 kc:

- $\quad$ Art. 23. Dobra osobiste człowieka, jak w szczególności zdrowie, wolność, cześć, swoboda sumienia, nazwisko lub pseudonim, wizerunek, tajemnica korespondencji, nietykalność mieszkania, twórczość naukowa, artystyczna, wynalazcza i racjonalizatorska, pozostają pod ochroną prawa cywilnego niezależnie od ochrony przewidzianej $\mathrm{w}$ innych przepisach.

- $\quad$ Art. 24 § 1. Ten, czyje dobro osobiste zostaje zagrożone cudzym działaniem, może żądać zaniechania tego działania, chyba że nie jest ono bezprawne. W razie dokonanego naruszenia może on także żądać, ażeby osoba, która dopuściła się naruszenia, dopełniła czynności potrzebnych do usunięcia jego skutków, w szczególności złożyła oświadczenie odpowiedniej treści i w odpowiedniej formie. Na zasadach przewidzianych w kodeksie może on również żądać zadośćuczynienia pieniężnego lub zapłaty odpowiedniej sumy pieniężnej na wskazany cel społeczny:

- $\quad \S 2$. Jeżeli wskutek naruszenia dobra osobistego została wyrządzona szkoda majątkowa, poszkodowany może żądać jej naprawienia na zasadach ogólnych.

\footnotetext{
${ }^{17}$ A. Zoll (red.), dz. cyt., s. 647.

18 O. Górniak, dz. cyt., s. 645.

19 A. Zoll (red.), dz. cyt., s. 649.
} 
- $\quad \S 3$. Przepisy powyższe nie uchybiają uprawnieniom przewidzianym w innych przepisach, w szczególności w prawie autorskim oraz w prawie wynalazczym.

Gdy dokonamy porównawczej egzegezy przepisów kodeksu cywilnego i art. 212 kk, nie ulega wątpliwości, że zasięgiem ochrony prawnej są one zbliżone. Można dojść do jednoznacznego wniosku, że każde pomówienie stanowi naruszenie dóbr osobistych (odwrotnie już nie).

Dobra osobiste stanowią zarazem zakres pojęć o wiele szerszych niż stosunkowo ostro zdefiniowany zakres ochrony z systemu prawa karnego. Do dóbr osobistych zalicza się w szczególności: zdrowie, wolność, cześć, swobodę zamieszkania, nazwisko lub pseudonim, wizerunek, tajemnicę korespondencji, nietykalność mieszkania, twórczość naukową, artystyczną, wynalazczą i racjonalizatorską ${ }^{20}$.

Szczególna korelacja występuje w sferze naruszenia czci. Może ona nastąpić przez pomówienie o ujemne postępowanie w życiu osobistym i rodzinnym, jak i przez zarzucenie niewłaściwego postępowania w życiu zawodowym ${ }^{21}$.

Cywilnoprawna ochrona czci obejmuje sfery:

- ochrony praw niemajątkowych - poprzez wyrażony w art. $24 \S 1$ kc nakaz,,zaniechania

działania, chyba że jest działaniem prawnym, np. uzasadniona krytyka";

- majątkową - naprawienie szkody, oparte na zasadzie z art. $24 \S 2 \mathrm{kc}$;

- pośrednią - poprzez zadośćuczynienie pieniężne ${ }^{22}$.

Prawa niemajątkowe są trudno definiowalne. Określa się je jako: ,indywidualne wartości świata uczuć, stanu psychicznego człowieka”. Cywilnoprawna ochrona dóbr osobistych znacznie przy tym rozszerza zakres odpowiedzialności w stosunku do zakresu prawa karnego, gdzie kluczowym punktem jest wykazanie winy umyślnej (przy przestępstwie $\mathrm{z}$ art. $212 \mathrm{kk}$ nie ma zastosowania wina nieumyślna). W sferze cywilnoprawnej decydująca jest bezprawność, definiowana jako, zachowanie sprzeczne z normami prawa lub zasadami współżycia społecznego bez względu na winę, a nawet świadomość sprawcy"23. Powód cywilny nie musi być obciążony ciężarem udowodnienia faktów odnośnie do bezprawności (a również winy). Wystarczy udowodnienie samego stwierdzenia faktu naruszenia dóbr osobistych $^{24}$.

Ograniczeniem odpowiedzialności cywilnoprawnej z zakresu ochrony dóbr osobistych jest „dozwolona krytyka”. Sąd Najwyższy w orzeczeniu z 19 września 1968 r. Sygn. II CR 291/68 określił granice dozwolonej krytyki: „krytyka jest działaniem społecznie pożytecznym i pożądanym, jeśli została podjęta w interesie społecznym, a nie w celu dokuczenia osobie. Krytyka nie powinna przekraczać granic potrzebnych dla osiągnięcia celów krytyki" ${ }^{25}$.

Godzi się dodać, że w szeregu przepisach prawnych o charakterze lex specialis zakres ochrony cywilnoprawnej dóbr osobistych został rozszerzony. W grę wchodzą przykładowo

${ }^{20}$ Tamże, s. 654-656.

${ }^{21}$ G. Artymiak, Rozłożenie ciężaru dowodu w sprawach o zniesławienie, „Palestra” 1995, nr 3-4, s. $62-63$.

${ }^{22}$ L. Gardocki, Zniestawienie..., dz. cyt., s. 55 i nast.

23 A. Wolter, Prawo cywilne. Zarys części ogólnej, PWN, Warszawa 1963, s. 180.

24 Tamże, s. 181.

${ }^{25}$ Tamże, s. 181-185. 
przepisy ustaw: prawo prasowe, prawo autorskie, wynalazcze itp. przewidujące szczególne formy zadośćuczynienia, na przykład prawo do żądania sprostowania, prawo do repliki (prawo prasowe) czy nadzwyczajne wynagrodzenie oraz zwrot korzyści (prawo autorskie) ${ }^{26}$.

Pokrzywdzeni mogą zatem dochodzić swoich roszczeń i w sferze prawnokarnej, i w sferze cywilnej, nic także nie stoi na przeszkodzie skorzystania z obu tych dróg, nawet w jednym postępowaniu, przy wykorzystaniu powództwa adhezyjnego (rozpoznawania w procesie karnym również odpowiedzialności cywilnoprawnej na wniosek - pozew - strony).

To ostatnie jednak napotyka niemałą przeszkodę proceduralną. Przestępstwa z art. 212 z urzędu należą do właściwości sądów rejonowych jako pierwszej instancji. Sprawy cywilne z zakresu ochrony dóbr osobistych z urzędu należą do właściwości sądów okręgowych pierwszej instancji (art. 17 kpc). By taka możliwość zaistniała, musiałoby nastąpić przejęcie sprawy z art. 212 przez sąd okręgowy jako pierwszej instancji, co zdarzyło się zresztą w głośnym procesie Andrzeja Leppera (a wyrok nakładał pieniężne zadośćuczynienie na rzecz jednego z pokrzywdzonych).

$\mathrm{Z}$ tych przyczyn procesy cywilne rozpoznawane są w oderwaniu od procesów karnych; nierzadka jest nawet praktyka, że rozstrzygnięcie cywilnoprawne następuje przed rozstrzygnięciem prawnokarnym. Nic zarazem nie stoi na przeszkodzie, by powództwo adhezyjne było wytaczane przy wykorzystaniu innych przepisów prawa cywilnego, chociażby podstawowego deliktu z art. $415 \mathrm{kc}$.

Nie ulega wątpliwości, że prawo cywilne daje znacznie szersze możliwości zarówno „odpłaty” wobec sprawcy, jak i możliwości naprawienia szkody materialnej i niematerialnej (jeżeli powstała). Oczywiście droga cywilnoprawna jest dłuższa, na pewno kosztowniejsza (co w końcu i tak nie ma znaczenia wobec zasady, że płaci przegrywający). Prawdą jest jednak też, że niektóre wyroki, na przykład nakazujące ,złożenie odpowiedniego oświadczenia", są trudne do wyegzekwowania, co pokazuje praktyka ostatnich lat i prawomocnie osądzonych spraw. Aż strach napisać, które z osób publicznych nie wykonały prawomocnych wyroków sądów.

W ostatnim czasie obserwuje się jednak zasadniczą różnicę w praktyce dochodzenia swych roszczeń w postępowaniach sądowych dotyczących zarówno pomówień (karnych), jak i deliktu naruszeń praw osobistych (cywilnych) na korzyść instytucji prawa cywilnego.

Liczba procesów karnych z art. 212 kk zaczęła gwałtownie spadać. Pojawiać się natomiast zaczęło coraz więcej procesów cywilnych z art. $23 \mathrm{kc}$. Sytuacja ta zdaje się potwierdzać tezę, że prawo cywilne zawiera więcej możliwości dochodzenia swych praw niż prawo karne. Dodatkowym ,elementem sprawczym” jest aktualny „maraton kampanii wyborczych", którego szczególne przepisy ordynacji wyborczej znacznie ułatwiają postępowania sądowe - w trybie ,wyborczym”.

Niekwestionowany jest także wpływ orzecznictwa Europejskiego Trybunału Praw Człowieka w Strasburgu, osobliwie w sferze polityki. Orzecznictwo ETPC jest wręcz bezlitosne dla czynnych polityków, wręcz nakładając na nich obowiązek posiadania w zakresie ochrony prawnej ,skóry nosorożca”. Przykładów jest mnóstwo:

${ }^{26}$ F. Błahut (red.), Kodeks cywilny. Komentarz, Wydawnictwo Prawnicze, Warszawa 1972, s. 90. 


\section{Peter Lingens kontra Austria (wyrok 8 sierpnia 1986 roku)}

Perła wśród orzeczeń.

W październiku 1975 roku w austriackiej telewizji ukazał się wywiad z Simonem Wiesenthalem - niestrudzonym poszukiwaczem nazistowskich zbrodniarzy wojennych. W trakcie wywiadu Wiesenthal wspomniał, że ówczesny przewodniczący Partii Liberalnej Friedrich Peter w czasie wojny był członkiem elitarnej jednostki SS, ,wsławionej” licznymi zbrodniami na okupowanym terenie ZSRR. W dniu następnym TV zadała na ten temat kilka pytań kanclerzowi Austrii Brunonowi Kreisky’emu, który wystąpił z obroną Petera (było po wyborach parlamentarnych, wyniki nie były jeszcze znane, w grę wchodziła ewentualność zawiązania koalicji rządzącej).

Wówczas Lingens, wybitny publicysta pisma „Profil”, w kilku kolejnych tekstach ostro zaatakował Kreisky’ego za „obronę byłych nazistów”. Kreisky natychmiast oskarżył Lingensa z art. 111 austriackiego kk (za zniesławienie), występując prywatnie z dwoma aktami oskarżenia. Proces trwał wiele lat w kilku sądach. Ostatecznie Lingens został uznany winnym pomówienia i skazany na 15 tys. szylingów grzywny. Za pomówienie uznano wyimki z tekstów Lingensa w postaci zdań: „minimalny wymóg moralności politycznej” i ,najbardziej nikczemny oportunizm”. Sprawa z wniosku skazanego trafiła do Strasburga. Trybunał orzekł o naruszeniu art. 10 Konwencji, tworząc zarazem w uzasadnieniu zasadę: granice dopuszczalnej krytyki są szersze w stosunku do polityka niż osoby prywatnej. Politycy każde swoje słowo i działanie wystawiają na kontrolę dziennikarzy i opinii publicznej. Dyskusja polityczna tkwi w samym centrum konstrukcji demokratycznego społeczeństwa ${ }^{27}$. 2. Feldek kontra Słowacja (wyrok 12 lipca 2001 roku)

Feldek, poeta i publicysta kulturalny, opublikował wiersz, w którym „,między wierszami” zarzucał ministrowi kultury Slobodnikowi faszystowską (faktycznie) przeszłość z czasów rządów ks. Tiso. Oskarżony i skazany za pomówienie wniósł sprawę do Strasburga. Trybunał, uznając naruszenie art. 10 Konwencji, w uzasadnieniu jeszcze raz dokładnie powtórzył zasadę określoną w wyroku w sprawie Lingensa, niejako dodatkowo ją wzmacniając ${ }^{28}$.

3. Gerhard Oberschlick kontra Austria (wyrok 1 lipca 1997 roku)

Oberschlick, publicysta i wydawca wiedeńskiego pisma „Forum”, oburzony „występami” z pogranicza faszyzmu i nacjonalizmu przewodniczącego Partii Ludowej Jörga Haidera w opublikowanym w „Forum” tekście nazwał go wprost ...idiotą! Postawiony przed sądem za zniesławienie został skazany na tysiąc szylingów grzywny oraz konfiskatę inkryminowanego numeru pisma. Austriaccy sędziowie orzekli, że idiota jest inwektywą ad personam, więc przekracza granice swobody wypowiedzi.

Trybunał, orzekając o naruszeniu art. 10 Konwencji, w uzasadnieniu zasygnalizował kolejną zasadę: politycy prowokujący swoimi wypowiedziami czy zachowaniem opinię publiczną muszą się liczyć nawet z gwałtownymi reakcjami ${ }^{29}$.

Warto wspomnieć, ze Oberschlick jest rekordzistą, wielokrotnym ,recydywistą” Trybunału Strasburskiego. Wygrał przeciwko Austrii trzy kolejne procesy o naruszenie wolności słowa; ten z ,idiotą” był trzeci. Skądinąd Austria pod wpływem wyroków ETPC dokonała

\footnotetext{
27 Tamże, s. 94.

28 Tamże, s. 94.

29 Tamże, s. 94.
} 
istotnych zmian w prawie karnym materialnym (i procesowym), łagodząc znacznie karalność naruszenia wolności słowa.

Przytoczone tu kazusy w jakiś sposób dokonują swoistego wartościowania granic ochrony różnych osób. Nazwanie polityka idiotą jest dopuszczalne, a nawet pożyteczne, ale już określenie ćwok w stosunku do strażnika czy policjanta stanowi naruszenie wolności słowa. Na najlepszą ochronę liczyć mogą jedynie osoby prywatne. Zasady te zostały przywołane w dziesiątkach wyroków Trybunału.

4. Miguel Castells kontra Hiszpania (wyrok 23 kwietnia 1992 roku)

W 1979 roku Miguel Castells, adwokat, publicysta, a w tym czasie senator Hiszpanii, opublikował bardzo ostry tekst (uzupełniony następnie kilkoma wystąpieniami publicznymi), w którym zarzucał władzom Hiszpanii całkowity brak działań w kierunku wykrycia sprawców kilku zabójstw działaczy baskijskich (wręcz tuszowanie niewątpliwych zbrodni). Władze Hiszpanii zareagowały bardzo zdecydowanie - Castells (mimo immunitetu) został postawiony przed sądem i surowo ukarany za zniesławienie. „Obejście” immunitetu uzasadniono tym, iż krytyczne wystąpienia zostały dokonane $\mathrm{w}$ prasie oraz poza parlamentem.

Trybunał orzekł o naruszeniu art. 10 Konwencji ${ }^{30}$.

W uzasadnieniu stworzył kolejny standard wolności słowa w debacie politycznej: Zasadą naczelną jest swoboda debaty politycznej, szczególnie ostro określana w stosunku do opozycji. Nie ma znaczenia, czy ostre słowa padły w debacie parlamentarnej czy poza nią. Rządzący powinni ograniczyć korzystanie ze środków prawnych, przede wszystkim karnych, gdy mają do dyspozycji inne sposoby odpowiedzi na ostrą krytykę bądź nieuzasadnione zarzuty ${ }^{31}$.

5. Ważne uzupełnienie tej tezy można znaleźć w uzasadnieniu kazusu Hanysick kontra Wielka Brytania z 7 grudnia 1976 roku.

Trybunał orzekł wówczas, że: wolność wypowiedzi musi dotyczyć nie tylko informacji i idei traktowanych nieagresywnie i obojętnie, ale również wypowiedzi, które urażają, szokują lub niepokoją 32 .

Kolejny istotny problem Trybunał dostrzegł w poniższym kazusie.

6. Thorgeir Thorgeirson kontra Islandia (wyrok 25 czerwca 1992 roku)

W 1983 roku pisarz T. Thorgeirson na podstawie plotek (vox populi) opublikował niezwykle ostry artykuł piętnujący brutalność policji (wcześniej zdarzył się potwierdzony - i ukarany - fakt pobicia zatrzymanego). Z tekstu wiało grozą: „,bestie w mundurach”, „nocne szwadrony”, ,brutale i sadyści”, „nocna dżungla”. Z inicjatywy związku zawodowego policjantów Thorgeirsonowi wytoczono proces (o znieważenie nieokreślonej liczby policjantów), w wyniku którego został skazany na 10 tys. koron grzywny z zamianą na 3 miesiące aresztu.

Trybunał orzekł o naruszeniu art. 10 Konwencji, między innymi zwracając uwagę, że nawet niepotwierdzone informacje, jeśli stanowią zagadnienie nośne społecznie, zasługują na publikację. Dodatkowo sformułowano uwagę o: zjawisku zwanym chilling effect, efekcie

\footnotetext{
30 Tamże, s. 99 .

31 I.C. Kamiński, Swoboda wypowiedzi w orzecznictwie Europejskiego Trybunału Praw Człowieka w Strasburgu, Zakamycze, Kraków 2002, s. 38 i nast.

32 Tamże, s. 173.
} 
schładzającym - obawie dziennikarza, publicysty, polityka (pod wpływem skazania własnego lub innych osób) przed podejmowaniem aktywniejszych działań33.

Jest to ten sam efekt, przed którym przestrzegał jeszcze w 1929 roku profesor Władysław Wolter na kanwie sprawy profesora Kulczyńskiego. Bardzo dobitnie zwracała na to uwagę profesor Ewa Łętowska w sprawie P 10/06 Trybunału Konstytucyjnego.

Politycy występują w sprawach o pomówienie i znieważenie bardzo często. Częstokroć po obu stronach barykady, to znaczy i jako oskarżeni, i jako oskarżyciele. Wiele procesów miesza się ze sprawami dziennikarskimi. Zdarzają się sprawy bardzo poważne, sięgające kwintesencji polityki polskiej, wiele przybiera postać groteski, czy... kabaretu.

Spory sądowe stają się powoli „stałym elementem gry” politycznej. Duża liczba spraw „politycznych" znajduje finał w sądach cywilnych, o naruszenie dóbr osobistych. Trudno zliczyć, ile takich spraw ma na koncie działacz PIS-u Jacek Kurski. Od lat toczą się zażarte spory i procesy byłego prezydenta Lecha Wałęsy, a kultura życia politycznego, debaty politycznej, stacza się coraz niżej. Oto przykłady z ostatnich lat:

Lech Kaczyński kontra Mieczysław Wachowski

W listopadzie 2005 roku w trakcie końcowej fazy kampanii prezydenckiej sąd ogłosił wyrok skazujący Lecha Kaczyńskiego za zniesławienie Mieczysława Wachowskiego poprzez nazwanie go „,wielokrotnym przestępcą”. Panowie poróżnili się jeszcze w czasie wspólnej pracy w kancelarii prezydenta Wałęsy, a spór polityczny czy służbowy przerodził się na lata w zapiekłą nienawiść. Kaczyński, jeszcze gdy pełnił funkcję ministra sprawiedliwości w jednym z materiałów telewizyjnych użył wobec Wachowskiego słów, jak wyżej przytoczone. Wachowski wytoczył Kaczyńskiemu proces cywilny i drugi, karny. Proces cywilny wygrał, a sąd zobowiązał pozwanego między innymi do przeproszenia powoda, czego Lech Kaczyński nie uczynił. Proces karny toczył się z przerwami, dłużej niż cywilny. Wyrok nie jest prawomocny i prawomocny już nigdy nie będzie.

Andrzej Lepper kontra lewica

W czasie przemówienia w Sejmie Andrzej Lepper użył w stosunku do grupy posłów lewicy serii zjadliwych pomówień, nadając im charakter pytań „Ile pan wziął łapówki?”. $\mathrm{W}$ tej sprawie postępowanie było nietypowe - prokuratura objęła je ściganiem z urzędu. Lepper został skazany na wysoką karę 15 miesięcy pozbawienia wolności w zawieszeniu, wysoką grzywnę, nawiązkę oraz wysoką nawiązkę na rzecz jednego z pokrzywdzonych. Wyrok uprawomocnił się po wyroku sądu drugiej instancji. Wyrok zapadł w dniu, w którym Andrzej Lepper odbierał $\mathrm{z}$ rąk prezydenta nominacje na wicepremiera i ministra rolnictwa (sic!). Jakby jednak nie patrzeć na osobę oskarżonego i jego drogę polityczną, paralele do kazusu Castells kontra Hiszpania są bardzo widoczne.

Sobecka ściga Ziomeckiego

20 lutego 2006 roku „Super Express” na pierwszej kolumnie zamieścił sensacyjny tytuł Babsztyl tże bez wstydu. Chodziło o relację z ,przepychanek" w sprawie kandydującej na funkcję rzecznika praw dziecka posłanki LPR Anny Sobeckiej, która w jednej z wypowiedzi minęła się z prawdą. Sobecka natychmiast zawiadomiła prokuraturę o „,żeniu funkcjonariusza publicznego". Prokuratura wszczęła postępowanie i przedstawiła redaktorowi naczelne-

\footnotetext{
${ }^{33}$ Tamże, s. 111.
} 
mu „Super Expressu” Mariuszowi Ziomeckiemu zarzut przestępstwa z art. 226 kk. W sprawie od razu zareagował rzecznik praw obywatelskich, w ostrym wystąpieniu zwracając uwagę warszawskiej prokuraturze na nadużywanie kodeksu karnego w sporze z dziennikarzami. Zdaniem rzecznika ,prokuratura powinna zachować większą powściągliwość” w takich sprawach jako godzących w wolność prasy. Sprawa grozi eskalacją. Jeszcze nie wiadomo, jakich retorsji prawnych może zażądać (już nie posłanka, ale nadal rzecznik praw dziecka) wobec „The Washington Post”, który w konkursie na „Idiotę Roku” zapewnił jej trzecie miejsce za wykrycie „układu” gejowskiej jaczejki wśród teletubisiów. Prokuratura mogłaby zakwalifikować to jako poniżenie w opinii publicznej (tylko trzecie miejsce?!).

Rokita kontra Wieczerzak

W czasie debaty nad exposé premiera Jerzego Buzka w maju 2004 roku Andrzej Lepper zarzucił posłowi PO Janowi Marii Rokicie, że ,robił interesy z byłym prezesem PZU Życie Grzegorzem Wieczerzakiem (podejrzanym w aferze PZU Życie). Ripostując, Rokita oburzył się na „potwarz” Leppera posądzającego go o „kryminalne związki z bardzo znanym przestępcą”. Wieczerzak skierował prywatny akt oskarżenia o zniesławienie. Wyrokiem z 13 lipca 2007 roku warszawski sąd rejonowy uznał znanego polityka winnym, skazując go na 5 tys. zł grzywny. Wieczerzak dowodził, że nie jest przestępcą, skoro nie został skazany (jego aferalną sprawę sąd zwrócił prokuraturze do uzupełnienia jeszcze w 2004 roku).

W ostatnich już nie latach, ale miesiącach nastąpiła prawdziwa eksplozja spraw o naruszenie dóbr osobistych pomiędzy osobami publicznymi. Aż trzy powództwa wpłynęły ze strony posłanki Krystyny Pawłowicz przeciwko Jerzemu Owsiakowi.

Jurek Owsiak poinformował o tym na swoim internetowym profilu. Pierwsza sprawa dotyczy słów, które Jurek Owsiak wypowiedział w czasie Przystanku Woodstock 2017. Skierował wówczas do Krystyny Pawłowicz między innymi takie zdania: „Niech pani spróbuje seksu. Poczuje pani motyle w brzuchu, poczuje pani rozluźnione plecy. Poczuje pani kwiat we włosach, a przez to w głowie też się może poukładać”. Drugi pozew dotyczy sprawy wokalisty U2 Bono. Swój początek ma w kwietniu 2016 roku, kiedy to Pawłowicz napisała na Facebooku, że ,pewien pieśniarz, niejaki Bono, odstawił na chwilę instrument muzyczny i niestety przemówił. Powiedział tylko to, co wiedział, czyli niewiele. A dowiedział się od europejskich lewaków, że Polska i Węgry są hiper nacjonalistyczne”. Odpowiedź Jurka Owsiaka brzmiała następująco: „Na ścianie mojego gabinetu w Fundacji wisi jej wypowiedź o Bono sprzed kilku miesięcy. Jest to coś, co dodaje mi siły, abyśmy robili to, co robimy. Na przykład Najpiękniejszy Festiwal Świata - Przystanek Woodstock". W trzeciej sprawie chodzi o fanpage, który działa na Facebooku. Nosi on nazwę Ruch wysłania Krystyny Pawłowicz w kosmos. Owsiak nie jest jednak ani jego założycielem, ani administratorem. Jurek Owsiak potwierdza, że będzie obecny na rozprawach. Przyznaje, że jest ciekawy, jak będą one wyglądały. Owsiak wypowiedzi Krystyny Pawłowicz nazwał „huraganem nienawistnej mowy skierowanej do Polaków".

W przypadku pierwszej sprawy Jerzy Owsiak musi przeprosić Krystynę Pawłowicz za swoje wypowiedzi i organizację konkursu na rozszerzenie skrótu RWKPWK. Wyrok nie jest prawomocny. Sąd odrzucił natomiast żądanie zadośćuczynienia w wysokości 50 tys. zł, którego domagała się Pawłowicz. 
Przeprosiny posłanki muszą pojawić się na stronie Kreciola.tv w ciągu siedmiu dni od uprawomocnienia się wyroku i mają być tam wyświetlane.

Krystyna Pawłowicz na Twitterze przypomniała, że w przyszłym roku rozpoczną się dwie sprawy karne, które wytoczyła pomysłodawcy WOŚP z prywatnego aktu oskarżenia. Chodzi m.in. o słowa Owsiaka z Przystanku Woodstock, gdy mówił o Pawłowicz: „Niech pani spróbuje seksu. Poczuje panie motyle w brzuchu, rozluźnione plecy”. Jerzy Owsiak zapowiedział apelację ${ }^{34}$.

Kolejnym bohaterem postępowań sądowych okazał się premier RP Mateusz Morawiecki. Dotychczas przegrał dwie sprawy.

Sąd Apelacyjny zdecydował, że Mateusz Morawiecki będzie musiał sprostować swoją wypowiedź, która padła podczas spotkania z mieszkańcami województwa lubuskiego. Premier powiedział wówczas, że za rządów PO ,nie było ani dróg, ani mostów”. Sędzia Sądu Apelacyjnego Paulina Asłanowicz poinformowała, że sąd postanowił zobowiązać Morawieckiego do opublikowania w ciągu 48 godzin na antenie telewizji TVP Info i TVN przed głównymi wydaniami programów Wiadomości i Fakty - po blokach reklamowych bezpośrednio poprzedzających emisję wyżej wymienionych programów oświadczenia poprzez jego odczytanie oraz jednoczesne wyświetlenie planszy z tekstem wypełniającym cały ekran.

Treść tego oświadczenia ma brzmieć: „Nieprawdziwe są informacje podane przeze mnie w dniu 15 września 2018 roku podczas wiecu wyborczego komitetu wyborczego Prawo i Sprawiedliwość w Świebodzinie, że w ciągu jednego do półtora roku wydawana jest przez nas większa suma na drogi lokalne niż za czasów koalicji PO i PSL w ciągu ośmiu lat. Mateusz Morawiecki, premier rządu Rzeczpospolitej Polskiej”. Jak uzasadniała sędzia Asłanowicz, Sąd Apelacyjny uznał, że kluczowa w tej sprawie jest kwestia tego, czy stwierdzenia, jakie padły z ust premiera, miały charakter oceny, czy też była to informacja poddająca się weryfikacji w kategoriach prawdy i fałszu. Sąd Apelacyjny doszedł do przekonania, że pierwsza część tej wypowiedzi, dotycząca tego, że nie było dróg i mostów, ma charakter retoryczny, takiej hiperboli, (ale) należy ją czytać w połączeniu z drugą częścią tej wypowiedzi, w której zawarte zostało stwierdzenie, że ,przez osiem lat wydali 5 mld zł na drogi lokalne, tj. tyle, ile my wydajemy w ciągu jednego roku, do półtora roku”. W ocenie Sądu Apelacyjnego należało zgodzić się ze skarżącymi, że ta druga część wypowiedzi poddaje się tej weryfikacji i Sąd Apelacyjny badał jej prawdziwość. Sąd doszedł do przekonania, że w świetle dokumentów złożonych do akt sprawy ta wypowiedź jest nieprawdziwa, stąd zastosował środek przewidziany w art. 111 Kodeksu wyborczego - oświadczyła Asłanowicz. Od postanowienia Sądu Apelacyjnego nie przysługuje skarga kasacyjna i podlega ono natychmiastowemu wykonaniu.

14 października 2018 roku podczas konwencji PiS w Krakowie szef rządu mówił, że walka o czyste powietrze będzie dużo szybsza, jeśli wybory w tym mieście wygra Małgorzata Wassermann. Morawiecki stwierdził że ,poprzednicy, w tym ci, którzy rządzili tym miastem, nie zrobili nic lub prawie nic" w walce ze smogiem. To właśnie za tę wypowiedź

${ }^{34}$ Owsiak przegrał z Pawłowicz. Sąd nakazat szefowi WOŚP przeprosić. W przyszłym roku kolejne sprawy, http://wiadomosci.gazeta.pl/wiadomosci/7,114883,24226310,owsiak-przegral-z-pawlowiczsad-nakazal-szefowi-wosp-przeprosic.html [dostęp: 25.03.2019]. 
prawnicy prezydenta Krakowa przygotowali pozew w trybie wyborczym przeciwko premierowi. W pierwszej instancji sąd uznał, że wypowiedź Morawieckiego jest oceną, a nie stwierdzeniem faktu. Majchrowski odwołał się od tego postanowienia, a sąd wyższej instancji przyznał mu rację.

„Nieprawdziwe są informacje podane przeze mnie w dniu 14 października 2018 roku podczas spotkania wyborczego komitetu wyborczego Prawo i Sprawiedliwość w Krakowie o braku działań prezydenta miasta Krakowa Jacka Majchrowskiego na rzecz poprawy jakości powietrza w Krakowie" - brzmi sprostowanie premiera, które ukazało się między innymi w krakowskim dodatku „Gazety Wyborczej”.

Sąd Apelacyjny zdecydował też, że Morawiecki musi zamieścić sprostowanie także w TVP Info oraz Polsat News przed głównymi wydaniami programów informacyjnych tych stacji, czyli Wiadomościami i Wydarzeniami, oraz na profilu PiS na Facebooku ${ }^{35}$.

Nie trzeba być politykiem z ,pierwszych stron gazet” i centralnego szczebla.

Przekonał się o tym również burmistrz Wadowic:

W mieście papieża-Polaka prawicowa artystka Elżbieta Ł. pobiła lewicowego burmistrza Mateusza Klinowskiego. Napastniczka trafiła do aresztu, gdzie odwiedziła ją była burmistrz i posłanka PiS. „To był grad «plaskaczy» i osłaniający się burmistrz [...]”-skomentował sprawę na jednym z portali miejscowy bloger, świadek zdarzenia.

Było tak: 12 grudnia przed południem specjalistka od scrapbookingu (sztuki dekorowania albumów ze zdjęciami) Elżbieta $Ł$. weszła do Urzędu Miasta w Wadowicach i zaczęła wszystko nagrywać. Nie po raz pierwszy, bo Ł. wielokrotnie wcześniej udawała dziennikarkę, dokumentującą pracę urzędników. Regularnie pojawiała się także na sesjach Rady Miejskiej z tekturkami, na których wcześniej wypisała hasła: Odwołajmy Klinowskiego, Klinowski nas okrada albo Wadowice padty tupem złodzieja. Chciała także zorganizować referendum w sprawie odwołania burmistrza z funkcji. Referendum, do którego nie doszło, poparła między innymi Ewa Filipiak, była burmistrz Wadowic, a obecnie posłanka Prawa i Sprawiedliwości, zaprzyjaźniona z premier Beatą Szydło. Klinowski to burmistrz, jak na święte miasteczko, szczególny: doktor prawa, ateista i zwolennik legalizacji marihuany. Pani Ł. od dłuższego czasu wywoływała awantury w Urzędzie Miejskim, utrudniała pracę urzędnikom i radnym, posuwała się nawet do gróźb, już wcześniej była agresywna - twierdzi Klinowski. Wreszcie miarka się przebrała. - Uniemożliwiała mi pracę, nie reagowała na moje prośby. A gdy zasłoniłem się przed aparatem, którym świeciła mi w oczy, kilkakrotnie uderzyła mnie w twarz - relacjonował burmistrz. Następnie Klinowski wezwał policję. Ta przybyła po prawie 30 minutach. Kobietę wyprowadzono w kajdankach. Na komisariacie dostała zarzut naruszenia nietykalności cielesnej funkcjonariusza publicznego. Grożą za to trzy lata więzienia. Co ciekawe, w krakowskim sądzie leży już złożony wcześniej przez Klinowskiego prywatny akt oskarżenia przeciw Ł. Klinowski zarzuca jej zniesławienie. Po prawie rocznym postępowaniu przed sądem w Wadowicach zapadł wyrok - Sąd uznał winę kobiety i wymierzył karę grzywny (250 stawek) oraz wypłatę zadośćuczynienia za doznaną krzywdę pokrzywdzonym, czyli burmistrzowi i jego asystentce (w sumie około 4 tys. zł). Kobieta musi też pokryć koszty zastępstwa procesowego na rzecz adwokata burmistrza i jego asystentki ${ }^{36}$.

${ }^{35}$ Joanna Kopcińska po wyroku ws. słów Morawieckiego: będzie stosowne sprostowanie, ale premier nie musi przepraszać opozycji, https://wiadomosci.onet.pl/kraj/wyrok-ws-slow-mateusza-morawieckiego -o-drogach-bedzie-sprostowanie/5lw2c8c [dostęp: 25.03.2019].

36 A. Szulc, Kto chce dorwać burmistrza Wadowic?, Newsweek.pl, 19.12.2016, https://www.newsweek.pl/polska/ludzie/atak-na-mateusza-klinowskiego-burmistrza-wadowic-elzbieta-1/17reefk [dostęp: 19.02.2019]. 


\section{Proces Kaczyński vs Wałęsa przed Sądem Okręgowym w Gdańsku}

Proces o ochronę dóbr osobistych z powództwa Jarosława Kaczyńskiego przeciwko Lechowi Wałęsie rozpoczął się w marcu przed Sądem Okręgowym w Gdańsku.

Kaczyński domaga się od Wałęsy przeprosin i wpłaty 30 tys. zł na cele społeczne za wpisy na Facebooku od czerwca do września 2016 roku. W pozwie stwierdzono, że ze strony byłego prezydenta padły zarzuty, iż „Jarosław Kaczyński podczas lotu samolotu z polską delegacją do Smoleńska, mając świadomość nieodpowiednich warunków pogodowych, kierując się brawurą, wydał polecenie, nakazał lądowanie, czym doprowadził do katastrofy lotniczej w dniu 10 kwietnia 2010 roku". W oświadczeniu, którego domaga się od Wałęsy Kaczyński, ma znaleźć się stwierdzenie, że były to „bezprawne i nieprawdziwe zarzuty".

Kaczyński domaga się też przeprosin za słowa Wałęsy o tym, że „nie jest zdrowy, zrównoważony psychicznie". Prezes PiS chce ponadto, by były prezydent przeprosił go za zarzuty wydania polecenia „wrobienia” go, przypisania mu współpracy z organami bezpieczeństwa PRL.

$[\ldots]$

Prezes PiS mówił, że odbiera tę wypowiedź jako naruszającą jego dobra osobiste, ponieważ ,jest ona całkowicie nieprawdziwa” i wskazuje, że jest on „człowiekiem wyjątkowo złej woli i skrajnie nieuczciwym”. Kaczyński mówił też, że w jego otoczeniu politycznym głównie śmiano się z tej tezy, bo jest ona „absurdalna”, natomiast uznano ją za obraźliwą.

Podczas rozprawy sędzia przytoczyła wypowiedź Kaczyńskiego w sejmie z lipca ubiegłego roku, podczas drugiego czytania projektu nowej ustawy o Sądzie Najwyższym: „Wiem, że boicie się prawdy, ale nie wycierajcie swoich mord zdradzieckich nazwiskiem mojego śp. brata, niszczyliście go, zamordowaliście go, jesteście kanaliami”.

Sędzia pytała prezesa PiS, jak ocenia w kontekście temperatury debaty publicznej i wypowiedzi pozwanego tego rodzaju swoją wypowiedź.

- To była wypowiedź spowodowana [...] sytuacją, która nie miała nic wspólnego $\mathrm{z}$ tą, która jest przedmiotem postępowania. To była moja reakcja na kolejne - już w dziesiątkach razy - obrażanie mojego brata, przytaczanie jego wypowiedzi w ten sposób. Czyli krótko mówiąc: był to pewien wybuch emocji. A tutaj nie ma żadnych powodów, żeby pozwany miał w związku z tymi sprawami jakieś emocje. Więc nie można tych wypowiedzi ze sobą porównywać - wyjaśnił Kaczyński.

Pełnomocnik Wałęsy pytał Kaczyńskiego, czy w debacie publicznej, która się toczy pomiędzy nim a Wałęsą od wielu lat, temperatura dyskusji nie powoduje, że czasami „dochodzi do pewnych ocen" i że te oceny są także przez niego dokonywane.

Kaczyński odpowiedział, że „ta dyskusja ma charakter jednostronny”.

- Nie widzę powodów, by odpowiadać panu pozwanemu na jego zaczepki ze względów, których nie będę tu bliżej przytaczał. Nie ma dyskusji, to ciąg zaczepek, dyskusje prowadzę z innymi osobami - powiedział.

Pytany przez pełnomocnika Wałęsy, czy nie było z jego strony zaczepek w stronę Wałęsy i czy uważa, że być może i jemu zdarzyło się naruszyć dobra osobiste byłego prezydenta, Kaczyński odpowiedział: „Nie uważam, żebym naruszał dobra osobiste (Wałęsy)".

- W ogromnej większości w ogóle się nie wypowiadałem. A jeśli coś mówiłem, to były to odpowiedzi na różnego rodzaju ataki ze strony Lecha Wałęsy. Natomiast krytykowałem go politycznie w okresie, w którym uważałem, że ta krytyka czy nawet ostrzejsze przedsięwzięcie, było potrzebne ze względu na zagrożenie polskiej demokracji. I uważam po dziś dzień, że to było po pierwsze słuszne, a po drugie, jak 
wiem z różnego rodzaju materiałów służb, do których miałem dostęp, skuteczne. Tzn.

doprowadziły do upadku Lecha Wałęsy - powiedział Kaczyński ${ }^{37}$.

Proces trwa, bardzo wiele wzajemnych oskarżeń już na sali sądowej padło i zdecydowanie żaden z polityków nawet nie zamierza myśleć o zawarciu ugody. Trzeba też zwrócić uwagę na fakt, że wkraczamy w rok wyborczy, jednakowo trudny dla wszystkich ugrupowań biorących udział w wyborach. Mam przeczucie, graniczące z pewnością, że do sądów ruszy lawina prywatnych aktów oskarżenia czy procesów w trybie wyborczym.

\section{Bibliografia}

Artymiak G., Rozłożenie ciężaru dowodu w sprawach o zniesławienie, „Palestra” 1995, nr 3-4. Bafia J., Mioduski K., Siewierski M., Kodeks karny, komentarz, Wydawnictwo Prawnicze, Warszawa 1977.

Błahut F. (red.), Kodeks cywilny. Komentarz, Wydawnictwo Prawnicze, Warszawa 1972.

Gardocki L., Prawo karne, Wydawnictwo C.H. Beck, Warszawa 1998.

Gardocki L., Zniesławienie, „Palestra” 1994, nr 3-4.

Górniak O. (red.), Kodeks karny, komentarz, LexisNexis, Warszawa 2004.

Kamiński I.C., Swoboda wypowiedzi w orzecznictwie Europejskiego Trybunału Praw Człowieka w Strasburgu, Zakamycze, Kraków 2002.

Kulesza W., Zniestawienie i zniewaga, Wydawnictwo Prawnicze, Warszawa 1984.

Wolter A., Prawo cywilne. Zarys części ogólnej, PWN, Warszawa 1963.

Zoll A. (red.), Kodeks karny, część szczególna, t. 2, Zakamycze, Kraków 1999.

\section{Źródla internetowe}

Akty prawne, Katedra Prawa Karnego Procesowego i Kryminalistyki, https://prawo.ug.edu. $\mathrm{pl} /$ wydzial/struktura wydzialu/katedry pracownie zaklady/katedra prawa karnego procesowego i kryminalistyki/zaklad kryminalistyki_i_prawa_dowodowego/akty prawne [dostęp: 19.02.2019].

Informacje na temat Polski i Europy, Wikipedia, http://www.coe.org.pl/ [dostęp: 12.02.2019].

Joanna Kopcińska po wyroku ws. słów Morawieckiego: będzie stosowne sprostowanie, ale premier nie musi przepraszać opozycji, https://wiadomosci.onet.pl/kraj/wyrok-ws-slow-mateusza-morawieckiego-o-drogach-bedzie-sprostowanie/5lw2c8c [dostęp: 25.03.2019].

Kaczyński przed sądem: nie wydawatem bratu żadnych poleceń $w$ trakcie lotu do Smoleńska, polsatnews.pl, 22.11.2018, http://www.polsatnews.pl/wiadomosc/2018-11-22/kaczynski-i -walesa-stawili-sie-na-rozprawie-o-ochrone-dobr-osobistych-powitaly-ich-okrzyki// [dostęp: 19.02.2019].

\footnotetext{
${ }^{37}$ Kaczyński przed sądem: nie wydawatem bratu żadnych poleceń $w$ trakcie lotu do Smoleńska, polsatnews.pl, 22.11.2018, http://www.polsatnews.pl/wiadomosc/2018-11-22/kaczynski-i-walesa -stawili-sie-na-rozprawie-o-ochrone-dobr-osobistych-powitaly-ich-okrzyki// [dostęp: 19.02.2019].
} 
Owsiak przegrał z Pawłowicz. Sąd nakazat szefowi WOŚP przeprosić. W przyszłym roku kolejne sprawy, http://wiadomosci.gazeta.pl/wiadomosci/7,114883,24226310,owsiak-przegral-z-pawlowicz-sad-nakazal-szefowi-wosp-przeprosic.html [dostęp: 25.03.2019].

Szulc A., Kto chce dorwać burmistrza Wadowic?, Newsweek.pl, 19.12.2016, https://www. newsweek.pl/polska/ludzie/atak-na-mateusza-klinowskiego-burmistrza-wadowic-elzbieta-1/ 17reefk [dostęp: 19.02.2019].

\section{Streszczenie}

\section{Pomówienie w polityce. Wybrane aspekty prawne i empiryczne}

Zjawisko pomówienia stało się w aktualnej polityce zarówno centralnego, jak i lokalnego szczebla niejako „stałym elementem gry”. Dyskusja na poziomie parlamentarnym (określana niegdyś pięknie jako język parlamentarny) przenosi się coraz częściej na sale rozpraw sądowych ku uciesze sprawozdających dziennikarzy i szerokiego społeczeństwa, żywo i z lubością obserwującego obrzucanie się błotem przez ludzi z pierwszych stron gazet. Warto zatem przyjrzeć się bliżej temu zjawisku, zdefiniować je i pokrótce omówić.

Słowa kluczowe: pomówienie, dobra osobiste, polityka, wybory, sąd, media, wyrok, sprostowanie

\section{Summary}

\section{Defamation in politics. Selected legal and empirical aspects}

The phenomenon of defamation has become a ,permanent element of the political game", at a central and local level. Debates at the parliamentary level (and what was once beautifully termed - parliamentary language) has once again moved to the courtroom. Journalists and society have been able to enjoy watching the mudslinging on the front pages of newspapers. It is worth taking a closer look at defamation, to define it and briefly discuss it.

Keywords: defamation, personal rights, politics, elections, court, media, judgement, justification 
Emilia Szczęsna (iD https://orcid.org/0000-0002-8159-5928

Akademia Humanistyczno-Ekonomiczna w Łodzi, Wydział Zamiejscowy w Sieradzu

\section{Unijne przepisy o ochronie danych osobowych w jednostkach samorządu terytorialnego}

\section{Wprowadzenie}

Zatrudnienie inspektora ochrony danych osobowych, pozyskiwanie zgody na przetwarzanie danych, obowiązkowe zgłaszanie naruszeń i powiadomienie podmiotu zainteresowanego, uściślenie obowiązków podmiotów przetwarzających dane oraz korzystanie ze zmienionych przepisów odnoszących się do międzynarodowego przekazywania danych osobowych to kilka nowych zasad, z którymi pół roku temu musiały się zmierzyć między innymi jednostki samorządu terytorialnego na mocy unijnego Rozporządzenia Parlamentu Europejskiego i Rady (UE) 2016/679 z dnia 27 kwietnia 2016 r. w sprawie ochrony osób fizycznych w związku z przetwarzaniem danych osobowych i w sprawie swobodnego przepływu takich danych oraz uchylenia dyrektywy 95/46/WE (RODO). Nowe regulacje dotknęły wszystkich dziedzin działalności jednostek samorządowych, dla których gromadzenie i przetwarzanie danych osobowych jest niezbędne do realizacji wyznaczonych celów i zadań. Najbardziej odczuwalne zmiany to te, które są związane z zaplanowaniem dodatkowych środków w budżecie, a do nich niewątpliwie należy instytucja inspektora ochrony danych osobowych (dalej: IODO). Liczba inspektorów w danej gminie jest uzależniona od liczby jednostek podlegających pod dany urząd, a jeden inspektor może być odpowiedzialny za nie więcej niż dziewięć podmiotów. Zatem im większa gmina, tym więcej instytucji oraz potrzeba większej liczby inspektorów i środków w budżecie. Z finansami jest również związana odpowiedzialność za nieprawidłowe przetwarzanie danych osobowych. Za naruszenie art. 25 RODO (zasada privacy by design oraz privacy by default) ${ }^{1}$, art. 29 (przetwarzanie

\footnotetext{
${ }^{1}$ Zarówno unijny, jak i polski ustawodawca nie wydał żadnego aktu, w którym istniałaby definicja zasady prywatności w fazie projektowania (ang. privacy by design) oraz zasady prywatności w ustawieniach
} 
z upoważnienia administratora lub podmiotu przetwarzającego), art. 30 (rejestr czynności przetwarzania), art. 31 (współpraca z organem nadzorczym) oraz za naruszenie postanowień art. 32 (bezpieczeństwo przetwarzania) grozi kara do $10 \mathrm{mln}$ euro, a w przypadku przedsiębiorstwa - kara w wysokości 2 procent jego całkowitego, rocznego światowego obrotu z poprzedniego roku obrotowego ${ }^{2}$. Natomiast za naruszenie zasad wynikających z art. 5, art. 7 (zgoda na przetwarzanie), art. 15 (prawo dostępu przysługującego osobie, której dane dotyczą) oraz art. 16 (prawo do sprostowania i usuwania danych) grozi kara w wysokości do $20 \mathrm{mln}$ euro, a w przypadku przedsiębiorstwa w wysokości 4 procent jego całkowitego, rocznego światowego obrotu z poprzedniego roku obrotowego ${ }^{3}$.

Generowaniem dodatkowych kosztów było również wprowadzenie do obiegu nowych formularzy mających swoje umocowanie w uchwałach, instrukcjach i regulaminach odpowiadających nowym przepisom o ochronie danych osobowych.

\section{ISO 27001 jako wsparcie dla samorządów w procesie wdrażania RODO}

Posiadanie certyfikatu międzynarodowej normy technicznej ISO z grupy 27001 dla wielu jednostek samorządu terytorialnego stało się bardzo pomocne podczas wdrażania nowych przepisów. Celem wskazanej procedury jest zagwarantowanie podstawowych zasad dotyczących zarządzania zbiorami zawierającymi dane osobowe oraz określenie reguł udostępniania danych osobowych. Jest to norma „określająca wymagania dla ustanowienia, wdrażania, zarządzania, monitorowania i przeglądu udokumentowanego systemu zarządzania bezpieczeństwem informacji w organizacji"4. ISO 27001 wymaga przeprowadzenia oceny ryzyka, co ma chronić przed ujawnieniem danych w jednostce organizacyjnej. Podobny obowiązek wynika z RODO z tą różnicą, że tutaj administrator musi ocenić skutki dla ochrony danych (ang. private impact assessment, PIA), zanim rozpocznie przetwarzanie. Kolejnym elementem wynikającym z normy technicznej i jednocześnie wspierającym procedurę wdrażania nowych przepisów jest zarządzanie incydentami bezpieczeństwa informacji. Na mocy art. 33 ust. 1 RODO nie później niż w terminie 72 godzin od stwierdzenia naruszenia administrator ma obowiązek powiadomić organ ochrony danych osobowych o incydencie skutkującym ryzykiem naruszenia praw i wolności danej osoby fizycznej. Analogiczny mechanizm jest narzucony w ramach ISO 27001. Jeżeli dana jednostka wdrożyła wcześniej międzynarodowe normy, które odnoszą się między innymi do outsourcingu danych, to kwestia powierzania przetwarzania danych podmiotom trzecim nie stanowi na przykład dla gmin

domyślnych (ang. privacy by default). Ich treść wynika z funkcji, jakie powinny spełniać programy służące przetwarzaniu danych osobowych. Koncepcja tych pojęć miała być odpowiedzią na trudności związane z zabezpieczeniem prywatności w związku z postępem technologicznym i rozwojem społeczeństwa informacyjnego.

2 Zob. art. 83 ust. 4 Rozporządzenia Parlamentu Europejskiego i Rady (UE) 2016/679 z dnia 27 kwietnia 2016 r. w sprawie ochrony osób fizycznych w związku z przetwarzaniem danych osobowych i w sprawie swobodnego przepływu takich danych oraz uchylenia dyrektywy 95/46/WE (RODO).

${ }^{3}$ Zob. tamże, art. 83 ust. 5.

${ }^{4}$ E. Wolska, Audyt zgodności z norma ISO - IEC 27001:27005, „Zeszyty Naukowe Warszawskiej Wyższej Szkoły Informatyki” 2012, nr 7, s. 80. 
większych trudności5 Samorządy coraz chętniej sięgają po nowoczesne metody służące poprawie jakości usług i jak się okazuje, tam, gdzie wcześniej były wdrożone normy ISO, spokojniej przebiegał proces dostosowania danej jednostki do RODO i funkcjonowania w niej nowych przepisów.

Tabela 1. Związek ISO 20071 z wymaganiami RODO

\begin{tabular}{|c|c|c|c|}
\hline \multirow{4}{*}{27001} & $\begin{array}{l}\text { Polityka } \\
\text { bezpieczeństwa }\end{array}$ & art. 24 ust. 2 & $\begin{array}{l}\text { Jeżeli jest to proporcjonalne w stosunku do czynności przetwarzania, } \\
\text { środki, o których mowa w ust. 1, obejmują wdrożenie przez administrato- } \\
\text { ra odpowiednich polityk ochrony danych. }\end{array}$ \\
\hline & Kontrola dostępu & art. 5 ust. $1 f$ & $\begin{array}{l}\text { Dane osobowe muszą być [...] przetwarzane w sposób zapewniający } \\
\text { odpowiednie bezpieczeństwo danych osobowych, w tym ochronę przed } \\
\text { niedozwolonym lub niezgodnym z prawem przetwarzaniem oraz } \\
\text { przypadkową utratą, zniszczeniem lub uszkodzeniem, za pomocą } \\
\text { odpowiednich środków technicznych lub organizacyjnych („integralność } \\
\text { i poufność”). }\end{array}$ \\
\hline & $\begin{array}{l}\text { Zarządzanie } \\
\text { ciągłością działania }\end{array}$ & art. 32 ust. 2 & $\begin{array}{l}\text { Oceniając, czy stopień bezpieczeństwa jest odpowiedni, uwzględnia się } \\
\text { w szczególności ryzyko wiążące się z przetwarzaniem, w szczególności } \\
\text { wynikające z przypadkowego lub niezgodnego z prawem zniszczenia, } \\
\text { utraty, modyfikacji, nieuprawnionego ujawnienia lub nieuprawnio- } \\
\text { nego dostępu do danych osobowych przesyłanych, przechowywanych } \\
\text { lub w inny sposób przetwarzanych. }\end{array}$ \\
\hline & $\begin{array}{l}\text { Zarządzanie } \\
\text { incydentami } \\
\text { związanymi } \\
\text { z bezpieczeństwem } \\
\text { informacji }\end{array}$ & motyw 49 & $\begin{array}{l}\text { Przetwarzanie danych osobowych w zakresie bezwzględnie niezbędnym } \\
\text { i proporcjonalnym do zapewnienia bezpieczeństwa sieci i informacji } \\
\text { [...] oraz bezpieczeństwa związanych z nimi usług oferowanych lub } \\
\text { udostępnianych poprzez te sieci i systemy przez organy publiczne, ze- } \\
\text { społy reagowania na zagrożenia komputerowe, zespoły reagowania na } \\
\text { komputerowe incydenty naruszające bezpieczeństwo, dostawców } \\
\text { sieci i usług łączności elektronicznej oraz dostawców technologii i usług } \\
\text { w zakresie bezpieczeństwa jest prawnie uzasadnionym interesem admi- } \\
\text { nistratora, którego sprawa dotyczy. }\end{array}$ \\
\hline
\end{tabular}

Źródło: S. Stefaniak, H. Suszek-Borowska, O. Budziszewska, Zabezpieczanie i analizowanie ryzyk przetwarzania danych osobowych, [w:] P. Sikorski (red.), Ochrona danych osobowych - poradnik dla małych i średnich przedsiębiorców, Polska Agencja Rozwoju Przedsiębiorczości, Warszawa 2017, s. 87

\section{RODO w zamówieniach publicznych realizowanych przez jednostki samorządowe}

Gmina (jako zamawiający) przetwarza dane wykonawców na przykład ujawnione w ofertach, dane osób reprezentujących, dane dotyczące realizacji obowiązku zatrudnienia na podstawie umowy o pracę czy też dane osobowe zawarte w KRS, KRK, wykazach usług, robót budowlanych itp., które są dostarczane na wezwanie. Gmina również ujawnia dane osób fizycznych i wtedy to wykonawcy stają się podmiotami przetwarzającymi, na przykład gdy gmina udostępnia nazwiska członków komisji przetargowej, dane osób, z którymi należy się kontaktować w sprawie ogłoszonego przetargu, czy też dane niezbędne do realizacji umowy przy zamówieniach na ochronę, budowę systemów informatycznych, zamówienia archiwizacyjne itp. RODO ma znaczący wpływ na relację samorząd-przedsiębiorca w od-

${ }^{5}$ Zob. A. Popowicz-Pazdej, Ochrona danych osobowych: Wdrożenie ISO 27001 pomoże przy implementacji RODO, ale nie zastapi analizy indywidualnych uwarunkowań, https://prawo.gazetaprawna. pl/artykuly/1076816,rodo-ochrona-danych-osobowych-wdrozenie-iso-27001.html [dostęp: 10.11.2018]. 
niesieniu do zamówień publicznych, gdzie zarówno na zamawiającego, jak i wykonawcę zostały nałożone nowe obowiązki.

RODO chroni dane osób fizycznych, a zatem wydawać by się mogło, że nie w każdym postępowaniu o udzielenie zamówienia powinny znaleźć zastosowanie nowe regulacje prawne, albowiem większość zamówień jest udzielana osobom prawnym. Nic bardziej mylnego! Należy pamiętać, że nawet jeśli wykonawcą nie jest osoba fizyczna prowadząca działalność gospodarczą, to zamawiający i tak otrzymuje dane osób fizycznych, które są zatrudnione przez daną osobę prawną, a zatem stosowanie przepisów RODO w zamówieniach publicznych jest niezbędne, by prowadzić procedurę zamówieniową zgodnie z prawem na wszystkich jej etapach.

W początkowym okresie wdrażania rozporządzania kłopotliwe dla stron postępowania o udzielenie zamówienia było to, czy nowe przepisy odnoszą się do postępowań już wszczętych, czy wyłącznie do tych, które dopiero będą się rozpoczynały i przede wszystkim to, w jaki sposób chronić dane osób i podmiotów biorących udział w przetargu. Naprzeciw tym wątpliwościom wyszedł Urząd Zamówień Publicznych, który wskazał, że nowe przepisy odnoszą się do postępowań zarówno rozpoczętych z dniem 25 maja 2018 roku, jak i postępowań wszczętych wcześniej, pod warunkiem że toczyły się nadal po wejściu w życie rozporządzenia, tj. po 25 maja 2018 roku. W takich przypadkach zamawiający miał obowiązek uwzględnić nowe przepisy przy pierwszej czynności podejmowanej z wykonawcą, którą zwykle jest wymiana korespondencji ${ }^{6}$.

\section{Obowiązek informacyjny ciążący na gminie jako administratorze danych osobowych}

Administratorem danych osobowych pozyskiwanych w związku z ogłaszanym przez urząd gminy konkursem ofert na udzielenie zamówienia jest gmina, albowiem to ona występuje w charakterze zamawiającego. Zgodnie z art. 7 pkt 4 Ustawy z dnia 10 maja 2018 r. o ochronie danych osobowych ${ }^{7}$ (dalej: u.o.d.o.) za administratora danych uznaje się organ, jednostkę organizacyjną bądź podmiot lub osobę, do której odnoszą się przepisy ustawy decydujące o celach i środkach przetwarzania danych osobowych. Jak stanowi art. 13 RODO, jednym z podstawowych obowiązków administratora jest obowiązek informacyjny wobec osób fizycznych, których dane gmina pozyskuje i przetwarza. Rozporządzenie przewiduje spełnienie obowiązku informacyjnego w trzech formach: pisemnej, elektronicznej lub ustnej. Te dwie pierwsze są najbezpieczniejsze w kontekście zasady rozliczalności, ponieważ w razie konieczności wykazania, że obowiązek informacyjny został spełniony, administrator będzie miał dowody na piśmie ${ }^{8}$. Dlatego też w przypadku zamówienia publicznego to admi-

${ }^{6}$ Zob. J. Rek-Pawłowska, RODO w zamówieniach publicznych - 5 najważniejszych wskazówek $U Z P$, https://www.portalzp.pl/nowosci/rodo-w-zamowieniach-publicznych-5-najwazniejszych-wskazowek-uzp-8682.html [dostęp: 10.11.2018].

${ }^{7}$ Ustawa z dnia 10 maja 2018 r. o ochronie danych osobowych, Dz.U. 2018, poz. 1000.

${ }^{8}$ Zob. B. Mendyk, Przedmiot ochrony-podstawowe pojęcia, [w:] P. Sikorski (red.), Ochrona danych osobowych - poradnik dla matych i średnich przedsiębiorców, Polska Agencja Rozwoju Przedsiębiorczości, Warszawa 2017, s. 32. 
nistrator powinien zamieścić w Specyfikacji Istotnych Warunków Zamówienia, ogłoszeniu o zamówieniu, konkursie lub w regulaminie klauzulę informacyjną, z której będzie wynikało między innymi to, jaki podmiot przetwarza dane, po co są przetwarzane i jak długo będą w posiadaniu administratora. Jeżeli gmina nie zrobiła tego na etapie ogłoszenia przetargu, powinna niezwłocznie tego obowiązku dopełnić na przykład za pośrednictwem korespondencji z wykonawcami, którzy złożyli swoje oferty.

Warto podkreślić, że o ile podmiot przystępujący do postępowania posiada prawo dostępu do swoich danych (art. 15 RODO), prawo do ich sprostowania (art. 16 RODO) oraz żądania od administratora ograniczenia przetwarzania danych poza sytuacjami, w których dane są przechowywane w celu zapewnienia korzystania ze środków ochrony prawnej lub w celu ochrony praw innej osoby fizycznej lub prawnej, lub z uwagi na ważne względy interesu publicznego Unii Europejskiej lub państwa członkowskiego (art. 18 ust. 2 RODO), a także posiada prawo do wniesienia skargi do prezesa Urzędu Ochrony Danych Osobowych, o tyle jest pozbawiony prawa do usunięcia danych osobowych w imię przepisów zawartych w art. 17 ust. 3 lit. b, d lub e RODO. Istnieje kilka okoliczności ujętych w zamkniętym katalogu, które wyłączają prawo do bycia zapomnianym - jest to między innymi sytuacja, w której administrator przetwarza dane w związku z ciążącym na nim ustawowym obowiązkiem prawnym oraz gdy wykonywane zadanie jest w interesie publicznym lub w ramach władzy publicznej powierzonej administratorowi ${ }^{9}$. Poza tym wykonawca nie ma prawa do przenoszenia danych osobowych, do czego nawiązuje art. 20 RODO oraz nie może podnieść sprzeciwu wobec przetwarzania danych osobowych, gdyż podstawą prawną przetwarzania danych osobowych przez gminę jest art. 6 ust. 1 lit. c RODO, który stanowi, że ,przetwarzanie jest niezbędne do wypełnienia obowiązku prawnego ciążącego na administratorze", o czym podmiot zainteresowany zostaje poinformowany za pośrednictwem przygotowanej przez daną jednostkę organizacyjną klauzuli informacyjnej. Trzeba też dodać, że jeżeli wykonawca chciałby skorzystać z przysługującego mu prawa do sprostowania swoich danych, to czynność ta nie może mieć wpływu na wynik postępowania o udzielenie zamówienia ani też nie może skutkować zmianą postanowień umowy w zakresie, którego p.z.p. nie przewiduje.

\section{Dane osobowe zamieszczane w Biuletynie Zamówień Publicznych}

Ustawa z dnia 29 stycznia 2004 r. Prawo zamówień publicznych ${ }^{10}$ (dalej: p.z.p.) nie reguluje kwestii związanych z przetwarzaniem danych osobowych w Biuletynie Zamówień Publicznych, przez co wykonawcy często poddają pod wątpliwość zakres informacji podawanych do publicznej wiadomości w związku z nowymi przepisami o ochronie danych osobowych. Jak wspomniano wcześniej, zakres przedmiotowy ustawy o ochronie danych osobowych oraz unijnego rozporządzenia dotyczy danych osób fizycznych. Wszelkiego rodzaju ograniczenia wynikające z regulacji odnoszących się do danych osobowych nie mają

${ }^{9}$ Zob. B. Mendyk, Prawa osób, których dane dotycza, czyli inne obowiązki administratora, [w:] P. Sikorski (red.), Ochrona danych osobowych - poradnik dla matych i średnich przedsiębiorców, Polska Agencja Rozwoju Przedsiębiorczości, Warszawa 2017, s. 56-57.

${ }^{10}$ Ustawa z dnia 29 stycznia 2004 r. Prawo zamówień publicznych, Dz. U. 2018, poz. 1986. 
zastosowania do podmiotów posiadających osobowość prawną lub jednostek organizacyjnych nieposiadających tej osobowości czy też podmiotów działających w oparciu o przepisy Ustawy z dnia 2 lipca 2004 r. o swobodzie działalności gospodarczej ${ }^{11}$. Zatem jeżeli zamówienie publiczne zostanie udzielone przedsiębiorcy będącemu osobą fizyczną, którego dane osobowe jednocześnie są danymi identyfikującymi jego firmę, to nie może jako osoba fizyczna żądać od gminy nieujawnienia tych danych na przykład w Biuletynie Zamówień Publicznych. Naczelny Sąd Administracyjny w wyroku z dnia 28 listopada 2002 r., który dotyczył przetwarzania informacji o charakterze osobowym osób prowadzących działalność gospodarczą, podkreślił, że osoba decydująca się na działalność gospodarczą godzi się na ograniczenie swojego prawa prywatności w większym zakresie niż osoba fizyczna, która takiej działalności nie podejmuje. Jeżeli informacje zawarte w umowie są przez kontrahenta nadużywane do innych celów, aniżeli przewiduje treść zawartej umowy, wtedy podniesienie sprzeciwu byłoby zasadne ${ }^{12}$. Ponieważ w zamówieniach publicznych obowiązuje zasada jawności postępowania (art. 8 p.z.p.), to na mocy przepisów odnoszących się do ogłoszeń zamieszczanych w Biuletynie Zamówień Publicznych gwarantuje się dostępność pewnych informacji (w tym danych osobowych) innym zainteresowanym. Każdy uczestnik postępowania, w tym również osoby fizyczne prowadzące działalność gospodarczą, przystępując do przetargu, już przez sam fakt zadeklarowania swojego uczestnictwa godzą się na upublicznienie treści zawierających ich dane osobowe, jeżeli zamówienie zostanie im udzielone, a w przypadku negocjacji bez ogłoszenia i zamówień z wolnej ręki godzą się na ujawnienie swoich danych jeszcze przed udzieleniem zamówienia ${ }^{13}$. Urząd Zamówień Publicznych jest administratorem danych, które są umieszczane przez zamawiających za pośrednictwem odpowiednich formularzy elektronicznych, ale nie posiada uprawnień do zmiany ich treści. Przepisy p.z.p. są przepisami szczególnymi w stosunku do u.o.d.o. Art. 23 ust. 1 wskazanej ustawy dopuszcza przetwarzanie danych, jeżeli jest to niezbędne dla zrealizowania uprawnienia lub spełnienia obowiązku wynikającego z przepisu prawa. Urząd Zamówień Publicznych posiada zatem kompetencje do przetwarzania danych osobowych, ponieważ realizuje obowiązki wynikające z przepisów p.z.p. oraz aktów wykonawczych tejże ustawy ${ }^{14}$.

\section{Podsumowanie}

Mimo licznych trudności i zdarzających się pomyłek wynikających z niewłaściwego interpretowania przepisów RODO można uznać, że administracja publiczna radzi sobie niekiedy lepiej z nowymi przepisami aniżeli przedsiębiorcy, czego przykładem jest sprawa o przywrócenie terminu rozpatrywana przez Wojewódzki Sąd Administracyjny

${ }^{11}$ Ustawa z dnia 2 lipca 2004 r. o swobodzie działalności gospodarczej, Dz.U. 2013, poz. 672.

12 Zob. Wyrok NSA z dnia 28 listopada 2002 r., sygn. akt II SA 3389/01.

${ }_{13}$ Zob. Dane osobowe wykonawców zamieszczane w Biuletynie Zamówień Publicznych, Urząd Zamówień Publicznych, https://www.uzp.gov.pl/baza-wiedzy/interpretacja-przepisow/opinie-dotyczace-ustawy-pzp/inne/dane-osobowe-wykonawcow-zamieszczane-w-biuletynie-zamowien-publicznych [dostęp: 8.11.2018].

${ }^{14}$ Zob. tamże. 
we Wrocławiu. Jedna ze stron przez reorganizację związaną z RODO zagubiła bardzo ważne dokumenty, przez co nie wywiązała się w terminie ze swojego zobowiązania. Sąd w swoim postanowieniu ocenił, że strona składająca wniosek o przywrócenie terminu dołożyła wszelkiej staranności, aby zaginioną dokumentację odnaleźć, a mimo to użycie wysiłku w danych warunkach nie usunęło przeszkody ${ }^{15}$. Z treści postanowienia można wysnuć wniosek, że skład orzekający miał świadomość, iż kompleksowe wdrażanie nowych przepisów może w danej jednostce być źródłem chaosu skutkującego niewywiązaniem się ze swoich zadań w terminie. Eksperci oceniają, że upłynęło zbyt mało czasu, aby wyciągać daleko idące wnioski, ale na pewno daje się już zauważyć, że najwięcej pytań i trudności w samorządach pojawiło się na etapie zawierania umów powierzenia przetwarzania danych osobowych z innymi podmiotami. Rozbieżne interpretacje przepisów odnoszące się na przykład do zasadności podpisywania takich umów wprowadzają jednostki w błąd. Samorządy musiały się zmierzyć z oceną dotychczasowego systemu przetwarzania danych, a zakres zgromadzonych informacji zweryfikować pod kątem celowości i zasady minimalizmu. Niewątpliwie wiele wysiłku kosztowała weryfikacja treści uchwał, instrukcji, wniosków i regulaminów w kontekście unijnego rozporządzenia, ale samorządy, mając wsparcie IODO, dobrze sobie z tym radzą. Ponieważ rozporządzenie w swojej treści często wyznacza wyłącznie cel (bez wskazania środków do jego realizacji), dla wielu jednostek samorządu terytorialnego bardzo pomocne stały się mechanizmy norm z zakresu zarządzania bezpieczeństwem informacji (ISO z grupy 27001 - systemy zarządzania bezpieczeństwem informacji, 27002 - zasady zarządzania bezpieczeństwem informacji, 27005 - zarządzanie ryzykiem).

\section{Bibliografia}

Mendyk B., Prawa osób, których dane dotycza, czyli inne obowiązki administratora, [w:] P. Sikorski (red.), Ochrona danych osobowych - poradnik dla matych i średnich przedsiębiorców, Polska Agencja Rozwoju Przedsiębiorczości, Warszawa 2017.

Mendyk B., Przedmiot ochrony - podstawowe pojęcia, [w:] P. Sikorski (red.), Ochrona danych osobowych - poradnik dla matych i średnich przedsiębiorców, Polska Agencja Rozwoju Przedsiębiorczości, Warszawa 2017.

Popowicz-Pazdej A., Ochrona danych osobowych: Wdrożenie ISO 27001 pomoże przy implementacji RODO, ale nie zastapi analizy indywidualnych uwarunkowań, https://prawo.gazetaprawna.pl/artykuly/1076816,rodo-ochrona-danych-osobowych-wdrozenie-iso-27001.html [dostęp: 10.11.2018].

Rek-Pawłowska J., RODO w zamówieniach publicznych - 5 najważniejszych wskazówek UZP, https://www.portalzp.pl/nowosci/rodo-w-zamowieniach-publicznych-5-najwazniejszych-wskazowek-uzp-8682.html [dostęp: 10.11.2018].

Stefaniak S., Suszek-Borowska H., Budziszewska O., Zabezpieczanie i analizowanie ryzyk przetwarzania danych osobowych, [w:] P. Sikorski (red.), Ochrona danych osobowych-poradnik dla małych i średnich przedsiębiorców, Polska Agencja Rozwoju Przedsiębiorczości, Warszawa 2017.

${ }^{15}$ Zob. Postanowienie WSA we Wrocławiu z dnia 12 września 2018 r., sygn. akt II SA/Wr 493/18. 
Dane osobowe wykonawców zamieszczane w Biuletynie Zamówień Publicznych, Urząd Zamówień Publicznych, https://www.uzp.gov.pl/baza-wiedzy/interpretacja-przepisow/opinie-dotyczace-ustawy-pzp/inne/dane-osobowe-wykonawcow-zamieszczane-w-biuletynie-zamowien -publicznych [dostęp: 8.11.2018].

Wolska E., Audyt zgodności z norma ISO - IEC 27001:27005, „Zeszyty Naukowe Warszawskiej Wyższej Szkoły Informatyki” 2012, nr 7.

\section{Akty prawne}

Postanowienie WSA we Wrocławiu z dnia 12 września 2018 r., sygn. akt II SA/Wr 493/18.

Rozporządzenie Parlamentu Europejskiego i Rady (UE) 2016/679 z dnia 27 kwietnia 2016 r. w sprawie ochrony osób fizycznych w związku z przetwarzaniem danych osobowych i w sprawie swobodnego przepływu takich danych oraz uchylenia dyrektywy 95/46/WE (RODO).

Ustawa z dnia 29 stycznia 2004 r. Prawo zamówień publicznych, Dz.U. 2018, poz. 1986.

Ustawa z dnia 2 lipca 2004 r. o swobodzie działalności gospodarczej, Dz.U. 2013, poz. 672.

Ustawa z dnia 10 maja 2018 r. o ochronie danych osobowych, Dz.U. 2018, poz. 1000.

Wyrok NSA z dnia 28 listopada 2002 r., sygn. akt II SA 3389/01.

\section{Streszczenie \\ Unijne przepisy o ochronie danych osobowych w jednostkach samorządu terytorialnego}

Zatrudnienie inspektora ochrony danych osobowych, pozyskiwanie zgody na przetwarzanie danych, obowiązkowe zgłaszanie naruszeń i powiadomienie podmiotu zainteresowanego, uściślenie obowiązków podmiotów przetwarzających dane oraz korzystanie ze zmienionych przepisów odnoszących się do międzynarodowego przekazywania danych osobowych to nowe zasady, z wdrożeniem których niedawno musiały się zmierzyć m.in. jednostki samorządu terytorialnego na mocy unijnego Rozporządzenia Parlamentu Europejskiego i Rady (UE) 2016/679 z dnia 27 kwietnia 2016 r. w sprawie ochrony osób fizycznych w związku z przetwarzaniem danych osobowych i w sprawie swobodnego przepływu takich danych oraz uchylenia dyrektywy 95/46/WE (RODO). Istotne zmiany zaszły na poziomie zamówień publicznych realizowanych przez samorządy, gdzie wykonawca jest pozbawiony prawa do usunięcia danych, ich przenoszenia oraz nie może podnieść sprzeciwu wobec ich przetwarzania.

Słowa kluczowe: samorząd terytorialny, ochrona danych osobowych, obowiązek informacyjny, administrator danych, zamówienia publiczne 


\section{Summary \\ EU regulations on the protection of personal data in local government units}

The Regulation (EU) 2016/679 of the European Parliament and of the Council of 27 April 2016 on the protection of natural persons with regard to the processing of personal data and on the free movement of such data, and repealing Directive 95/46/EC (General Data Protection Regulation) imposed new duties on local self-government units commencing on May 2018. Employing a Personal Data Protection Officer, obtaining consent to data processing, mandatory reporting of violations and notifying the interested party, detailing of the duties of data processors and the application of amended provisions regarding international data transfers constituted the new rules which had to be implemented. Major changes have occurred on the level of public contracts performed by local governments, whereby the contractor no longer has the right to remove data, transfer data, and cannot object against the processing of the data.

Keywords: local government, personal data protection, disclosure requirements, data controller, public contracts 
Jakub Olech (iD https://orcid.org/0000-0001-9173-8761

Urząd Marszałkowski Województwa Małopolskiego

\section{Modele sądowej kontroli administracji - próba syntezy}

\section{Wprowadzenie}

Status obywatela $\mathrm{w}$ zetknięciu $\mathrm{z}$ administracją publiczną diametralnie zmienił się na przestrzeni dziejów - od poddanych, którzy byli własnością swoich władców, do czasów, gdy ludzie, już jako obywatele, mogą zabiegać o swoje prawa, używając do tego różnych instrumentów, w jakie to prawo ich wyposaża. Najważniejszą zdobyczą w tej dziedzinie jest oczywiście sądownictwo, które w obszarze administracji, począwszy od XIX wieku, ewoluuje, stale kształtując ramy relacji między państwem i obywatelem. Warto bliżej przyjrzeć się tym ramom. Aby zrobić to pełniej, należy bez wątpienia prześledzić historyczne modele sądownictwa administracyjnego oraz przeanalizować współczesne kształtowanie jego uprawnień, biorąc pod uwagę tradycje i kultury prawne, w których się rozwinęły. Syntetyczne spojrzenie na te zagadnienia przyczynia się bowiem istotnie do charakterystyki modelu sądownictwa administracyjnego oraz przyczyn, które nadały mu ostateczny kształt, a także, w pewnej mierze, do oceny jego skuteczności, przejrzystości funkcjonowania oraz próby zakreślenia rozwiązań, które mogą stanowić ewentualny wzorzec dla innych tradycji prawnych lub obszarów, w jakich warto zastanowić się nad zmianami. Na tę ostatnią grupę zagadnień warto spojrzeć z perspektywy polskiego systemu sądownictwa administracyjnego, który w porządku prawnym Rzeczpospolitej funkcjonuje krócej niż w innych krajach, choć liczy sobie już prawie wiek. 


\section{Prawo do sądu jako publiczne prawo podmiotowe}

Rewolucja francuska i epoka napoleońska ostatecznie pogrzebały państwo absolutyzmu oświeconego oraz jego twory i zdobycze, w tym także te z zakresu administracji. Do historii odchodziła niezachwiana pozycja władcy jako stojącego ponad prawem, ale stanowiącego prawo, nieomylnego suwerena. Wraz z nim kończyła się epoka uznaniowej administracji, pozbawionej kontroli i całkowicie niezależnej od obywatela. Pierwsza połowa XIX wieku to czas, kiedy w Niemczech rodzi się konstrukcja państwa prawnego (Reichsrat). Pojawiają się pierwsze konstytucje, które wiążą monarchów, parlamenty, a także administrację. Powstaje nowoczesne pojęcie hierarchiczności aktów prawnych, na których czele znajduje się konstytucja. Administracja musi bezwzględnie przestrzegać prawa oraz działać w jego granicach. Likwidacji ulega stan, w którym administracja w każdym momencie mogła ingerować w dowolną dziedzinę aktywności obywateli. Rodzi się kontrola zewnętrzna, zarówno ze strony legislatywy, jak i judykatywy ${ }^{1}$. W ten oto sposób państwo prawa doprowadza do sytuacji, w której instytucje państwa zyskują nie tylko swe zakotwiczenie w prawie, lecz także konieczność funkcjonowania w oparciu o nie. Właśnie ten czas możemy datować jako początek prawa administracyjnego, w oparciu o które administracja publiczna działa po dzień dzisiejszy.

Fundamenty państwa prawnego zostały więc zapisane w konstytucjach, które zaczęły obowiązywać bezwzględnie wszystkich, także monarchów, zaś akty prawne zyskały swoją, również powszechnie obowiązującą, hierarchię. Przepisy prawne zaczęły być uchwalane przez parlamenty, nie zaś oktrojowane przez władców, natomiast normy prawa administracyjnego zaczęły mieć w państwie prawnym charakter dwustronnie obowiązujący ${ }^{2}$. Fakt, iż normą prawa administracyjnego związany staje się nie tylko obywatel, ale też organ administracji, jest milowym krokiem na drodze rozwoju administracji. Jest on również korzeniem, z jakiego wyrasta sądownictwo administracyjne, które w drugiej połowie XIX wieku zaczyna pojawiać się w państwach prawa.

Zasadnicze znaczenie dla sądownictwa administracyjnego miało powołanie do życia w Austrii w 1875 roku Trybunału Administracyjnego, który miał prawo uchylania orzeczeń i zarządzeń władz administracyjnych ${ }^{3}$. Po raz pierwszy w historii powołano sąd, którego głównym zadaniem była kontrola aktów administracyjnych. Jednak powstanie w Wiedniu Trybunału Administracyjnego, a jego wzorem innych sądów tego typu, miało ogromne znaczenie także, a może nawet przede wszystkim, dla obywateli, było bowiem swego rodzaju uznaniem przez państwo publicznych praw podmiotowych, których pojęcie zaczęło wówczas zaznaczać się w naukach prawnych. Wśród wielu definicji publicznych praw podmiotowych, które w swojej monografii Prawo administracyjne zebrał Jan Zimmermann, szczególnie warta przytoczenia jest definicja Kazimierza Opałka, dla którego publiczne prawo podmiotowe jest pewnego rodzaju powiązaniem normatywnym opartym na czynniku

${ }^{1}$ J. Malec, D. Malec, Historia administracji i myśli administracyjnej, Wydawnictwo Uniwersytetu Jagiellońskiego, Kraków 2003, s. 117.

2 Tamże, s. 117.

${ }^{3}$ M. Wierzbowski, M. Szubiakowski, A. Wiktorowska (red.), Postępowanie administracyjne, Wydawnictwo C.H. Beck, Warszawa 2006, s. 5. 
woli zbiorowej zdeterminowanej przez obiektywną sytuację danej zbiorowości, ukierunkowanej przez jej obiektywne interesy i formułowanej przez najbardziej świadomą część tej zbiorowości ${ }^{4}$. Trudno o bardziej trafny opis sytuacji ukształtowania się publicznych praw podmiotowych, gdzie wola zbiorowa wyraża się przez wystąpienia obywateli, począwszy od tych zbrojnych, jak Wiosna Ludów, skończywszy na rywalizacji w wyborach i parlamentach, które w XIX wieku pisały konstytucje poszczególnych państw. Na potrzeby refleksji nad prawem administracyjnym Zimmermann stwierdza, iż publiczne prawa podmiotowe można określać jako sytuacje, w których od zachowania konkretnej osoby stojącej poza władzą publiczną zależy, czy dla tej władzy powstanie obowiązek oparty na prawie. Takie sformułowanie zaś oznacza, że podmiot posiadający publiczne prawo podmiotowe ma prawo do samodzielnego wyznaczenia obowiązków administracji publicznej w określonym zakresie ${ }^{5}$.

Jednym z podstawowych publicznych praw podmiotowych jest prawo do sądu, które możemy określić jako prawo jednostki wobec państwa uosabianego przez jego organy sądownicze. Tak sformułowane prawo do sądu wymaga konkretyzacji i stworzenia systemu zabezpieczeń i gwarancji, dzięki którym owo publiczne prawo podmiotowe będzie w należytym stopniu przestrzegane i chronione ${ }^{6}$. Elementem tego systemu jest właśnie sądownictwo administracyjne, którego głównym zadaniem jest ochrona praw jednostek oraz realizacja publicznego prawa podmiotowego, jakim jest prawo do sądu. Zadaniem tym jest również kontrola działalności organów państwowych.

\section{Ukształtowanie sądownictwa administracyjnego - zasadnicze modele}

Od czasu powstania sądownictwa administracyjnego na świecie ukształtowały się różne typy sądownictwa w zakresie spraw administracyjnych. Wyróżnić możemy trzy zasadnicze modele sądowej kontroli administracji. Pierwszy przypadek ma miejsce wtedy, gdy jest ona wykonywana przez sądy powszechne. Drugi, gdy kontroli dokonują wyłącznie w tym celu powołane sądy administracyjne. Wreszcie trzeci model, w którym kontroli dokonują zarówno sądy powszechne, jak i sądy administracyjne?

Ukształtowały się również różne metody określania właściwości i uprawnień sądów administracyjnych. Dwie zasadnicze to klauzula enumeracyjna i klauzula generalna. Klauzula enumeracyjna szczegółowo wskazuje, w jakich sprawach sąd może orzekać ${ }^{2}$. Mieliśmy z nią do czynienia w sądownictwie administracyjnym PRL, o czym niżej. Obecnie jest ona ciągle stosowana na przykład w Czechach ${ }^{9}$. Natomiast klauzula generalna przyznaje

${ }^{4}$ J. Zimmermann, Prawo administracyjne, Zakamycze, Kraków 2005, s. 323.

5 J. Zimmermann, dz. cyt., s. 325.

${ }^{6}$ T. Woś, H. Knysiak-Molczyk, M. Romańska, Postępowanie sądowo-administracyjne, LexisNexis, Kraków 2004, s. 19 i nast.

7 Tamże, s. 22.

8 J. Malec, D. Malec, dz. cyt., s. 225.

9 R. Chrabąszcz, J. Hausner, S. Mazur, Administracja publiczna w wybranych krajach Europy Środkowo-wschodniej, Wydawnictwo Akademii Ekonomicznej w Krakowie, Kraków 2003, s. 46. 
sądowi właściwość rozpatrywania skarg na wszystkie decyzje administracyjne wydane z naruszeniem prawa ${ }^{10}$.

Duże znaczenie w procedowaniu spraw przez sądy, także w przypadku spraw administracyjnych, ma liczba instancji, w których się owo procedowanie odbywa. Zasadniczo mamy do czynienia z trzema modelami obejmującymi od jednej do trzech instancji. Klasyczny już przykład austriackiego Trybunału Administracyjnego to sądownictwo jednoinstancyjne. Model jednoinstancyjnego sądownictwa administracyjnego uznajemy w tej chwili za historyczny. Obecnie, na przykład w Polsce, o czym niżej, orzekają dwie instancje: wojewódzkie sądy administracyjne i Naczelny Sąd Administracyjny. Istnieją również modele trójinstancyjne. W Niemczech jest to związane z federalną strukturą państwa. Mamy więc sądy pierwszej instancji, rozpatrujące odwołania od ich wyroków na poziomie landów sądy drugiej instancji oraz mający charakter rewizyjny Federalny Sąd Administracyjny ${ }^{11}$. We Francji - pierwszym kraju, gdzie pojawiła się idea sądowej kontroli administracji mamy do czynienia z trójinstancyjnością wynikającą niejako z tradycji. Pierwszą instancją są tutaj międzydepartamentalne trybunały administracyjne, drugą sądy apelacyjne, wreszcie trzecią i najwyższą - Rada Stanu ${ }^{12}$.

Powróćmy jednak do wspomnianych powyżej trzech modeli sądowej kontroli administracji, a więc kontroli przez sądy powszechne, przez wyspecjalizowane sądy administracyjne oraz kontroli mieszanej.

Pierwszy model jest niekiedy w literaturze zwany angielskim. Czołowi prawnicy angielscy na czele z Albertem V. Diceyem odmawiali prawu administracyjnemu prawa bytu, uznając jego konstrukcję za oczywiście uprzywilejowującą organy administracji. Ów fakt, połączony z prawotwórczą rolą sądów, z którą mamy do czynienia w systemie common law, powoduje, że w systemie angielskim sądowej kontroli administracji dokonują sądy powszechne. Na wzorcu tym w początkach swego istnienia oparło się także sądownictwo w zakresie administracji na przykład w krajach skandynawskich, a także w Belgii, Holandii, Szwajcarii i we Włoszech ${ }^{13}$. W modelu angielskim przyjmuje się, iż sądy powszechne bardziej bezpośrednio niż specjalne sądy administracyjne będą bronić swobód obywatelskich, prawo administracyjne natomiast nie wyodrębniło się jeszcze w ostateczny sposób $\mathrm{z}$ prawa powszechnego i systemu precedensów ${ }^{14}$. Jednym $\mathrm{z}$ niewielu widomych aspektów kształtowania się wyspiarskiego modelu prawa administracyjnego jest powstanie w XX wieku trybunałów administracyjnych, które w istocie nie są sądami administracyjnymi, ale władzami orzekającymi w obrębie administracji państwowej. Co więcej, od ich orzeczeń można odwoływać się do sądów powszechnych ${ }^{15}$.

Wiele ciekawych rozwiązań, w których sądową kontrolę nad administracją sprawują sądy powszechne, możemy też zaobserwować w Europie Środkowo-Wschodniej, w systemach jak najdalszych od common law. W Rumunii, która wiele rozwiązań ustrojowych przejęła przecież od Francji, próżno szukać podobieństw z francuskim modelem sądownictwa admi-

\footnotetext{
${ }_{10}$ J. Malec, D. Malec, dz. cyt., s. 226.

11 J. Zimmermann, dz. cyt., s. 442.

12 Tamże, s. 442.

13 J. Malec, D. Malec, dz. cyt., s. 225.

14 J. Zimmermann, dz. cyt., s. 438.

${ }^{15}$ H. Izdebski, M. Kulesza, Administracja publiczna-zagadnienia ogólne, Liber, Warszawa 2000, s. 33.
} 
nistracyjnego. W państwie tym w sądach powszechnych utworzone są wydziały administracyjne, zajmujące się skargami w sprawach administracyjnych ${ }^{16}$, podobnie jest w Holandii. Sądy powszechne orzekają też w sprawach administracyjnych, podobnie jak w cywilnych i karnych na przykład do 2013 roku na Węgrzech, a także na Słowacji czy na Łotwie ${ }^{17}$.

Drugi z zaprezentowanych wyżej modeli w różnych formach rozpowszechnił się na kontynencie europejskim. Jego szczególnie charakterystyczne zastosowanie obserwujemy we Francji i Niemczech. Choć powstanie w 1875 roku w Austrii Trybunału Administracyjnego możemy uznać za początek upowszechniania się sądownictwa administracyjnego, to jego źródła biją prawie sto lat wcześniej we Francji. To właśnie tutaj w czasie Wielkiej Rewolucji Francuskiej przyjęła się zasada wyjęcia spraw administracyjnych spod jurysdykcji sądów powszechnych ${ }^{18}$. Przeszło dwieście lat tradycji sprawia, że francuskie sądownictwo administracyjne uznawane jest przez badaczy przedmiotu za najbardziej rozwinięte, ale także za do tego stopnia specyficzne, iż trudno o przyjęcie jego reguł i sposobu funkcjonowania w innych krajach. Sądownictwo administracyjne jest oto we Francji częścią administracji publicznej, zaś jego najwyższym organem jest Rada Stanu, która z kolei organizacyjnie stanowi część administracji rządowej podległej premierowi i przez niego kierowanej ${ }^{19}$. Co ciekawe, francuskie sądownictwo administracyjne przez wiele lat kierowało się zasadami precedensu wypracowywanymi przez poszczególne sądy. Dopiero 1 stycznia 2001 roku wszedł w życie pierwszy w historii Francji kodeks sądownictwa administracyjnego ${ }^{20}$. Wśród charakterystycznych rozwiązań modelu francuskiego jest również funkcjonowanie w nim tak zwanych kontraktów administracyjnych, które są rodzajem umów cywilnoprawnych, gdzie jedną stroną jest organ administracji. Ewentualne spory związane z takimi kontraktami rozstrzygają sądy administracyjne. Pod jurysdykcją tych sądów jest także odpowiedzialność państwa za szkody wyrządzone przez jego funkcjonariuszy oraz objęcie kontrolą sądów administracyjnych aktów administracyjnych o charakterze generalnym ${ }^{21}$.

Mniejszy stopień skomplikowania i różnorodności jest udziałem sądownictwa administracyjnego, którego model wypracowali Niemcy. Po pierwsze, działalność niemieckich sądów administracyjnych opiera się wyłącznie na regulacjach ustawowych, nie zaś na precedensach. Po drugie, przedmiotem kontroli jest zwłaszcza akt administracyjny. Po trzecie, kontrola sądów oparta jest wyłącznie na kryterium legalności. Po czwarte, sądy administracyjne nie orzekają w sprawach cywilnych. Po piąte wreszcie, niemieckie sądy administracyjne nie są wyposażone w merytoryczne kompetencje ${ }^{22}$. Oznacza to, iż sąd może wskazać, czy dany akt administracyjny jest zgodny z prawem, czy nie, jednak ewentualne zmiany bądź likwidacja skutków aktu, którego legalność sąd zakwestionował, leżą już po stronie organu administracji. Sądownictwo administracyjne Austrii, od czasu powstania Trybunału Administracyjnego, a za nim sądownictwo administracyjne Niemiec przyjęły za zasadę, iż do sądu

\footnotetext{
${ }^{16}$ R. Chrabąszcz, J. Hausner, S. Mazur, dz. cyt., s. 106.

17 Tamże, s. 90, 149.

${ }^{18}$ H. Izdebski, M. Kulesza, dz. cyt., s. 35.

${ }_{19}$ P. Sarnecki, Ustroje konstytucyjne państw wspótczesnych, Zakamycze, Kraków 2004, s. 317.

20 J. Zimmermann, dz. cyt., s. 438.

${ }^{21}$ H. Izdebski, M. Kulesza, dz. cyt., s. 36.

22 J. Zimmermann, dz. cyt., s. 439.
} 
administracyjnego można skarżyć się dopiero po wyczerpaniu środków przysługujących w ramach postępowania administracyjnego ${ }^{23}$.

Trzecim z zasadniczych modeli sądowej kontroli administracji jest model mieszany, w którym kontrola odbywa się zarówno za pośrednictwem specjalnie do tego powołanych sądów administracyjnych, jak i poprzez sądy powszechne. W Bułgarii przez lata obserwowaliśmy model, w którym w pierwszej instancji w sprawach administracyjnych orzekają sądy powszechne, zaś w drugiej naczelny sąd administracyjny ${ }^{24}$. W Polsce również mamy do czynienia z modelem mieszanym, tyle że o nieco większym stopniu skomplikowania. Jednak przed szerszym omówieniem jego istoty warto zapoznać się z ewolucją polskiego sądownictwa administracyjnego.

\section{Sądowa kontrola administracji w Polsce}

Czasy zaborów sprawiły, że poszczególne części Polski znajdowały się pod jurysdykcją systemów trzech różnych państw, z których w zakresie prawa i sądownictwa administracyjnego najlepiej oceniano system austriacki. Takie było przynajmniej odczucie tych, którzy budując II Rzeczpospolitą, postanowili oprzeć kontrolę administracji rodzącego się państwa na wzorcach austriackich. W konstytucji II RP z 17 marca 1921 roku zapisano, że do orzekania o legalności aktów administracyjnych zostanie powołane sądownictwo administracyjne zbudowane na zasadzie współdziałania czynnika sędziowskiego i obywatelskiego ${ }^{25}$. Obietnicę tę udało się spełnić jedynie częściowo, bowiem ustawą z 3 sierpnia 1922 roku powołano do życia Naczelny Trybunał Administracyjny, który istniał do 1939 roku, jednak nigdy nie stworzono sądownictwa administracyjnego niższych instancji. Dlatego na ziemiach byłego zaboru austriackiego i rosyjskiego kontrola administracji odbywała się według modelu jednoinstancyjnego, jak miało to miejsce wcześniej w Austro-Węgrzech i carskiej Rosji, zaś na terenach dawniej zajmowanych przez Prusy - w oparciu o praktykowany w tym kraju model trójinstancyjny ${ }^{26}$.

W późniejszych latach nastąpiły próby kodyfikacji polskiego prawa administracyjnego. W 1925 roku wydano ustawy o ogólnym postępowaniu administracyjnym, o postępowaniu egzekucyjnym $\mathrm{w}$ administracji, o prawie karno-administracyjnym oraz przepisy wprowadzające ustawy o postępowaniu administracyjnym. Stanowiły wzorzec dla organizującego się sądownictwa administracyjnego w Czechosłowacji w 1928 roku i Jugosławii w 1930 roku $^{27}$. Natomiast w 1928 roku ukazały się rozporządzenia prezydenta RP o postępowaniu administracyjnym, o postępowaniu przymusowym w administracji i o postępowaniu karno-administracyjnym. Wszystkie one były w użyciu w porządku prawnym Polskiej Rzeczypospolitej Ludowej w pierwszych latach jej funkcjonowania ${ }^{28}$. Jednak mimo tego w PRL odrzucono kontrolę administracji poprzez sądownictwo administracyjne. W praktyce oznaczało to, iż

\footnotetext{
${ }^{23}$ H. Izdebski, M. Kulesza, dz. cyt., s. 225.

${ }^{24}$ R. Chrabąszcz, J. Hausner, S. Mazur, dz. cyt., s. 31.

25 J. Zimmermann, dz. cyt., s. 439.

26 J. Malec, D. Malec, dz. cyt., s. 239 i nast.

${ }^{27}$ M. Wierzbowski, M. Szubiakowski, A. Wiktorowska (red.), dz. cyt., s. 5.

${ }^{28}$ Tamże, s. 6.
} 
kontrola taka w ogóle przestała istnieć. Pozytywnymi zmianami było przyjęcie w 1960 roku obowiązującego do dziś Kodeksu postępowania administracyjnego oraz jego kompleksowa nowelizacja z 1980 roku. W tym samym roku uchwalono również ustawę o Naczelnym Sądzie Administracyjnym, która przywróciła sądową kontrolę administracji, na razie w oparciu o enumeratywne wyliczenie spraw, w jakich NSA mógł orzekać, i tylko w trybie jednoinstancyjnym, ale z wydziałami zamiejscowymi w województwach ${ }^{29}$.

Po upadku komunizmu enumeratywne wyliczenie spraw znajdujących się pod jurysdykcją NSA zostało zastąpione klauzulą generalną, zaś konstytucja III Rzeczpospolitej w artykule 175 stanowi, iż wymiar sprawiedliwości w RP stanowią Sąd Najwyższy, sądy powszechne, sądy administracyjne i sądy wojskowe ${ }^{30}$. Prawie siedem lat zajęło polskim władzom stworzenie systemu sądownictwa, o którym mowa w konstytucji z 2 kwietnia 1997 roku. Dopiero w roku 2002 uchwalone zostały ustawy: Prawo o ustroju sądów administracyjnych, Prawo o postępowaniu przed sądami administracyjnymi oraz przepisy wprowadzające Prawo o ustroju sądów administracyjnych i Prawo o postępowaniu przed sądami administracyjnymi. Na ich podstawie od 1 stycznia 2004 roku ukształtowała się w Polsce dwuinstancyjna struktura sądownictwa administracyjnego z działającymi jako pierwsza instancja wojewódzkimi sądami administracyjnymi, które powstały z przekształcenia zamiejscowych ośrodków NSA, oraz Naczelnym Sądem Administracyjnym jako drugą i ostatnią instancją, jednocześnie sprawującą nadzór nad wojewódzkimi sądami administracyjnymi ${ }^{31}$.

Istotę mieszanego modelu sądowej kontroli administracji funkcjonującego w Polsce stanowi fakt, iż kontrolę tę sprawuje obecnie Naczelny Sąd Administracyjny i inne sądy administracyjne, a także, w ograniczonym zakresie i na ściśle określonych zasadach, sądy powszechne ${ }^{32}$. Owa kontrola ze strony sądów powszechnych może przybierać postać bezpośrednią lub pośrednią, obydwie te formy opisał Tadeusz Woś. Pierwsza z nich ma miejsce, gdy na podstawie szczególnego przepisu ustawowego sądy powszechne są upoważnione do rozpoznania skargi albo innego środka zaskarżenia decyzji administracyjnej, co może kończyć się pozbawieniem zaskarżonej decyzji bytu prawnego i wydaniem nowego rozstrzygnięcia. Najczęściej kontrola taka ma miejsce przy rozpoznawaniu spraw z zakresu ubezpieczeń społecznych ${ }^{33}$. W przypadku kontroli pośredniej sąd powszechny nie rozpatruje środków prawnych od decyzji administracyjnych, ale z mocy prawa wiążąco orzeka o prawach i obowiązkach o charakterze cywilnoprawnym, co do których została wcześniej wydana decyzja administracyjna. Konstrukcja tego typu istnieje na przykład w prawie wodnym oraz prawie geodezyjnym i kartograficznym ${ }^{34}$.

\footnotetext{
${ }^{29}$ J. Zimmermann, dz. cyt., s. 440.

${ }^{30}$ Tamże, s. 436.

31 Tamże, s. 441 i nast.

32 T. Woś, H. Knysiak-Molczyk, M. Romańska, dz. cyt., s. 22.

33 Tamże, s. 22.

34 Tamże, s. 24.
} 


\section{Podsumowanie}

Wielość sposobów, w jakich odbywa się sądowa kontrola administracji, jest imponująca. W niniejszym opracowaniu wskazano tylko część z nich, ale są to te rozwiązania, które przez lata stanowiły wzór dla tworzącego się sądownictwa administracyjnego kolejnych państw. Wybitny brytyjski prawnik przełomu XIX i XX wieku Albert V. Dicey twierdził, że prawo administracyjne może występować tylko na kontynencie, zwłaszcza we Francji, jako dowód uprzywilejowania administracji poprzez wyłączenie dotyczących jej spraw spod jurysdykcji sądów powszechnych ${ }^{35}$. Jednak nie z powodu podejścia Brytyjczyków do prawa administracyjnego rozumianego na sposób kontynentalny trudno jest implementować jego rozwiązania na gruncie innych państw, zwłaszcza spoza kręgu common law. W istocie bowiem brytyjski system prawa administracyjnego jest ledwie kiełkujący. Widać jednak, że nawet przedstawiciele kultury prawa precedensowego przyjmują instrumenty sądowej kontroli administracji, co jest widomym znakiem tego, że biorą pod uwagę ewentualność jego istnienia. Spoglądając na kończącą drugi wiek funkcjonowania sądową kontrolę administracji, daje się zauważyć, że najbardziej stabilne rozwiązania w tej dziedzinie zaproponowali Francuzi oraz Niemcy. Ta ocena wynika przede wszystkim z faktu, iż właśnie jeden z tych systemów stał się wzorcem sądownictwa administracyjnego kształtowanego przez poszczególne państwa, na przykład w przypadku Polski wzorcem był system niemiecki. Zarówno ogromnie długa praktyka i doświadczenie sądownictwa francuskiego, jak i precyzja i konsekwencja przepisów niemieckich z pewnością przyczyniają się do dobrej kontroli administracji. Oba te przypadki pokazują też, że prawo administracyjne, podobnie jak każda inna dziedzina funkcjonowania państwa, nie lubi zmian rewolucyjnych i dzięki ich brakowi działa sprawnie, stanowiąc przykład dla innych państw.

Polski system sądownictwa administracyjnego, choć nie oryginalny, jak wspomniano wyżej, był w międzywojniu inspiracją dla systemów Czechosłowacji oraz Jugosławii. Natomiast po latach degradacji w czasach komunistycznych został sprawnie zrekonstruowany. Na uwagę zasługuje tu przede wszystkim wprowadzenie modelu dwuinstancyjnego, który powinien być charakterystyczny dla każdego państwa prawa. Wyjątki, w których w sprawach administracyjnych orzekają sądy powszechne, z pewnością nie sprzyjają spójnemu funkcjonowaniu sądów, zwłaszcza w odbiorze przez obywateli. Nie bez racji byłoby więc zapewne ujednolicenie polskiego sądownictwa administracyjnego. Ma ono jeszcze ciągle sporo luk i nieścisłości, które utrudniają mu prawidłowe funkcjonowanie ${ }^{36}$. Wiele z nich związanych jest z uprawnieniami nadzorczymi organów władzy wykonawczej, które są pozostałościami po epoce PRL. Truizmem jest oczywiście stwierdzenie, że żaden z systemów sądowej kontroli administracji nie jest idealny i każdy ma swoje wady. Nie da się wskazać jednoznacznie, który z systemów sądowej kontroli administracji jest najlepszy, a który funkcjonuje najgorzej. Argumenty za i przeciw każdemu z nich z powodzeniem

${ }^{35}$ H. Izdebski, M. Kulesza, dz. cyt., s. 33.

36 Zob. J. Olech, Ustawa o samorządzie gminnym, powiatowym i wojewódzkim a ustawa Prawo o postępowaniu przed sądami administracyjnymi - rozbieżności i luki prawne, [w:] J. Lewicki, J. Olech (red.), 10 lat reformy samorządowej w Polsce - doświadczenia i wyzwania, Instytut Multimedialny, Kraków 2010, s. 61 i nast. 
mogą stać się przedmiotem osobnego opracowania. Niewątpliwą zdobyczą każdego z nich jest jednak fakt, iż chroni on publiczne prawa podmiotowe. $Z$ punktu widzenia teorii prawa jest to stwierdzenie fundamentalne. Z punktu widzenia tych, którzy na co dzień teorią prawa się nie zajmują, natomiast dość często spotykają się z władczymi aktami administracji, jak na przykład decyzje administracyjne, a więc większości naszej populacji, fundamentalne znaczenie ma fakt istnienia instytucji, w której mogą oni dochodzić swych praw i bronić interesów.

\section{Bibliografia}

Chrabąszcz R., Hausner J., Mazur S., Administracja publiczna w wybranych krajach Europy Środkowo-wschodniej, Wydawnictwo Akademii Ekonomicznej w Krakowie, Kraków 2003.

Izdebski H., Kulesza M., Administracja publiczna-zagadnienia ogólne, Liber, Warszawa 2000.

Lewicki J., Olech J. (red.), 10 lat reformy samorzadowej w Polsce-doświadczenia $i$ wyzwania, Instytut Multimedialny, Kraków 2010.

Malec J., Malec D., Historia administracji i myśli administracyjnej, Wydawnictwo Uniwersytetu Jagiellońskiego, Kraków 2003.

Olech J., Ustawa o samorzadzie gminnym, powiatowym i wojewódzkim a ustawa Prawo o postępowaniu przed sądami administracyjnymi - rozbieżności i luki prawne, [w:] J. Lewicki, J. Olech (red.), 10 lat reformy samorządowej w Polsce - doświadczenia $i$ wyzwania, Instytut Multimedialny, Kraków 2010.

Sarnecki P., Ustroje konstytucyjne państw współczesnych, Zakamycze, Kraków 2004.

Wierzbowski M., Szubiakowski M., Wiktorowska A. (red.), Postepowanie administracyjne, Wydawnictwo C.H. Beck, Warszawa 2006.

Woś T., Knysiak-Molczyk H., Romańska M., Postępowanie sądowo-administracyjne, LexisNexis, Kraków 2004.

Zimmermann J., Prawo administracyjne, Zakamycze, Kraków 2005.

\section{Streszczenie}

\section{Modele sądowej kontroli administracji - próba syntezy}

Artykuł poświęcony jest ukształtowaniu się sądownictwa administracyjnego jako instrumentu kontroli administracji oraz podstawowym modelom sądownictwa administracyjnego. Przedstawia on także ewolucję polskiego systemu sądownictwa administracyjnego i rozwiązania, z jakich czerpało ono na przestrzeni prawie stu lat swego funkcjonowania. Syntetyczne ukazanie modeli ukształtowania sądownictwa administracyjnego oraz sposobów sądowej kontroli administracji ma za cel próbę wskazania najskuteczniejszych rozwiązań w dziedzinie kontroli administracji publicznej.

Słowa kluczowe: administracja, sąd, kontrola, prawo, władza 


\section{Summary}

\section{Models of judiciary control over administration - a synthetic approach}

This article discusses two issues: a) the development of administrative judiciary as an instrument of control over administration; b) basic models of administrative judiciary. We show the evolution of the Polish administrative judiciary, as well as various institutional solutions that inspired it during nearly one hundred years of its functioning. The aim of both the synthetic characterisation of the models of administrative judiciary and the presentation of different forms of judiciary control over administration is to suggest the most efficient solutions concerning control over public administration.

Keywords: administration, court, control, law, authority 
Lilija Twardosz

Uniwersytet Pedagogiczny im. KEN w Krakowie

\section{Wdrożenie przepisów UE dotyczących spraw spadkowych do porządku prawnego Rzeczypospolitej Polskiej}

\section{Wprowadzenie}

Od dnia wejścia Polski do Unii Europejskiej nastąpiła zmiana w hierarchii dotychczas obowiązujących w krajowym porządku prawnym źródeł prawa. Cechą charakterystyczną źródeł prawa Unii Europejskiej jest jego nadrzędność w stosunku do krajowych systemów prawa. Nadrzędność ta przejawia się w bezpośrednim obowiązywaniu, stosowaniu oraz bezpośredniej skuteczności w porządkach krajowych państw członkowskich. Na przestrzeni ostatnich 14 lat polski system prawny przeszedł ogromną transformację w zakresie ujednolicenia krajowych przepisów prawnych z przepisami wspólnotowymi.

Akty prawne Unii Europejskiej tworzone są z myślą o ujednoliceniu porządków prawnych państw członkowskich, na które składają się liczne wielostronne konwencje międzynarodowe lub poszczególne akty prawne odnoszące się do postępowania międzynarodowego. W doktrynie została przyjęta zasada, że źródła prawa możemy podzielić w zasadzie na trzy kategorie, pierwotne, wtórne i źródła tzw. trzeciorzędne. Podział ten zależy przede wszystkim od hierarchii norm, ale również od ich mocy wiążącej. Najczęściej mówimy o rozporządzeniach, dyrektywach, decyzjach, opiniach i zaleceniach.

Polska po tylu latach funkcjonowania we Wspólnocie jako jej pełnoprawny członek bezpośrednio stosuje normy prawa Unii Europejskiej oraz skutecznie ujednolica swój porządek prawny. Organy sprawiedliwości państw członkowskich w zależności od konkretnej sprawy stosują nie tylko swoje przepisy prawne, ale również przepisy Unii Europejskiej. W tym zakresie nastąpiły duże zmiany prawne w porządkach prawnych państw członkowskich. Państwa członkowskie, w tym oczywiście Polska, dokonują transpozycji do swoich porząd- 
ków określonych regulacji prawnych w postaci między innymi rozporządzeń i dyrektyw. Zmiana przepisów krajowych ma polegać na tym, aby cel wskazany w konkretnej dyrektywie został osiągnięty poprzez dostosowanie krajowych norm prawnych. Dyrektywa w relacji do rozporządzenia nie ma bezpośredniej skuteczności. Z punktu widzenia postępowania przed sądami krajowymi ogromne znaczenie mają rozporządzenia. Rozporządzenie UE jest wiążącym aktem prawnym, ma zasięg ogólny i musi byś bezpośrednio stosowane na terytorium każdego państwa członkowskiego. Rozporządzenia mają moc obowiązującą wobec wszystkich państw członkowskich, a ich postanowienia odnoszą się bezpośrednio do osób fizycznych i prawnych będących obywatelami tych państw.

Od dnia wejścia do Unii Europejskiej w roku 2004 kilkunastu nowych państw członkowskich liczba obywateli EU powiększyła się kilkakrotnie. Obywatele państw członkowskich częściej zaczęli przemieszczać się w granicach UE. Tysiące obywateli polskich wyjechało do innych krajów UE z wielu powodów. Dla jednych była to możliwość znalezienia lepiej płatnej pracy, dla innych możliwość podjęcia nauki lub też zwykła ciekawość innych kultur. Większe możliwości w przemieszczaniu się obywateli państw członkowskich w granicach UE spowodowały również powstanie problemu natury cywilistycznej, a konkretnie odpowiedzi na pytanie, co się stanie z majątkiem po śmierci osoby fizycznej niebędącej obywatelem państwa członkowskiego, w którym nastąpił zgon. Jakie są skutki prawne śmierci osoby fizycznej przebywającej w kraju, którego obywatelstwa nie posiada? Przecież śmierć osoby fizycznej nie powoduje utraty należących do niej praw i obowiązków majątkowych, lecz powoduje ich przejście na inne podmioty. W skład spadku po zmarłym wchodzą nie tylko prawa majątkowe, ale również obowiązki majątkowe. Są to prawa rzeczowe i wierzytelności, ale również długi zmarłego. Poza tym należałoby odpowiedzieć na wiele pytań, takich jak: Kto te prawa i obowiązki majątkowe może dziedziczyć i na jakich zasadach? Które prawo będzie w tej sytuacji prawem właściwym: prawo państwa, którego zmarły był obywatelem, czy prawo państwa, gdzie nastąpił zgon? Co się stanie w sytuacji, gdy zmarły w chwili śmierci posiadał obywatelstwo kilku państw? Co się stanie w sytuacji sporządzenia kilku testamentów w różnych państwach członkowskich? Prawo którego państwa członkowskiego będzie właściwe dla wszczęcia postępowania spadkowego? To jest tylko kilka z przykładowych pytań, na które odpowiedzi spowodowały rozpoczęcie prac nad ujednoliceniem prawa spadkowego UE.

Krajowe regulacje spraw spadkowych państw członkowskich różniły się w wielu przypadkach, dlatego też ważnym krokiem na drodze ujednolicenia postępowania spadkowego o charakterze uniwersalnym dla UE było przyjęcie nowych spójnych przepisów unijnych mających na celu uproszczenie formalności prawnych związanych ze spadkami międzynarodowymi. W związku z tym 4 lipca 2012 roku przyjęto Rozporządzenie Parlamentu Europejskiego i Rady (UE) nr 650/2012 w sprawie jurysdykcji, prawa właściwego, uznawania i wykonywania orzeczeń, przyjmowania i wykonywania dokumentów urzędowych dotyczących dziedziczenia oraz w sprawie ustanowienia europejskiego poświadczenia spadkowego (Dz.U. UE L.2012.201.107)ํ․

${ }^{1}$ Dz.Urz. UE L201 z 27.07.2012, s. 107 z późn. zm. 


\section{Rozporządzenie Parlamentu Europejskiego i Rady (UE) nr 650/2012 w sprawie jurysdykcji, prawa właściwego, uznawania i wykonywania orzeczeń, przyjmowania i wykonywania dokumentów urzẹdowych dotyczących dziedziczenia oraz w sprawie ustanowienia europejskiego poświadczenia spadkowego}

\section{Zakres stosowania i jurysdykcja}

Przyjęte w dniu 4 lipca 2012 roku Rozporządzenie Parlamentu Europejskiego i Rady (UE) nr 650/2012 (zwane dalej Rozporządzeniem) umożliwiło prawidłowe funkcjonowanie w europejskiej przestrzeni prawnej rozwiązań prawnych w zakresie spraw spadkowych obywateli wszystkich państw członkowskich. Do dnia wejścia w życie Rozporządzenia ze względu na różnorodność obowiązujących systemów prawnych obywatele państw członkowskich byli ograniczeni w wykonywaniu swoich praw w zakresie spraw spadkowych. Wielu spadkobierców, zapisobiorców lub wierzycieli i innych osób, którym przysługiwało prawo do spadku, nie miało skutecznie zagwarantowanych swoich praw do spadków transgranicznych. Rozporządzenie reguluje przyjęcie składników majątku oraz praw i obowiązków na wypadek śmierci bez względu na podstawę, tj. czy mówimy o dziedziczeniu ustawowym, czy dziedziczeniu na podstawie testamentu².

W uzasadnieniu prawodawca wskazuje, że Rozporządzenie reguluje tylko i wyłącznie materię związaną z jurysdykcją, prawem właściwym, uznawaniem, przyjmowaniem, wykonalnością i wykonywaniem orzeczeń, dokumentów urzędowych i ugód sądowych oraz wprowadza przepisy dotyczące ustanowienia europejskiego poświadczenia spadkowego ${ }^{3}$. Rozporządzenie wyłącza spod swojej jurysdykcji wszystkie sprawy regulujące kwestie administracyjne i podatkowe o charakterze cywilnoprawnym (na przykład sprawy podatkowe związane z dziedziczeniem powinny być regulowane prawem państwa członkowskiego), pomija również kwestie regulujące ustroje majątkowe małżeńskie, kwestie dotyczące tworzenia i rozwiązywania trustó $w^{4}$ oraz zarządzania nimi lub kwestie regulujące przenoszenie praw inaczej niż w drodze dziedziczenia (na przykład darowizny, chyba że odnosi się to do darowizn inter vivos, które zgodnie z prawem właściwym dla dziedziczenia powinny być uwzględnione dla celów ustalenia udziałów w spadku). Z uwagi na różnorodność systemów prawnych państw członkowskich Rozporządzenie przewiduje możliwość dostosowania

${ }^{2}$ Powyższego rozporządzenia nie stosuje się w Danii, Irlandii i Zjednoczonym Królestwie.

${ }^{3}$ Motyw 9 preambuły do Rozporządzenia: „Zakres stosowania niniejszego rozporządzenia powinien obejmować wszystkie cywilnoprawne aspekty dziedziczenia majątku po osobie zmarłej, a mianowicie wszystkie formy przejścia składników majątku, praw i obowiązków na skutek śmierci, czy to na podstawie dobrowolnego rozrządzenia na wypadek śmierci, czy to w drodze dziedziczenia ustawowego".

${ }^{4}$ Trust - umowa, na mocy której jedna osoba przekazuje swój majątek na określony cel (donator), a druga osoba zobowiązuje się zarządzać tymi środkami (trustee) w sposób określony w umowie trustu (ang. deed of trust, pol. umowa powiernicza). Umowa trustu stanowi, że donator przekazuje określone mienie na rzecz trustee, a trustee zobowiązuje się, że będzie zarządzał tym mieniem na korzyść określonych osób (beneficjentów). Zawarcie takiej umowy powoduje, że odpada konieczność przeprowadzenia postępowania spadkowego, gdyż po śmierci ,przekazującego" trustee zobowiązany jest zgodnie z postanowieniami umowy rozporządzić majątkiem zmarłego. 
nieznanego prawa rzeczowego do najbliższego odpowiednika takiego prawa rzeczowego, przewidzianego w prawie innego państwa członkowskiego5.

Na szczególną uwagę zasługują również intencje prawodawcy nakazujące interpretację terminu sąd w sposób rozszerzający. Rozporządzenie traktuje jako sąd również notariuszy i przedstawicieli innych zawodów prawniczych, pod warunkiem że sprawują oni funkcje sądownicze w sprawach spadkowych w danym państwie członkowskim ${ }^{6}$. W Polsce ze względu na szczególną rolę notariusza w sprawach spadkowych (na przykład złożenie u notariusza oświadczenia o przyjęciu lub odrzuceniu spadku, sporządzenie testamentu, sporządzenie protokołów dziedziczenia, protokołów otwarcia i ogłoszenia testamentów oraz aktów poświadczenia dziedziczenia, sporządzenie umów o zrzeczenie się spadku oraz umów działu spadku) wejście w życie Rozporządzenia spowodowało zmianę przepisów prawa o notariacie ${ }^{7}$, na mocy których obecnie notariusz jest upoważniony do sporządzenia europejskiego poświadczenia dziedziczenia ${ }^{8}$. W związku z tym obecnie w Polsce właściwymi organami w sprawach spadkowych są sądy oraz notariusze (w odniesieniu do spraw wskazanych wyżej) ${ }^{9}$. Rozporządzenie dotyczy tylko dziedziczenia i przepisy te mają zastosowanie w przypadku dziedziczenia po osobach zmarłych po dniu 17 sierpnia 2015 roku.

${ }^{5}$ Motyw 17 preambuły do Rozporządzenia: „Dostosowanie nieznanych praw rzeczowych, wyraźnie przewidziane w niniejszym rozporządzeniu, nie powinno wykluczać innych form dostosowania w ramach stosowania niniejszego rozporządzenia”.

${ }^{6}$ Motyw 20 preambuły do Rozporządzenia: „Niniejsze rozporządzenie powinno respektować różne systemy regulujące kwestie dziedziczenia stosowane w państwach członkowskich. Do celów niniejszego rozporządzenia termin są powinien zatem być rozumiany szeroko, tak aby obejmował nie tylko sądy w dosłownym znaczeniu tego słowa, sprawujące funkcje sądownicze, lecz także notariuszy lub urzędy stanu cywilnego w niektórych państwach członkowskich, sprawujące w niektórych sprawach dotyczących spadku funkcje sądownicze, oraz notariuszy i przedstawicieli zawodów prawniczych, którzy w niektórych państwach członkowskich sprawują funkcje sądownicze w danej sprawie spadkowej na podstawie przekazania uprawnień przez sąd. Wszystkie sądy w rozumieniu niniejszego rozporządzenia powinny być związane zasadami jurysdykcji określonymi w niniejszym rozporządzeniu. Natomiast termin sąd nie powinien obejmować organów pozasądowych państwa członkowskiego uprawnionych na mocy prawa krajowego do zajmowania się sprawami spadkowymi, takich jak notariusze w większości państw członkowskich, w których zazwyczaj nie sprawują oni funkcji sądowniczych".

7 Ustawa z dnia 14 lutego 1991 r. Prawo o notariacie, Dz.U. 2013, poz. 237 z późn. zm.

${ }^{8}$ Motyw 21 preambuły do Rozporządzenia: „Niniejsze rozporządzenie powinno umożliwiać wszystkim notariuszom, którzy są właściwi w państwach członkowskich w sprawach spadkowych, wykonywanie tych uprawnień. To, czy notariusze w danym państwie członkowskim są związani zasadami jurysdykcji określonymi w niniejszym rozporządzeniu, powinno zależeć od tego, czy są oni objęci zakresem definicji «sądu» do celów niniejszego rozporządzenia”. Motyw 22 preambuły do Rozporządzenia: „Przepływ aktów sporządzanych przez notariuszy w sprawach spadkowych w państwach członkowskich powinien się odbywać na podstawie niniejszego rozporządzenia. Jeżeli notariusze sprawują funkcje sądownicze, są oni związani zasadami jurysdykcji, a przepływ wydanych przez nich orzeczeń powinien się odbywać zgodnie z przepisami o uznawaniu, wykonalności i wykonywaniu orzeczeń. Jeżeli notariusze nie sprawują funkcji sądowniczych, nie są oni związani zasadami jurysdykcji, a przepływ wydawanych przez nich dokumentów urzędowych powinien być zgodny z przepisami o dokumentach urzędowych”.

9 Art. 95q Prawo o notariacie: „W zakresie nieuregulowanym w rozporządzeniu Parlamentu Europejskiego i Rady (UE) nr 650/2012 z dnia 4 lipca 2012 r. w sprawie jurysdykcji, prawa właściwego, uznawania i wykonywania orzeczeń, przyjmowania i wykonywania dokumentów urzędowych dotyczących dziedziczenia oraz w sprawie ustanowienia europejskiego poświadczenia spadkowego (Dz.Urz. UE L201 z 27.07.2012, s. 107 z późn. zm.) do czynności dotyczących europejskiego poświadczenia spadkowego stosuje się odpowiednio przepisy o sporządzaniu aktu poświadczenia dziedziczenia, chyba że przepisy niniejszego rozdziału stanowią inaczej”. 
Rozporządzenie mówi o jurysdykcji ogólnej, przyjmując, że właściwe będzie to państwo członkowskie, w którym zmarły miał miejsce zwykłego pobytu. Sądy polskie, jak również notariusze, analizując swoją właściwość w konkretnej sprawie spadkowej, najpierw powinni się kierować pojęciem ,miejsce zwykłego pobytu” zmarłego, które w Rozporządzeniu zdefiniowane jest jako wszystkie okoliczności życia zmarłego w latach poprzedzających jego śmierć i w chwili jego śmierci, przy czym bierze się pod uwagę czas trwania i częstotliwość obecności zmarłego w danym państwie, warunki i powody tej obecności. Miejsce zwykłego pobytu powinno wykazywać ścisły i stabilny związek zmarłego z danym państwem. W przypadkach gdy zmarły ze względów ekonomicznych/zawodowych wyjechał z kraju pochodzenia, ale mimo to zachował ścisły i stabilny związek ze swoim państwem pochodzenia, to według Rozporządzenia organ, przed którym rozpatrywana jest sprawa spadkowa, może uznać, że miejsce zwykłego pobytu nadal znajduje się w państwie pochodzenia. W wyjątkowych sytuacjach, gdy zmarły zamieszkiwał kolejno w kilku państwach, nie mieszkając na stałe w żadnym z tych państw, właściwy organ, przed którym toczy się postępowanie, bierze pod uwagę obywatelstwo zmarłego lub bada, w którym z tych państw znajdują się główne składniki jego majątku.

W celu ułatwienia prowadzenia spraw spadkowych Rozporządzenie wprowadza pojęcie umowy prorogacyjnej na rzecz sądów państwa członkowskiego wybranego prawa ${ }^{10}$. Odsyłając do treści art. 22 Rozporządzenia ${ }^{11}$, prawodawca unijny wskazuje jako łącznik podstawowy identyfikujący właściwość państwa członkowskiego łącznik obywatelstwa. Każdy może dokonać wyboru prawa, któremu będzie podlegać dziedziczenie po nim, ale wybór ten ograniczony jest do prawa obywatelstwa. Jeżeli wybór prawa nie został dokonany wcześniej, wówczas sąd/notariusz ma obwiązek zastosować łącznik ,miejsca zwykłego pobytu” zmarłego (przy spełnieniu przewidzianych Rozporządzeniem warunków) ${ }^{12}$. W przypadku braku jurysdykcji krajowej właściwy organ stwierdza z urzędu brak swojej jurysdykcji. Wyjątkową sytuację reguluje art. 11 Rozporządzenia, który stanowi, że sąd może orzec w sprawie spadkowej, gdy żadne z państw członkowskich nie ma jurysdykcji w tej sprawie, ale po spełnieniu dwóch warunków. Po pierwsze, sąd musi stwierdzić, że brak jest jurysdykcji krajowej oraz pozostałych

${ }_{10}$ Art. 5 Rozporządzenia: „1. W przypadku gdy wybrane przez zmarłego prawo regulujące dziedziczenie po nim zgodnie z art. 22 jest prawem państwa członkowskiego, zainteresowane strony mogą umówić się, że wyłączną jurysdykcję do orzekania w sprawie dotyczącej spadku mają sąd lub sądy tego państwa członkowskiego. 2. Taka umowa prorogacyjna sporządzana jest na piśmie, opatrywana datą i podpisywana przez zainteresowane strony. Każde przekazanie informacji za pomocą środków elektronicznych umożliwiające trwały zapis umowy uznaje się za równoważne ze sporządzeniem na piśmie”.

${ }^{11}$ Art.22 Rozporządzenia: „1. Każdy może dokonać wyboru prawa państwa, którego obywatelstwo posiada w chwili dokonywania wyboru lub w chwili śmierci, jako prawa, któremu podlega ogół spraw dotyczących jego spadku. Każdy, kto posiada więcej niż jedno obywatelstwo, może wybrać prawo każdego państwa, którego obywatelstwo posiada w chwili dokonywania wyboru lub w chwili śmierci. 2. Wybór prawa musi być dokonany w sposób wyraźny w oświadczeniu w formie rozrządzenia na wypadek śmierci lub musi wynikać z postanowień takiego rozrządzenia. 3. Ważność materialna aktu, którym dokonano wyboru prawa, podlega wybranemu prawu. 4. Każda zmiana lub odwołanie wyboru prawa musi spełniać wymogi co do formy przewidziane dla zmiany lub odwołania rozrządzenia na wypadek śmierci”.

12 Art.21 Rozporządzenia: „1. Jeżeli przepisy niniejszego rozporządzenia nie stanowią inaczej, prawem właściwym dla ogółu spraw dotyczących spadku jest prawo państwa, w którym zmarły miał miejsce zwykłego pobytu w chwili śmierci. 2. W przypadku gdy wyjątkowo, ze wszystkich okoliczności sprawy jasno wynika, że w chwili śmierci zmarły był w sposób oczywisty bliżej związany z państwem innym niż państwo, którego prawo byłoby właściwe na mocy ust. 1, prawem właściwym dla dziedziczenia jest prawo tego innego państwa". 
państw członkowskich i nie ma możliwości wszczęcia postępowania w państwie trzecim, które jest właściwe w tej sprawie, a po drugie, sprawa spadkowa musi mieć ścisły związek z państwem, przed którym sprawa się toczy ${ }^{13}$. Przy czym sytuacja ta dotyczy tylko i wyłącznie sądów, a nie notariusza, ponieważ notariusz nie posiada tak daleko idących uprawnień. Przepisy prawa o notariacie nie przewidują możliwości dokonania przez notariusza czynności w przypadku stwierdzenia przez niego braku jurysdykcji krajowej ${ }^{14}$.

Jeżeli zmarły uprzednio dokonał wyboru prawa państwa, którego obywatelstwo posiadał w chwili dokonywania wyboru lub w chwili śmierci, właściwy sąd, który wszczął postępowanie spadkowe z urzędu, musi postępowanie umorzyć, jeżeli spadkobiercy uzgodnili, że rozstrzygną sprawę spadkową polubownie poza sądem w państwie członkowskim, którego prawo zostało przez zmarłego wybrane. Na wniosek jednej ze stron sąd, przed którym toczy się postępowanie spadkowe, ma możliwość ograniczenia swojej kognicji do nieorzekania w odniesieniu do jednego składnika majątku zmarłego lub większej ich liczby znajdujących się w państwie trzecim. Sytuacja ta ma miejsce, jeżeli można oczekiwać, że wydane przez sąd prawomocne postanowienie o stwierdzenie nabycia spadku nie będzie uznane lub wykonane w państwie trzecim. Na podstawie przepisów Rozporządzenia w postępowaniu spadkowym obowiązuje zasada zawisłości spraw spadkowych ${ }^{15}$. W przypadku złożenia pozwu w tej samej sprawie spadkowej na przykład najpierw w sądzie w Krakowie, a następnie w sądzie w Berlinie, wyłączona wówczas jest możliwość rozpatrywania tej sprawy przez sąd niemiecki do czasu stwierdzenia jurysdykcji krajowej sądu, przed którym najpierw wszczęto postępowanie spadkowe, tj. sądu w Krakowie. Wówczas sąd niemiecki musi stwierdzić brak swej jurysdykcji na rzecz sądu polskiego. Na wniosek stron sąd polski może orzec o zastosowaniu środków zabezpieczających, przewidzianych w prawie polskim, nawet jeżeli na mocy Rozporządzenia właściwa jurysdykcja w sprawie należy do sądu innego państwa członkowskiego.

\section{Europejskie poświadczenie spadkowe}

Jednym z rozwiązań dotychczas niestosowanym w krajowym porządku prawnym jest możliwość wydania przez sąd lub notariusza europejskiego poświadczenia spadkowego (zwanego dalej EPS).

Rozporządzenie przewiduje uznawanie z mocy prawa orzeczeń w sprawach spadkowych wydawanych w państwach członkowskich, jak i obowiązek przyjmowania dokumentów

13 Art. 11 Rozporządzenia: „W przypadku gdy żaden sąd państwa członkowskiego nie ma jurysdykcji na mocy innych przepisów niniejszego rozporządzenia, sądy państwa członkowskiego mogą, w drodze wyjątku, orzekać w sprawie spadkowej, jeżeli postępowanie nie może być we właściwy sposób wszczęte lub przeprowadzone, lub nie byłoby możliwe w państwie trzecim, z którym sprawa jest ściśle związana. Sprawa musi mieć dostateczny związek z państwem członkowskim sądu, do którego ją wniesiono".

${ }_{14}$ Art. 95e Prawo o notariacie: „§ 1. Po spisaniu protokołu dziedziczenia notariusz sporządza akt poświadczenia dziedziczenia, jeżeli nie ma wątpliwości co do istnienia jurysdykcji krajowej, treści właściwego prawa obcego, osoby spadkobiercy, wysokości udziałów w spadku, a w przypadku gdy spadkodawca uczynił zapis windykacyjny - także co do osoby, na której rzecz spadkodawca uczynił zapis windykacyjny, i przedmiotu zapisu. § 2. Notariusz odmawia sporządzenia aktu poświadczenia dziedziczenia, jeżeli: [...] 4) w sprawie brak jurysdykcji krajowej".

${ }^{15}$ Art. 17 i 18 Rozporządzenia. 
urzędowych wydanych w sprawach spadkowych w tych państwach. Możliwość uzyskania EPS jest fakultatywna i nie zastępuje postanowienia o stwierdzenie nabycia spadku wydanego przez sąd, lub aktu poświadczenia dziedziczenia wydanego przez notariusza. Korzystanie w innych państwach członkowskich z wykazujących sukcesję spadkową orzeczeń i dokumentów urzędowych powinno ułatwiać wydawanie zaświadczeń na formularzach wskazanych w rozporządzeniu wykonawczym 1329/2014 ${ }^{16}$.

EPS może być wykorzystywane przez spadkobierców, zapisobierców oraz wykonawców i zarządców testamentów, którzy potrzebują wykazać w innym państwie członkowskim swój status lub wykonywać swoje prawa bądź swoje uprawnienia. Pod względem proceduralnym regulacja EPS nie jest kompleksowa. Rozporządzenie daje upoważnienie do uregulowania kwestii bardziej szczegółowych krajowym porządkom prawnym państw członkowskich. Wdrożenie regulacji Rozporządzenia do przepisów krajowych spowodowało wprowadzenie do księgi czwartej, części drugiej kodeksu postępowania cywilnego, nowego tytułu VIIA Europejskie poświadczenie spadkowe (art. 1142 11142$)^{17}$. W ustawie Prawo o notariacie dodano nowy rozdział 3 b Europejskie poświadczenie spadkowe, a ponadto uznano, że w postępowaniu przed notariuszem mają zastosowanie również wybrane przepisy kodeksu postępowania cywilnego - art. 670, 672-674 i 676.

Sąd albo notariusz wydają EPS na wniosek spadkobierców, zapisobierców, wykonawców lub zarządców testamentów. Z wnioskiem o wydanie EPS nie mogą wystąpić wierzyciele spadkowi, natomiast zgodnie z art. 70 ust. 1 Rozporządzenia mogą uzyskać odpis już wydanego EPS. Przed wydaniem EPS sąd lub notariusz bada z urzędu, kto jest spadkobiercą i czy został sporządzony testament. Warunkiem wydania EPS jest niesporny charakter sprawy spadkowej ${ }^{18}$.

W przypadku powzięcia informacji o istnieniu testamentu sąd/notariusz wzywa osobę, co do której uprawdopodobniono, że posiada ona testament, do jego złożenia. Jeśli taki testament istnieje, sąd/notariusz dokonuje otwarcia i ogłoszenia testamentu. Sąd/notariusz może przyjąć od wnioskodawcy zapewnienie, że nie ma innych spadkobierców i nie został sporządzony testament, a które będzie uznane za dowód w sprawie. Składający zapewnienie zostaje poinformowany przez sąd/notariusza o skutkach karnych złożenia takiego zapewnienia, gdyż jego złożenie jest równoznaczne ze złożeniem zeznań pod przyrzeczeniem. Organ wydający EPS podejmuje wszelkie niezbędne kroki, by poinformować o złożonym wniosku potencjalne zainteresowane osoby (w Rozporządzeniu „beneficjentów”). W razie potrzeby sąd w celu ustalenia okoliczności, które mają być poświadczone, przesłuchuje każdą zaangażowaną osobę oraz każdego wykonawcę lub zarządcę i zamieszcza ogłoszenia publiczne mające na celu umożliwienie innym ewentualnym beneficjentom zgłoszenie swoich praw.

${ }^{16}$ Rozporządzenie wykonawcze Komisji (UE) nr 1329/2014 z dnia 9 grudnia 2014 r. ustanawiające formularze, o których mowa w rozporządzeniu Parlamentu Europejskiego i Rady (UE) nr 650/2012 w sprawie jurysdykcji, prawa właściwego, uznawania i wykonywania orzeczeń, przyjmowania i wykonywania dokumentów urzędowych dotyczących dziedziczenia oraz w sprawie ustanowienia europejskiego poświadczenia spadkowego (Dz.Urz. UE L2015, nr 142, s. 34).

${ }_{17} \mathrm{~W}$ zakresie, w jakim Rozporządzenie nie reguluje procedury wydawania EPS, odpowiednie zastosowanie znajdą przepisu art. 669-679 kpc regulujące postępowanie o stwierdzenie nabycia spadku, przepisy ogólne dla spraw z zakresu prawa spadkowego art. 627-628 kpc oraz przepisy ogólne o postępowaniu nieprocesowym.

${ }^{18}$ Por. art. 95c $\S 2$ pkt 1 Prawa o notariacie i art. 67 ust. 1 lit. a) Rozporządzenia. 
Właściwy organ wydaje EPS niezwłocznie i z użyciem formularza, który ma charakter obligatoryjny. O wydaniu EPS należy w miarę możliwości poinformować tzw. beneficjentów (art. 67 ust. 2 Rozporządzenia spadkowego). Wydane poświadczenie wywołuje skutki prawne we wszystkich państwach członkowskich i nie wymaga już dodatkowych procedur. Poświadczenie stanowi podstawę wpisu we właściwych rejestrach państwa członkowskiego, w którym będzie ono przedłożone. Sąd/notariusz przechowuje oryginały poświadczeń i wydaje ich poświadczone odpisy wnioskodawcy lub każdemu, kto wykaże uzasadniony interes. EPS przechowywane jest w oryginale przez sąd/notariusza, który wydaje jego poświadczone odpisy. Sąd z urzędu doręcza postanowienie o wydanie EPS wraz poświadczonym odpisem tego poświadczenia i z pouczeniem o przysługujących środkach odwoławczych. Notariusz z urzędu wydaje wypis protokołu obejmującego wydanie lub odmowę wydania EPS w ramach sporządzanych w kancelarii czynności notarialnych wraz z pouczeniem o przysługujących środkach odwoławczych.

W razie uprzedniego wydania EPS nie ma podstaw do sporządzenia aktu poświadczenia dziedziczenia (zwanego dalej APD) albo do występowania z wnioskiem o stwierdzenie nabycia spadku. W takim przypadku sąd/notariusz powinni oddalić wniosek o stwierdzenie nabycia spadku lub odmówić wydania APD. Z kolei nic nie stoi na przeszkodzie, aby wydać EPS po uprzednim uzyskaniu stwierdzenia nabycia spadku czy APD. Tak wydane EPS jedynie uzupełnia wcześniej wydane postanowienie lub APD o skutek transgraniczny.

Wszystkie wydane przez właściwy organ poświadczone odpisy ważne są przez okres 6 miesięcy (w tym celu na odpisie powinna być wskazana data ważności poświadczenia). Wyjątkowo, w uzasadnionych przypadkach, okres ważności poświadczenia może zostać przedłużony, ale po upływie tego okresu należy wystąpić do organu wydającego o jego przedłużenie albo o nowy poświadczony odpis. Wadliwie wydane EPS może zostać sprostowane, zmienione lub uchylone. Sprostowania, zmiany lub uchylenia może dokonać sąd/notariusz wydający EPS na wniosek każdego, kto wykaże swój uzasadniony interes lub z urzędu, w przypadku wystąpienia błędu pisarskiego lub powzięcia przez właściwy organ informacji, że wydane EPS lub jego poszczególne części są nieprawidłowe. O każdej zmianie, sprostowaniu lub uchyleniu sąd/notariusz informuje wszystkie osoby, którym uprzednio było wydane EPS. Każdy, kto jest uprawniony do wystąpienia o wydanie EPS, może odwołać się od decyzji podjętych przez organ wydający (art. 72 Rozporządzenia). Na postanowienie sądu pierwszej instancji przysługuje zażalenie (art. $1142^{6} \mathrm{kpc}$ ). Na czynności notariusza przysługuje zażalenie (art. 95x w związku z art. 83 Prawo o notariacie) ${ }^{19}$.

\footnotetext{
19 Art. 83 § 1. Prawo o notariacie: „Na odmowę dokonania czynności notarialnej osoba zainteresowana może wnieść, w terminie tygodnia od dnia doręczenia uzasadnienia odmowy, a gdy nie zażądała w przepisanym terminie doręczenia uzasadnienia odmowy - od dnia, w którym dowiedziała się o odmowie, zażalenie do sądu okręgowego właściwego ze względu na siedzibę kancelarii notariusza odmawiającego dokonania czynności notarialnej. Zażalenie wnosi się za pośrednictwem tego notariusza. § 1a. Notariusz, o którym mowa w $\S 1$, jest obowiązany ustosunkować się do zażalenia w terminie tygodnia i wraz z zażaleniem przedstawić swoje stanowisko sądowi oraz doręczyć je osobie zainteresowanej, chyba że sporządził i doręczył już tej osobie uzasadnienie odmowy. § 1b. Sąd rozpoznaje zażalenie na rozprawie, stosując odpowiednio przepisy Kodeksu postępowania cywilnego o postępowaniu nieprocesowym. § 2. Notariusz może, jeżeli uzna zażalenie za słuszne, dokonać czynności notarialnej; w tym przypadku nie nadaje zażaleniu dalszego biegu".
} 


\section{Wnioski końcowe}

Wejście w życie Rozporządzenia Parlamentu Europejskiego i Rady (UE) nr 650/2012 w sprawie jurysdykcji, prawa właściwego, uznawania i wykonywania orzeczeń, przyjmowania i wykonywania dokumentów urzędowych dotyczących dziedziczenia oraz w sprawie ustanowienia europejskiego poświadczenia spadkowego uzupełniło krajowy porządek prawny w postępowaniu w sprawach spadkowych o element transgraniczny, jakim jest obecnie europejskie poświadczenie spadkowe. Dokument ten pozwala na szybkie, a przede wszystkim skuteczne załatwianie sprawy spadkowej z elementem transgranicznym. Przepisy UE upraszczają międzynarodowe sprawy spadkowe. Europejskie poświadczenie spadkowe jest instrumentem legitymacyjnym prawa unijnego i służy do wykazania sukcesji spadkowej spadkobierców, zapisobierców, wykonawców testamentu lub zarządców majątku spadkowego, gdy zachodzi konieczność udowodnienia ich praw i uprawnień do spadku w innych państwach członkowskich.

Pod wpływem przyjętych przez prawodawcę unijnego rozwiązań, również polski prawodawca w nowym świetle spojrzał na krajowe instrumenty legitymacyjne. Polska należycie wdrożyła rozwiązania Rozporządzenia. W przepisach krajowych została przewidziana alternatywna ścieżka wobec drogi sądowej, którą jest postępowanie spadkowe z udziałem notariusza. Sądowa i notarialna droga funkcjonują jako równorzędne i niezależne od siebie tryby. Decyzja, która ścieżka zostanie wybrana, zależy od zainteresowanych podmiotów.

Europejskie poświadczenie spadkowe stało się kolejnym dokumentem służącym wykazywaniu praw do spadku (obok postanowienia sądu o stwierdzeniu nabycia spadku i aktu poświadczenia dziedziczenia wydawanego przez notariuszy) i przeznaczone jest na potrzeby wykazywania prawa do spadku za granicą. EPS nie zastępuje postanowienia o stwierdzenie nabycia spadku ani aktu poświadczenia dziedziczenia, lecz stanowi ich alternatywne rozwiązanie. Nie powinno być ono tytułem wykonawczym, lecz powinno mieć skutek dowodowy. Wydane w Polsce EPS jest uznawane we wszystkich państwach członkowskich UE bez żadnych dodatkowych formalności. Wprowadzona nowelizacja prawa spadkowego umożliwiła od dnia 17 sierpnia 2015 roku szybkie załatwianie spraw bez konieczności przeprowadzania żmudnych procedur i ponoszenia dodatkowych kosztów.

\section{Bibliografia}

Kot T., Wejście w życie rozporzadzenia spadkowego - wybrane zmiany w prawie polskim, „Krakowski Przegląd Notarialny" 2016, nr 1.

Margoński M., Charakter prawny europejskiego poświadczenia spadkowego. Analiza prawno-porównawcza aktu poświadczenia dziedziczenia i europejskiego poświadczenia spadkowego, Instytut Wymiaru Sprawiedliwości, Warszawa 2015.

Pisuliński J., Europejskie poświadczenie spadkowe, [w:] M. Pecyna, J. Pisuliński, M. Podrecka (red.), Rozprawy cywilistyczne. Ksiega pamiątkowa dedykowana profesorowi Edwardowi Drozdowi, LexisNexis, Warszawa 2013. 


\begin{abstract}
Akty prawne
Rozporządzenie Parlamentu Europejskiego i Rady (UE) nr 650/2012 w sprawie jurysdykcji, prawa właściwego, uznawania i wykonywania orzeczeń, przyjmowania i wykonywania dokumentów urzędowych dotyczących dziedziczenia oraz w sprawie ustanowienia europejskiego poświadczenia spadkowego, Dz.U. UE L.2012.201.107.
\end{abstract}

Rozporządzenie wykonawcze Komisji (UE) nr 1329/2014 z dnia 9 grudnia 2014 r. ustanawiające formularze, o których mowa w rozporządzeniu Parlamentu Europejskiego i Rady (UE) nr 650/2012 w sprawie jurysdykcji, prawa właściwego, uznawania i wykonywania orzeczeń, przyjmowania i wykonywania dokumentów urzędowych dotyczących dziedziczenia oraz w sprawie ustanowienia europejskiego poświadczenia spadkowego, Dz.Urz. UE L.2015, nr 142.

Ustawa z dnia 17 listopada 1964 r. Kodeks postępowania cywilnego, Dz.U. 2018.0.1360.

Ustawa z dnia 14 lutego 1991 r. Prawo o notariacie, Dz.U. 2013, poz. 237 z późn. zm.

\title{
Streszczenie \\ Wdrożenie przepisów UE dotyczących spraw spadkowych do porządku prawnego Rzeczypospolitej Polskiej
}

Krajowe regulacje spraw spadkowych państw członkowskich różniły się w wielu przypadkach, dlatego też ważnym krokiem na drodze ujednolicenia postępowania spadkowego o charakterze uniwersalnym dla UE było przyjęcie nowych spójnych przepisów unijnych uchwalonych w celu uproszczenia formalności prawnych związanych ze spadkami międzynarodowymi. W tym celu 4 lipca 2012 roku zostało przyjęto Rozporządzenie Parlamentu Europejskiego i Rady (UE) nr 650/2012 w sprawie jurysdykcji, prawa właściwego, uznawania i wykonywania orzeczeń, przyjmowania i wykonywania dokumentów urzędowych dotyczących dziedziczenia oraz w sprawie ustanowienia europejskiego poświadczenia spadkowego. Pod wpływem przyjętych przez prawodawcę unijnego rozwiązań również polski prawodawca w nowym świetle spojrzał na krajowe instrumenty legitymacyjne. W przepisach krajowych została przewidziana alternatywna ścieżka wobec drogi sądowej, którą jest postępowanie spadkowe z udziałem notariusza. Sądowa i notarialna droga funkcjonują jako równorzędne i niezależne od siebie tryby.

Słowa kluczowe: europejskie poświadczenie spadkowe, akt poświadczenia dziedziczenia, notariusz, sąd

\section{Summary \\ The adoption of EU laws regarding inheritance into the law of the Republic of Poland}

The domestic regulations of inheritance in EU member states differs. In order to synchronise inheritance proceedings at the European level new EU laws were passed to simplify the legal issues related to international inheritance. On 4 July 2012 Regulation (EU) No 650/2012 of the European Parliament and of the Council was enacted. Its scope includes matters such as applicable jurisdiction, recognition and enforcement of the inheritance related rulings, and acceptance and application of the inheritance documents 
as well as the creation of a European Certificate of Succession. Under the influence of the solutions adopted by the EU legislator, the Polish legislator looked with a new perspective on national legitimacy instruments in a new light. The existing national law provides an alternative path to the court proceedings, that is, inheritence proceedings involving a public notary, therefore the judicial and notarial way have equal standing and are independent of each other.

Keywords: European attestation of inheritance, act of attestation of inheritance, notary, court 


\section{Kontrola administracji publicznej - ujęcie systemowe (wybrane aspekty)}

\section{Wstẹp}

Kontrola jest właściwością administracji od początku procesu kształtowania się administracji publicznej. Funkcja kontroli w poszczególnych etapach rozwoju administracji miała jednak zróżnicowany wymiar pod względem roli, zakresu treści i celów. Kontrola jest elementem koniecznym organizacji i działania niezależnie od rodzaju podmiotu (społeczny, prywatny czy państwowy). Współcześnie w każdym demokratycznym państwie z funkcjonowaniem władzy publicznej łączy się występowanie kontroli. Administracja odpowiada za stan spraw publicznych, przejawia się w różnorakich dziedzinach życia społecznego, politycznego, gospodarczego czy kulturalnego. Realizacja tak szerokiego zakresu zadań i funkcji musi podlegać ocenie pod kątem skuteczności i efektywności.

Administracja posiada funkcję władczą, na przykład realizowanie praw i interesów jednostki, nakładanie obowiązków, reglamentowanie zachowań społecznych. W przypadku braku kontroli uprawnienie to mogłoby być nadużywane lub wykorzystywane w niewłaściwy sposób. Istnieje wiele przesłanek wskazujących na to, że funkcja kontroli jest nieodłącznym elementem administracji. Jednak ważniejszym zagadnieniem jest pytanie dotyczące znaczenia kontroli w administracji. Przyjmując za paradygmat rozważań tezę, iż rola kontroli w administracji jest istotna, staniemy przed pytaniami badawczymi o to, jak kontrolować, kto powinien kontrolować, jakie są formy, sposoby, rodzaje i środki kontroli administracji.

Zagadnienie kontroli administracji jest przedmiotem wielu międzyobszarowych analiz naukowych. Podstawę wszelkich analiz tworzy jednak normatywny punkt widzenia podjętej tematyki badawczej. Temat kontroli administracji publicznej stanowi potencjał szczegółowej i kompleksowej analizy, której niniejszy artykuł nie wyczerpuje, a jedynie daje podstawę 
kolejnych analiz badawczych. Przedmiotem refleksji są wybrane aspekty i jednocześnie holistyczny obraz problematyki kontroli administracji.

\section{Kryteria kontroli administracji publicznej}

Kryteria kontroli w odniesieniu do administracji mogą być wielorakie. Wynika to ze złożonej struktury administracji publicznej oraz różnorodności zadań wykonywanych przez jej poszczególne podmioty. W zależności od działania administracji wymagają one różnych sposobów obserwacji, analizy i oceny. Kryteria są zależne od przepisów prawnych regulujących kompetencje oraz zadania kontrolerów, te z kolei najczęściej opisują odniesienie, w stosunku do którego zostaje sprawowana kontrola, stanowią o sprawowaniu kontroli „,pod względem czegoś” lub z określonych „,punktów widzenia”. Istnieją również przypadki, kiedy kryteria kontroli w regulacjach prawnych nie są wskazane w ogóle. Są one wówczas ustalane na podstawie przedmiotowego ujęcia zakresu kontroli.

Odniesienie do mierników kontroli w przepisach prawa występuje w Ustawie z dnia 15 lipca 2011 r. o kontroli w administracji rządowej. Ustawa zawiera nie tylko regulacje dotyczące istoty, celów, zasad czy trybu przeprowadzania kontroli, ale również kryteriów kontroli. Zgodnie z art. 3 ust. 1 przeprowadzenie kontroli ma na celu ocenę działalności jednostki kontrolowanej dokonaną na podstawie ustalonego stanu faktycznego przy zastosowaniu przyjętych kryteriów kontroli ${ }^{1}$. Artykuł 4 ustawy określa kryteria kontroli, uszczegółowiając, że jeżeli przepisy szczególne nie stanowią inaczej, kontrolę przeprowadza się pod względem legalności, gospodarności, celowości i rzetelności². Przepisy prawne wskazują również inne kryteria, takie jak: respektowanie praw i interesów jednostki, prawidłowe wykonywanie określonych czynności lub zgodność z polityką rządu.

Jednym z podstawowych kryteriów kontroli administracji publicznej jest legalność. Słownikowe ujęcie terminu definiuje legalność jako zgodność z prawem, posiadanie mocy prawnej, prawność, prawowitość, jawność ${ }^{3}$. Głównym zadaniem kontroli administracji publicznej pod kątem legalności jest weryfikacja przestrzegania przepisów prawnych przez organy administracji. Kryterium to wynika z zasady praworządności - jednej z podstawowych zasad ustrojowych państwa zawartych w Konstytucji RP. Zgodnie z art. 7 wszystkie „organy władzy publicznej działają na podstawie i w granicach prawa”4. Oznacza to, że wszelkie działania organów władzy publicznej (w tym administracji) muszą być zgodne z obecnie obowiązującym porządkiem prawnym. W tym samym artykule Konstytucji RP zawarta została również zasada legalizmu ${ }^{5}$. Kontrola pod względem legalności jest sprawowana $\mathrm{w}$ celu ustalenia, czy dany organ działa zgodnie z zasadą praworządności i legalizmu. Nadrzędność kryterium legalności wynika z kolejności sprawowania kontroli $\mathrm{z}$ danego punktu widzenia. Kontrola sprawowana w zakresie gospodarności, celowości itd.

${ }^{1}$ Ustawa z dnia 15 lipca 2011 r. o kontroli w administracji rządowej, Dz.U. 2011, nr 185, poz. 1092, art. 3 .

2 Tamże, art. 4.

${ }^{3}$ M. Szymczak (red.), Słownik języka polskiego, PWN, Warszawa 1979.

${ }^{4}$ Konstytucja Rzeczypospolitej Polskiej z dnia 2 kwietnia 1997 r., Dz.U. 1997, nr 78, poz. 483, art. 7.

5 E. Ura, E. Ura, Prawo administracyjne, LexisNexis, Warszawa 2006, s. 73-74. 
nie może zostać przeprowadzona przed kontrolą w zakresie legalności. Działalność organu w zakresie celowości musi zostać poprzedzona weryfikacją wykonywanych zadań pod kątem obowiązującego prawa (kontrola pod względem legalności) ${ }^{6}$.

Celowość jest wyznacznikiem oceny działalności podmiotu kontrolowanego pod względem stopnia, w jakim realizowane są cele i zadania mu przypisane oraz stwierdzenia, czy takie cele są pożyteczne, racjonalne i czy przynoszą pożądane rezultaty. Bardziej szczegółowe kryterium rzetelności dotyczy oceny działań podmiotu kontrolowanego w zakresie należytej staranności utrzymywania standardów, reguł i parametrów w wykonywanych zadaniach.

Kontrola sprawowana z punktu widzenia gospodarności ma za zadanie ustalić, czy podmiot kontrolowany dysponuje środkami zarówno finansowymi, jak i materialnymi przeznaczonymi do wykonywania działalności w sposób optymalny. Kryterium gospodarności obejmuje również optymalizację stosowanych zabiegów organizacyjnych i ekonomiczność działania, czyli umiejętność uzyskiwania jak najlepszych efektów przy jak najmniejszych nakładach sił i środków ${ }^{7}$. Dodatkowymi kryteriami kontroli mogą być szybkość i terminowość. Kontrolując szybkość, analizie poddajemy sprawność i bezzwłoczność działania podmiotu kontrolowanego. Natomiast terminowość w odniesieniu do administracji określa sprawdzenie, czy powierzone zadania wykonywane są w odpowiednim okresie czasu, zgodnie z terminami wyznaczonymi na przykład w przepisach kodeksu postępowania administracyjnego.

Wskazane powyżej kryteria są jedynie podstawowymi wyznacznikami, które rzutują na wyniki działalności administracji przy wykonywaniu kontroli ${ }^{8}$. Ze względu na złożoność administracji i różnorodność działań wykonywanych przez jej organy istnieje wiele różnych, bardziej oraz mniej szczegółowych kryteriów, a co za tym idzie - wyodrębniających się dzięki nim rodzajów kontroli. Oprócz kryteriów, według których kontrola powinna być przeprowadzana, istnieją również wyznaczniki prawidłowej kontroli.

Działalność kontrolna sama w sobie także może podlegać ocenie. Prawidłowa kontrola została określona pewnymi cechami, których obecność zapewnia utrzymanie zadowalającego poziomu i jakości realizowanych działań, a w efekcie widoczne rezultaty. Kontrola sprawowana w prawidłowy sposób oraz odpowiadająca wyznaczonym standardom to kontrola oparta na takich cechach, jak: obiektywizm, kompetentność, sprawność i efektywność.

Podstawą zabezpieczenia bezstronności kontroli jest sytuacja, w której organ kontrolujący nie jest powiązany z jednostką kontrolowaną stosunkiem nadzoru, zwłaszcza gdy nie ponosi za jej działalność żadnej odpowiedzialności. „W przypadku gdy taki stosunek zachodzi, organ kontrolujący skłonny będzie unikać formułowania negatywnej oceny, ponieważ sam ponosi także jakąś odpowiedzialność za to choćby, iż nie ujawnił wcześniej zaistniałych nieprawidłowości"9.

Kontrola jak każda inna funkcja powinna być realizowana w sposób kompetentny. Niezbędne jest posiadanie oraz wykorzystywanie przez kontrolera wiedzy merytorycznej

${ }^{6}$ J. Jagielski, Kontrola administracji publicznej, LexisNexis, Warszawa 2007, s. 51.

7 Tamże, s. 52.

${ }^{8}$ E. Ura, E. Ura, dz. cyt., s. 265.

${ }^{9}$ S. Jędrzejewski, H. Nowicki, Kontrola administracji publicznej: kontrola a nadzór, struktura systemu, instytucje, Comer, Torun 1995, s. 30-31. 
w dziedzinie, którą analizuje i ocenia. Cecha kompetentności kontroli zawiera również umiejętność organizacji i przeprowadzenia czynności kontrolnych. Kontroler powinien łączyć posiadanie wiedzy merytorycznej z wykorzystaniem sposobów i metod odpowiednich dla danego rodzaju kontroli.

Sprawność kontroli wiąże się przede wszystkim z problematyką organizacji procesu kontroli. Sprawna kontrola to taka, która możliwie jak najszybciej wykonuje zadania i przeprowadza założone działania kontrolne w rzetelny sposób. Z kolei założeniem efektywności kontroli jest realizacja zadań oraz osiągnięcie wszystkich założonych celów.

\section{Rodzaje kontroli administracji publicznej}

Podziały kontroli mogą być bardziej lub mniej szczegółowe w zależności od kryteriów, według których dokonuje się klasyfikacji. W doktrynie prawa administracyjnego uwzględnia się podział kontroli na podstawie kilku głównych kryteriów.

Tabela 1. Klasyfikacja kontroli

\begin{tabular}{|c|l|l|l|}
\hline \multicolumn{1}{|c|}{ Podział kontroli ze względu na } \\
\hline \multicolumn{1}{|c|}{ zakres kontroli } & \multicolumn{1}{|c|}{ etap kontroli } & \multicolumn{1}{|c|}{$\begin{array}{c}\text { inicjatywa podjęcia } \\
\text { kontroli }\end{array}$} & $\begin{array}{c}\text { usytuowanie organu } \\
\text { kontrolującego względem } \\
\text { kontrolowanego }\end{array}$ \\
\hline $\begin{array}{l}\text { - nieograniczona } \\
\text { - ograniczona }\end{array}$ & $\begin{array}{l}\text { - wstępna } \\
\text { - faktyczna } \\
\text { - następna }\end{array}$ & $\begin{array}{l}\text { - z urzędu } \\
\text { - na wniosek }\end{array}$ & $\begin{array}{l}\text { - zewnętrzna } \\
\text { - wewnętrzna }\end{array}$ \\
\hline
\end{tabular}

Źródło: opracowanie własne na podstawie J. Jagielski, Kontrola administracji publicznej, LexisNexis, Warszawa 2007; E. Ura, E. Ura, Prawo administracyjne, LexisNexis, Warszawa 2006.

Stosując kryterium zakresu kontroli, wyróżnia się kontrolę zupełną i fragmentaryczną. Pierwsza z wymienionych obejmuje całokształt działań podmiotu kontrolowanego. Może być przeprowadzana ze względu na wszystkie możliwe punkty widzenia (legalność, celowość, gospodarność, sposób realizowania zadań itd.). Natomiast podczas kontroli ograniczonej organ dokonujący kontroli nie może objąć całokształtu działań podmiotu kontrolowanego. Zatem będzie sprawować kontrolę tylko według niektórych kryteriów oceny, obejmując jedynie część działalności podmiotu kontrolowanego ${ }^{10}$.

Ze względu na etapy kontroli wyodrębnić można kontrolę wstępną, faktyczną i następną. Kontrola wstępna obowiązuje organ kontrolowany do przedstawienia dokumentacji działania organowi kontrolującemu jeszcze przed jej rozpoczęciem. Tego typu kontrola zapobiega powstaniu błędów lub nadużyć, jednak wydłuża czas podjęcia działań przez podmiot kontrolowany ${ }^{11}$. Szersze zastosowanie posiada kontrola faktyczna, ponieważ jest to kontrola, która towarzyszy procesowi działania i sprawowana jest w czasie funkcjonowania podmiotu kontrolowanego, czyli wykonywania przez niego zadań. Taka kontrola daje możliwość wychwycenia i eliminacji nieprawidłowości na bieżąco. Z kolei kontrola następna wiąże się

\footnotetext{
${ }^{10}$ J. Jagielski, dz. cyt., s. 42.

${ }^{11}$ Z. Leoński, Nauka administracji, C.H. Beck, Warszawa 2010, s. 142.
} 
ze sprawdzaniem i oceną dokonanych już czynności oraz ich efektów. Zaletą tego rodzaju kontroli jest możliwość oceny funkcjonowania podmiotu kontrolowanego z wszechstronnej perspektywy. Pozwala na wnikliwą analizę i wydanie opinii o nieprawidłowościach. Niestety, równocześnie taka kontrola uniemożliwia wykrycie i eliminację błędów na bieżąco, tym samym poprawę działalności w celu uzyskania pożądanego efektu. Rola kontroli następnej polega na ocenie tego, co było, oraz wysunięciu wniosków i uwag do przyszłych działań podmiotu kontrolowanego ${ }^{12}$.

Według kryterium inicjatywy podjęcia kontroli rozróżnia się kontrolę z urzędu oraz kontrolę na wniosek. Kontrola z urzędu oznacza działania realizowane z inicjatywy podmiotu kontrolującego, który zobowiązany jest do ich wykonania przez prawo. Kontrola na wniosek również realizowana jest jako zadanie nałożone na organ kontrolujący przez prawo, ale bodziec do jej podjęcia pochodzi z zewnątrz (właściwy organ, jednostka organizacyjna lub osoba fizyczna) $)^{13}$.

Określenie kontrola administracji publicznej można rozumieć na dwa sposoby: jako kontrolę nad administracją publiczną (zewnętrzna) oraz jako kontrolę sprawowaną przez samą administrację (wewnętrzna). Ze względu na kryterium usytuowania organu kontrolującego względem kontrolowanego rozróżnić można kontrolę zewnętrzną i wewnętrzną. Do sprawowania kontroli zewnętrznej nad administracją publiczną powoływany jest podmiot znajdujący się poza jednostką kontrolowaną. Kontrolę zewnętrzną ujmuje się zazwyczaj jako kontrolę sprawowaną wyłącznie przez organ, który jest całkowicie niezależny od administracji publicznej. Główną zaletą takiej kontroli jest przede wszystkim jej obiektywizm ${ }^{14}$. Jednak im „dalej” znajduje się organ kontrolujący od administracji, tym trudniej jest mu dokładnie ocenić wszystkie elementy działania podmiotu kontrolowanego ${ }^{15}$, co stanowi istotne ograniczenie skuteczności tego rodzaju kontroli. W skład podsystemu kontroli zewnętrznej administracji wchodzą formy kontroli zróżnicowane między innymi ze względu na charakter podmiotu kontrolującego.

\footnotetext{
12 E. Ura, E. Ura, dz. cyt., s. 266.

13 J. Jagielski, dz. cyt., s. 45.

14 Tamże, s. 87.

15 Z. Leoński, dz. cyt., s. 141.
} 


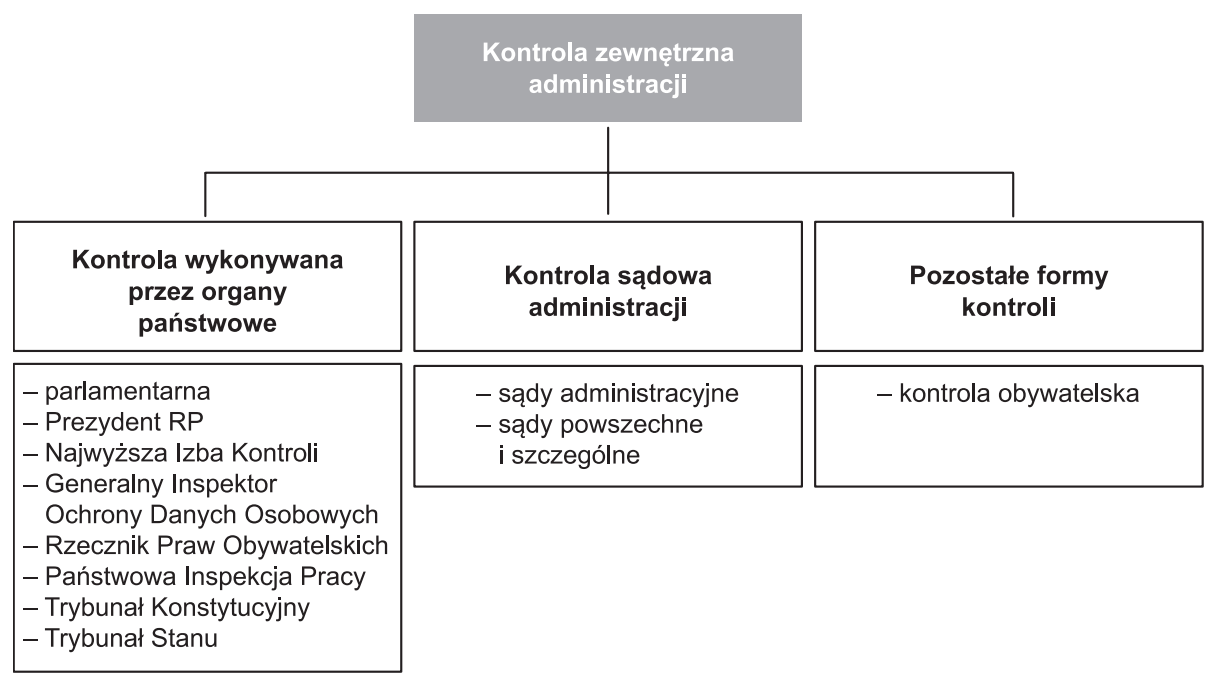

Rysunek 1. Kontrola zewnętrzna administracji

Źródło: opracowanie własne na podstawie J. Jagielski, Kontrola administracji publicznej, LexisNexis, Warszawa 2007; E. Ura, E. Ura, Prawo administracyjne, LexisNexis, Warszawa 2006.

Zgodnie z art. 202 Konstytucji RP Najwyższa Izba Kontroli jest naczelnym organem kontroli państwowej, podległym Sejmowi i działającym w oparciu o zasadę kolegialności. Podstawami prawnymi działania NIK są przepisy Konstytucji Rzeczypospolitej Polskiej z dnia 2 kwietnia 1997 r. (art. 202-207), przepisy zawarte w Ustawie z dnia 23 grudnia 1994 r. o Najwyższej Izbie Kontroli oraz Statut i Zarządzenia Prezesa Izby ${ }^{16}$. Z art. 202 Konstytucji RP wynika, że Najwyższa Izba Kontroli jest wyodrębnionym organem, który w zakresie kontroli państwowej ma dominujące znaczenie względem innych podmiotów. Organem kolegialnym jest Kolegium Najwyższej Izby Kontroli, w skład którego wchodzą: Prezes Najwyższej Izby Kontroli (jako przewodniczący wiceprezesów), dyrektor generalny Najwyższej Izby Kontroli oraz czternastu członków Kolegium (w tym siedmiu przedstawicieli nauk prawnych lub ekonomicznych oraz siedmiu dyrektorów jednostek organizacyjnych NIK lub doradców prezesa $)^{17}$. Prezes kieruje Najwyższą Izbą Kontroli i odpowiada przed Sejmem za działalność Izby ${ }^{18}$. Jest powoływany i odwoływany przez Sejm za zgodą Senatu na okres sześciu lat ${ }^{19}$. Po zasięgnięciu opinii właściwej komisji sejmowej, na wniosek Prezesa Najwyższej Izby Kontroli Marszałek Sejmu powołuje i odwołuje trzech wiceprezesów NIK. Dyrektor generalny Najwyższej Izby Kontroli jest powoływany i odwoływany przez Prezesa Najwyższej Izby Kontroli, za zgodą Marszałka Sejmu ${ }^{20}$. Kadencja członków Kolegium NIK trwa trzy lata. W sprawowaniu swych funkcji są oni niezawiśli. Kolegium

${ }_{16}$ Podstawy prawne działania NIK, https://www.nik.gov.pl/o-nik/podstawy-prawne-dzialania-nik/ [dostęp: 29.04.2018].

${ }^{17}$ Ustawa z dnia 23 grudnia 1994 r. o Najwyższej Izbie Kontroli, Dz.U. 1995, nr 13, poz. 59, art. 22.

18 Tamże, art. 13.

19 Tamże, art. 14-16.

${ }^{20}$ Tamże, art. 21. 
sprawuje funkcję zatwierdzającą, uchwałodawczą i opiniodawczą, a zakres tych czynności został określony w art. 23 ustawy o NIK.

Struktura organizacyjna Najwyższej Izby Kontroli obejmuje siedemnaście departamentów i delegatur. Zgodnie z art. 25 pkt 1a ustawy o NIK departamenty i delegatury są to kontrolne jednostki organizacyjne, które wykonują zadania w zakresie postępowania kontrolnego Najwyższej Izby Kontroli lub wspomagają czynności kontrolne. Departamenty sprawują działalność kontrolną w obrębie danych działów administracji lub gospodarki albo szczególnie istotnego problemu. Są to jednostki organizacyjne o zasięgu ogólnokrajowym, w przeciwieństwie do delegatur (jednostek terenowych kontroli). Realizują zadania wykonawcze i prowadzą kontrolę w sposób skoordynowany z programem opracowanym centralnie lub w ramach planu pracy NIK. Zakres kontroli NIK uwzględniony został w Konstytucji RP oraz doprecyzowany w ustawie o NIK. Przedmiotowy zakres kontroli obejmuje ogół działalności podmiotów kontrolowanych, a w szczególności ich gospodarowanie środkami publicznymi. Podmiotowy zakres kontroli pozwala wyróżnić dwie grupy jednostek poddanych kontroli przez NIK. Art. 203 Konstytucji RP podkreśla, że NIK kontroluje wskazane jednostki państwowe (kontrola obligatoryjna) lub może kontrolować (kontrola fakultatywna) między innymi organy samorządu terytorialnego.

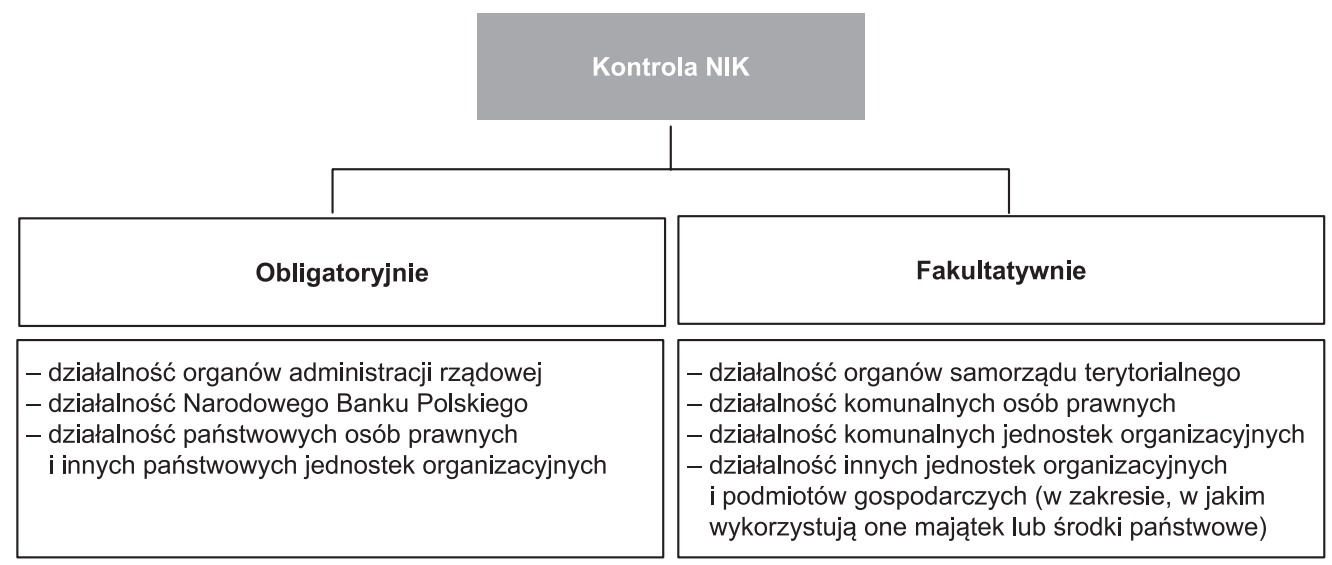

\section{Rysunek 2. Wybrane formy kontroli NIK}

Żródło: opracowanie własne na podstawie J. Jagielski, Kontrola administracji publicznej, LexisNexis, Warszawa 2007; E. Ura, E. Ura, Prawo administracyjne, LexisNexis, Warszawa 2006.

Istotnym zagadnieniem w postępowaniu kontrolnym Najwyższej Izby Kontroli są kryteria, według których oceniana jest działalność podmiotów kontrolowanych. W art. 5 ustawy o NIK wyróżnione zostały kryterium legalności, gospodarności, celowości i rzetelności. Kontrolę działalności samorządu terytorialnego przeprowadza się pod względem legalności, gospodarności i rzetelności. Natomiast kontrolę działalności jednostek organizacyjnych i przedsiębiorców przeprowadza się jedynie w zakresie legalności i gospodarności ${ }^{21}$.

${ }^{21}$ Tamże, art. 5 . 
Tryb postępowania kontrolnego NIK został szczegółowo uregulowany przepisami w art. 27-68 ustawy o NIK. Wyróżnione tam zostały zarówno uprawnienia i obowiązki pracowników NIK, którzy przeprowadzają kontrolę, jak i obowiązki oraz prawa podmiotów kontrolowanych. NIK podejmuje kontrolę na podstawie zleceń Sejmu, jego organów, na wniosek Prezydenta i Prezesa Rady Ministrów lub z własnej inicjatywy. Przeprowadza doraźne kontrole i wykonuje swoje zadania na podstawie corocznego planu pracy, który przedkłada Sejmowi podobnie jak analizę wykonania budżetu państwa i założeń polityki pieniężnej, wszelkie informacje o wynikach kontroli, opinię w przedmiocie absolutorium dla Rady Ministrów oraz wystąpienia ${ }^{22}$.

Podstawą wszystkich form kontroli wewnętrznej jest podporządkowanie organów o niższym stopniu organom wyższego stopnia, które posiadają kompetencje o charakterze kontrolnym wobec podległego im organizacyjnie aparatu. Kontrola wewnątrzadministracyjna jest bardziej rozbudowana. Tworzą ją wszystkie instytucje kontrolne, które są elementami struktury aparatu administracyjnego, a ich funkcje kontrolne obejmują inne jednostki aparatu administracyjnego ${ }^{23}$. Zaletą kontroli wewnętrznej jest to, że organy kontroli lepiej znają materię podmiotów kontrolowanych oraz posiadają możliwość sankcjonowania uchybień. Pojawia się jednak niebezpieczeństwo wartościowania i braku obiektywizmu organów kontrolujących, ponieważ w pewnym stopniu spoczywa na nich odpowiedzialność za wyniki działania kontrolowanych podmiotów ${ }^{24}$.

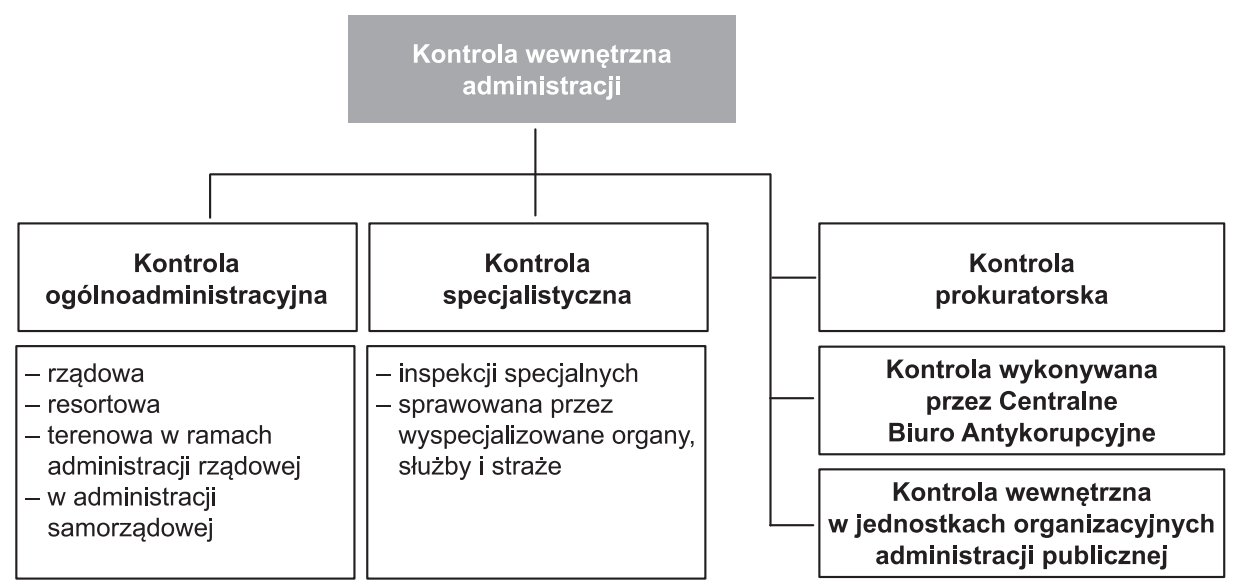

Rysunek 3. Kontrola wewnętrzna administracji

Żródło: opracowanie własne na podstawie J. Jagielski, Kontrola administracji publicznej, LexisNexis, Warszawa 2007.

Kontrola ogólnoadministracyjna zawiera wszelkie procesy administrowania, kierowania i nadzorowania realizowane przez różne podmioty w obrębie aparatu administracyjnego. Ten rodzaj kontroli nie jest wyprofilowany pod konkretnym względem przedmiotowym, nie jest również umiejscowiony w szczególnym układzie organizacyjnym aparatu admini-

\footnotetext{
22 Tamże, art. 7.

23 Z. Leoński, dz. cyt., s. 140.

24 Tamże, s. 141.
} 
stracyjnego. Odnosi się do wieloaspektowego charakteru i ogólnego punktu widzenia przy analizie oraz ocenie działalności administracji publicznej. Kontrolę ogólnoadministracyjną można dostrzec w różnych układach organizacyjnych i segmentach struktury administracji. Skupiając uwagę na podstawowych segmentach administracji publicznej, wyróżniamy: kontrolę rządową, resortową, terenową wykonywaną w ramach administracji rządowej oraz terenową w ramach administracji samorządowej.

Kontrola administracji rządowej bada działalność wszystkich podmiotów wykonujących zadania z zakresu administracji rządowej. Kontroluje przede wszystkim działania organów administracji rządowej oraz organów samorządu terytorialnego i innych podmiotów wykonujących zadania administracji rządowej (w zakresie, w jakim realizują one zadania finansowane z budżetu państwa). Zasady i tryb przeprowadzania kontroli działalności organów administracji rządowej oraz jednostek organizacyjnych im podległych lub przez nie nadzorowanych określa Ustawa z dnia 15 lipca 2011 r. o kontroli w administracji rządowej. Zgodnie $\mathrm{z}$ art. 3 wskazanej ustawy przeprowadzenie kontroli ma na celu nie tylko ocenę działalności jednostki kontrolowanej dokonaną na podstawie ustalonego stanu faktycznego, lecz także w przypadku stwierdzenia nieprawidłowości - ustalenie ich zakresu, przyczyn i skutków oraz osób za nie odpowiedzialnych, a następnie sformułowanie zaleceń zmierzających do usunięcia nieprawidłowości. W świetle art. 4 ustawy kontrolę przeprowadza się pod względem legalności, gospodarności, celowości i rzetelności, jeżeli przepisy szczególne nie stanowią inaczej. Status kierownika jednostki kontrolującej ustawa przypisuje Prezesowi Rady Ministrów, Szefowi Kancelarii Rady Ministrów, ministrom, kierownikom urzędów centralnych, przewodniczącym komitetów wchodzących w skład Rady Ministrów, wojewodom lub osobom, które zgodnie z przepisami określającymi ustrój jednostki są odpowiedzialne za działalność tej jednostki i uprawnione do jej reprezentowania. Prezes Rady Ministrów kontroluje organy i jednostki administracji rządowej oraz jednostki podległe im lub przez nie nadzorowane ${ }^{25}$. Jako organ właściwy w sprawach koordynowania kontroli, w tym zarządzanej przez inne organy administracji rządowej, może: 1) zlecić kierownikowi jednostki kontrolującej przeprowadzenie kontroli wskazanych podmiotów lub obszarów działalności i żądać przedstawiania informacji o wynikach kontroli, 2) delegować kontrolera Kancelarii Prezesa Rady Ministrów do uczestniczenia w kontroli, 3) określić standardy kontroli w administracji rządowej, które udostępnia się w Biuletynie Informacji Publicznej Kancelarii Prezesa Rady Ministrów ${ }^{26}$.

Szef Kancelarii Prezesa Rady Ministrów wykonuje zadania Prezesa Rady Ministrów, które wynikają z ustawy, z upoważnienia Prezesa Rady Ministrów oraz kontroluje instytucje gospodarki budżetowej przez niego utworzone i podmioty, które otrzymały dotację z części budżetu państwa, której dysponentem jest Kancelaria Prezesa Rady Ministrów ${ }^{27}$. Z kolei minister, kierownik urzędu centralnego lub przewodniczący komitetu wchodzącego w skład Rady Ministrów sprawuje kontrolę nad: podległymi mu lub nadzorowanymi przez niego organami i jednostkami organizacyjnymi, jednostkami podległymi tym organom

${ }^{25}$ Ustawa z dnia 15 lipca 2011 r. o kontroli w administracji rządowej, Dz.U. 2011, nr 185, poz. 1092, art. 6 .

${ }^{26}$ Tamże, art. 8.

27 Tamże, art. 6-7. 
oraz podmiotami, które otrzymały środki budżetowe z części budżetu państwa, której jest dysponentem.

Wojewodzie przysługują kompetencje kontrolne wobec: organów rządowej administracji zespolonej w województwie, jednostek podległych tym organom, organów samorządu terytorialnego oraz podmiotów, które otrzymały dotację z części budżetu państwa, której dysponentem jest wojewoda.

Organy administracji zespolonej i niezespolonej kontrolują natomiast podległe im lub przez nie nadzorowane organy lub jednostki organizacyjne i jednostki podległe tym organom lub przez nie nadzorowane.

Wyróżnia się dwa tryby, według których przeprowadzana jest kontrola: zwykły i uproszczony $^{28}$. Etapy i działania kontrolne dla obu trybów szczegółowo określają przepisy zawarte w rozdziale 2 i 3 ustawy. Kontrolę prowadzi się zgodnie z okresowym planem kontroli opracowanym przez kierownika komórki do spraw kontroli i zatwierdzonym przez kierownika jednostki kontrolującej. Kierownik jednostki kontrolującej może jednak zarządzić przeprowadzenie kontroli, która nie jest przewidziana okresowym planem kontroli ${ }^{29}$.

Bardziej skonkretyzowaną formą kontroli administracji jest kontrola resortowa, której źródłem jest występowanie podziału administracji na działy (resorty). Kontrola tego typu sprawowana jest w granicach jednego działu administracji rządowej. Resort oznacza w tym przypadku zhierarchizowany układ organów i jednostek organizacyjnych (zarówno centralnych, jak i terenowych), podporządkowanych określonemu organowi centralnemu. Kontrola realizowana jest nie tylko przez kierownika działu, czyli ministra, lub innego organu naczelnego, ale również występuje między podmiotami umiejscowionymi na niższych szczeblach struktury resortowej. Zasadnicze kompetencje kontrolne przypadają organom stojącym na czele danego resortu (ministrom). Zgodnie z art. 34 ustawy o Radzie Ministrów: minister kieruje, nadzoruje i kontroluje działalność podporządkowanych organów, urzędów i jedno$\operatorname{stek}^{30}$. Jednak kontrola wykonywana jest też przez uprawnionych do tego pracowników lub kierowników wewnętrznych jednostek organizacyjnych (na przykład kierownicy komórek kadrowych, główni księgowi lub dyrektorzy wydziałów). W resortach mogą występować stanowiska lub jednostki utworzone jedynie do sprawowania kontroli, między innymi inspektor kontroli, departament kontroli, wydział inspekcji. Głównym zadaniem kontroli resortowej jest zapewnienie odpowiedniego funkcjonowania struktur administracyjnych, a także ich poszczególnych ogniw. Dlatego tak ważnym elementem tej formy kontroli jest systematyczność. Szczególnym rodzajem kontroli resortowej w zakresie procedury administracyjnej jest kontrola instancyjna. Często wiąże się ona z wykonywaniem funkcji nadzoru, ponieważ organ, który dokonuje kontroli może zmienić rozstrzygnięcia organu niższego stopnia. Kontrola instancyjna dokonywana jest przed organem odwoławczym uruchamianym na skutek odwołania, zażalenia lub w sytuacjach skargi. Celem tej kontroli jest ochrona prawnego interesu strony, która została poddana władczym aktom organu administracji.

Kontrolę między resortami należy rozpatrywać w dwóch płaszczyznach: ze względu na podległość organizacyjną centralnemu lub naczelnemu organowi administracji rządowej

\footnotetext{
${ }^{28}$ Tamże, art. 11.

29 Tamże, art. 12.

${ }^{30}$ Ustawa z dnia 8 sierpnia 1996 r. o Radzie Ministrów, Dz.U. 1996, nr 106, poz. 492, art. 34.
} 
(inspekcja resortowa) oraz ze względu na zasięg kontroli (inspekcje międzyresortowe). Ponadto inspekcje międzyresortowe dzielą się na dwie grupy: o ograniczonym zakresie oraz o pełnym zakresie międzyresortowym. Do grupy o pełnym zakresie międzyresortowej kontroli należy między innymi Państwowa Inspekcja Sanitarna. Podlega ona ministrowi właściwemu do spraw zdrowia i sprawuje nadzór nad warunkami higieny pracy, środowiska, zdrowotności, żywności oraz żywienia. Inspektorzy sanitarni dysponują prawem wstępu o dowolnej porze dnia i nocy do zakładów pracy, obiektów handlowych lub użyteczności publicznej. Organizację pracy oraz zadania Państwowej Inspekcji Sanitarnej określa ustawa.

Przykładem kontroli o pełnym, międzyresortowym zakresie jest również kontrola skarbowa. W tym przypadku organami kontrolnymi są: minister właściwy do spraw finansów, Generalny Inspektor Kontroli Skarbowej oraz dyrektorzy urzędów kontroli skarbowej. Kontrola tego typu dotyczy wszystkich płatników, podatników, izb oraz urzędów skarbowych. Do grupy kontroli o pełnym zakresie należą również: Inspekcja Handlowa, Inspekcja Ochrony Środowiska, Inspekcja Weterynaryjna. Natomiast do grupy inspekcji o ograniczonym zakresie międzyresortowym należy na przykład Państwowa Inspekcja Ochrony Roślin i Nasiennictwa. Zakres kontroli międzyresortowej jest rozbudowany i zróżnicowany w zakresie kompetencji oraz uprawnień poszczególnych organów kontroli ${ }^{31}$.

$\mathrm{Na}$ system administracji publicznej w terenie składają się dwie płaszczyzny: administracja rządowa i administracja samorządowa. Tworzą one odrębne, niezależne od siebie układy organizacyjne, ale pozostają w relacjach nadzoru, współpracy oraz współdziałania. Do struktury administracji rządowej w terenie należą wojewoda oraz kierownicy zespolonych służb, straży i inspekcji pod jego zwierzchnictwem. Zgodnie z art. 28 pkt 1 Ustawy z dnia 23 stycznia 2009 r. o wojewodzie i administracji rządowej w województwie wojewoda kontroluje: 1) wykonywanie przez organy rządowej administracji zespolonej w województwie zadań wynikających z ustaw i innych aktów prawnych wydanych na podstawie upoważnień w nich zawartych, ustaleń Rady Ministrów oraz wytycznych i poleceń Prezesa Rady Ministrów, 2) wykonywanie przez organy samorządu terytorialnego i inne podmioty zadań z zakresu administracji rządowej, realizowanych przez nie na podstawie ustawy lub porozumienia z organami administracji rządowej. W świetle art. 3 pkt 2 ustawy wojewoda kontroluje pod względem legalności, gospodarności i rzetelności wykonywanie przez organy samorządu terytorialnego zadań z zakresu administracji rządowej, realizowanych przez nie na podstawie ustawy lub porozumienia z organami administracji rządowej.

W przypadku kontroli sprawowanej w ramach administracji samorządowej można wyróżnić dwie sfery kontroli: zewnętrzną i wewnętrzną. Pierwsza dotyczy kontroli sprawowanej nad samorządem w ramach nadzoru spoza struktury samorządowej. Natomiast druga sfera określa kontrolę występującą w obrębie struktury samorządowej ${ }^{32}$. Nadzór nad samorządem województwa sprawuje Prezes Rady Ministrów, wojewoda oraz Regionalna Izba Obrachunkowa (w zakresie spraw finansowych). Organy nadzoru posiadają prawo żądania informacji i danych o organizacji i funkcjonowaniu województwa, niezbędnych do wykonywania przysługujących im uprawnień nadzorczych ${ }^{33}$. Organy nadzoru mogą wkra-

\footnotetext{
31 E. Ura, E. Ura, dz. cyt., s. 288-291.

32 J. Jagielski, dz. cyt., s. 184-189.

33 Ustawa z dnia 5 czerwca 1998 r. o samorządzie województwa, Dz.U. 1998, nr 91, poz. 576, art. 80.
} 
czać w działalność województwa jedynie w przypadkach określonych ustawą ${ }^{34}$. W świetle art. 79 ustawy o samorządzie nadzór nad wykonywaniem zadań województwa jest sprawowany na podstawie kryterium zgodności z prawem. Podstawowym środkiem nadzoru stosowanym wobec samorządu województwa i wynikającym z powyższego artykułu jest uchylenie uchwały organu samorządu województwa ze względu na jej sprzeczność z prawem. Ustawa przewiduje również inne środki nadzoru: rozwiązanie sejmiku województwa lub zarządu województwa, zawieszenie organów samorządu województwa i ustanowienie zarządu komisarycznego itp. (art. 84-85). Zastosowanie wymienionych środków ma miejsce jedynie w sytuacjach określonych w przepisach ustawy. Kwestie nadzoru nad samorządem powiatowym i samorządem gminnym nie odbiegają od regulacji dotyczących samorządu województwa ${ }^{35}$.

W ramach zewnętrznej kontroli nad samorządem terytorialnym istotną rolę odgrywają regionalne izby obrachunkowe. Według ustawy z dnia 7 października 1992 r. o regionalnych izbach obrachunkowych są to państwowe organy nadzoru i kontroli gospodarki finansowej. Izby sprawują nadzór nad działalnością jednostek samorządu terytorialnego w zakresie spraw finansowych oraz dokonują kontroli gospodarki finansowej i zamówień publicznych jednostek samorządu terytorialnego, związków i stowarzyszeń powiatów, stowarzyszeń gmin oraz stowarzyszeń gmin i powiatów, związków międzygminnych, samorządowych jednostek organizacyjnych ${ }^{36}$. Kontrola wykonywana przez regionalne izby obrachunkowe odbywa się na podstawie kryterium zgodności z prawem i zgodności dokumentacji ze stanem faktycznym, uwzględniane jest również kryterium celowości, rzetelności i gospodarności ${ }^{37}$. Wewnętrzna sfera kontroli samorządu terytorialnego obejmuje funkcje kontrolne sprawowane w obrębie poszczególnych jednostek samorządu, czyli gminy, powiatu i województwa. Realizowane są pomiędzy organami administracji samorządowej oraz podmiotami samorządowymi o innym statusie prawnym. Funkcję kontrolną spełniają głównie rady samorządowe, tj. rada gminy, rada powiatu oraz sejmik województwa. Są one zarówno organami stanowiącymi, jak i kontrolnymi samorządu terytorialnego, kontrolują działania organów wykonawczych i jednostek organizacyjnych w zakresie określonym przepisami ustawy. Oprócz tego powoływana jest przez każdą radę samorządową i każdy sejmik komisja rewizyjna. Jej zadaniem jest rozpatrywanie oraz opiniowanie budżetu, a także występowanie do rady (sejmiku) z wnioskiem o udzielenie lub nieudzielenie zarządowi absolutorium. Powoływane są również stałe lub doraźne komisje w celu wykonania określonych zadań. W obrębie jednostki samorządowej funkcje kontrolne pełnią również organy wykonawcze, czyli zarząd, wójt, burmistrz lub prezydent. Zakres ich kontroli obejmuje działalność samorządowych jednostek organizacyjnych ${ }^{38}$.

\footnotetext{
${ }^{34}$ Tamże, art. 78.

${ }^{35}$ Kwestie nadzoru zostały uregulowane w ustawach: o samorządzie powiatowym oraz o samorządzie

${ }^{36}$ Ustawa z dnia 7 października 1992 r. o regionalnych izbach obrachunkowych, Dz.U. 1992, nr 85,

37 Tamże, art. 5

38 J. Jagielski, dz. cyt., s. 184-189.
} gminnym. poz. 428 , art. 1 . 


\section{Zakończenie}

Kontrolę administracji realizuje wiele różnych instytucji, klasyfikowanych ze względu na specyfikę prawną i organizacyjną, zakres i metody działania lub przyznane im kompetencje. Wśród podmiotów kontrolujących można wyróżnić organy i jednostki specjalnie powołane do wykonywania kontroli. Istotnym elementem systemu kontroli, warunkującym jego skuteczność jest jednak każde działanie obywatela, organizacji lub grupy społecznej, które zmierza do zwrócenia uwagi na niedoskonałości w funkcjonowaniu organów administracji ${ }^{39}$.

Opisując system kontroli sprawowanej przez administrację, nie można jednoznacznie sprecyzować jego elementów. Składniki tego systemu w większości podlegają regulacji prawnej, jednak jego struktura składa się z wielu podmiotów objętych kontrolą, które należy definiować ze względu na zróżnicowane kryteria. Podstawowym celem kontroli administracji jest nie tylko monitorowanie stanu oraz funkcjonowania administracji, ale także dążenie do poprawy jej działalności poprzez diagnozowanie i niwelowanie błędów oraz ich źródeł. Kontrola powinna zapewniać pewne standardy, szczególnie w strefie kontaktów z obywatelami ${ }^{40}$. Konkludując, należy stwierdzić, iż celem podstawowym kontroli jest porównanie istniejącego stanu faktycznego ze stanem pożądanym. Wszelkie różnice pomiędzy tymi stanami powinny być wykryte przez organ kontrolujący, a sposoby i wskazówki mające zniwelować te niedociągnięcia powinny zostać wskazane w zaleceniach i wnioskach. Funkcjonowanie administracji publicznej jest zatem ściśle związane z jej kontrolą. Obecność kontroli w demokratycznym państwie prawa jest niezbędna ze względu na jej kluczową rolę w ulepszaniu funkcjonowania administracji publicznej. Ze względu na szeroki zakres pojęcia kontrola administracji publicznej jest procesem systemowym. Dla podniesienia efektywności funkcjonowania administracji publicznej konieczne jest ciągłe monitorowanie i uskutecznianie systemu kontroli, którego integralną częścią są obywatele.

\section{Bibliografia}

Bolek T., Dobruk M., Ustawa o kontroli w administracji rzadowej. Komentarz z wzorami dokumentów, Wolters Kluwer, Warszawa 2018.

Jagielski J., Kontrola administracji publicznej, LexisNexis, Warszawa 2007.

Jędrzejewski S., Nowicki H., Kontrola administracji publicznej, Comer, Toruń 1995.

Lang J., Kontrola administracji, [w:] M. Wierzbowski (red.), Prawo administracyjne, LexisNexis, Warszawa 2001.

Leoński Z., Nauka administracji, C.H. Beck, Warszawa 2010.

Podstawy prawne działania NIK, https://www.nik.gov.pl/o-nik/podstawy-prawne-dzialania-nik/ [dostęp: 29.04.2018].

${ }^{39}$ M. Stahl (red.), Prawo administracyjne. Pojęcia, instytucje, zasady w teorii i orzecznictwie, Wolters Kluwer, Warszawa 2013, s. 537-538.

${ }^{40}$ J. Jagielski, dz. cyt., s. 78-85. 
Stahl M. (red.), Prawo administracyjne. Pojęcia, instytucje, zasady w teorii i orzecznictwie, Wolters Kluwer, Warszawa 2013.

Szymczak M. (red.), Słownik języka polskiego, PWN, Warszawa 1979.

Ura E., Ura E., Prawo administracyjne, LexisNexis, Warszawa 2006.

\section{Akty prawne}

Konstytucja Rzeczypospolitej Polskiej z dnia 2 kwietnia 1997 r., Dz.U. 1997, nr 78, poz. 483.

Ustawa z dnia 8 marca 1990 r. o samorządzie gminnym, Dz.U. 1990, nr 16, poz. 95.

Ustawa z dnia 7 października 1992 r. o regionalnych izbach obrachunkowych, Dz.U. 1992, nr 85, poz. 428 .

Ustawa z dnia 23 grudnia 1994 r. o Najwyższej Izbie Kontroli, Dz.U. 1995, nr 13, poz. 59.

Ustawa z dnia 8 sierpnia 1996 r. o Radzie Ministrów, Dz.U. 1996, nr 106, poz. 492.

Ustawa z dnia 5 czerwca 1998 r. o samorządzie powiatowym, Dz.U. 1998, nr 91, poz. 578.

Ustawa z dnia 5 czerwca 1998 r. o samorządzie województwa, Dz.U. 1998, nr 91, poz. 576.

Ustawa z dnia 15 lipca 2011 r. o kontroli w administracji rządowej, Dz.U. 2011, nr 185, poz. 1092.

\section{Streszczenie}

\section{Kontrola administracji publicznej - ujęcie systemowe (wybrane aspekty)}

Artykuł podejmuje problematykę funkcjonowania wybranych elementów systemu kontroli administracji publicznej w Polsce. Wyjaśnia pojęcie kontroli, określa podmiot i przedmiot kontroli. W artykule wskazano wybrane instytucje w polskim systemie prawnym zajmujące się kontrolą, dokonano podziału i klasyfikacji kontroli. Celem artykułu jest uświadomienie funkcji kontroli w kontekście skuteczności działania administracji publicznej. Skoncentrowano uwage jedynie na wybranych podmiotach i narzędziach kontroli oraz wynikających z tego implikacji dla funkcjonowania systemu administracji w Polsce.

Słowa kluczowe: administracja publiczna, kontrola, system, instytucja

\section{Summary}

\section{Public administration control - system approach (selected aspects)}

This article describes the problem of the functioning of selected elements of the public administration control system in Poland. The article explains the concept of control and determines the subject of control. The article indicates selected institutions in the Polish legal system that deal with control, and the division and classification of control. The aim of the article is to show the control function in the context of the effectiveness of public administration. Attention is focused only on selected entities and control tools as well as on the resulting implications for the functioning of the administration system in Poland.

Keywords: public administration, control, system, institution 


\section{Zarządzanie w sektorze publicznym - wybrane zagadnienia}

\section{Wprowadzenie}

Jednym z głównych celów transformacji systemowej w Polsce stała się decentralizacja władzy i administracji, urzeczywistniona w postaci restytucji samorządu terytorialnego i zmienionych ram działania na obszarze terytorialnym. Reforma zarządzania jednostkami lokalnymi stała się przyczynkiem do dalszej decentralizacji dokonanej w 1998 roku na poziomie powiatowym i wojewódzkim. Reformy samorządowe zmieniły funkcjonowanie podziału administracyjnego kraju. Stał się on jednym z podstawowych atrybutów działania zdecentralizowanej administracji publicznej, stanowiąc jednocześnie, szczególnie na poziomie lokalnym, przestrzenne ramy funkcjonowania gospodarki, życia społecznego i aktywności obywatelskiej mieszkańców. Tym samym podniosły się także oczekiwania wobec administracji publicznej, co rodzi konieczność stałego podnoszenia efektywności zarządzania publicznego, między innymi poprzez racjonalizację struktur terytorialnych, odpowiadających zmieniającym się układom przestrzenno-funkcjonalnym ${ }^{1}$. Co za tym idzie - w procesie przemian wprowadzonych przez reformę oraz w ciągu lat wdrażania funduszy strukturalnych zmieniła się nie tylko struktura organizacyjno-prawna działania polskich samorządów. Zmiana ta miała również ogromne znaczenie w procesie myślenia i definiowania samorządu. Władze niejako zostały zmuszone do spojrzenia na jednostkę samorządu terytorialnego jak na ogromny mechanizm - organizację, która jest odpowiedzialna za życie społeczne i gospodarcze członków wspólnoty.

${ }^{1}$ T. Kaczmarek, Gminny podziat administracyjny w świetle 25 lat funkcjonowania samorząu terytorialnego w Polsce, „Przegląd Politologiczny” 2016, R. 21, nr 1, s. 63. 


\section{Czynniki wpływające na zarządzanie strategiczne}

Za czynniki przesądzające o prawidłowości przeprowadzenia reformy uznaje się te, które oddziałują na społeczeństwo, politykę i rozwój ekonomiczny².

Reforma administracji publicznej, ustalona na poziomie prawnym w 1998 roku i wprowadzona w życie 1 stycznia 1999 roku, miała dla urządzenia państwa zasadniczy charakter. W istocie na nowo ukształtowała ona ustrój terytorialny Polski. Decyzje podjęte w 1998 roku określiły system terytorialny na wiele lat. Po pierwsze, został on oparty na zasadzie samorządności terytorialnej. Po drugie, powstały zdefiniowane trzy segmenty władzy publicznej. Po trzecie, w polski system prawny wprowadzona została zasada odpowiedzialności władz terytorialnych za efekty działania aparatu państwowego. Po czwarte, wprowadzono zasady podziału kompetencji w państwie i zdecentralizowano znaczącą część zadań publicznych ${ }^{3}$. Te cztery zasady zapoczątkowały absolutnie nowy rozdział w życiu polskiej administracji - dały samorządowi ogromy zasób możliwości, ale i odpowiedzialności. Wydaje się jednak, patrząc na lata 2002-2018, gdzie samorządy były jednym z bardziej aktywnych beneficjentów funduszy strukturalnych, iż reforma administracyjna była naturalnym etapem procesu demokratyzacji i decentralizacji.

Najważniejsze przyczyny podjęcia reform i rozwoju nowego zarządzania publicznego można pogrupować w trzy podstawowe kategorie:

- rozrost sektora publicznego,

- $\quad$ kryzys gospodarczy i polityczny,

- $\quad$ kryzys wartości tradycyjnej administracji publicznej ${ }^{4}$.

Tabela 1. Najważniejsze obszary reform z punktu widzenia zarządzania strategicznego

\begin{tabular}{|l|l|l|}
\hline \multicolumn{1}{|c|}{ Obszar } & \multicolumn{1}{|c|}{ Charakterystyka } & \multicolumn{1}{|c|}{ Komentarz } \\
\hline $\begin{array}{l}\text { decentralizacja polityczna } \\
\text { i zadaniowa }\end{array}$ & $\begin{array}{l}\text { przesuwanie zadań na niższe szczeble, } \\
\text { włączanie w procesy zadaniowe organizacji } \\
\text { spoza sektora publicznego }\end{array}$ & $\begin{array}{l}\text { naturalny proces zwiększania uprawnień } \\
\text { administracji samorzadowej, podnoszenie } \\
\text { świadomości społecznej }\end{array}$ \\
\hline zmiana zasad finansowych & $\begin{array}{l}\text { realizacja działań w okresie wieloletnim, } \\
\text { planowanie działań w kontekście pozyski- } \\
\text { wania środków zewnętrznych }\end{array}$ & $\begin{array}{l}\text { dostosowanie finansów do nowych realiów, } \\
\text { np. fundusze europejskie, zamówienia } \\
\text { publiczne, pomoc publiczna }\end{array}$ \\
\hline zarządzanie & $\begin{array}{l}\text { nowe formy zarządzania: zarządzanie } \\
\text { strategiczne, zmiany w strukturach orga- } \\
\text { nizacyjnych, dostosowywanie procesów } \\
\text { decyzyjnych do potrzeb organizacji }\end{array}$ & $\begin{array}{l}\text { nastawienie na efekty, rezultaty - myślenie } \\
\text { zadaniowe, myślenie projektowe }\end{array}$ \\
\hline $\begin{array}{l}\text { zarządzanie zasobami } \\
\text { ludzkimi }\end{array}$ & $\begin{array}{l}\text { inwestycje w kadry, profesjonalizacja, } \\
\text { działania etyczne }\end{array}$ & $\begin{array}{l}\text { w wyniku wielu zmian organizacyjno- } \\
\text {-prawnych w celu zachowania konkurencyj- } \\
\text { ności jednostki samorządu terytorialnego } \\
\text { stanęły przed wymogiem zatrudnienia } \\
\text { profesjonalistów - sytuacja była dodatkowo } \\
\text { komfortowa, ponieważ istniała możliwość } \\
\text { finansowania wynagrodzeń i szkoleń } \\
\text { ze środków zewnętrznych }\end{array}$ \\
\hline
\end{tabular}

Źródło: opracowanie własne na podstawie M. Zawicki, Nowe zarzadzanie publiczne, PWE, Warszawa 2011, s. 51-53; K. Marchewka-Bartkowiak, Nowe zarządzanie publiczne, „Infos” 2014, nr 18(178); R.H. Wilson, P.M. Ward, P.K. Spink, V.E. Rodriguez, Governance in the Americas: Decentralization, Democracy and Subnational Government in Brazil, Mexico and the USA, University of Notre Dame Press, Notre Dame 2016.

2 J. Boć, J. Jeżewski (red.), Administracja publiczna, Kolonia Limited, Wrocław 2004, s. 168.

3 J. Kraś, Reforma samorządu terytorialnego jako jeden z kluczowych elementów reformy administracji publicznej w III RP, ,,Resovia Sacra. Studia Teologiczno-Filozoficzne Diecezji Rzeszowskiej”2006, nr 13, s. 291-310.

${ }^{4}$ M. Zawicki, Nowe zarządzanie publiczne, PWE, Warszawa 2011. 
Planowanie i zarządzanie strategiczne stało się jakby elementem szerszej układanki jednoczesne wdrażanie zmian prawnych, organizacyjnych i mentalnych wymusiło niejako działania w obszarze zarządzania. Koncepcja New Public Management (nowe zarządzanie publiczne) była coraz szerzej dyskutowana na forum polskiej nauki i coraz mocniej przenikała w działania polskiej administracji. Myślą przewodnią nowego zarządzania publicznego jest przedkładanie w sprawowaniu administracji publicznej sztuki zarządzania nad sztukę administrowania ${ }^{5}$, co trafnie oddaje O.E. Huges: ,administrowanie oznacza wypełnianie


opiera się zatem na zmianie orientacji zarządzania organizacjami publicznymi polegającej na zaprzestaniu stosowania podejścia stawiającego na piedestale procedury i zasady postępowania związane z dokonywaniem wydatków, a wdrożeniu reguł opartych na analizie osiąganych wyników związanych z ponoszonymi wydatkami, przyjęciu orientacji strategicznej oraz wprowadzeniu mechanizmu rynkowego do procesu świadczenia usług publicznych. Nowe zarządzanie publiczne zwiększa nacisk na jakość dostarczanych usług publicznych zorientowanych na potrzeby i oczekiwania obywatela, który jest traktowany jak ,klient administracji”"

\section{Źródła zarządzania strategicznego gminą}

Pojęcie rozwoju społeczno-gospodarczego składa się z dwóch komponentów. Posługując się tym pojęciem, sygnalizujemy, że rozwój społeczny warunkuje rozwój gospodarczy i odwrotnie. Bez jednego nie będzie drugiego, ale też oba komponenty współtworzą mechanizm napędzający „koło rozwoju”. Podkreślamy przez to, iż warunkowanie się obu podstawowych komponentów rozwoju jest istotne w długiej perspektywie ${ }^{8}$. Przez rozwój będziemy rozumieli jedynie takie zmiany w życiu ekonomicznym, które nie są mu narzucone z zewnątrz, lecz powstają z jego własnej inicjatywy, od wewnątrz'. W takich oto realiach samorząd dostaje nowe zadania, nowe możliwości i kierunki rozwoju. Zaczyna występować w charakterze koordynatora wszelkich działań podejmowanych na obszarze gminy, w tym także działań, których bezpośrednim efektem jest lokalny rozwój gospodarczy ${ }^{10}$.

5 J. Hausner, Zarzadzanie publiczne, Scholar, Warszawa 2008, s. 23 za: E. Młodzik, Założenia koncepcji New Public Management, „Współczesne Problemy Ekonomiczne” 2015, nr 11, s. 185-189.

${ }^{6}$ O.E. Huges, Public Management and Administration. An Introduction, The Macmillan Press Ltd., London 1994, s. 39 za: E. Młodzik, dz. cyt., s. 185-189.

7 E. Młodzik, dz. cyt., s. 185-189.

8 J. Górniak, S. Mazur (red. nauk.), Zarządzanie strategiczne rozwojem, Ministerstwo Rozwoju Regionalnego, Warszawa 2012.

9 J. Schumpeter, Teoria rozwoju gospodarczego, PWN, Warszawa 1960.

${ }^{10} \mathrm{~K}$. Babuchowska, R. Kisiel, Wptyw samorządu gminnego na lokalny rozwój gospodarczy na przykładzie gmin województwa warmińsko-mazurskiego, „Acta Scientiarum Polonorum. Oeconomia” 2006, R. 5, z. 2, http://acta_oeconomia.sggw.pl/pdf/ASO 5 22_2006.pdf [dostęp: 8.03.2019]. 
Sektor publiczny stanowi zatem ten obszar funkcjonowania państwa, w którym wytwarzane są dobra publiczne. W. Kieżun wyraźnie podkreśla, że w polskiej literaturze przedmiotu nie występuje jednolicie zdefiniowane pojęcie tego sektora ${ }^{11}$.

Realizacją zadań z obszaru administracji było wprowadzanie metod planowania i zarządzania strategicznego (wieloletniego). Dzieje się to tak, że JST (tj. jednostki samorządu terytorialnego) powołują jednostki organizacyjne odpowiedzialne za opracowanie strategii.

Dokumentami podstawowymi, na bazie których określony został strategiczny model rozwoju kraju, były Założenia systemu zarządzania rozwojem Polski oraz Plan uporządkowania strategii rozwoju przyjęte przez Radę Ministrów w 2009 roku ${ }^{12}$. Uzupełnieniem tych dokumentów są strategie i plany w różnych obszarach zadaniowych. Zgodnie z art. 24 ustawy o samorządzie terytorialnym realizacja zadań publicznych nakłada na pracowników jednostek samorządu terytorialnego określone obowiązki, do których należy między innymi dbałość o wykonywanie zadań publicznych oraz o środki publiczne z uwzględnieniem interesów państwa i interesów obywateli. Wymóg wykonywania zadań „sumiennie, sprawnie i bezstronnie" zobowiązuje pracowników samorządowych z jednej strony do zachowania wysokich standardów etycznych, z drugiej zaś do posiadania wysokich kompetencji urzędniczych i kwalifikacji merytorycznych. Konieczność zatrudniania pracowników samorządowych o wysokich kwalifikacjach oraz potrzeba stałego podnoszenia ich umiejętności została podkreślona również w Europejskiej Karcie Samorządu Lokalnego (EKSL) ${ }^{13}$.

Zanim doszło do ratyfikacji Karty, Polska wyznaczyła w rozwiązaniach konstytucyjnych i ustawowych zasady samorządności terytorialnej, a w regulacjach szczegółowych ujęto problemy ustroju gminy, ochronę jej samodzielności prawnej czy sytuację majątkową (finansową). Rozwiązania te były zgodne z treścią odpowiednich regulacji EKSL, co charakteryzowano jako przejaw wprowadzania do prawa polskiego wartości ukształtowanych w Karcie. Polska ratyfikowała Kartę, przyjmując za wiążące nie tylko postanowienia wskazane w art. 12, który wyznacza minimalny zakres związania państwa ratyfikującego konwencję Rady Europy - uznała wszystkie artykuły Karty za źródło powszechnie obowiązującego prawa. Stanowisko Polski jest oceniane niezmiennie jako pozytywny przykład reakcji państwa na wyzwania, które wyznacza zaliczenie samorządu terytorialnego do instytucji znamiennych dla systemu ustrojowego ${ }^{14}$.

W pierwszym ustępie art. 3 EKSL zamieszczono definicję legalną samorządu lokalnego rozumianego jako prawo i zdolność społeczności lokalnych, w granicach określonych prawem, do kierowania i zarządzania zasadniczą częścią spraw publicznych na ich własną odpowiedzialność i w interesie ich mieszkańców. Zdolność rozumiana jest jako stan faktyczny, możność warunkowana czynnikami pozaprawnymi, którymi mogą być czynniki ekonomiczne, społeczne, geograficzne. Formuła zasadnicza część spraw publicznych

${ }^{11}$ M. Marks-Krzyszkowska, Zarzadzanie publiczne - istota $i$ wybrane koncepcje, „Acta Universitatis Lodziensis Folia Sociologica" 2016, nr 56, s. 39.

${ }_{12}$ M. Jasińska, Wybrane obszary nowego zarzadzania publicznego w sektorze samorzadowym $w$ Polsce, „Zeszyty Naukowe Politechniki Częstochowskiej. Zarządzanie” 2015, nr 18, s. 69-81, http://www. zim.pcz.pl/znwz [dostęp: 8.03.2019].

13 Tamże, s. 69-81.

${ }^{14}$ L. Kieres, Europejska karta samorzadu lokalnego w orzecznictwie Trybunału Konstytucyjnego, „Ruch Prawniczy, Ekonomiczny i Socjologiczny” 2015, R. LXXVII, z. 3, s. 80-84. 
wyraża wcześniej wspomnianą zasadę subsydiarności, a także zakazuje odbierania lub przyznawania kompetencji samorządom lokalnym w taki sposób, aby ich udział i znaczenie W całości spraw publicznych były marginalne. W kontekście tejże definicji legalnej jako istotny należy wskazać art. 16 Konstytucji RP oraz art. 1 ust. 1 Ustawy z dnia 8 marca 1990 r. o samorządzie gminnym stypulujący, iż ,mieszkańcy gminy tworzą z mocy prawa wspólnotę samorządową” oraz art. 2 ust. 2 nadający gminie osobowość prawną. Pracownicy samorządowi według Karty powinni być wysoko wykwalifikowani, przyjmując kryterium umiejętności i kompetencji, odpowiednio wynagradzani, szkoleni oraz awansowani. Oczywiste jest, iż tak istotne kwestie polski ustawodawca reguluje w ustawie, w tym wypadku w ustawie o pracownikach samorządowych ${ }^{15}$.

\section{Zarządzanie w polskich gminach}

We współczesnej metodyce zarządzania rozwojem organizacji zaleca się stosowanie koncepcji zarządzania strategicznego, które winno być silnie powiązane z działaniami marketingowymi. W myśl tej koncepcji zarządzanie strategiczne jest przemyślanym, perspektywicznie zaplanowanym, skutecznie zorganizowanym i efektywnie realizowanym oraz stale kontrolowanym procesem formułowania i wdrażania strategii rozwoju organizacji. Koncepcja ta skupia uwagę zarządzających organizacją na jak najlepszym wykorzystaniu własnych walorów i zasobów w długookresowej perspektywie. Chodzi tu o rozwój własnego (endogenicznego) potencjału. Rozwój gminy ma charakter wieloaspektowy. Składa się on bowiem z wielu zdarzeń, zjawisk i procesów zaliczanych do różnych sfer (dziedzin) życia społeczności lokalnej. Oznacza to, że nie powinny być one rozpatrywane oddzielnie, samoistnie, lecz przeciwnie - właśnie w ścisłych współzależnościach, zachodzących między nimi i mających charakter przyczynowo-skutkowy, przestrzenny bądź strukturalno-funkcjonalny. Stąd też rozwój gminy winien dokonywać się równocześnie i harmonijnie w sferze: społecznej, kulturowej, gospodarczej, przestrzennej i przyrodniczej. Jest on niezbędnym warunkiem wzrostu:

a) atrakcyjności lokalizacyjnej (inwestycyjnej) oraz rangi gminy w otoczeniu, a w konsekwencji wzrostu liczby mieszkańców, podmiotów gospodarczych i turystów - czynnik ten często determinuje na starcie możliwości rozwojowe gminy; im mniej atrakcyjne położenie gminy, nazwijmy je geopolitycznym, tym bardziej precyzyjna i zindywidualizowana powinna być strategia zarządzania jej zasobami;

b) zatrudnienia i spadku rozmiarów bezrobocia - kapitał ludzki w gminie jest jednym z największych zasobów i im lepsza jego struktura i jakość, tym większe prawdopodobieństwo stworzenia i zrealizowania lepszej strategii;

15 P. Teklak, Obowiązywanie, wyktadnia oraz realizacja przepisów Europejskiej Karty Samorzadu Lokalnego w polskim porządku prawnym, Uniwersytet Wrocławski, Studenckie Koło Naukowe Prawa Międzynarodowego i Europejskiego, s. 96-104, http://www.bibliotekacyfrowa.pl/Content/42873/07 Piotr_Tetlak.pdf [dostęp: 8.03.2019]. 
c) dochodów indywidualnych mieszkańców i dochodów budżetu gminy, a w konsekwencji wzrostu jakości życia mieszkańców wskutek coraz lepszego zaspokajania ich zbiorowych potrzeb.

W rozwoju lokalnym uczestniczy zbiór współzależnych podmiotów gospodarujących, działających na terenie określonej gminy, z których każdy spełnia określone funkcje i dąży do realizacji własnych - często partykularnych - celów. Są to: gospodarstwa domowe i gospodarstwa rolne, jednostki gospodarcze (produkcyjno-usługowe), różnego rodzaju instytucje, organizacje pozarządowe oraz gminne władze samorządowe. Podmioty te tworzą lokalny system gospodarowania ${ }^{16}$.

M. Ziółkowski w swoich rozważaniach wyszczególnił następujące style zarządzania w polskim samorządzie, które, jak sądzę, są pełnym i szerokim spektrum stylów polskiego zarządzania gminnego:

Metoda 1. „Działanie od budżetu do budżetu”, czyli bieżące administrowanie polega na koncentrowaniu się władz gminnych, pod wpływem istniejących trudności, na sprawach doraźnych i fragmentarycznych. Działają one zachowawczo, intuicyjnie, brak sukcesów zaś usprawiedliwiają niekorzystnymi okolicznościami zewnętrznymi.

Metoda 2. „Działanie kadencyjne” to metoda, która koncentruje się na rozwiązywaniu problemów rozwojowych gminy w horyzoncie jednej (czteroletniej) kadencji władz gminy, w myśl wyznawanej przez jej członków zasady: „nasza kadencja jest najważniejsza, kolejne kadencje są zbyt odległe, aby o nich myśleć".

Metoda 3. „Działanie życzeniowe” to metoda rozwiązywania problemów polegająca na tym, że władze gminy dostrzegają konieczność kształtowania procesów rozwojowych w długim okresie (kilku następnych kadencjach). Opracowują one stosowne dokumenty (strategie rozwoju, programy i plany działania). Jednak ich podstawowym mankamentem jest to, że zawierają zbyt wiele celów i przedsięwzięć realizacyjnych w stosunku do możliwości ich sfinansowania zarówno z własnych środków (budżetu gminy), jak i zewnętrznych źródeł finansowania (znane są autorowi przypadki miast, w których koszt przewidzianych do realizacji zadań inwestycyjnych kształtował się na poziomie 5-7 budżetów).

Metoda 4. „Działanie strategiczne” jest metodą zarządzania, polegającą na kształtowaniu procesów rozwojowych gminy i rozwiązywaniu zdefiniowanych problemów w długim horyzoncie czasu (kilkunastoletnia perspektywa). Działania w tym względzie nie są prostą kompilacją rocznych czy też kadencyjnych (czteroletnich) planów działania, znajdujących swe odzwierciedlenie w corocznie uchwalanych budżetach, lecz wynikają z ustaleń perspektywicznych, a co najważniejsze - są skorelowane z możliwościami ich sfinansowania zarówno ze środków własnych, jak i zewnętrznych.

Metoda 5. „Działanie strategiczno-marketingowe”. To najbardziej pożądana metoda zarządzania rozwojem gminy w warunkach gospodarki rynkowej i narastającej konkurencji międzygminnej, jest to przede wszystkim „walka” o kapitał (prywatny i publiczny), tylko bowiem kompleksowe (zintegrowane) podejście do zagadnień z tym związanych daje większą gwarancję odniesienia sukcesu na tym polu ${ }^{17}$. Działania strategiczne i marketingowe dają

\footnotetext{
${ }^{16}$ M. Ziółkowski, Strategiczne zarządzanie rozwojem gminy, „Ruch Prawniczy, Ekonomiczny i Socjologiczny” 2015, R. LXXVII, z. 1.

17 Tamże, s. 149-151.
} 
poniekąd gwarancję na wnikliwą i profesjonalną analizę zasobów jednostki. Pozwalają one również na użycie szerokiego aspektu partycypacyjnego - włączenie mieszkańców i interesariuszy w proces planowania. Jest to jeden z efektów delegowania działań zarządczych na coraz niższe szczeble.

Decentralizacja samorządowa oznacza więc stan rzeczywistej, ujętej w treści norm prawnych sytuacji samorządu terytorialnego oraz jego jednostek. Sytuację tę wyznaczają wartości szczególne: szeroka autonomia kompetencyjna, samodzielność co do wyboru form wykonywania uprawnień oraz środków niezbędnych do realizacji zadań ${ }^{18}$.

Zarządzanie publiczne wyróżnia interwencja zarządcza władzy publicznej, obejmująca: - administrowanie, czyli regulowanie spraw bieżących, wykonywanie czynności zarządu, - $\quad$ wykonywanie obowiązków właścicielskich: nabywanie, zbywanie, fuzje,

- alokację środków publicznych będących w dyspozycji władz publicznych,

- monitoring i ewaluację funkcjonowania jednostki.

Modele zarządzania publicznego wykształciły się w odpowiedzi na wyzwania, jakie przyniosły procesy reformowania zarządzania publicznego. Procesy te implikują ekonomiczne aspekty wydatkowania publicznych środków finansowych na poprawę jakości usług publicznych oraz zapewnienie większej skuteczności działań organizacji publicznych ${ }^{19}$.

Zarządzanie gminą jest rozumiane jako wiedza i umiejętności sterowania zasobami (ludzkimi, finansowymi, przestrzennymi i przyrodniczymi) oraz procesami rozwojowymi w celu ich optymalnego wykorzystania do osiągnięcia zamierzonego celu, jakim jest poprawa warunków życia ludności w istniejących ramowych warunkach działania, tkwiących zarówno w otoczeniu (szanse i zagrożenia rozwoju), jak i wewnątrz gminy (silne i słabe strony) $)^{20}$.

Opracowanie strategii wynika z: konieczności wyznaczenia jednolitego drogowskazu, kierunku rozwoju, konieczności optymalnego wydatkowania środków publicznych na rozwój, potrzeby wskazania podstawy ubiegania się o środki finansowe pochodzące ze źródeł zewnętrznych (np. środki Unii Europejskiej i innych instytucji wspierających rozwój lokalny). Opracowana strategia rozwoju obejmuje wieloletni horyzont czasowy i dlatego powinna być aktualizowana. Jest to podyktowane koniecznością dostosowania strategii do zmieniających się warunków otoczenia, a także do wprowadzonych zmian w narodowym planie rozwoju, w narodowych strategiach rozwoju (np. transportu, rozwoju regionalnego, kultury) czy w innych dokumentach ponadlokalnych. Podczas formułowania strategii poszczególne jednostki samorządu terytorialnego korzystają z pomocy bądź konsultacji ekspertów, mieszkańców i innych interesariuszy. W formułowaniu strategii wykształciły się następujące podejścia: eksperckie, społeczne, partycypacyjne. Wdrożenie strategii rozwoju wydaje się zdecydowanie trudniejsze niż opracowanie założeń strategicznych. Niemniej jednak sam etap planowania strategicznego musi również być prawidłowo przeprowadzo-

${ }^{18}$ L. Kieres, dz. cyt., s. 85.

19 M. Grzebyk, P. Filip, Rola zarządzania w funkcjonowaniu samorządu gminnego, „Nierówności Społeczne a Wzrost Gospodarczy” 2012, z. 29, s. 183-190.

${ }^{20}$ Tamże za: M. Ziółkowski, M. Goleń, Zarządzanie strategiczne rozwojem lokalnym, [w:] H. Sochacka-Krysiak (red.), Zarzadzanie gospodarka i finansami gminy, Wydawnictwo SGH, Warszawa 2006, s. 71-72; M. Ziółkowski, Zarzadzanie strategiczne w polskim samorządzie terytorialnym, [w:] A. Zalewski (red.), Nowe zarządzanie w polskim samorzadzie terytorialnym, Wydawnictwo SGH, Warszawa 2005. 
ny przy współudziale różnych grup i społeczności lokalnej, aby ustrzec się problemów na etapie wdrożenia ${ }^{21}$.

Zarządzanie strategiczne na poziomie gminnym, powiatowym i wojewódzkim widoczne jest w różnych działaniach, jednak przy analizie planowania długookresowego możemy zauważyć następujące etapy, które poniekąd wskazują na posiadanie planu strategicznego w jednostce samorządu:

1. Ustalenie wizji i miejsca określającego kierunek, w jakim samorząd powinien zmierzać.

2. Analiza konkurencyjności - w przypadku samorządu jest to analiza szans i zagrożeń, możliwości i zasobów. Samorząd jest jednostką konkurencyjną, bowiem „,konkuruje” w przypadku aplikowania o środki zewnętrzne na realizację różnego rodzaju projektów i inwestycji. Zagadnienie konkurencyjności samorządu terytorialnego jest zagadnieniem istotnym nie tylko z punktu widzenia analiz ekonomicznych, ale również z uwagi na jej znaczenie dla polityki makroekonomicznej państwa. Istnieje bowiem silna korelacja między efektywnością funkcjonowania na poziomie regionalnym i lokalnym a efektywnością w realizowaniu funkcji publicznych przez państwo, na przykład podział funkcji i zadań, powiązania istniejące pomiędzy budżetem centralnym a budżetami lokalnymi. Konkurencyjność samorządu terytorialnego postrzegana jest w kontekście umiejętności adaptowania przez nie pozytywnych trendów pojawiających się w otoczeniu, kreujących dla nich korzyści wewnętrzne i zewnętrzne, na przykład rozwój przedsiębiorczości. Konkurencyjność jednostki samorządu terytorialnego oznacza jego zdolność, mierzoną w odniesieniu do innych jednostek samorządu terytorialnego, do zagwarantowania społecznego i ekonomicznego otoczenia wspierającego działalność gospodarczą oraz proces podnoszenia ogólnego poziomu produktywności i innowacyjności wykorzystujących wewnętrzne i zewnętrzne zasoby ludzkie, finansowe oraz materialne. Równolegle do powyższej definicji konkurencyjność jednostki samorządu terytorialnego utożsamiano z jej głównymi determinantami: poziomem aktywności gospodarczej, rynkiem pracy i kapitałem ludzkim, dostępnością przestrzenną i teleinformatyczną, przedsiębiorczością i innowacyjnościąa22.

3. Analizuje się własne zasoby i umiejętności, aby na tej podstawie ustalić potencjał doskonałym przykładem w tym zakresie są Gminne Programy Rewitalizacji. Rewitalizacja, stanowiąca zasadniczo zadanie publiczne, prowadzona ma być nie tylko przez podmioty publiczne, lecz także przez interesariuszy tego procesu. Deklaracja ta podkreśla złożoność procesu rewitalizacji, który dla pełnego powodzenia wymaga zaangażowania nie tylko odpowiednich władz publicznych, ale też innych osób i podmiotów. Ustawa przewiduje określone przesłanki dokonywania przewidzianych w niej czynności. Przykładowo: wyznaczenie obszaru zdegradowanego nie może stanowić dowolnej decyzji gminy, lecz wykonanie przepisów ustawy, które określają kryteria wyznaczenia tego obszaru (art. 9). Do podjęcia szeregu rozstrzygnięć wynikających

${ }^{21}$ A. Musioł-Urbańczyk, Metody wspomagajace implementacje strategii rozwoju jednostki samorządu terytorialnego, „Zeszyty Naukowe Politechniki Śląskiej. Organizacja i Zarządzanie” 2015, z. 78, nr 1928, s. 294-299.

22 J. Żbikowski, Konkurencyjność jednostek samorzadu terytorialnego. Wybrane problemy, „Handel Wewnętrzny" 2015, nr 4(357), s. 37-44. 
z ustawy niezbędne jest zatem opracowanie diagnoz, które mają potwierdzać spełnienie określonych przesłanek ustawowych. Gmina ${ }^{23}$ zachowuje swobodę w działaniach wynikających z ustawy, jednak muszą one pozostawać w zgodności z jej regulacjami badanie tej zgodności jest właśnie zadaniem diagnoz.

4. Kreuje się warunki i zasoby umożliwiające podejmowanie działań w celu wykorzystania wyłaniających się sposobności do osiągania sukcesów.

5. Dokonuje się wyboru najkorzystniejszych strategii, projektów, planów - programów.

6. Ustala się właściwe sposoby implementowania ${ }^{24}$.

Zarządzanie w gminie ma charakter interdyscyplinarny i jest procesem złożonym, co wynika zarówno ze specyfiki samych struktur samorządowych, jak i z ustawowych obowiązków, które nakładają na gminę zadania w dziedzinie zaspokojenia potrzeb zbiorowych mieszkańców oraz rozwiązywania bieżących problemów społeczności lokalnych. Sukces każdej organizacji jest uzależniony między innymi od sprawnego nią zarządzania, umożliwiającego skuteczne realizowanie wytyczonych celów. Zarządzanie gminą powinno być efektywne i skuteczne, aby sprostać rosnącym oczekiwaniom społecznym. Pojawiła się konieczność poszukiwania nowych metod zarządzania gminą w celu pobudzania rozwoju lokalnego. Większą uwagę zwraca się na potrzebę współdziałania społeczności lokalnej, władzy lokalnej oraz pozostałych podmiotów funkcjonujących na terenie gminy w zakresie tworzenia korzystnych warunków dla rozwoju lokalnej gospodarki, kreowania nowych i poprawy istniejących walorów gminy ${ }^{25}$. Zarządzanie samo w sobie jest narzędziem prowadzącym do osiągania celów, pobudzania jednostek do działania i realizowania zadań własnych i zleconych. W ciągu ostatnich dekad samorządy zostały znacząco wzmocnione zarówno finansowo, prawnie, jak i mentalnie - mają przepracowane schematy działań, które w chwili obecnej podlegają ewaluacji. Przekłada się to na realną możliwość dalszego rozwoju w oparciu o zdobyte doświadczenie.

\section{Bibliografia}

Babuchowska K., Kisiel R., Wptyw samorzadu gminnego na lokalny rozwój gospodarczy na przykładzie gmin województwa warmińsko-mazurskiego, „Acta Scientiarum Polonorum. Oeconomia” 2006, R. 5, z. 2, http://acta_oeconomia.sggw.pl/pdf/ASO 5 2 2006.pdf [dostęp: 8.03.2019].

Boć J., Jeżewski J. (red.), Administracja publiczna, Kolonia Limited, Wrocław 2004.

Górniak J., Mazur S. (red. nauk.), Zarzadzanie strategiczne rozwojem, Ministerstwo Rozwoju Regionalnego, Warszawa 2012.

Grzebyk M., Filip P., Rola zarządzania w funkcjonowaniu samorządu gminnego, „Nierówności Społeczne a Wzrost Gospodarczy” 2012, z. 29.

Hausner J., Zarządzanie publiczne, Scholar, Warszawa 2008.

${ }^{23}$ Ustawa o rewitalizacji. Praktyczny komentarz, Ministerstwo Rozwoju Regionalnego, Warszawa 2016.

${ }^{24}$ J. Rokita, Zarzadzanie strategiczne. Tworzenie i utrzymywanie przewagi konkurencyjnej, PWE, Warszawa 2005, s. 27.

${ }^{25}$ L. Kowalczyk, Zarzadzanie miastem, [w:] R. Brol (red.), Ekonomika i zarzadzanie miastem, Wydawnictwo Akademii Ekonomicznej im. Oskara Langego, Wrocław 2004. 
Huges O.E., Public Management and Administration. An Introduction, The Macmillan Press Ltd., London 1994.

Jasińska M., Wybrane obszary nowego zarządzania publicznego w sektorze samorzadowym w Polsce, „Zeszyty Naukowe Politechniki Częstochowskiej. Zarządzanie” 2015, nr 18, http:// www.zim.pcz.pl/znwz [dostęp: 8.03.2019].

Kaczmarek T., Gminny podział administracyjny w świetle 25 lat funkcjonowania samorzadu terytorialnego w Polsce, „Przegląd Politologiczny” 2016, R. 21, nr 1.

Kieres L., Europejska karta samorządu lokalnego w orzecznictwie Trybunału Konstytucyjnego, „Ruch Prawniczy, Ekonomiczny i Socjologiczny” 2015, R. LXXVII, z. 3.

Kowalczyk L., Zarzadzanie miastem, [w:] R. Brol (red.), Ekonomika i zarządzanie miastem, Wydawnictwo Akademii Ekonomicznej im. Oskara Langego, Wrocław 2004.

Kraś J., Reforma samorzadu terytorialnego jako jeden z kluczowych elementów reformy administracji publicznej w III RP, „Resovia Sacra. Studia Teologiczno-Filozoficzne Diecezji Rzeszowskiej" 2006, nr 13.

Marchewka-Bartkowiak K., Nowe zarządzanie publiczne, „Infos” 2014, nr 18(178).

Marks-Krzyszkowska M., Zarządzanie publiczne - istota $i$ wybrane koncepcje, „Acta Universitatis Lodziensis Folia Sociologica" 2016, nr 56.

Młodzik E., Założenia koncepcji New Public Management, „Współczesne Problemy Ekonomiczne" 2015, nr 11.

Musioł-Urbańczyk A., Metody wspomagające implementację strategii rozwoju jednostki samorzadu terytorialnego, „Zeszyty Naukowe Politechniki Śląskiej. Organizacja i Zarządzanie” 2015, z. 78, nr 1928.

Rokita J., Zarzadzanie strategiczne. Tworzenie i utrzymywanie przewagi konkurencyjnej, PWE, Warszawa 2005.

Schumpeter J., Teoria rozwoju gospodarczego, PWN, Warszawa 1960.

Teklak P., Obowiązywanie, wykładnia oraz realizacja przepisów Europejskiej Karty Samorząu Lokalnego w polskim porzadku prawnym, Uniwersytet Wrocławski, Studenckie Koło Naukowe Prawa Międzynarodowego i Europejskiego, http://www.bibliotekacyfrowa.pl/Content/42873/07 Piotr Tetlak.pdf [dostęp: 8.03.2019].

Ustawa o rewitalizacji. Praktyczny komentarz, Ministerstwo Rozwoju Regionalnego, Warszawa 2016.

Wilson R.H., Ward P.M., Spink P.K., Rodriguez V.E., Governance in the Americas: Decentralization, Democracy and Subnational Government in Brazil, Mexico and the USA, University of Notre Dame Press, Notre Dame 2016.

Zawicki M., Nowe zarządzanie publiczne, PWE, Warszawa 2011.

Ziółkowski M., Goleń M., Zarządzanie strategiczne rozwojem lokalnym, [w:] H. Sochacka-Krysiak (red.), Zarządzanie gospodarka i finansami gminy, Wydawnictwo SGH, Warszawa 2006.

Ziółkowski M., Strategiczne zarządzanie rozwojem gminy, „Ruch Prawniczy, Ekonomiczny i Socjologiczny" 2015, R. LXXVII, z. 1.

Ziółkowski M., Zarządzanie strategiczne w polskim samorządzie terytorialnym, [w:] A. Zalewski (red.), Nowe zarządzanie w polskim samorzadzie terytorialnym, Wydawnictwo SGH, Warszawa 2005. 
Żbikowski J., Konkurencyjność jednostek samorządu terytorialnego. Wybrane problemy, „Handel Wewnętrzny" 2015, nr 4(357).

\section{Streszczenie}

\section{Zarządzanie w sektorze publicznym - wybrane zagadnienia}

W artykule podjęto rozważania nad wykorzystywanymi obecnie zasobami i możliwościami zarządzania strategicznego na poziomie gminy jako jednej z podstawowych działalności administracji, mającej realny wpływ na rozwój ekonomiczno-społeczny. Zarządzanie strategiczne na szczeblu gminnym nie jest oczywistym procesem, musi on bowiem podlegać wielu adaptacjom i dostosowaniu do potrzeb lokalnej wspólnoty. Ma ono jednak ogromny wydźwięk w procedurach i działaniach współczesnych lokalnych samorządów - większość z nich nie mogłaby funkcjonować bez choćby śladowych działań strategicznych.

Słowa kluczowe: zarządzanie, samorząd terytorialny, konkurencyjność

\section{Summary}

\section{Management in the public sector - selected issues}

The article discusses the possibilities of strategic management at the level of the municipality as one of the basic activities of the administration that has a real impact on economic and social development. The article attempts to assess the evolution of strategic management at the local government level. Strategic management at the municipal level is not an obvious process. It responds to the needs of the local community. However, it impacts on the procedures and activities of contemporary local governments - most of which could not function without strategic measures.

Keywords: management, local government, competitiveness 
Mateusz Bodzek

Uniwersytet Pedagogiczny im. KEN w Krakowie

\section{Zielone i społecznie odpowiedzialne zamówienia publiczne jako narzẹdzie zrównoważonego rozwoju transportu publicznego}

\section{Wprowadzenie}

Nieustanne i dynamiczne zmiany zachodzące w systemach społeczno-ekonomicznych stawiają przed władzami jednostek samorządu terytorialnego coraz to nowe wyzwania, którym muszą sprostać. Samorząd obecnie nie jest już tylko jednostką wykonującą zadania administracyjne, ale staje się przede wszystkim miejscem tworzenia realiów makroekonomicznych. W nowej rzeczywistości miasta, bo na nich skupiam swoją uwagę, tak jak firmy zaczęły podlegać prawom rynku, zostały zmuszone do wzajemnej rywalizacji po to, by przyciągnąć i utrzymać inwestorów, zachęcać turystów oraz być pozytywnie postrzeganymi przez mieszkańców ${ }^{1}$.

W tym celu podejmują szereg działań o charakterze inwestycyjnym i prorozwojowym. Ponieważ wydatkują środki pochodzące z danin publicznych, zobligowane zostały przez ustawodawcę do wyłaniania wykonawców i dostawców usług w drodze zamówień publicznych. Początkowo jedynym lub dominującym kryterium decydującym o wyborze danej oferty było kryterium ceny. Wyłonieni w ten sposób wykonawcy nie zawsze mogli wywiązać się z przyjętych na siebie zobowiązań lub zdarzały się sytuacje, w których zrealizowane inwestycje były słabej jakości. Dlatego też 22 czerwca 2016 roku ustawodawca znowelizował ustawę Prawo zamówień publicznych (pzp), wymuszając na wielu zamawiających odejście

${ }^{1}$ E. Glińska, Zarządzanie procesem kształtowania wizerunku miasta wśród jego mieszkańców na przykładzie Zambrowa, Wydawnictwo Adam Marszałek, Toruń 2008, s. 7. 
od dyktatu kryterium ceny. Nie jest to jednak wymóg bezwzględny, ponieważ nie trzeba go dochować, o ile zostaną spełnione okoliczności wymienione w art. 91 ust. 2a ustawy pzp.

Obserwowany w ostatnich latach wzrost zainteresowania koncepcją CSR - społecznie odpowiedzialnego biznesu (ang. corporate social responsibility) nasuwa pytanie, czy nie należałoby w procesie zarządzania zrównoważonym rozwojem miasta uwzględnić zasad tej koncepcji. Odpowiedź na nie wydaje się niebywale trudna. W pierwszym odruchu pojawia się szereg wątpliwości. Na czoło wysuwa się pytanie o efektywność ekonomiczną realizowanych zadań. Wszak jednostki samorządu terytorialnego nie są organizacjami nastawionymi na generowanie zysku. Wręcz przeciwnie, to właśnie w administracji publicznej generowane są olbrzymie koszty funkcjonowania społeczeństwa. Tu też pracują i są obsługiwani obywatele i wreszcie tutaj wpływ na środowisko jest bardzo duży (choćby amortyzacje sprzętów, biurokracja i wszelkie decyzje dotyczące inwestycji). Wynika z tego, że w związku z charakterem podejmowanych przez JST zadań mamy spełnione trzy składowe koncepcji CSR, a mianowicie: interesariuszy zewnętrznych oraz interesariuszy wewnętrznych, wpływ na środowisko i koszty, jakie ponosi społeczeństwo. W artykule podjęta została próba odpowiedzi na pytanie, w jakim zakresie w ogłaszanych postępowaniach o udzielenie zamówienia publicznego stosowane są społeczne i ekologiczne kryteria wyłaniania wykonawców i dostawców.

\section{Zrównoważone zamówienia publiczne}

Rozpoczynając rozważania na temat zrównoważonych zamówień publicznych, należy zwrócić uwagę na fakt, iż nie ma obecnie jednej powszechnie obowiązującej definicji. Jedyną jak dotąd oficjalnie przyjętą definicją zrównoważonych zamówień publicznych jest ta, stosowana przez Program Środowiskowy Organizacji Narodów Zjednoczonych (UNEP). Punktem wyjścia w definicji UNEP jest idea zrównoważonego rozwoju, który wymaga od rządów i organizacji rozważenia w swoich działaniach aspektów społecznych, gospodarczych i środowiskowych. Zgodnie ze wskazaniami UNEP, stosując zasady zrównoważonego rozwoju do zamówień publicznych, pod pojęciem zrównoważone zamówienia publiczne należy rozumieć proces, w którym organizacje zaspokajają swoje potrzeby na towary, usługi, roboty budowlane w oparciu o stosunek jakości do ceny w całym cyklu życia, generując korzyści nie tylko dla organizacji, ale także dla społeczeństwa i gospodarki przy jednoczesnym minimalizowaniu szkód dla środowiska. Przez zrównoważone zamówienia publiczne należy zatem rozumieć taki sposób organizacji postępowań o udzielenie zamówienia publicznego, który uwzględnia tam, gdzie to możliwe, aspekty środowiskowe i społeczne, co przekłada się na charakter udzielanego zamówienia przy jednoczesnym zapewnieniu celowego, racjonalnego i oszczędnego wydatkowania środków publicznych. W definicji tej mieszczą się więc zarówno tzw. zielone zamówienia publiczne, jak i społeczne bądź inaczej - społecznie odpowiedzialne zamówienia publiczne. Pojęcia te zostały zdefiniowane w dokumentach opracowanych przez Komisję Europejską i funkcjonują w systemie zamówień publicznych ${ }^{2}$.

${ }^{2}$ Krajowy Plan Działań w zakresie zrównoważonych zamówień publicznych na lata 2017-2020, UZP, Warszawa 2017. 


\section{Zielone zamówienia publiczne}

Zgodnie z definicją wypracowaną przez Komisję Europejską zielone zamówienia publiczne GPP (ang. green public procurement) oznaczają proces, w ramach którego instytucje publiczne starają się uzyskać towary, usługi i roboty budowlane, których oddziaływanie na środowisko $\mathrm{w}$ trakcie ich cyklu życia jest mniejsze w porównaniu do towarów, usług i robót budowlanych o identycznym przeznaczeniu, jakie zostałyby zamówione w innym przypadku3.

Zielone zamówienia publiczne wskazane zostały w Strategii Bezpieczeństwo Energetyczne i Środowisko - perspektywa do 2020 r. jako jeden z instrumentów wspierających poprawę stanu środowiska. Strategia ta przewiduje stymulowanie wzrostu poziomu zielonych zamówień tak, aby połowa udzielanych zamówień publicznych miała charakter ekologiczny. $Z$ tego też względu należy kontynuować upowszechnianie zielonych zamówień poprzez zwiększanie świadomości urzędników i przedsiębiorców, związanej z postrzeganiem przyjaznych środowisku towarów i usług jako istotnych bodźców dla wzrostu konkurencyjności ${ }^{4}$.

Swoje miejsce GPP znalazły także w strategii Sprawne Państwo 2020. Wskazano w niej, iż w celu efektywnego gospodarowania zasobami rzeczowymi i finansowymi urzędy administracji publicznej winny położyć nacisk na upowszechnienie istniejących już rozwiązań prawnych dotyczących uwzględnienia aspektów ekologicznych (tzw. zielonych zamówień publicznych) w procedurach przetargowych, a także zwiększenie popytu urzędów administracji publicznej na innowacyjne produkty. W procesie udzielania zamówień publicznych w dużo szerszym stopniu powinny być wykorzystywane narzędzia elektroniczne. Ponadto podkreślono, iż zwiększenie liczby podmiotów legitymujących się zweryfikowanym systemem zarządzania środowiskiem, zwiększenie liczby podmiotów stosujących certyfikowane technologie środowiskowe, zwiększenie liczby krajowych produktów certyfikowanych oznakowaniem może przyczynić się do wzrostu odsetka zielonych zamówień publicznych ${ }^{5}$.

Zielone zamówienia publiczne przywołuje także Strategia Innowacyjności i Efektywności Gospodarki na lata 2012-2020 „Dynamiczna Polska” (SIEG). Dokonując charakterystyki gospodarki kraju, wskazano na niedostateczną efektywność wykorzystania zasobów naturalnych i surowców. Wśród instrumentów zaradczych, przyczyniających się do ograniczania energochłonności i materiałochłonności gospodarki wymienia się wykorzystanie w szerszym zakresie zielonych zamówień publicznych. Wartość rynku zamówień publicznych w Polsce jest dowodem na duży potencjał w tym obszarze oraz wskazuje na istotną rolę administracji publicznej w inicjowaniu i utrwalaniu zachowań proekologicznych, co umożliwi rozwój wyrobów i usług charakteryzujących się wysokimi standardami środowiskowymi i społecznymi ${ }^{6}$.

${ }^{3} 5$ Komunikat Komisji - Zamówienia publiczne na rzecz poprawy stanu środowiska, $\operatorname{KOM(2008)}$ 400, Bruksela 2008.

${ }^{4}$ Urząd Zamówień Publicznych, https://www.uzp.gov.pl [dostęp: 13.03.2019].

5 Strategia Sprawne Państwo 2020, M.P. 2013, poz. 136, s. 48.

6 Strategia Innowacyjności i Efektywności Gospodarki na lata 2012-2020 „Dynamiczna Polska”Załącznik do uchwały nr 7 Rady Ministrów z dnia 15 stycznia 2013 r., Ministerstwo Gospodarki, Warszawa 2013. 


\section{Społecznie odpowiedzialne zamówienia publiczne}

Społecznie odpowiedzialne zamówienia publiczne, zgodnie z definicją ukształtowaną w dokumentach Komisji Europejskiej, oznaczają zamówienia publiczne, w ramach których bierze się pod uwagę co najmniej jedną z następujących kwestii społecznych: możliwości zatrudnienia, godną pracę, zgodność z prawami społecznymi i z prawem do pracy, integrację społeczną (w tym także osób niepełnosprawnych), równość szans, dostępność i projektowanie dla wszystkich, uwzględnianie kryteriów zrównoważonego rozwoju, w tym kwestii etycznego handlu oraz szerszego dobrowolnego przestrzegania zasad społecznej odpowiedzialności biznesu (CSR), z jednoczesnym uwzględnieniem zasad ujętych w Traktacie o Unii Europejskiej oraz w dyrektywach dotyczących zamówień publicznych ${ }^{7}$.

Postulat szerszego stosowania klauzul społecznych w zamówieniach publicznych został ujęty w Strategii Rozwoju Kapitału Społecznego. Główne zaplanowane działania w ramach SRKS to m.in.: wsparcie edukacji przedstawicieli administracji publicznej i organizacji społecznych w zakresie lepszego wykorzystania istniejących instrumentów, zlecania zadań publicznych organizacjom obywatelskim, wypracowanie i upowszechnianie standardów realizowanych zadań publicznych oraz mechanizmów monitorowania świadczonych usług z udziałem obywateli, zmiany obowiązujących regulacji prawnych umożliwiające poszerzenie zakresu stosowania klauzul społecznych w zamówieniach publicznych. W związku z tym należy kontynuować działania edukacyjne i upowszechniające dotyczące praktycznego stosowania klauzul społecznych. Krajowy Plan Działań uszczegółowia zapisy zintegrowanych strategii rozwoju. Wskazuje podstawę prawną oraz proponuje konkretne działania służące realizacji celów Średniookresowej Strategii Rozwoju Kraju.

Sposób uwzględnienia aspektów społecznych w zamówieniach publicznych może mieć różną formę. O społecznym charakterze decyduje m.in. funkcjonalność przedmiotu zamówienia, ale również grupa beneficjentów, do których kierowane są zamawiane usługi i wyroby. W ramach zamówień publicznych można także określić wymagania o charakterze społecznym związane $\mathrm{z}$ realizacją zamówienia na przykład poprzez zobowiązanie wykonawców do zatrudnienia do realizacji zamówienia osób z określonych grup czy też doprecyzowanie formy zatrudnienia osób wykonujących wskazane czynności w ramach realizacji zamówienia. Dla realizacji celów społecznych prawnie dopuszczalne jest także ograniczenie kręgu wykonawców ubiegających się o zamówienie publiczne do podmiotów, których działalność obejmuje społeczną i zawodową integrację osób z grup społecznie marginalizowanych?

${ }^{7}$ Kwestie spoleczne w zakupach. Przewodnik dotyczacy uwzględniania kwestii spolecznych $w z a-$ mówieniach publicznych, Komisja Europejska, Bruksela 2011, s. 7, https://rownosc.info/media/uploads/ biblioteka/publikacje/kwestie-spoleczne-w-zamowieniach-podrecznik-ke.pdf [dostęp: 13.03.2019]

${ }^{8}$ Strategia Rozwoju Kapitału Społecznego 2020, M.P. 2013, poz. 378.

9 Krajowy Plan Działań w zakresie zrównoważonych zamówień publicznych na lata 2017-2020, dz. cyt., s. 9. 


\section{Zrównoważone zamówienia publiczne w Polsce}

W Polsce od 2013 roku, kiedy po raz pierwszy opracowany został Krajowy plan działań na rzecz zrównoważonych zamówień publicznych, analizowany jest udział postępowań o udzielenie zamówienia publicznego uwzględniających kryteria ekologiczne oraz społeczne w ogólnej liczbie ogłaszanych postępowań. Analizy tej dokonuje Urząd Zamówień Publicznych (UZP) w oparciu o coroczną informację składaną przez organy administracji publicznej. Urzędowi powierzono ponadto bardzo odpowiedzialną funkcję, a mianowicie koordynatora procesu upowszechniania ZZP.

W oparciu o Krajowy Plan Działań w latach 2013-2016 zrealizowano szereg przedsięwzięć o charakterze edukacyjnym, informacyjnym i promocyjnym, spośród których należy wskazać:

- 7 konferencji poświęconych tematyce społecznych i zielonych zamówień publicznych, w których wzięło udział 830 osób,

- 15 dedykowanych szkoleń poświęconych problematyce ZZP, w ramach których przeszkolono 600 urzędników biorących udział w przygotowaniu i przeprowadzaniu postępowań o udzielenie zamówień publicznych,

- działalność wydawniczą obejmującą publikację trzech pozycji poświęconych problematyce zrównoważonych zamówień publicznych,

- działalność informacyjną polegającą na udostępnieniu i ciągłym rozbudowywaniu zakładki dobre praktyki w serwisie internetowym UZP.

Efekty realizacji założeń Krajowego Planu Działań na rzecz zrównoważonych zamówień publicznych na lata 2013-2016, zgodnie z założeniami przyjętymi w tym dokumencie, mierzone były za pomocą określonych wskaźników, dla których przyjęto pewne poziomy stanowiące oczekiwaną wartość docelową. Analizując dane w tym zakresie, można stwierdzić, że w przypadku zdecydowanej większości wskaźników przyjętych w KPD uzyskano poziom docelowy zakładany do osiągnięcia na koniec 2016 roku, a w części z nich, na przykład w przypadku liczby osób przeszkolonych z zakresu ZZP, osiągnięte wyniki były wyższe niż zakładano. Nie udało się w pełni zrealizować przyjętych celów w zakresie poziomu uwzględniania aspektów społecznych i środowiskowych w zamówieniach publicznych. Rzeczywisty poziom realizacji wskaźnika w zakresie zielonych zamówień publicznych wyniósł 11,40 procent z zakładanych 20 procent, a w przypadku społecznie odpowiedzialnych zamówień - odpowiednio 4,08 procent z 10 procent.

Krajowy plan działań na rzecz zrównoważonych zamówień publicznych na lata 20172020 zakłada, że udział zielonych zamówień publicznych w całkowitej liczbie zamówień udzielonych przez polskich zamawiających w danym roku wynosił będzie co najmniej 25 procent, a udział społecznych zamówień publicznych osiągnie poziom co najmniej 12 procent.

Jak wynika z raportu opublikowanego przez prezesa UZP, w 2017 roku udział społecznych zamówień publicznych w ogólnej liczbie udzielonych wyniósł 17 procent, podczas gdy ich wartość w odniesieniu do łącznej wartości zamówień publicznych stanowiła 26 procent. Na wynik ten złożyło się 2257 zamawiających, którzy udzielili łącznie 24052 zamówień publicznych o łącznej wartości 42080960 339,09 zł (bez podatku od towarów i usług). 
W odniesieniu do zamówień uwzględniających proekologiczne kryteria oceny ofert sytuacja przedstawia się odmiennie. W analizowanym okresie tylko 344 zamawiających w 1212 udzielonych zamówieniach uwzględniło powyższe kryteria, co stanowiło zaledwie 1 procent wszystkich zamówień. Łączna wartość zielonych zamówień w 2017 roku wyniosła 3237075 405,76 zł (bez podatku VAT), co stanowi 2 procent ogólnej wartości wszystkich zamówień udzielonych w tym roku ${ }^{10}$.

Kryteria ekologiczne i społeczne najczęściej wykorzystywane były w ramach postępowań mających na celu dostawy środków transportu na potrzeby gminnych zakładów komunikacyjnych oraz w zamówieniach na usługi budowlane. Ma to bezpośredni związek z tym, iż zakupy te finansowane są w znacznej większości ze środków UE, która w ostatnich latach kładzie coraz większy nacisk na to, aby środki publiczne wydawane były w sposób odpowiedzialny zarówno pod względem społecznym, jak i środowiskowym.

\section{Kraków liderem zrównoważonych zamówień publicznych}

W latach 2013-2018 władze Krakowa w ramach Programu zrównoważonego rozwoju transportu publicznego dla gminy miejskiej Kraków oraz gmin sąsiadujących rozpoczęły proces modernizacji transportu zbiorowego. W ogłaszanych przez miasto zamówieniach na dostawy autobusów i tramwajów na potrzeby MPK S.A. zaczęto stosować zarówno klauzule społeczne, jak i ekologiczne. Pozwoliło to Krakowowi w stosunkowo krótkim czasie stać się liderem w ekologicznym transporcie. Zakup nowoczesnego taboru nie byłby możliwy bez współpracy miasta z województwem małopolskim w pozyskaniu środków z UE na dofinansowanie konkretnych działań. Wszystkie nabywane przez miasto autobusy i tramwaje są pojazdami niskopodłogowymi, wyposażonymi w klimatyzację, automaty biletowe oraz nowoczesny system informacji dynamicznej dla pasażera. Na pokładzie każdego z autobusów zamontowano porty ładowarki USB, dzięki którym w trakcie podróży pasażer może doładować tablet lub telefon.

Jako pierwsza gmina w Polsce miasto Kraków uruchomiło na swoim terenie regularną linię obsługiwaną przez autobusy elektryczne. Działa ona nieprzerwanie od 29 kwietnia 2014 roku. Obecnie Kraków posiada największą w kraju flotę autobusów zasilanych energią elektryczną, a w Europie ustępuje pod tym względem tylko czterem miastom. Wśród tych pojazdów znajdują się zarówno tradycyjne autobusy niskopodłogowe, jak i jedyne w Polsce przegubowe autobusy elektryczne. Pojazdy te nie wytwarzają żadnych zanieczyszczeń i całkowicie eliminują lokalną emisję spalin. Ich baterie mogą być ładowane na dwa sposoby: poprzez zamontowany na dachu pantograf w czasie postoju na pętli lub poprzez łącze typu plug-in podczas przebywania pojazdu w zajezdni.

W ramach Regionalnego Programu Operacyjnego dla Województwa Małopolskiego przypadającego na lata 2014-2020 Kraków planuje zakup 150 autobusów elektrycznych. Jego pełna realizacja spowoduje, że pojazdy bezemisyjne będą stanowić jedną trzecią krakowskiego taboru autobusowego.

\footnotetext{
${ }^{10}$ Sprawozdanie Prezesa Urzędu Zamówień Publicznych za rok 2017, UZP, Warszawa 2018.
} 
Decyzją włodarzy Krakowa miasto postanowiło przyłączyć się do rządowego programu E-bus mającego na celu rozwój elektromobilności w Polsce. W ramach tego programu planowany jest zakup dalszych 161 autobusów elektrycznych na potrzeby miejskiego przewoźnika.

Inwestycje w autobusy elektryczne wymusiły inwestycje w rozbudowę infrastruktury ładującej. W zajezdni autobusowej Wola Duchacka wybudowano 28 stanowisk ładowania typu plug-in, natomiast w zajezdni w Nowej Hucie powstała stacja transformatorowa ładowania baterii. W 2018 roku oddano ponadto pięć nowych stacji ładowania poprzez pantograf, trzy w centrum miasta przy ul. Konopnickiej, Piaszczystej i Pawiej i po jednej na zajezdni na Woli Duchackiej i Brożka.

Niektóre z autobusów elektrycznych wyposażone są w panele fotowoltaiczne. Miasto zakupiło ponadto kilka autobusów hybrydowych. W ramach budowy zrównoważonego systemu transportu publicznego przewoźnik miejski zaprzestał eksploatacji autobusów napędzanych silnikami spalinowymi spełniającymi normy poniżej normy EURO 6. Działania te mają na celu ograniczenie zużycia paliwa, a co za tym idzie - ograniczenie lokalnej emisji $\mathrm{CO}_{2} \mathrm{i}$ innych zanieczyszczeń emitowanych do środowiska naturalnego. Podjęty przez Kraków wysiłek inwestycyjny spowodował, że ma on obecnie najbardziej ekologiczny tabor autobusowy w kraju.

Analogicznie przedstawia się sytuacja w odniesieniu do taboru tramwajowego. Wszystkie nowe wagony krakowskiego MPK S.A. wyposażone są w system rekuperacji energii elektrycznej. Oznacza to, że są one zdolne odbierać energię elektryczną wytwarzaną podczas hamowania innych pojazdów komunikacji miejskiej i wykorzystać ją dla potrzeb kontynuowania własnej jazdy. Rekuperacja pozwala zaoszczędzić blisko $10 \mathrm{GWh}$ energii elektrycznej rocznie, a w konsekwencji znacząco ograniczyć emisję zanieczyszczeń do środowiska. Oprócz zakupów nowoczesnych wagonów miejski przewoźnik modernizuje posiadany tabor, dostosowując go do nowych wymagań. Poprzez wymianę systemu napędowego znacznie ogranicza się zużycie energii trakcyjnej.

MPK S.A. stale inwestuje w obiekty, w których stosuje się rozwiązania proekologiczne. Przykładem mogą być myjnie taboru wykorzystujące wodę deszczową. Funkcjonują one w systemie podwójnego obiegu zamkniętego, co pozwala ograniczyć o 80 procent zapotrzebowanie przedsiębiorstwa na wodę.

\section{Podsumowanie}

Uregulowania dotyczące zrównoważonych zamówień publicznych obecne są w polskim porządku prawnym od ponad pięciu lat. Pomimo licznych działań podejmowanych przez UZP, mających na celu wzrost wiedzy i świadomości urzędników o konieczności odejścia od dogmatu najniższej ceny jako dominującego kryterium rozstrzygnięcia postępowania o udzielenie zamówienia publicznego, poziom osiąganych przez zamawiających wskaźników stosowania prospołecznych i proekologicznych kryteriów oceny ofert przyjmuje wartości odbiegające od oczekiwanych. Nasuwa się więc pytanie o przyczyny takiego stanu rzeczy. Problem ten wymaga pogłębionej analizy i stanie się przedmiotem badań autora, których wyniki zostaną omówione w kolejnych opracowaniach. Należy zarazem podkre- 
ślić, że mamy też szereg pozytywnych przykładów stosowania założeń ZZP. Jak pokazuje przywołany przykład aglomeracji krakowskiej, przy odpowiednim poziomie determinacji władz i odrobinie dobrej woli u osób zatrudnionych w komórkach odpowiedzialnych za przygotowanie i przeprowadzanie postępowań o udzielenie zamówienia publicznego możliwe jest prowadzenie zrównoważonej polityki inwestycyjnej z wykorzystaniem kryteriów prospołecznych i proekologicznych w wyborze oferenta.

\section{Bibliografia}

5 Komunikat Komisji Europejskiej - Zamówienia publiczne na rzecz poprawy stanu środowiska, KOM(2008) 400, Bruksela 2008.

Adamczyk J., Koncepcja zrównoważonego rozwoju w zarządzaniu przedsiębiorstwem, Akademia Ekonomiczna w Krakowie, Kraków 2001.

Adamczyk J., Społeczna odpowiedzialność przedsiębiorstw. Teoria i praktyka, PWE, Warszawa 2009.

Glińska E., Zarzadzanie procesem kształtowania wizerunku miasta wśród jego mieszkańców na przykładzie Zambrowa, Wydawnictwo Adam Marszałek, Torun 2008.

Jeżowski P., Kategoria rozwoju zrównoważonego w naukach ekonomicznych, [w] P. Jeżowski (red.), Ekonomiczne problemy ochrony środowiska i rozwoju zrównoważonego $w$ XXI wieku, SGH, Warszawa 2007.

Krajowy Plan Działań w zakresie zrównoważonych zamówień publicznych na lata 2013-2016, UZP, Warszawa 2013.

Krajowy Plan Działań w zakresie zrównoważonych zamówień publicznych na lata 2017-2020, UZP, Warszawa 2017.

Kwestie społeczne w zakupach. Przewodnik dotyczacy uwzględniania kwestii społecznych w zamówieniach publicznych, Komisja Europejska, Bruksela 2011, https://rownosc.info/media/ uploads/biblioteka/publikacje/kwestie-spoleczne-w-zamowieniach-podrecznik-ke.pdf [dostęp: 13.03.2019].

Paszkiewicz A., Szadziewska A., Przejawy społecznej odpowiedzialności w działalności przedsiębiorstw, „Prace i Materiały Wydziału Zarządzania Uniwersytetu Gdańskiego” 2011, nr 1, t. 1.

Sprawozdanie Prezesa Urzędu Zamówień Publicznych za rok 2017, UZP, Warszawa 2018.

Strategia Innowacyjności i Efektywności Gospodarki na lata 2012-2020 „Dynamiczna Polska" - Załącznik do uchwały nr 7 Rady Ministrów z dnia 15 stycznia 2013 r., Ministerstwo Gospodarki, Warszawa 2013.

Strategia Rozwoju Kapitału Społecznego 2020, M.P. 2013, poz. 378.

Strategia Sprawne Państwo 2020, M.P. 2013, poz. 136.

Urząd Zamówień Publicznych, https://www.uzp.gov.pl [dostęp: 13.03.2019]. 


\section{Streszczenie}

\section{Zielone i społecznie odpowiedzialne zamówienia publiczne jako narzędzie zrównoważonego rozwoju transportu publicznego}

Koszty zamawianych przez administrację samorządową towarów i usług pochłaniają znaczną część ich budżetów. Staje się ona zatem istotnym konsumentem i graczem rynkowym. Troska o środowisko oraz wzrost świadomości obywateli powoduje, że przedstawiciele administracji publicznej zmuszeni zostali do prowadzenia społecznie odpowiedzialnej i proekologicznej polityki inwestycyjnej. Artykuł prezentuje ideę zrównoważonych zamówień publicznych jako narzędzia zrównoważonego rozwoju. Zaprezentowane zostały zmiany zachodzące w zamówieniach publicznych oraz aktualny stan prawny przedmiotowych zagadnień. Szczegółowo omówiono założenia zrównoważonych zamówień publicznych, a następnie analizie poddano poziom ich realizacji w kraju.

Słowa kluczowe: zielone zamówienie publiczne, społecznie odpowiedzialne zamówienia publiczne, zrównoważone zamówienia publiczne, CSR, zrównoważony rozwój

\section{Summary \\ Green and socially responsible public procurement as a tool for the sustainable development of public transport}

The costs of goods and services ordered by local government administration consume a significant part of their budgets. Thus, it becomes an important consumer and market player. Care for the environment and an increase in citizens' awareness means that public administration representatives have been forced to conduct a socially responsible and environmentally friendly investment policy. This article presents the idea of sustainable public procurement as a tool for sustainable development. The changes taking place in public procurement as well as the current legal status regarding the issues in question are outlined. The assumptions of sustainable public procurement are discussed in detail, and then the level of their implementation in the country is analysed.

Keywords: green public procurement, socially responsible public procurement, sustainable public procurement, CSR, sustainable development 
Marta Wysogląd

Fundacja Instytut Innowacji i Rozwoju Społecznego ANIMAR

\section{Realizacja Zintegrowanych Inwestycji Terytorialnych na obszarze aglomeracji jeleniogórskiej przez jednostki samorządu terytorialnego}

W świetle zmian zachodzących we współczesnej przestrzeni społeczno-gospodarczej istotne jest dążenie do poszukiwania optymalnych i efektywnych rozwiązań, których celem będzie dynamizacja procesów przyczyniających się do wzrostu jakości życia społeczności lokalnych, regionalnych. Skuteczność tych działań zależy od stworzenia przez samorządy solidnych podstaw infrastrukturalnych i instytucjonalnych, w których określone zostaną środki i narzędzia wsparcia. Aby założenia te mogły być spełnione, władze samorządowe powinny dążyć do zacieśniania współpracy i eliminacji konkurencji pomiędzy kooperującymi podmiotami, w szczególności w pozyskiwaniu środków unijnych. Perspektywa finansowa na lata 2014-2020 dała możliwość zastosowania w ramach środków unijnych nowego mechanizmu, który wspiera podejście terytorialne umożliwiające realizację zintegrowanych pakietów inwestycji w postaci Zintegrowanych Inwestycji Terytorialnych (ZIT).

Realizacja Zintegrowanych Inwestycji Terytorialnych w Polsce ma na celu:

- promowanie partnerskiego modelu współpracy różnych jednostek administracyjnych na miejskich obszarach funkcjonalnych,

- $\quad$ zwiększenie efektywności podejmowanych interwencji poprzez realizację zintegrowanych projektów odpowiadających w sposób kompleksowy na potrzeby i problemy miast i obszarów powiązanych z nimi funkcjonalnie,

\footnotetext{
${ }^{1}$ Zasady realizacji Zintegrowanych Inwestycji w Polsce, Ministerstwo Rozwoju Regionalnego, Warszawa 2013, s. 4, https://rpo.slaskie.pl/dokument/zasady_realizacji_it_w_polsce [dostęp: 11.10.2018]..
} 
- $\quad$ zwiększanie wpływu miast i obszarów powiązanych z nimi funkcjonalnie na kształt i sposób realizacji działań wspieranych na ich obszarze w ramach polityki spójności.

Celem artykułu jest określenie zróżnicowania wykorzystania środków w ramach Regionalnego Programu Operacyjnego Województwa Dolnośląskiego na lata 2014-2020 w ramach nowego mechanizmu Zintegrowanych Inwestycji Terytorialnych dla obszaru Aglomeracji Jeleniogórskiej przeznaczonych na podniesienie konkurencyjności, potencjału turystycznego regionu oraz jakości życia mieszkańców.

\section{ZIT jako narzẹdzie realizacji polityki spójności w województwie dolnośląskim}

Podejście terytorialne w polityce regionalnej umożliwia zastosowanie Zintegrowanych Inwestycji Terytorialnych do pobudzania rozwoju miejskich obszarów funkcjonalnych. Zakłada finansowanie zadań z zakresu ZIT środkami z RPO. Tym samym miasta i ich obszary funkcjonalne podlegają szczególnemu wsparciu, a ich regionalne znaczenie może wzrosnąć. Jednym z warunków realizacji wymiaru terytorialnego polityki rozwoju, w tym stosowania ZIT, jest formalne wyodrębnienie i powołanie w strukturze funkcjonalno-przestrzennej obszarów funkcjonalnych. ZIT zostały bowiem dedykowane obszarom funkcjonalnym, w szczególności miejskim. W Polsce wyznaczono cztery typy miejskich obszarów funkcjonalnych, ukształtowane wokół ośrodków²:

- $\quad$ wojewódzkich, w tym metropolitalnych,

- $\quad$ regionalnych, tj. miast niepełniących funkcji ośrodków wojewódzkich, ale pełniących ważne funkcje administracyjne, gospodarcze, społeczne, a także mających duży potencjał dla rozwoju z punktu widzenia celów polityki przestrzennego zagospodarowania kraju,

- $\quad$ subregionalnych, tj. miast liczących od 50 do 100 tys. mieszkańców, pełniących ważne funkcje w rozwoju społeczno-gospodarczym i przestrzennym województw,

- lokalnych, tj. miast liczących poniżej 50 tys. mieszkańców, koncentrujących funkcje gospodarcze i służących obszarom wiejskim swoim zapleczem usługowym.

Z przedstawionego wykazu wynika, że jednostkami centralnymi, spajającymi i integrującymi obszary funkcjonalne, są miasta o różnej wielkości potencjału ludzkiego oraz zróżnicowanym poziomie rozwoju, na różnym stopniu hierarchii funkcjonalnej. W praktyce polityki regionalnej ZIT są realizowane w przypadku obszarów funkcjonalnych, ukształtowanych wokół miast wojewódzkich i regionalnych. Wynika to z uprzywilejowanego sposobu finansowania zadań z zakresu ZIT poprzez zarezerwowanie środków na ten cel w regionalnych programach operacyjnych na lata 2014-2020 (RPO). Dwa najważniejsze warunki realizacji ZIT to bowiem przygotowanie strategii ZIT dla powołanych obszarów funkcjonalnych oraz przeznaczenie na realizację ZIT w regionie środków z podstawowej alokacji RPO (jako uzupełnienie środków pochodzących z rezerwy programowej) ${ }^{3}$.

${ }^{2}$ Koncepcja przestrzennego zagospodarowania kraju 2030 (KPZK 2030), Rada Ministrów, Warszawa 2011, s. 159, https://miir.bip.gov.pl/strategie-rozwoj-regionalny/17847 strategie.html [dostęp: 8.10.2018].

${ }^{3}$ E. Szafranek, Zintegrowane Inwestycje Terytorialne jako narzędzie wspierajace ksztaltowanie centrów rozwoju regionalnego, „Rozwój Regionalny i Polityka Regionalna” 2015, nr 32, s. 81-94. 
Warunkiem realizacji ZIT jest posiadanie strategicznego dokumentu, w którym określone są cele, zasady współpracy, kierunki rozwoju, najważniejsze działania oraz przedsięwzięcia do zrealizowania wynikające $\mathrm{z}$ analizy barier oraz potencjałów rozwojowych. Warunek ten spełnia strategia ZIT, która przygotowywana jest przez każdy związek ZIT. W ramach strategii proponuje się kluczowe przedsięwzięcia dla rozwoju danego regionu, których finansowanie będzie dokonywane w ramach danego programu operacyjnego (zarówno przez Europejski Fundusz Rozwoju Regionalnego, jak i Europejski Fundusz Społeczny) ${ }^{4}$.

Założeniem strategii realizacji ZIT jest to, że za przygotowanie projektów mają odpowiadać władze szczebla lokalnego, gdyż to one najlepiej znają lokalne uwarunkowania, a opracowane przez nie projekty będą najlepiej odpowiadać na ich potrzeby rozwojowe. Odpowiedzialność samorządów lokalnych za inwestowanie unijnych środków zostanie tym samym znacznie zwiększona. Przygotowywane projekty mają przyczyniać się do rozwoju obszarów ze sobą powiązanych. By ubiegać się o wsparcie, będą musiały zostać uprzednio wpisane do wspólnej strategii ZIT5 .

Partnerstwa miast i otaczających je gmin oraz władze województwa dolnośląskiego wspólnie ustaliły cele i opracowały inwestycje niezbędne do ich osiągnięcia. Formuła ta umożliwia wyjście poza sztywne granice administracyjne samorządów, co przełoży się na większe oddziaływanie realizowanych wspólnie przedsięwzięć. Samorządy chcące realizować projekty w trybie ZIT zawiązują partnerstwo (np. stowarzyszenie lub związek międzygminny) i przygotowują wspólną Strategię Zintegrowanych Inwestycji Terytorialnych. Na terenie województwa dolnośląskiego określone zostały następujące związki ZIT:

- Zintegrowane Inwestycje Terytorialne Wrocławskiego Obszaru Funkcjonalnego (ZIT WrOF),

- Zintegrowane Inwestycje Terytorialne Aglomeracji Wałbrzyskiej (ZIT AW),

- $\quad$ Zintegrowane Inwestycje Terytorialne Aglomeracji Jeleniogórskiej (ZIT AJ).

ZIT-y stanowią narzędzie selekcji i realizacji przedsięwzięć istotnych dla rozwoju regionu Dolnego Śląska w oparciu o współpracę wielu podmiotów, podejmowaną w ramach obszarów funkcjonalnych. Kluczową przesłanką zastosowania ZIT w programie operacyjnym jest przede wszystkim potrzeba realizacji wzajemnie zależnych i komplementarnych projektów.

\section{Charakterystyka Zintegrowanych Inwestycji Terytorialnych Aglomeracji Jeleniogórskiej}

Obszarem realizacji ZIT AJ jest obszar jednostek samorządu terytorialnego, które przystąpiły do Porozumienia w celu wspólnej realizacji ZIT. ZIT AJ został utworzony na podstawie Porozumienia z dnia 6 maja 2015 r. w sprawie powierzenia Miastu Jelenia Góra zarządzania Zintegrowanymi Inwestycjami Terytorialnymi Aglomeracji Jeleniogórskiej oraz zasad współpracy Stron Porozumienia przy programowaniu, wdrażaniu, finansowaniu,

\footnotetext{
${ }^{4}$ Zasady realizacji..., dz. cyt., s. 12.

5 M. Gwizda, M. Kosewska-Kwaśny, Sz. Żółciński (red.), Fundusze UE 2014-2020, Wydawnictwo C.H. Beck, Warszawa 2014, s. 99-100.
} 
ewaluacji, bieżącej obsłudze i rozliczeniach Zintegrowanych Inwestycji Terytorialnych Aglomeracji Jeleniogórskiej ${ }^{6}$.

W skład Aglomeracji Jeleniogórskiej wchodzi: 6 gmin miejskich, 5 gmin miejsko-wiejskich, 6 gmin wiejskich oraz 1 miasto na prawach powiatu. Powierzchnia AJ zajmuje $1515 \mathrm{~km}^{2}$, co stanowi 7,60 procent powierzchni województwa dolnośląskiego. Średnia gęstość zaludnienia w województwie dolnośląskim wynosi 146 osób na km², a w AJ 209,00 osób na $\mathrm{km}^{2}$. Obszary miejskie Aglomeracji stanowią 54,06 procent powierzchni Aglomeracji ${ }^{7}$. Obszar AJ częściowo położony jest w terenie górskim pasma Sudetów Zachodnich oraz w niewielkim stopniu Sudetów Środkowych. Lokalizację gmin miejskich, miejsko-wiejskich, wiejskich oraz miasta na prawach powiatu w paśmie Sudetów Zachodnich i Środkowych przedstawiono w tabeli 1.

Tabela 1. Obszar ZIT Aglomeracji Jeleniogórskiej w perspektywie finansowej 2014-2020

\begin{tabular}{|c|c|c|}
\hline Gmina & Rodzaj gminy & Położenie \\
\hline Jelenia Góra (miasto na prawach powiatu) & miasto na prawach powiatu & Kotlina Jeleniogórska, Karkonosze \\
\hline Janowice Wielkie & gmina wiejska & Góry Kaczawskie, Rudawy Janowickie \\
\hline Jeżów Sudecki & gmina wiejska & Góry Kaczawskie, Pogórze Izerskie \\
\hline Karpacz & gmina miejska & Karkonosze \\
\hline Kowary & gmina miejska & $\begin{array}{l}\text { Kotlina Jeleniogórska, Rudawy } \\
\text { Janowickie, Karkonosze }\end{array}$ \\
\hline Mysłakowice & gmina wiejska & Kotlina Jeleniogórska \\
\hline Piechowice & gmina miejska & Karkonosze, Góry Izerskie \\
\hline Podgórzyn & gmina wiejska & Karkonosze, Kotlina Jeleniogórska \\
\hline Stara Kamienica & gmina wiejska & Kotlina Jeleniogórska, Góry Izerskie \\
\hline Szklarska Poręba & gmina miejska & Góry Izerskie, Karkonosze \\
\hline Gryfów Śląski & gmina miejsko-wiejska & Pogórze Izerskie \\
\hline Lubomierz & gmina miejsko-wiejska & Pogórze Izerskie, Pogórze Kaczawskie \\
\hline Mirsk & gmina miejsko-wiejska & Pogórze Izerskie, Góry Izerskie \\
\hline Wleń & gmina miejsko-wiejska & Góry Kaczawskie \\
\hline Świerzawa & gmina miejsko-wiejska & Góry Kaczawskie \\
\hline Wojcieszów & gmina miejska & Góry Kaczawskie \\
\hline Złotoryja & gmina miejska & Góry Kaczawskie \\
\hline Pielgrzymka & gmina wiejska & poza obszarem Sudetów \\
\hline
\end{tabular}

Źródło: opracowanie własne na podstawie Strategia Zintegrowanych Inwestycji Terytorialnych Aglomeracji Jeleniogórskiej przyjęta przez Komitet Sterujący i zaakceptowana przez Prezydenta Miasta Jelenia Góra w dniu 22 września 2015 r.

${ }^{6}$ Porozumienie nr DEF-Z 987/2015 w sprawie powierzenia zadań w ramach instrumentu Zintegrowane Inwestycje Terytorialne Regionalnego Programu Operacyjnego Województwa Dolnośląskiego 2014-2020 przez Zarząd Województwa Dolnośląskiego - Miastu Jelenia Góra jako Instytucji Pośredniczącej z dnia 11.06.2015 r., s. 36-40.

7 Tamże, s. 45-46. 
Celem głównym Strategii ZIT Aglomeracji Jeleniogórskiej jest integracja obszaru AJ w spójny organizm wzmacniający swoją konkurencyjność poprzez rozwój dostępności komunikacyjnej i innowacyjnej przedsiębiorczości oraz potencjału turystycznego, przyrodniczego i kulturowego dla poprawy życia mieszkańców. Biorąc pod uwagę powyższe założenie, w Strategii ZIT AJ zidentyfikowano cztery wzajemnie ze sobą powiązane priorytety ${ }^{8}$ : - $\quad$ konkurencyjna i innowacyjna gospodarka AJ,

- $\quad$ zintegrowany obszar AJ,

- infrastruktura społeczności AJ,

- aktywna społeczność AJ.

W ramach tak sformułowanych priorytetów podejmowane będą działania mające na celu ich realizację. Biorąc pod uwagę powyższe założenia, można było stworzyć strukturę układu celu strategicznego ZIT AJ, celów szczegółowych ZIT AJ, priorytetów ZIT AJ i działań ZIT AJ niezbędnych dla ich wdrażania.

W okresie programowania w latach 2014-2020 każde województwo posiada swój program operacyjny stanowiący narzędzie realizacji polityki regionalnej, w ramach którego przyznawana jest pomoc poszczególnym regionom w Polsce. Za ich przygotowanie i zarządzanie odpowiedzialne były samorządy województw. W perspektywie finansowej 2014-2020 polskie samorządy zarządzają większą sumą środków unijnych niż w okresie programowania 2007-2013. To stawia przed jednostkami samorządu terytorialnego większe wyzwania zarówno w pozyskiwaniu środków, jak i realizacji planowanych przedsięwzięć.

W województwie dolnośląskim realizowany jest dwufunduszowy program (EFRR i EFS) o nazwie Regionalny Program Operacyjny Województwa Dolnośląskiego 2014-2020 (RPO WD 2014-2020). Na realizację Programu zostało przeznaczonych 2 252,59 mln euro z funduszy europejskich, w tym 1 618,91 mln ze środków EFRR oraz 633,63 mln euro ze środków EFS. Jest to kwota o około 35 procent większa od tej, którą Dolny Śląsk dysponował w latach 2007-2013 w ramach Regionalnego Programu Operacyjnego oraz komponentu regionalnego Programu Operacyjnego Kapitał Ludzki .

Celem głównym Regionalnego Programu Operacyjnego dla Województwa Dolnośląskiego na lata 2014-2020 jest wzrost konkurencyjności Dolnego Śląska zapewniający poprawę poziomu życia jego mieszkańców przy zachowaniu zasad zrównoważonego rozwoju. Istotna jest zatem poprawa jakości życia mieszkańców przy jednoczesnym poszanowaniu warunków środowiska przyrodniczego. Poprawa konkurencyjności regionu przez podniesienie poziomu gospodarczego i społecznego musi uwzględniać użytkowanie zasobów naturalnych zgodnie z zasadami ekorozwoju ${ }^{10}$.

Ponad 113 mln euro zostało zaplanowanych do wydatkowania dla jeleniogórskiego ZIT-u. Główne obszary, w które zainwestowane zostaną te pieniądze, to m.in.:

- gospodarka niskoemisyjna,

- edukacja,

${ }^{8}$ Strategia Zintegrowanych Inwestycji Terytorialnych Aglomeracji Jeleniogórskiej przyjęta przez Komitet Sterujący i zaakceptowana przez Prezydenta Miasta Jelenia Góra w dniu 22 września 2015 r.

${ }^{9}$ Szczegółowy Opis Osi Priorytetowych Regionalnego Programu Operacyjnego Województwa Dolnośląskiego 2014-2020 zatwierdzony Uchwałą nr 412/V/17 Zarządu Województwa Dolnośląskiego z dnia 27 lutego 2017 r., s. 28.

${ }^{10}$ Tamże, s. 126. 
- rozwój,

- przedsiębiorczość ${ }^{11}$.

Szczegółowy podział środków w ramach Regionalnego Programu Operacyjnego na lata 2014-2020 dla ZIT na poszczególne osie priorytetowe został przedstawiony w tabeli 2.

Tabela 2. Alokacja środków wspólnotowych w podziale na osie priorytetowe RPO WD 2014-2020 dla ZIT AJ

\begin{tabular}{|l|l|c|c|c|c|}
\hline Oś priorytetowa & \multicolumn{1}{|c|}{ Priorytet inwestycyjny } & $\begin{array}{c}\text { Kwota środków } \\
\text { unijnych (euro) }\end{array}$ & Źródło & $\begin{array}{c}\text { Kwota przyzna- } \\
\text { na w ramach } \\
\text { ZIT JG (euro) }\end{array}$ & $\begin{array}{c}\text { Procent alokacji ZIT AJ } \\
\text { w stosunku do ogólnej alo- } \\
\text { kacji RPO WD 2014-2020 }\end{array}$ \\
\hline $\begin{array}{l}\text { Oś priorytetowa } \\
\text { nr 1 }\end{array}$ & $\begin{array}{l}\text { Przedsiębiorstwa } \\
\text { i innowacje }\end{array}$ & 415546718 & EFRR & 7500000 & 1,8 \\
\hline $\begin{array}{l}\text { Oś priorytetowa } \\
\text { nr 2 }\end{array}$ & $\begin{array}{l}\text { Technologie informacyjno- } \\
\text {-komunikacyjne }\end{array}$ & 66386308 & EFRR & 4000000 & 6,0 \\
\hline $\begin{array}{l}\text { Oś priorytetowa } \\
\text { nr 3 }\end{array}$ & Gospodarka niskoemisyjna & 392347048 & EFRR & 28500000 & 7,3 \\
\hline $\begin{array}{l}\text { Oś priorytetowa } \\
\text { nr 4 }\end{array}$ & Środowisko i zasoby & 180030665 & EFRR & 15500000 & 8,1 \\
\hline $\begin{array}{l}\text { Oś priorytetowa } \\
\text { nr 5 }\end{array}$ & Transport & 340626305 & EFRR & 13000000 & 3,8 \\
\hline $\begin{array}{l}\text { Oś priorytetowa } \\
\text { nr 6 }\end{array}$ & $\begin{array}{l}\text { Infrastruktura spójności } \\
\text { społecznej }\end{array}$ & 163026832 & EFRR & 12500000 & 7,7 \\
\hline $\begin{array}{l}\text { Oś priorytetowa } \\
\text { nr 7 }\end{array}$ & Infrastruktura edukacyjna & 60952230 & EFRR & 6000000 & \\
\hline $\begin{array}{l}\text { Oś priorytetowa } \\
\text { nr 8 }\end{array}$ & Rynek pracy & 254323171 & EFS & 3180905 & 9,9 \\
\hline $\begin{array}{l}\text { Oś priorytetowa } \\
\text { nr 9 }\end{array}$ & Włączenie społeczne & 143926219 & EFS & 8614949 & 1,3 \\
\hline $\begin{array}{l}\text { Oś priorytetowa } \\
\text { nr 10 }\end{array}$ & Edukacja & 1561893 & EFS & 14579146 & 6,0 \\
\hline
\end{tabular}

Źródło: opracowanie własne na podstawie Szczegółowy Opis Osi Priorytetowych Regionalnego Programu Operacyjnego Województwa Dolnośląskiego 2014-2020 zatwierdzony Uchwałą nr 412N/17 Zarządu Województwa Dolnośląskiego $\mathrm{z}$ dnia 27 lutego $2017 \mathrm{r}$.

Dokonując analizy rozdysponowania funduszy unijnych dla ZIT AJ, można wskazać, iż największe środki przeznaczono na wspieranie projektów w priorytecie infrastruktura edukacyjna, tj. prawie 10 procent. Wynika to z faktu, iż innowacje i nakłady na działalność badawczo-rozwojową przyczyniają się do poprawy rozwoju gospodarczego Dolnego Śląska. Na rozwój edukacji skierowano 9,4 procent alokacji EFRR. Istotnym problemem obszaru AJ jest bowiem niedostosowanie poziomu i profilu wykształcenia do potrzeb rynku pracy. Już na poziomie szkoły podstawowej dzieci powinny mieć dostęp do nowoczesnych technologii, innowacyjnych metod nauczania wprowadzanych przez wyspecjalizowaną kadrę nauczycielską, co zwiększy ich potencjał oraz późniejsze szanse na rynku pracy. W poszczególnych gminach AJ dostrzega się nierównomierny rozkład możliwości korzystania przez uczniów z komputerów z dostępem do Internetu. Korzystnie na tym polu wygląda sytuacja w gminach wiejskich z małymi szkołami, jak gminy Podgórzyn, Jeżów Sudecki, Mysłakowice i Pielgrzymka, a wśród miast w gminie Lubomierz, w których przypada około 5 uczniów na jedno stanowisko. W pozostałych gminach wskaźnik ten jest jednak znacznie mniej ko-

\footnotetext{
${ }^{11}$ Porozumienie nr DEF-Z 987/2015..., dz. cyt., s. 35.
} 
rzystny, gdyż zwykle od 6 do 14 uczniów przypada na 1 komputer z dostępem do Internetu (a nawet do 20 uczniów w gminie Piechowice). Konieczne jest więc inwestowanie w edukację w celu poprawy warunków nauczania, zwłaszcza w zakresie zajęć matematyczno-przyrodniczych i cyfrowych, oraz przeznaczenie największej ilości środków w ramach RPO WD na tym obszarze ${ }^{12}$.

Równie istotna jest realizacja zadań związanych z ochroną środowiska naturalnego i bezpieczeństwa ekologicznego, szczególnie w odniesieniu do problemów związanych z zagospodarowaniem odpadów oraz ograniczeniem emisji substancji szkodliwych do środowiska. Konieczne jest podejmowanie przedsięwzięć mających na celu budowę, rozbudowę lub przebudowę infrastruktury chroniącej przed powodzią, suszą oraz innymi klęskami żywiołowymi, co przyczyni się do poprawy bezpieczeństwa mieszkańców regionu.

Uwzględniając podział środków EFRR pomiędzy poszczególne priorytety, należy zwrócić uwagę na znaczne nakłady (około 6 procent) na inwestycje w priorytetach technologie informacyjno-komunikacyjne oraz włączenie społeczne. Jest to podyktowane tym, że brak odpowiednich projektów w tym zakresie może spowodować barierę rozwoju regionu.

\section{Wykorzystanie środków w ramach RO WD na lata 2014-2020 przez jednostki samorządu terytorialnego}

Jednostki samorządu terytorialnego są istotnym i ważnym beneficjentem pomocy unijnej, dlatego też warunkiem prawidłowej realizacji zadań przez te jednostki jest właściwe zarządzanie finansami. Od jakości tego procesu zależy bowiem wynik gospodarowania posiadanymi zasobami w danych warunkach i otoczeniu ekonomicznym oraz poziom zaspokojenia potrzeb społeczności lokalnej. Środki będące w dyspozycji JST mogą być wykorzystywane w różny sposób, co powoduje, że posiadając takie same zasoby i działając w zbliżonych warunkach ekonomicznych, można uzyskiwać różne rezultaty. Warunkiem koniecznym realizacji zadań JST jest właściwe zarządzanie finansami przy wykorzystaniu współczesnej wiedzy z tego zakresu, w tym również możliwości wsparcia środkami unijnymi ${ }^{13}$. Zarządzający jednostkami dążą przede wszystkim do rozwiązania problemów dotyczących inwestowania. Wyzwaniem dla nich staje się umiejętność skutecznego i efektywnego inwestowania, które często zależy od właściwych decyzji władz regionalnych, wymaga integracji i uwzględnienia specyfiki publicznych przedsięwzięć inwestycyjnych ${ }^{14}$.

Rozwój samorządu uwarunkowany jest posiadaniem środków na sfinansowanie zadań inwestycyjnych. Wydatki majątkowe mogą być finansowane z różnych źródeł: $\mathrm{z}$ dochodów własnych, z dotacji celowych, pożyczek komunalnych. Ważnymi instrumentami finansowymi polityki regionalnej Unii Europejskiej, wpływającymi na wzrost i rozwój lokalny oraz

${ }^{12}$ Strategia Zintegrowanych Inwestycji Terytorialnych..., dz. cyt., s. 27.

${ }_{13} \mathrm{H}$. Wyrębek, Zarzadzanie finansami jednostek samorzadu terytorialnego na przykladzie gminy, „Zeszyty Naukowe Polityki Europejskiej. Finanse i Marketing” 2009, nr 4(53), s. 143.

${ }_{14}$ J. Łukomska-Szarek, Analiza potencjatu inwestycyjnego i poziomu samofinansowania samorząów gminnych w Polsce, „Prace Naukowe Uniwersytetu Ekonomicznego we Wrocławiu” 2011, nr 195, s. 196. 
wzrost konkurencyjności gmin, są fundusze UE ${ }^{15}$. Dla gmin zrzeszonych w Aglomeracji Jeleniogórskiej wielką szansą na rozwój zarówno gospodarczy, jak i społeczny są dotacje unijne. Wykorzystanie środków unijnych pozyskanych przez jednostki samorządu terytorialnego w obszarze ZIT AJ przedstawiono w tabeli 3.

Tabela 3. Dofinansowanie UE uzyskiwane przez jednostki samorządu terytorialnego w ramach RPO WD 2014-2020 w podziale na priorytety dla obszaru ZIT AJ

\begin{tabular}{|l|c|c|}
\hline \multicolumn{1}{|c|}{ Nazwa osi priorytetowej } & Wartość projektów (zł) & Dofinansowanie (zł) \\
\hline 10. Edukacja & 2285453 & 3370844 \\
\hline 2. Technologie informacyjno-komunikacyjne & 3968450 & 17694184 \\
\hline 3. Gospodarka niskoemisyjna & 29397829 & 15942715 \\
\hline 4. Środowisko i zasoby & 19619762 & 14036875 \\
\hline 6. Infrastruktura spójności społecznej & 15882505 & 12529212 \\
\hline 7. Infrastruktura edukacyjna & 14740250 & 2189402 \\
\hline 8. Rynek pracy & 2382953 & 67936414 \\
\hline Suma & 88277201 & 2017 \\
\hline
\end{tabular}

Źródło: opracowanie własne na podstawie danych z Centralnego Systemu Teleinformatycznego SL2014 (stan z 30.09.2018).

Przeprowadzona analiza finansowania przedsięwzięć w ramach poszczególnych priorytetów pokazuje, iż najwięcej dofinansowania uzyskują podmioty należące do sektora jednostek samorządu terytorialnego w zakresie gospodarki emisyjnej - prawie $18 \mathrm{mln}$ zł, ochrony środowiska - około 16 mln zł oraz infrastruktury spójności społecznej - 14 mln zł. Dużym zainteresowaniem cieszą się również realizowane projekty z zakresu edukacji ze względu na duże zapotrzebowanie w tym obszarze.

Środki w latach 2014-2020 przeznaczano nie tylko na badania naukowe, transport, ochronę środowiska i cyfryzację kraju, ale także na aktywizację zawodową i rozwój przedsiębiorczości. Ponadto bardzo istotnymi obszarami, na które została spożytkowana także znaczna część środków, były obszary włączenia społecznego oraz edukacji, zwłaszcza w kontekście kształcenia ustawicznego. Doświadczenia w pozyskiwaniu środków wynikające z realizacji perspektywy finansowej 2014-2020 pokazują, że gminy decydują się na realizację zadań własnych rozwiązujących najważniejsze problemy, z jakimi się zmagają. Ze względu na niewystarczającą ilość środków na zaspokajanie najpilniejszych potrzeb infrastrukturalnych jednostek samorządu terytorialnego zapotrzebowanie na tego typu wsparcie było bardzo zbliżone w okresie programowania 2007-2013. W tabeli 4 przedstawiono poziom wskaźnika absorpcji środków w ramach RPO WD 2014-2020 przez jednostki samorządu terytorialnego na obszarze ZIT AJ.

\footnotetext{
15 A. Kotoła, Wplyw wykorzystania funduszy unijnych na wzrost konkurencyjności gmin, „Studia i Prace Wydziału Nauk Ekonomicznych i Zarządzania Uniwersytetu Szczecińskiego” 2006, nr 25, s. 162.
} 
Tabela 4. Wskaźnik absorpcji środków unijnych w ramach RPO WD 2007-2013 przez jednostki samorządu terytorialnego w ZIT AJ

\begin{tabular}{|l|c|c|c|}
\hline \multicolumn{1}{|c|}{ Gmina - beneficjent } & Dofinansowanie $(z \nmid)$ & Dofinansowanie UE $(z \nmid)$ & Liczba realizowanych projektów \\
\hline Jelenia Góra & 1092614 & 928722 & 1 \\
\hline Jeżów Sudecki & 7138270 & 7138270 & 2 \\
\hline Kowary & 5412495 & 4801789 & 6 \\
\hline Lubomierz & 11341431 & 10397587 & 2 \\
\hline Mysłakowice & 9161435 & 9161435 & 2 \\
\hline Piechowice & 255191 & 225076 & 4 \\
\hline Podgórzyn & 9021490 & 9021490 & 11 \\
\hline Stara Kamienica & 4299080 & 4299080 & 32 \\
\hline Świerzawa & 20214408 & 20119647 & 4 \\
\hline Suma & 67936414 & 66093097 & 2 \\
\hline
\end{tabular}

Źródło: opracowanie własne na podstawie danych z Centralnego Systemu Teleinformatycznego SL2014 (stan z 30.09.2018).

Na realizację projektów dofinansowanych z RPO WD 2014-2020 na obszarze ZIT AJ zakontraktowano ponad 60 procent środków, uwzględniając realizację celów strategicznych. Z analizy terytorialnego rozkładu udzielonego wsparcia z UE w okresie 2014-2020 wynika, iż najwięcej środków pozyskała gmina Świerzawa, która wdrożyła aż 11 projektów spośród 32 o wartości pond 20 mln zł; na drugim miejscu uplasowała się gmina Lubomierz - ponad $11 \mathrm{mln}$ zł, a na trzecim gmina Mysłakowice.

\section{Podsumowanie}

Regionalny Program Operacyjny dla Województwa Dolnośląskiego 2014-2020 stał się ogromną szansą dla rozwoju poszczególnych powiatów i gmin Dolnego Śląska, w tym również z obszaru Aglomeracji Jeleniogórskiej. Większa część środków RPO WD została przekazana jednostkom samorządu terytorialnego na różnego rodzaju inicjatywy i przedsięwzięcia, które nie tylko mają na celu poprawę warunków życia społeczności lokalnej, ale również przyczyniają się do realizacji celów zawartych w RPO WD, Strategii ZIT AJ, a zatem także celów polityki spójności.

Środki pochodzące z unijnego budżetu nie są gotowym rozwiązaniem, gwarantującym pobudzenie rozwoju gospodarczego gminy, a nieodpowiednie ich ulokowanie może w konsekwencji generować zbyt wysokie koszty w stosunku do możliwości finansowych. Jednakże właściwe wykorzystanie funduszy europejskich, uwzględniające aktualne potrzeby i kondycję finansową gminy, a także długoletni plan rozwoju może bezpośrednio wpłynąć na przyspieszenie tempa rozwoju ekonomicznego i gospodarczego.

Dzięki Zintegrowanym Inwestycjom Terytorialnym możliwe stało się delegowanie części zadań dotyczących wdrażania programów na poziom lokalny albo subregionalny przede wszystkim władzom samorządowym, gwarantując tym samym ich zaangażowanie w przygotowanie oraz realizację programów. Jest to ogromna szansa dla poszczególnych 
regionów kraju, gdyż Zintegrowane Inwestycje Terytorialne będą w znacznie większym stopniu niż inne narzędzia polityki regionalnej UE dopasowane do ich potrzeb. Możliwy będzie efektywniejszy wzrost konkurencyjności i atrakcyjności regionów dzięki uwzględnieniu potrzeb każdego z miejskich obszarów funkcjonalnych i możliwości formułowania zintegrowanych odpowiedzi na zróżnicowane potrzeby terytorialne.

\section{Bibliografia}

Gwizda M., Kosewska-Kwaśny M., Żółciński Sz. (red.), Fundusze UE 2014-2020, Wydawnictwo C.H. Beck, Warszawa 2014.

Koncepcja przestrzennego zagospodarowania kraju 2030 (KPZK 2030), Rada Ministrów, Warszawa 2011, https://miir.bip.gov.pl/strategie-rozwoj-regionalny/17847 strategie.html [dostęp: 8.10.2018].

Kotoła A., Wplyw wykorzystania funduszy unijnych na wzrost konkurencyjności gmin, „Studia i Prace Wydziału Nauk Ekonomicznych i Zarządzania Uniwersytetu Szczecińskiego”2006, nr 25.

Łukomska-Szarek J., Analiza potencjału inwestycyjnego i poziomu samofinansowania samorzadów gminnych w Polsce, „Prace Naukowe Uniwersytetu Ekonomicznego we Wrocławiu” 2011, nr 195.

Porozumienie nr DEF-Z 987/2015 w sprawie powierzenia zadań w ramach instrumentu Zintegrowane Inwestycje Terytorialne Regionalnego Programu Operacyjnego Województwa Dolnośląskiego 2014-2020 przez Zarząd Województwa Dolnośląskiego - Miastu Jelenia Góra jako Instytucji Pośredniczącej z dnia 11.06.2015 r.

Strategia Zintegrowanych Inwestycji Terytorialnych Aglomeracji Jeleniogórskiej przyjęta przez Komitet Sterujący i zaakceptowana przez Prezydenta Miasta Jelenia Góra w dniu 22 września $2015 \mathrm{r}$.

Szafranek E., Zintegrowane Inwestycje Terytorialne jako narzędzie wspierajace kształtowanie centrów rozwoju regionalnego, „Rozwój Regionalny i Polityka Regionalna” 2015, nr 32.

Szczegółowy Opis Osi Priorytetowych Regionalnego Programu Operacyjnego Województwa Dolnośląskiego 2014-2020 zatwierdzony Uchwałą nr 412/V/17 Zarządu Województwa Dolnośląskiego z dnia 27 lutego 2017 r.

Wyrębek H., Zarządzanie finansami jednostek samorządu terytorialnego na przykladzie gminy, „Zeszyty Naukowe Polityki Europejskiej. Finanse i Marketing” 2009, nr 4(53).

Zasady realizacji Zintegrowanych Inwestycji w Polsce, Ministerstwo Rozwoju Regionalnego, Warszawa 2013, https://rpo.slaskie.pl/dokument/zasady_realizacji it_w polsce [dostęp: 11.10.2018].

\section{Streszczenie \\ Realizacja Zintegrowanych Inwestycji Terytorialnych na obszarze aglomeracji jeleniogórskiej przez jednostki samorządu terytorialnego}

W świetle zmian zachodzących we współczesnej przestrzeni społeczno-gospodarczej istotne jest dążenie do poszukiwania optymalnych i efektywnych rozwiązań, których celem będzie dynamizacja procesów przyczyniających się do wzrostu jakości życia 
społeczności lokalnych, regionalnych. Aby założenia te mogły być spełnione, władze samorządowe powinny dążyć do zacieśniania współpracy i eliminowania konkurencji pomiędzy kooperującymi podmiotami, w szczególności w pozyskiwaniu środków unijnych. Perspektywa finansowa na lata 2014-2020 dała możliwość zastosowania w ramach środków unijnych nowego mechanizmu, który wspiera podejście terytorialne umożliwiające realizację zintegrowanych pakietów inwestycji w postaci Zintegrowanych Inwestycji Terytorialnych (ZIT). Artykuł przedstawia stopień wykorzystania środków w ramach Regionalnego Programu Operacyjnego Województwa Dolnośląskiego na lata 2014-2020 w ramach nowego mechanizmu Zintegrowanych Inwestycji Terytorialnych dla Obszaru Aglomeracji Jeleniogórskiej przeznaczonych na podniesienie konkurencyjności, potencjału turystycznego regionu oraz jakości życia mieszkańców.

Słowa kluczowe: polityka regionalna, samorząd terytorialny, fundusze unijne

\section{Summary \\ Implementation of Integrated Territorial Investments in the area of the Jelenia Góra Agglomeration by local government units}

In the light of changes taking place in the contemporary socio-economic space, it is important to seek optimal and effective solutions that aim to invigorate processes contributing to the quality of life of local and regional communities. In order for these objectives to be met, local government authorities should strive to strengthen cooperation and eliminate competition between cooperating entities, in particular in obtaining EU funds. The financial perspective for the years 2014-2020 gave the opportunity to apply a new mechanism within the framework of EU funds, which supports the territorial approach enabling the implementation of integrated investment packages in the form of Integrated Territorial Investments (ITI). The article presents the utilisation rate of funds under the Regional Operational Program of the Lower Silesian Voivodship for the years 2014-2020 within the framework of the new mechanism of Integrated Territorial Investments for the Agglomeration Area intended to increase competitiveness, tourist potential of the region and the quality of life of residents.

Keywords: regional policy, local government, EU funds 
Piotr Kuźniak

Fundacja IMAGO

\section{Opieka wytchnieniowa - uwarunkowania rozwoju usług na poziomie lokalnym}

Celem artykułu jest przybliżenie znaczenia i roli usług opieki wytchnieniowej jako rozwiązania dla opiekunów osób zależnych, umożliwiających poprawę ich funkcjonowania $\mathrm{w}$ aspekcie społecznym, zawodowym i prywatnym, a także przedstawienie praktycznych rozwiązań możliwych do zastosowania w ramach krajowej polityki społecznej, zwłaszcza na poziomie samorządu.

W marcu 2013 roku razem z polską grupą odwiedziłem duński ośrodek wsparcia dla dzieci niepełnosprawnych Granbohus ${ }^{1}$. Wizyta była elementem naszych poszukiwań w obszarze asystentury dla klientów z niepełnosprawnościami, jedną z kilku, które odbyliśmy w tamtym czasie. Niespodziewanie dla nas okazało się, że nasze pojmowanie roli i zadań asystenta znacząco odbiega od koncepcji będącej fundamentem działania ośrodka. Po pierwsze, nietypowa jak na nasze pojmowanie asystentury była grupa klientów Granbohus, tj. dzieci z niepełnosprawnościami czy szerzej - zależne osoby z niepełnosprawnościami. A właściwie nie tyle one, ile ich rodzice i stali opiekunowie, bo to ich potrzeby miały tu pierwszorzędne znacznie przy decydowaniu o korzystaniu z usług ośrodka. Po drugie, choć cała instytucja przypominała typową placówkę wsparcia, w której prowadzi się rehabilitację czy terapię, to przede wszystkim atmosfera była zupełnie domowa. Po trzecie i najważniejsze, celem istnienia tej instytucji samorządowej okazała się nie edukacja, rehabilitacja czy terapia, a zapewnienie rodzicom możliwości regeneracji sił, swoistej krótkiej przerwy regeneracyjnej, która umożliwiłaby im lepsze codzienne funkcjonowanie jako rodzic, partner, pracownik, człowiek. Oczywiście w tym samym Granbohusie odbywają się typowe zajęcia dla dzieci z niepełnosprawnością, znane nam również z polskich ośrodków, a personel posiada profesjonalne przygotowanie, między innymi pedagogiczne, niemniej najważniejsze jest stworzenie

\footnotetext{
${ }^{1}$ Granbohus, www.granbohus.dk [dostęp: 14.03.2019].
} 
w tym miejscu warunków domowych, będących jednocześnie standardem organizacyjnym placówki, budujących zaufanie i poczucie bezpieczeństwa zarówno małych uczestników, jak i rodziców.

Byliśmy zaskoczeni! Wsparcie państwa realnie umożliwiające rodzicom prawo do odpoczynku od długotrwałej opieki? Dostrzeganie sensu w pozafinansowym wsparciu dla tych, którzy de facto na co dzień i przez lata są odpowiedzialni za sukces edukacyjny i zawodowy dziecka, a czasem za ich egzystencję? Stworzenie warunków niepełnosprawnym klientom do przebywania w swoim przyjaznym środowisku lokalnym, przy jednoczesnej profesjonalnej opiece instytucjonalnej? Krótka przerwa dla rodziców - 5 dni na miesiąc, 1 dzień w ciągu tygodnia, dłuższy pobyt w okresach urlopowych, organizacja dzieciom czasu wolnego...

Od tego czasu, w latach 2013-2018, miałem wielokrotnie styczność z tego typu usługami, różnie zresztą nazywanymi w różnych krajach - na przykład przerwa regeneracyjna, krótka przerwa, opieka wytchnieniowa - podczas wizyt studyjnych między innymi w Niemieckim Czerwonym Krzyżu w Wolfenbuttel, norweskiej Gminie Sandnes, a także w trakcie udziału w konferencjach Międzynarodowego Stowarzyszenia Usług Krótkiej Przerwy (International Short Break Association - ISBA2; 2014 - Wolfenbuttel, 2016 - Edynburg, 2018 - Reykjavik). Usługi ukierunkowane na prawo rodziców bądź opiekunów do lepszego bilansu całożyciowego mają w niektórych krajach długą tradycję, na przykład w Wielkiej Brytanii, USA, Danii. Występują w systemach zagranicznych w rozmaitych wariantach:

- placówkowych,

- $\quad$ świadczone w domu osoby z niepełnosprawnością przez asystentów,

- $\quad$ w formie organizacji czasu wolnego „na zewnątrz” dla grup osób,

- jako część budżetów indywidualnych,

- $\quad$ w ramach programów krótkiej przerwy realizowanych w prywatnych domach, w formie zbliżonej do systemu rodzin zastępczych,

- $\quad$ skierowane do seniorów, osób z demencją bądź innymi chorobami przewlekłymi, ponieważ ich opiekunowie są narażeni na te same negatywne zjawiska wynikające z długotrwałej opieki (przemęczenie, ograniczenie zdolności do pełnienia innych ról społecznych, osamotnienie).

Cytując za prezydentem ISBA Donem Williamsonem: „80 procent usług typu asystenckiego jest realizowanych przez opiekunów, a tylko 20 procent przez specjalistów", co dobitnie podkreśla znaczenie wsparcia dla opiekunów. Tę konkluzję uzupełniają słowa prezeski Stowarzyszenia Orator, Lidii Lempart, która odpowiadając na pytanie, czego potrzebuje niepełnosprawne dziecko, mówi: „Matki i ojca w dobrej formie!”.

Czy w Polsce mamy stworzone warunki do zaspokajania tych potrzeb i czy istnieje świadomość praw rodziców i opiekunów do usług krótkiej przerwy w opiece? Powtarzające się protesty rodziców osób z niepełnosprawnościami, w tym te ostanie z maja 2018 roku, potwierdzają aktualność tezy, iż w Polsce konieczna jest polityka wspierająca opiekunów i usługi społeczne odpowiadające na ich potrzeby zaniedbywane od lat.

Rodziny - opiekunowie osób z niepełnosprawnościami na co dzień nie posiadają realnej systemowej alternatywy zaspokojenia swoich potrzeb, co dobitnie potwierdziły protesty ro-

\footnotetext{
${ }^{2}$ International Short Break Association, www.isba.me [dostęp: 14.03.2019].
} 
dziców między innymi przed gmachem parlamentu w 2014 roku, a także w maju 2018 roku. $\mathrm{Na}$ liście postulatów środowisk rodziców od lat pojawiają się te związane z wdrożeniem polityki wspierającej opiekunów w realizacji przez nich obowiązków opiekuna. Do tej pory w warunkach krajowych brak specjalistycznych rozwiązań tego typu - rozwiniętych polityk lokalnych i krajowych, a także sieci placówek, skoncentrowanych na realizacji praw osób do tzw. respite care - opieki wytchnieniowej jako podstawowego prawa (art. 19 Niezależne życie i włączenie w społeczeństwo; zwłaszcza lit. b: usługi wspierające, świadczone w społeczności lokalnej) $)^{3}$. Po raz pierwszy usługi opieki wytchnieniowej zostały wprost wpisane do rządowego programu „Za życiem” (2016) ${ }^{4}$, jednakże bez praktycznego wskazania dla samorządów w zakresie planowania i rozwoju tych usług. W rezultacie w warunkach krajowych mamy do czynienia ze zwiększającą się luką pomiędzy oczekiwaniami opiekunów a polityką na szczeblu lokalnym w zakresie zaspokojenia ich oczekiwań.

Według Społecznego Raportu Alternatywnego z wykonania Konwencji ONZ o prawach osób z niepełnosprawnościami (art. 28 Odpowiednie warunki życia i ochrona socjalna) system zabezpieczenia społecznego w Polsce nie promuje aktywnych postaw osób zależnych ani ich opiekunów, a jednocześnie system zniechęca do aktywności zawodowej ${ }^{5}$. W konsekwencji ta grupa osób oraz ich rodzin jest szczególnie narażona na ubóstwo - wskaźnik zagrożenia nim jest o 60 procent wyższy w przypadku gospodarstw domowych z osobami niepełnosprawnymi ${ }^{6}$. Zgodnie z cytowanym wyżej Społecznym Raportem Alternatywnym 80 procent środków w obszarze zabezpieczenia społecznego jednostki samorządu terytorialnego przeznaczają na świadczenia finansowe. Usługi i inna działalność finansowana jest z pozostałych 20 procent, co nie zaspokaja potrzeb w zakresie usług asystenckich i opiekuńczych. O ile dostrzega się już potrzebę wspierania profesjonalistów pracujących z osobami niepełnosprawnymi/niesamodzielnymi w związku z wypaleniem zawodowym, nie wdrożono w Polsce żadnych programów dotyczących wypalenia rodziców, będących wieloletnimi opiekunami. Raport Modele opieki nad osobami zależnymi ${ }^{7}$ stwierdza: „Obecnie największy ciężar opieki nad osobą niesamodzielną spoczywa jednak na rodzinie, która nie otrzymuje wystarczającego wsparcia w wypełnianiu funkcji opiekuńczych”.

Źródłem problemu jest systemowy brak mechanizmu skoordynowanego i wyspecjalizowanego wsparcia, skoncentrowanego na działaniach na rzecz opiekunów. Skuteczność dotychczasowych działań między innymi instytucji integracji społecznej nie powoduje znaczącej poprawy sytuacji społeczno-zawodowej wśród tej grupy. Poszczególne instrumenty wsparcia realizowane są bardzo często wskutek doraźnych działań, a nie zaplanowanych, skoncentrowanych na wspieraniu opiekuna procesach oddziaływania. Faktem jest nieproporcjonalnie większy nakład czasu i pracy opiekunów niż specjalistów świadczących usługi.

\footnotetext{
${ }^{3}$ Konwencja ONZ o prawach osób z niepełnosprawnościami, Dz.U. 2012, poz. 1169.

${ }^{4}$ Uchwała nr 160 Rady Ministrów z dnia 20 grudnia 2016 r. w sprawie programu kompleksowego wsparcia dla rodzin „Za życiem”, M.P. 2016, poz. 1250, s. 27.

5 Spoleczny raport alternatywny z realizacji Konwencji o prawach osób z niepetnosprawnościami w Polsce, Fundacja KSK, Warszawa 2015, s. 49.

${ }^{6}$ R. Szarfenberg, Ubóstwo i wykluczenie społeczne w Polsce - pomiar, wyjaśnianie, strategie przeciwdziałania, Uniwersytet Warszawski, Instytut Polityki Społecznej, Warszawa 2012, s. 24.

7 Z. Szweda-Lewandowska, Modele opieki nad osobami zależnymi, Uniwersytet Łódzki, Łódź 2014, s. 222 .
} 
Jednocześnie na poziomie samorządu, ale także na szczeblu krajowym, brakuje instrumentów/polityk zapewniających lepszy bilans całożyciowy, a jednocześnie podtrzymujących w roli opiekuna w dłuższym okresie.

Jak podaje Raport z ilościowych badań reprezentatywnych $w$ ramach projektu „,Konsultacje+ ”: „ograny publiczne wskazane były jako w dużym stopniu odpowiedzialne za wspieranie aktywności tych osób i ich rodzin, ale wyniki niniejszego sondażu sugerują, że działania te oceniane są jako nieskuteczne, co widać przede wszystkim w fakcie, że władze zarówno na poziomie samorządowym, jak również i rząd oraz organizacje przez niego powołane nie stanowią już w ocenie ankietowych głównego wsparcia dla osób z niepełnosprawnością i wymieniane są jedynie przez około jedną trzecią respondentów. Ponad 70 procent osób ankietowanych stwierdziło, że to przede wszystkim rodzina powinna wspierać osoby z niepełnosprawnością i dbać o ich społeczne włączanie. Zwraca to uwagę na fakt, że jakkolwiek długofalowe programy wsparcia są traktowane jako niezbędny element ze strony organizacji rządowych i pozarządowych, tak umożliwianie aktywnego życia na poziomie codziennej aktywności spoczywa w gestii najbliższych członków rodziny. Zatem jeśli organy państwa chcą wspierać osoby z niepełnosprawnością, powinny przede wszystkim adresować pomoc do ich najbliższego otoczenia"».

Zgodnie z Raportem z ewaluacji zewnętrznej finalnej wersji produktu innowacyjnego wypracowanego w ramach projektu Centrum Asystentury Społecznej (CAS) - model wsparcia zadań OPS/PCPR w aktywizacji społecznej i zawodowej ON, opracowanym w ramach projektu przez Bielskie Stowarzyszenie Artystyczne „Teatr Grodzki” i Fundację Imago9:

1. Na pytanie, które dotyczyło przekazywania obowiązków wcześniej należących do obowiązków rodziny, odciążenie stwierdziło 53,3 procent rodziców i 46,6 procent opiekunów.

2. Podsumowując odpowiedzi na pytania ewaluacyjne związane z otoczeniem niepełnosprawnych klientów, należy stwierdzić, że dobrze rozumieli oni rolę asystenta, a także zgodnie z założeniami dzięki usługom asystenckim członkowie rodziny zyskali także możliwość regeneracji sił.

Uruchomienie lokalnych polityk opieki wytchnieniowej pozwoliłoby samorządom zabezpieczyć kolejne ogniwo wsparcia nad osobami zależnymi, co pozwoli odpowiedzieć na potrzeby opiekunów. Konsultacje, warsztaty, konferencje, programy i działania eksperckie prowadzone przez fundację oraz Koalicję na rzecz usług asystenckich przy udziale osób decyzyjnych reprezentujących instytucje pomocy społecznej (kilkaset osób w okresie 2015-2018) potwierdzają potrzebę:

- pozyskania wiedzy na temat tworzenia lokalnych programów opieki wytchnieniowej, tj. wzorców rozwiązań i dobrych praktyk,

- $\quad$ uzupełnienia kwalifikacji personelu programującego nowe polityki wspierające opiekunów,

${ }^{8}$ M. Łuszczyńska, Raport z ilościowych badań reprezentatywnych w ramach projektu „,Konsultacje+”, Ministerstwo Rodziny, Pracy i Polityki Społecznej, Warszawa 2017, s. 118.

${ }^{9}$ M. Mike, Raport z ewaluacji zewnętrznej finalnej wersji produktu innowacyjnego wypracowanego w ramach projektu Centrum Asystentury Społecznej (CAS) - model wsparcia zadań OPS/PCPR w aktywizacji spotecznej i zawodowej ON, Bielskie Stowarzyszenie Artystyczne „Teatr Grodzki” i Fundacja Imago, Bielsko-Biała 2015, s. 23-25. 
- $\quad$ pozyskania nowych narzędzi i metod diagnozowania potrzeb lokalnego środowiska opiekunów,

- $\quad$ wprowadzenia modyfikacji w sposobie organizacji obecnie świadczonych usług.

Z pewnością istnieją w warunkach krajowych instytucje, które rolę wsparcia dla opiekunów częściowo pełnią, choć nie zostały do niej stworzone, na przykład: środowiskowe domy samopomocy, warsztaty terapii zajęciowej, turnusy rehabilitacyjne. Z pewnością mamy też profesjonalny personel przygotowany do świadczenia tego typu wsparcia na odpowiednim poziomie. Brak natomiast rozwiązań prawnych i praktycznych w tym zakresie, aby stworzyć stabilne warunki do ich rozwoju w perspektywie długofalowej, przede wszystkim na poziomie samorządu lokalnego.

Mimo to mamy już w Polsce przykłady uruchamiania programów krótkiej przerwy, tj. usług ukierunkowanych w sposób świadomy i celowy na prawo rodziców do przerwy wytchnieniowej. W roku 2015 poznańskie Stowarzyszenie Na Tak rozpoczęło działalność całodobową w tym zakresie, uruchamiając Dom Krótkiej Przerwy „Poranek”. Fundacja Imago od roku 2014 prowadzi we Wrocławiu program w oparciu o sieć asystentów, w ramach którego usługi są realizowane jako wsparcie w logistyce przemieszczania się, w domu klienta, organizacji czasu wolnego. Również Koła PSONI realizują od kilku lat działania z zakresu okresowego zastępstwa w opiece, w różnych formach organizacyjnych.

Obecne doświadczenia praktyczne, badawcze i eksperckie pozwalają już sformułować wstępne założenia dla rozwoju usług opieki wytchnieniowej, a także podjąć próbę zdefiniowania kluczowych pojęć:

I. Definicje:

1. Usługa opieki wytchnieniowej - usługa stwarzająca opiekunom faktycznym możliwość zaspokojenia potrzeb związanych z samorealizacją i funkcjonowaniem w rolach zawodowych i społecznych, wspierająca opiekuna faktycznego w realizacji jego roli opiekuna.

2. Opiekun faktyczny - osoba sprawująca opiekę nad osobą zależną (z którą najczęściej wspólnie zamieszkuje), doświadczająca długotrwałych obciążeń wynikających z tej opieki.

3. Osoba zależna - osoba z niepełnosprawnością lub osoba doświadczająca pokrewnych problemów wynikających z wieku i/lub choroby.

II. Cel: Celem usługi opieki wytchnieniowej jest zapewnienie opiekunom faktycznym wsparcia ze względu na obciążenia wynikające z opieki nad osobą zależną, a także realizacja prawa opiekunów faktycznych do samorealizacji w nawiązaniu do konwencji NZ o prawach osób z niepełnosprawnościami.

III. Możliwe korzyści wynikające z dostępu do usług:

1. Zapobieganie wypaleniu opiekunów i osób zależnych, odciążanie fizyczne i psychiczne opiekuna.

2. Pomoc opiekunowi w pełnieniu roli opiekuna oraz umożliwienie funkcjonowania w innych rolach życiowych.

3. Wzmacnianie deinstytucjonalizacji wsparcia, które w dużej mierze może być świadczone w formule środowiskowej.

4. Oferowanie osobom zależnym możliwości pełniejszego rozwoju i uczestnictwa w środowisku lokalnym lub poza nim. 
5. Umożliwienie osobom zależnym funkcjonowania w środowisku lokalnym.

6. Możliwość ograniczenia wydatków publicznych na wsparcie osób zależnych i ich opiekunów, zwłaszcza w odniesieniu do kosztów opieki instytucjonalnej i długoterminowej.

IV. Założenia wdrożeniowe usług na poziomie lokalnym:

1. Dostęp do usługi zdeterminowany długotrwałym obciążeniem opiekuna sprawowaniem opieki nad osobą zależną (niezależnie od dochodu).

2. Indywidualizacja usługi - określenie zakresu wsparcia na podstawie diagnozy potrzeb systemu rodzinnego, w tym oceny funkcjonowania osoby zależnej-decydująca rola diagnozy potrzeb, determinującej formę i zakres usług.

3. Dostęp do usługi niezależny od dochodu.

4. Pozostawienie samorządowi swobody określenia form organizacji usług przy jednoczesnej obligatoryjności usług. Możliwe formy:

- $\quad$ wsparcie całodobowe (połączone z noclegiem),

- wsparcie kilkugodzinne,

- wsparcie weekendowe,

- $\quad$ wsparcie w wyspecjalizowanej placówce,

- wsparcie w miejscu zamieszkania,

- $\quad$ wsparcie na zasadach homesharingu (rozwiązanie irlandzkiej organizacji Abillity West zbliżone charakterem do idei rodzin zastępczych) i programu shared lives (rozwiązanie brytyjskie, w ramach którego wsparcie jest realizowane na bazie zaplecza lokalowego osób prywatnych - profesjonalistów świadczących usługę),

- wsparcie interwencyjne.

5. Mechanizm finansowania usług łączący zróżnicowane źródła środków publicznych (samorządowych, budżetu państwa), w tym z uwzględnieniem częściowej odpłatności ze strony klientów.

6. Zapewnienie trwałości dostępu do usługi dla klientów (kontrakty na 3-5 lat).

7. Zapewnienie możliwości integrowania usług z innymi w ramach pakietu wsparcia.

8. Możliwość świadczenia wsparcia przez personel wybrany na podstawie profilu kompetencyjnego.

9. Zapewnienie wsparcia personelowi świadczącemu usługi (tj. poprzez superwizje, szkolenia).

Wszystko wskazuje na to, że w ostatnich latach w Polsce został zapoczątkowany proces zmierzający do stworzenia ram umożliwiających rozwój tych usług, a następnie stałe ich włączenie do systemu wsparcia. Inicjatywy organizacji pozarządowych, takich jak Fundacja Imago, Bielskie Stowarzyszenie Artystyczne „Teatr Grodzki”, Polskie Stowarzyszenie na rzecz Osób z Niepełnosprawnością Intelektualną, a także innych skupionych wokół powołanej w 2016 roku Koalicji na rzecz Usług Asystenckich, w połączeniu z możliwością finansowania tych usług w ramach regionalnych programów operacyjnych (środki Europejskiego Funduszu Społecznego) czy perspektywą wdrożenia rządowego programu „Za życiem”, zapoczątkują - mamy nadzieję już niebawem - realizację tej wyczekiwanej przez rodziców i opiekunów osób z niepełnosprawnościami, a także innych osób zależnych, formy wsparcia rodzin. 


\section{Bibliografia}

Granbohus, www.granbohus.dk [dostęp: 14.03.2019].

International Short Break Association, www.isba.me [dostęp: 14.03.2019].

Konwencja ONZ o prawach osób z niepełnosprawnościami, Dz.U. 2012, poz. 1169.

Łuszczyńska M., Raport z ilościowych badań reprezentatywnych w ramach projektu „, Konsultacje+", Ministerstwo Rodziny, Pracy i Polityki Społecznej, Warszawa 2017.

Mike M., Raport z ewaluacji zewnętrznej finalnej wersji produktu innowacyjnego wypracowanego w ramach projektu Centrum Asystentury Społecznej (CAS) - model wsparcia zadań OPS/ PCPR w aktywizacji społecznej i zawodowej ON, Bielskie Stowarzyszenie Artystyczne „Teatr Grodzki” i Fundacja Imago, Bielsko-Biała 2015.

Społeczny raport alternatywny z realizacji Konwencji o prawach osób z niepetnosprawnościami w Polsce, Fundacja KSK, Warszawa 2015.

Szarfenberg R., Ubóstwo i wykluczenie społeczne w Polsce - pomiar, wyjaśnianie, strategie przeciwdziałania, Uniwersytet Warszawski, Instytut Polityki Społecznej, Warszawa 2012.

Szweda-Lewandowska Z., Modele opieki nad osobami zależnymi, Uniwersytet Łódzki, Łódź 2014.

Uchwała nr 160 Rady Ministrów z dnia 20 grudnia 2016 r. w sprawie programu kompleksowego wsparcia dla rodzin „Za życiem”, M.P. 2016, poz. 1250.

\section{Streszczenie \\ Opieka wytchnieniowa - uwarunkowania rozwoju usług na poziomie lokalnym}

Artykuł przedstawia usługę opieki wytchnieniowej jako adekwatną odpowiedź na niezaspokojone potrzeby opiekunów osób zależnych w Polsce, jak również doświadczenia zagraniczne w tym zakresie. Stanowi próbę scharakteryzowania usług, omówienia sytuacji opiekunów, a także możliwości włączenia usług do krajowego systemu wsparcia osób z niepełnosprawnościami i ich rodzin.

Słowa kluczowe: opieka wytchnieniowa, krótka przerwa, usługi społeczne, samorząd, organizacje pozarządowe, opiekun, osoba z niepełnosprawnościami

\section{Summary \\ Respite care - determinants of the development of services at the local level}

The article presents respite care as an answer to the unmet needs of carers and the persons they care for in Poland, as well as foreign experiences in that field. It is an attempt to define the services mentioned above, to characterise the situation of carers and to present possibilities of how to include those services for persons with disabilities and their carers in the Polish support system.

Keywords: respite care, short break, social services, municipality, nongovernmental organization, carer, person with disability 


\section{ADMINISTRACJA SAMORZADDOWA W POLSCE - WYBRANE ASPEKTY}

Waldemar Janosiewicz Samorząd terytorialny w Polsce - zarys historyczny - Andrzej Piasecki, Paulina Rus Ekonomia społeczna w samorządzie terytorialnym - Sylwia Rapicka Pomówienie w polityce. Wybrane aspekty prawne i empiryczne - Emilia Szczęsna Unijne przepisy o ochronie danych osobowych w jednostkach samorządu terytorialnego - Jakub Olech Modele sądowej kontroli administracji - próba syntezy - Lilija Twardosz Wdrożenie przepisów UE dotyczących spraw spadkowych do porządku prawnego Rzeczypospolitej Polskiej • Małgorzata Kmak Kontrola administracji publicznej - ujęcie systemowe (wybrane aspekty) - Anna Janus Zarządzanie w sektorze publicznym wybrane zagadnienia - Mateusz Bodzek Zielone i społecznie odpowiedzialne zamówienia publiczne jako narzędzie zrównoważonego rozwoju transportu publicznego • Marta Wysogląd Realizacja Zintegrowanych Inwestycji Terytorialnych na obszarze Aglomeracji Jeleniogórskiej przez jednostki samorządu terytorialnego • Piotr Kuźniak Opieka wytchnieniowa - uwarunkowania rozwoju usług na poziomie lokalnym 